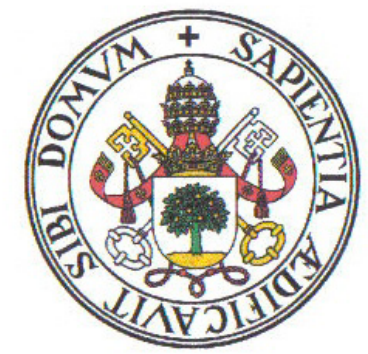

\title{
UniversidaddeValladolid
}

\author{
FACULTAD DE MEDICINA \\ DEPARTAMENTO DE CIRUGÍA
}

\section{TESIS DOCTORAL: \\ REGENERACIÓN ÓSEA MANDIBULAR MEDIANTE CULTIVO DE CÉLULAS MESENQUIMALES MANDIBULARES HUMANAS SOBRE MATRIZ PROTEICA OBTENIDA A PARTIR DE ALBÚMINA PLASMÁTICA: ESTUDIO EXPERIMENTAL DE INGENIERÍA TISULAR ÓSEA EN RATAS ATÍMICAS}

Presentada por Javier Antonio Fernández Doval para optar al grado de doctor por la Universidad de Valladolid.

Directores:

Dra. Ana Sánchez García

Dr. Carlos Vaquero Puerta

Codirectores:

Dr. Luís Miguel Redondo González

Dr. Alberto Verrier Hernández

Valladolid, 2015 




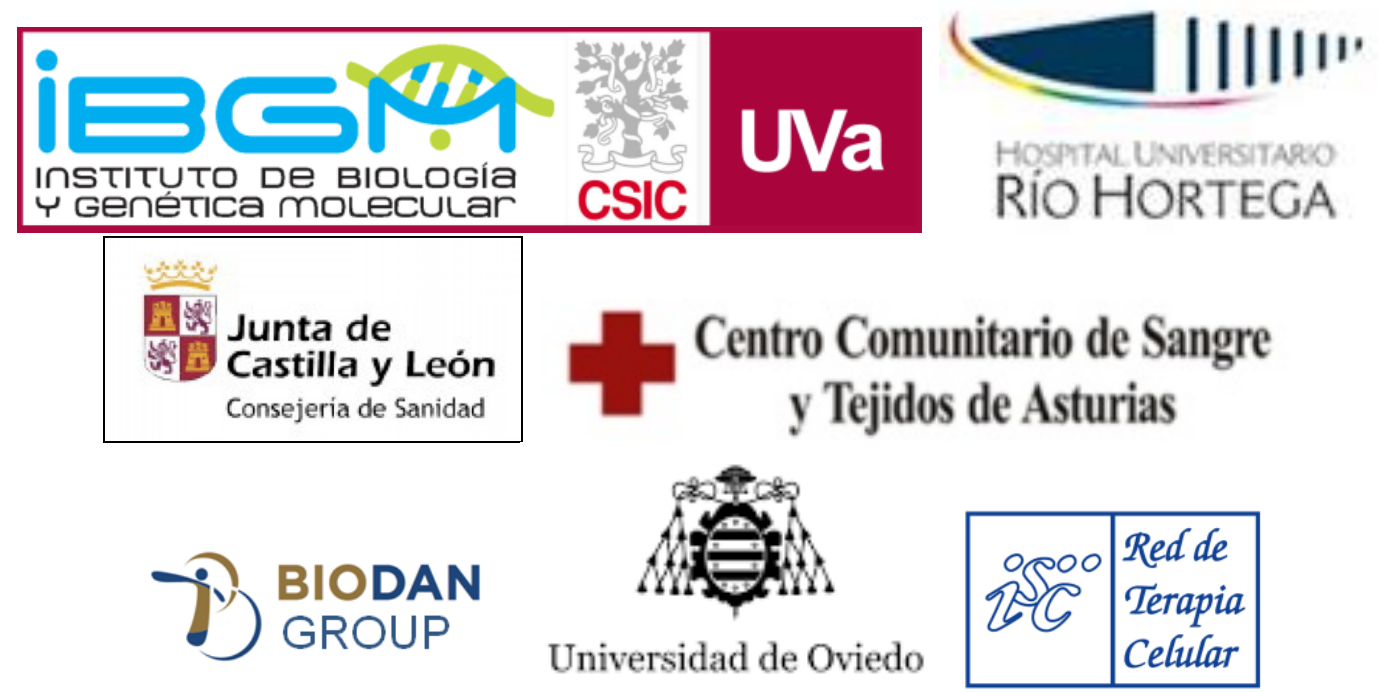






\section{AGRADECIMIENTOS}

A los directores de esta tesis, la Dra. Ana Sánchez García y el Dr. Carlos Vaquero Puerta, por su incesante labor investigadora.

A los codirectores, Dr. Luís Miguel Redondo González y Dr. Alberto Verrier Hernández, por sus innumerables enseñanzas en el campo de la medicina y en la vida en general. Por su amistad.

Al Dr. Ángel Álvarez García, responsable del Animalario de la Facultad de Medicina de la Universidad de Valladolid, por su dedicación y entrega en el cuidado y manipulación de los animales utilizados en este trabajo.

Al Dr. Manuel González Sagrado, responsable de la Unidad Investigadora del Hospital Río Hortega de Valladolid, por su colaboración en la interpretación estadística de los resultados obtenidos en este estudio.

Al Dr. Juan Manuel Oñate Cuchet y María Elena Pérez Martín, miembros del Servicio de Anatomía Patológica del Hospital Universitario Río Hortega de Valladolid, por su ayuda en la obtención e interpretación de los resultados histológicos.

A Verónica García Díaz, del Instituto de Biología y Genética Molecular, por su colaboración en el tratamiento, procesado y preparación de todas las muestras y materiales biológicos utilizados. 
Al Dr. Gonzalo de la Peña Varela, por su ayuda y tiempo compartido en la ejecución de este trabajo.

A Pablo, Nacho y Alfonso, por su apoyo incondicional. 
A mis padres, por su ejemplo y motivación continua.

A Sara, por todo. 

ABREVIATURAS 

ALP: Fosfatasa Alcalina

BMP: Bone Morphogenic Protein

BMPs: Proteínas Morfogenéticas Óseas

BMSC: Bone Marrow Stem Cells

Cbfa 1: Core-Bindingfactor A-1

CFU-F: Formadoras de Colonias de Fibroblastos

CFU-GM: Unidades Formadoras de Colonias de Granulocitos y Macrófagos

CLUT: Color Look-Up Tables

$\mathrm{Cm}$ : Centímetro

CV: Coeficiente de Variación

DE: Desviación Estándar

DER: Derecha

DICOM: Digital Imagning and Communications in Medicine

DMEM: Dulbecco'S Modified Eagles Medium

DMO: Densidad Mineral Ósea

EDTA: Etilén-Diamino-Tetra-Acético.

ESC: Embryonic Stem Cells

FBS: Suero Bovino Fetal

FDA: Food and Drug Administration

FGF: Factor de Crecimiento de Fibroblastos

FGF- $\beta$ : Factor de Crecimiento de Fibroblastos $\beta$

G-CSF: Factor Estimulador de Colonias de Granulocitos

G-CSF: Factor Estimulante de Colonias de Granulocitos

G: Gramo

GM CSF: Granulocitos Monocitos

H-E: Hematoxilina-Eosina 
$\mathrm{H}_{2} \mathrm{O}$ : Agua

HEPA: High Efficiency Particulate Air

Hg: Mercurio

IBGM: Instituto de Genética y Biología Molecular

IGF: Insulin-Like Growth Factor

Ihh: Indian Hedgehog

IPSC: Induced Pluripotent Cells

ITO: Ingeniería Tisular Ósea

IZQ: Izquierda

KDR: Factor de Crecimiento Vascular Endotelial

Kg: Kilogramo

M-CSF: Factor Estimulante de las Colonias de Macrófagos

MIP: Máximum Intensity Projection

Ml: Mililitro

Mm: Milímetro

MPR: Multi-Planar Reconstruction

MSC: Mesenchymal Stem Cells

NS: No Significativo

Nznu: New Zelland Nude Rats

ODF: Osteoclass Differentiation Factor

OPG: Osteoprogeterina

$\mathrm{P} / \mathrm{E}$ : Penicilina/Estreptomicina

PDGF: Factor de Crecimiento de Plaquetas

PDGF: Platelet-Derived Growth Factor

PGA: Ácido Poliglicólico

PLA: Ácido Poliláctico 
PTFE: Polímeros Fluorados

PTFE: Politetrafluoretileno

QCT: Quantitative Computed Tomography

RANK: Receptor Activator for Nuclear Factor Kappa-B

RANKL: Receptor Activator for Nuclear Factor Kappa-B Ligand

Rnu: Rowett Nude Rat

RGD: Arginina-Glicina-Ácido aspártico

ROI: Region of Interest

Rpm: Revoluciones por Minuto

RPMI: Roswell Park Memorial Institute Médium

Shh: Sonic Hedgehog

Sig: Significación

SM: Scaffold Meana

STBLINGS: Small Integrin-Binding Ligand, N-Linked Glycoprotein

TAC: Tomografía Axial Computerizada

TC: Tejido Conectivo

TCP: Tejido Conectivo Progenitor

TGF- $\beta$ : Factor Transformador del Crecimiento Beta

TGF: Transforming Growth Factor

TNF: Factor de Necrosis Tumoral

TNF: Tumoral Necrosis Factor

TRAP: Fosfatasa Ácido Tartrato Resistente

UDR: Unidades de Densidad Radiológica

VK: Von Kossa

VOI: Volumen of Interest 

ÍNDICE 



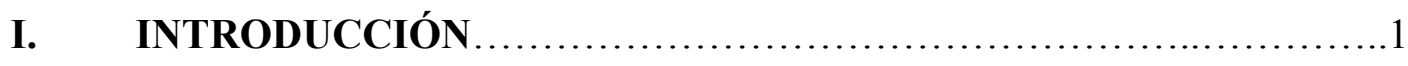

1. ESTRUCTURA ÓSEA: BIOLOGÍA DEL HUESO, ORIGEN, ESTRCTURA YCOMPOSICIÓN......................................

1.1 CÉLULAS ÓSEAS ..........................................

1.1.1 OSTEOBLASTO ..................................

1.1.2 OSTEOCITO $\ldots \ldots \ldots \ldots \ldots \ldots \ldots \ldots \ldots \ldots \ldots \ldots \ldots \ldots$

1.1.3OSTEOCLASTO ..................................

1.2 MATRIZ ORGÁNICA.........................................11

1.3 FASE MINERAL ................................................ 13

2. REGENERACIÓN ÓSEA..........................................14

2.1 FUNDAMENTOS.......................................... 14

2.1.1 OSTEOGÉNESIS..................................16

2.1.2 OSTEOINDUCCIÓN.............................17

2.1.3 OSTEOCONDUCCIÓN............................17

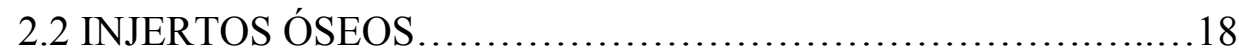

2.2.1 AUTOINJERTOS...............................18

2.2.2 ALOINJERTOS.............................19

2.2.3 XENOINJERTOS...............................19

2.2.3.1 CLASIFICACIÓN DE LOS

INJERTOS.................................20

2.3 MATERIALES SINTÉTICOS PARA LA

REGENERACIÓN ÓSEA...................................22 


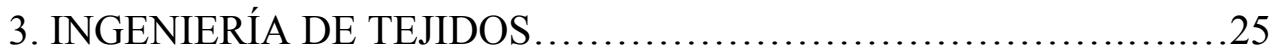

3.1 CELULAS MADRE ...........................................27

3.1.1 CELULAS MADRE EMBRIONARIAS ..........29

3.1.2 CELULAS MADRE ADULTAS.................30

3.1.3 ESTRATEGIAS DE INGENIERÍA TISULAR.....42

3.2 SOPORTE TRIDIMENSIONAL: SCAFFOLD ..................47

3.2.1 TIPO DE MATERIAL ............................48

3.2.2 ARQUITECTURA TRIDIMENSIONAL Y

POROSOSIDAD ...................................48

3.2.3 PROPIEDADES MECÁNICAS..................50

3.2.4 PROPIEDADES QUÍMICAS DE LA

SUPERFICIE ......................................52

3.3 FACTORES DE CRECIMIENTO ...............................54

II. JUSTIFICACIÓN, HIPÓTESIS Y OBJETIVOS ....................57

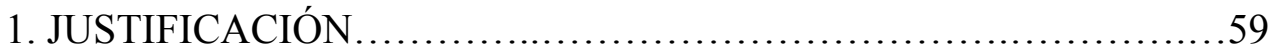

2. HIPÓTESIS .................................................60

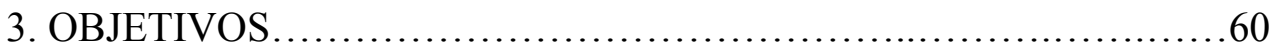

3.1 OBJETIVO GENERAL ........................................60

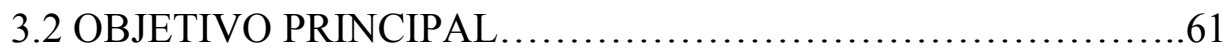

3.2 OBJETIVOS ESPECÍFICOS ................................62 


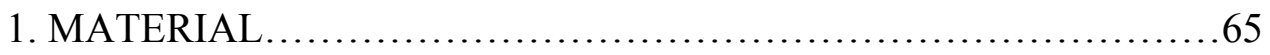

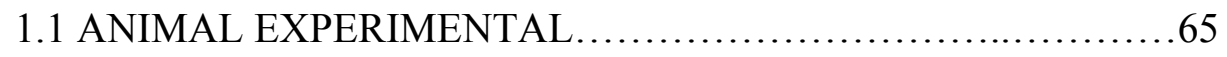

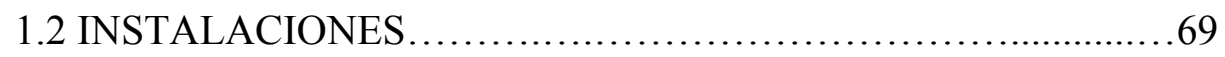

1.3 INSTRUMENTAL Y MATERIALES................................70

1.3.1 INSTRUMENTAL QUIRÚRGICO......................70

1.3.2 FÁRMACOS ........................................ 71

1.3.2.1 ANESTÉSICOS...................................71

1.3.2.2 FÁRMACOS POSTOPERATORIOS............71

1.3.3 MATERIAL PARA EL PROCESAMIENTO HISTOLÓGICO...............................71

1.3.4 PROCESAMIENTO DEL MATERIAL BIOLÓGICO.....72

1.3.5 MATERIAL PARA EL PROCESADO

RADIOLÓGICO …....................................73

1.3.6 MATERIAL PARA EL ESTUDIO ESTADÍSTICO........73

1.3.7 MATERIAL FOTOGRÁFICO..............................73

2. MÉTODO...............................................................

2.1 OBTENCION DE LAS MUESTRAS................................ 74

2.2 MANIPULACIÓN DE LAS MUESTRAS...........................76

2.3 PROCESAMIENTO DE LAS MUESTRAS...........................76

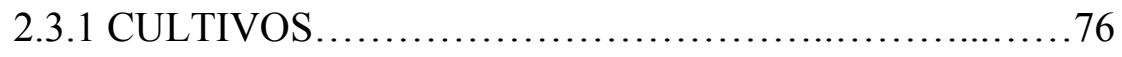

2.3.2 DESARROLLO DE LA MATRIZ PROTEICA..............77 
2.3.3 CULTIVO COMBINADO DE CÉLULAS Y MATRIZ.....78 2.4 FASE DE IMPLANTACIÓN DEL INJERTO.....................82

2.4.1 DISTRIBUCIÓN DE LOS GRUPOS.....................82

2.4.2 DESARROLLO DEL PROTOCOLO QUIRÚRGICO.....84 2.4.2.1 TÉCNICA ANESTÉSICA........................85

2.4.2.2 TÉCNICA QUIRÚRGICA......................85

2.4.2.2.1 ACTO QUIRÚRGICO

MANDIBULAR .................................85

2.4.2.2.2 ACTO QUIRÚRGICO INGUINAL......87

2.4.3 SEGUIMIENTO CLÍNICO Y CUIDADOS

POSTQUIRÚRGICOS..................................95

2.5 SACRIFICIO DE LOS ANIMALES ............................96

2.6 PROCESADO RADIOLÓGICO DE LAS MANDÍBULAS:

ESTUDIO EN TAC MULTICORTE.............................100

2.6.1 VALORACIÓN RADIOLÓGICA CUALITATIVA......100

2.6.2 VALORACIÓN RADIOLÓGICA CUANTITATIVA....101

2.7 PROCESADO HISTOLÓGICO DE LAS MUESTRAS:

VALORACIÓN MACROSCÓPICA Y MICROSCÓPICA............107

2.7.1 VALORACIÓN MACROSCÓPICA......................107

2.7.2 VALORACIÓN MICROSCÓPICA.......................108

2.8 ANÁLISIS ESTADÍSTICO.................................112

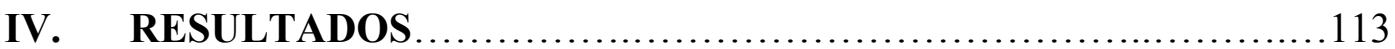

1. ESTUDIO ORTOTÓPICO.........................................115 
1.1 RESULTADOS RADIOLÓGICOS............................115

1.2 RESULTADOS HISTOLÓGICOS ..............................140

1.2.1 VALORACIÓN MACROSCÓPICA....................140

1.2.2 VALORACIÓN MICROSCÓPICA....................141

2. ESTUDIO HETEROTÓPICO: ESTUDIO DE LOS INJERTOS

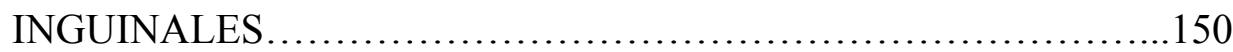

2.1 VALORACIÓN MACROSCÓPICA..........................150

2.2 VALORACIÓN MICROSCÓPICA.............................152

V. DISCUSIÓN ........................................................

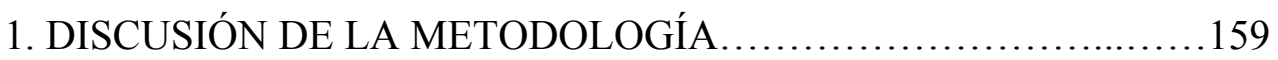

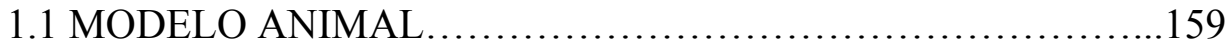

1.2 MODELO QUIRÚRGICO.................................161

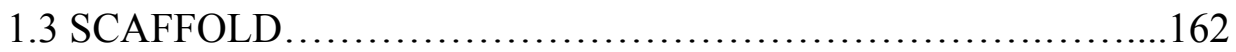

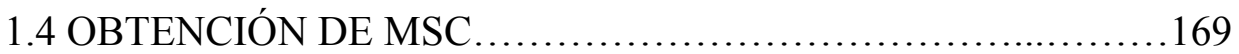

1.5 ANÁLISIS RADIOLÓGICO ................................170

2. DISCUSIÓN DE LOS RESULTADOS...............................175

VI. CONCLUSIONES .............................................. 183

VII. BIBLIOGRAFÍA .............................................. 187 



\section{INTRODUCCIÓN}





\section{ESTRUCTURA ÓSEA: BIOLOGIA DEL HUESO. ORIGEN, ESTRUCTURA Y COMPOSICIÓN.}

El hueso presenta una constitución físico-química, que le diferencia de otros tejidos del organismo, por su continua remodelación interna y sus capacidades regenerativas. Su origen embriológico es el tejido mesenquimal, dicho tejido sufre un proceso de osificación endocondral o intramembranoso (Marks y cols, 1988; Hall y cols, 1988):

- Los huesos de origen endocondral sufren un proceso denominado osificación indirecta o endocondral: las células mesenquimales se condensan y se diferencian en cartílago, el cual se hipertrofia, mineraliza y es invadido por vasos sanguíneos y células osteoprogenitoras. Los huesos de origen endocondral, como los huesos largos de las extremidades, columna vertebral y base del cráneo, mantienen porciones cartilaginosas como cartílagos articulares o de crecimiento. Se forma a partir de moldes de cartílago hialino que son parcialmente osificados (osificación indirecta o endocondral).

- Los huesos de origen membranoso se forman por osificación directa de las condensaciones mesenquimales, con la diferenciación directa de células mesenquimales a osteoblastos, sin que se produzca ninguna fase intermedia de osificación (osificación directa o intramembranosa). Los huesos que forman la bóveda craneal, el esqueleto facial y la clavícula son de origen membranoso, aunque alguno de ellos, como la mandíbula, occipital y temporal, tienen además centros de osificación endocondral.

El hueso es un tejido conectivo mineralizado, constituido por laminillas de matriz ósea

calcificada, (ilustración 1). Su disposición determinará que el hueso sea hueso cortical o hueso trabecular.

El hueso cortical o compacto constituye las láminas externa e interna de los huesos planos y la cobertura externa de los huesos largos. Su unidad básica es la osteona o 
sistema de Havers, formado por un canal longitudinal con uno o dos vasos sanguíneos y una lámina concéntrica de hueso en donde permanecen los osteocitos. A través de unos canales transversales, llamados canales de Volkman, los vasos sanguíneos alcanzan los canales de Havers y se anastomosan con el vaso que hay en su interior. Esta disposición es fundamental para la nutrición, ya que no es posible atravesar la matriz calcificada (Bloom y cols, 1994), y así los osteocitos se encuentran a menos de 300 micras de un vaso sanguíneo (Mathews y cols, 1980). Mediante los procesos de remodelación ósea se van formando nuevos sistemas de Havers y de forma simultanea los osteoclastos reabsorben el hueso viejo creando un nuevo túnel por donde elementos vasculares y osteoclastos migran y depositan nuevas láminas de hueso (Parfitt y cols, 1993).

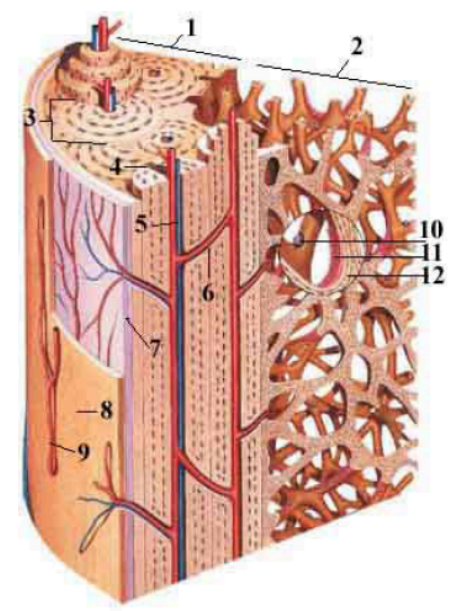

Ilustración 1. Esquema morfológico de la estructura ósea. 1: hueso cortical. 2: hueso trabecular. 3: sistema de Havers. 4: vaso sanguíneo. 5: canal de Havers. 6: Canal de Volkmann. 7: Periostio. 8: Revestimiento óseo. 9: Vasos del periostio. 10: Osteoclastos. 11: Osteblastos. 12: Osteocitos. (http://www.zonamedica.com.ar/categorias/medicinailustrada/osteoporosis/estructura.htm)

Su grosor varia según su localización en el esqueleto y de acuerdo al segmento de la diáfisis, y desde el punto de vista macroscópico este tipo de hueso cortical se divide en: plexiforme, haversiano y laminar (ilustración 2).

El hueso plexiforme está constituido por distintas capas de hueso fibrilar y hueso laminar, donde se encuentran localizados la mayoría de los canales vascularizados. 
El hueso haversiano es el más complejo de todos los tipos del hueso cortical. Está compuesto por canales vascularizados rodeado circunferencialmente por hueso laminar.

El hueso esponjoso o trabecular se encuentra situado entre las dos corticales de los huesos planos o en la metáfisis y epífisis de los huesos largos. Estructuralmente está compuesto por largas unidades de hueso llamadas trabéculas, en cuya superficie se localizan los osteoblastos. Estas trabéculas delimitan un sistema laberíntico ocupado por médula y vasos sanguíneos. La remodelación del hueso esponjoso se realiza en la superficie trabecular formando las llamadas lagunas de Howship, donde los osteoblastos depositan el nuevo hueso (Motoki y cols, 1990).

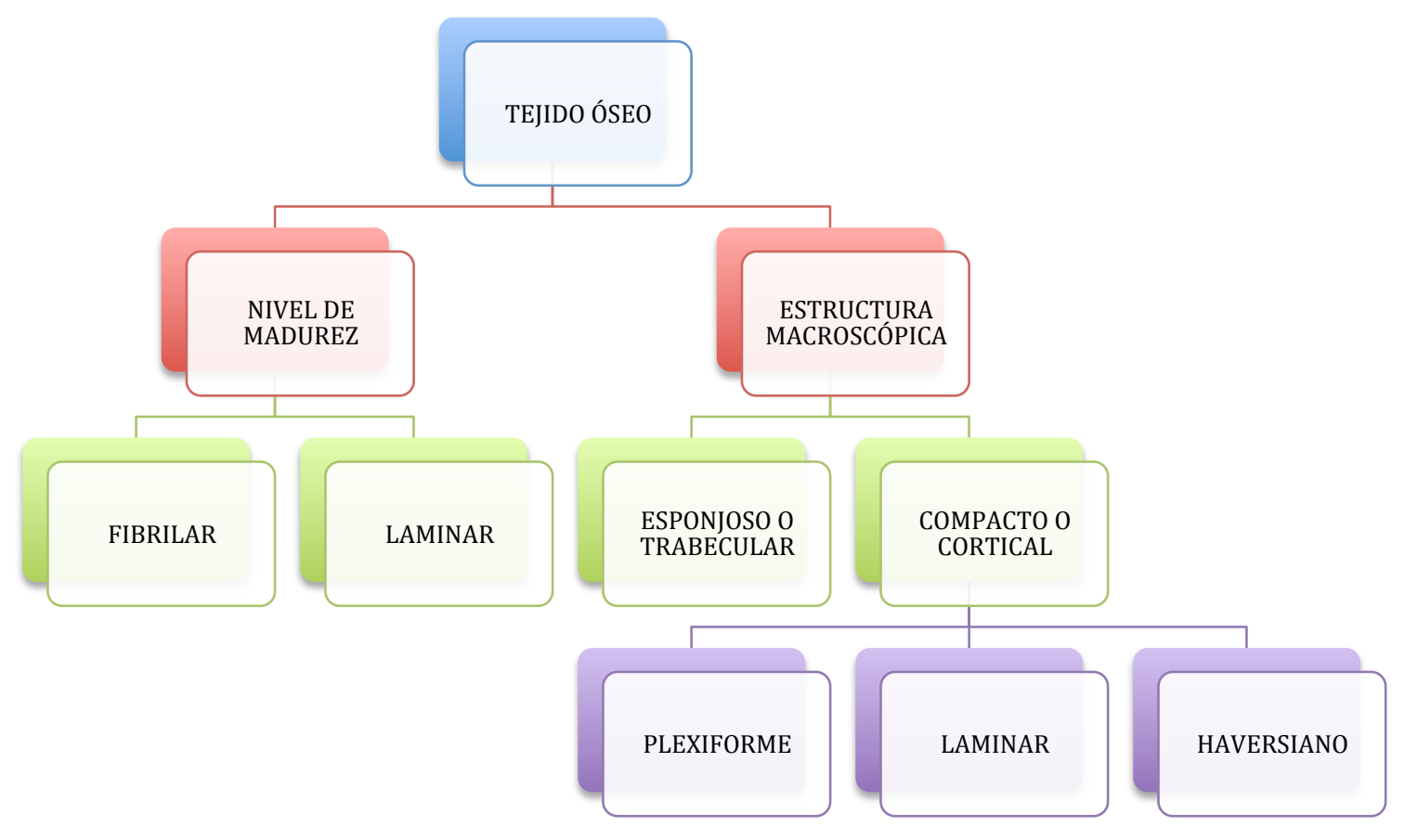

Ilustración 2. Esquema de los tipos de tejido óseo. 
Tanto el hueso cortical como el esponjoso está constituido por células óseas, matriz orgánica y fase mineral.

\subsection{CÉLULAS ÓSEAS}

Se hallan dentro del propio tejido óseo o en el estroma conjuntivo de la médula ósea, rico además en células mesenquimales (mesnchymal stem cells). Desde los trabajos de Friedenstein en 1976 se conoce que estas células dan origen a diferentes estirpes celulares como fibroblastos, osteoblastos, condroblastos, adipocitos y mioblastos, en función de las distintas señales moleculares que inician la cascada de activación de los diferentes genes (Harada y Rodan, 2003). La diferenciación hacia la estirpe osteoblástica está controlada por genes pertenecientes a la familia hedegehog, de los cuales los más conocidos son Ihh (Indian hedgehog) y Shh (Sonic hedgehog) (Yamaguchi y cols, 2000; Aubin y cols, 2000). También es esencial el factor de trascripción Cbfa 1 (core-bindingfactor a-1, también llamado Runx2 (Heersche y cols, 2002; Komori y cols, 1997; Ducy y cols, 1997; Hoschi y cols, 1999) y las proteínas morfogenéticas óseas (BMPs), que constituyen los reguladores más potentes de la diferenciación osteoblástica desde las células mesenquimales (Yamaguchi y cols, 2000). A medida que las células precursoras se van diferenciando, expresan en su membrana celular proteínas específicas de su función. La expresión de Cbfa 1 es la primera evidencia de la diferenciación osteogénica (Yamaguchi y cols, 2000), cuyo máximo nivel se alcanza en los preosteoblastos. El colágeno I y la osteopontina, se expresan de forma temprana en células osteoprogenitoras. Igualmente la fosfatasa alcalina $(A L P)$ es una proteína de superficie que podría participar en la regulación de la proliferación, migración y diferenciación de las células osteoblásticas. La sialoproteína ósea y la osteocalcina, son marcadores de diferenciación del pre-osteoblasto al osteoblasto y 
aparecen cuando se inicia la mineralización. La expresión de estas proteínas resulta especialmente útil como marcadores osteogénicos en los estadios finales de la diferenciación osteoblástica.

\subsubsection{OSTEOBLASTO}

El osteoblasto es una célula poliédrica con citoplasma basófilo y con un aparato de Golgi y un retículo endoplamático rugoso de gran tamaño. Estas células se pueden obtener a partir de células mesenquimales de la médula ósea, células del endostio, células del periostio y periocitos perivasculares (Canfield y cols, 2000). Los osteoblastos emiten procesos citoplasmáticos hacia la matriz, que comunican con la red de osteocitos y con osteoblastos vecinos. Los osteoblastos y osteocitos se comunican entre sí por proteínas transmembrana o integrinas, que actúan de enlace entre células o entre una célula y la matriz extracelular, permitiendo el paso de mensajeros como el calcio, citoquinas o prostaglandinas. En estas células la conexión intercelular es la conexina 43 (Civetelli y cols, 1993; Prêle y cols, 2003). Los osteoblastos sintetizan la matriz orgánica o sustancia osteoide a un ritmo de 2 a 3 micrómetros por día y expresan una enzima característica llamada fosfatasa alcalina, que permite la mineralización a un ritmo de 1-2 micrómetros por día.

Las funciones de estas células son (Manolagas y cols, 1995):

1. La síntesis de proteínas colágenas y no colágenas de la matriz orgánica del hueso.

2. La dirección de la disposición de las fibrillas de la matriz extracelular.

3. Mineralización de la sustancia osteoide, gracias a la fosfatasa alcalina.

4. Mediadores en la reabsorción llevada a cabo por los osteoclastos 
debido a la síntesis de citoquinas específicas.

5. Síntesis de factores de crecimiento.

La vida media de los osteoblastos humanos es de 1 a 10 semanas, al término de las cuales pueden desaparecer por mecanismos de apoptosis, transformarse en células limitantes o de revestimiento (bone lining cells) o en osteocitos (15\%) (Aubin y cols, 1996). Estos dos últimos tipos celulares representan estadios más avanzados de maduración. Las células limitantes son células elongadas y planas, con un núcleo en forma de huso, sin prácticamente ninguna clase de organela. Pueden expresar las proteínas y marcadores osteoblásticos anteriormente citados como sialoproteína ósea, osteopontina, osteonectina, fosfatasa alcalina, así como el receptor de parathormona (Masi y cols, 2001), que permanecen a lo largo de la superficie endóstica, constituyendo con el endostio, una capa protectora de la superficie ósea, que juega un papel importante en la activación del remodelado óseo.

\subsubsection{OSTEOCITO}

Una vez mineraliza la matriz, algunos osteoblastos quedan atrapados en su interior, transformándose en osteocitos. Los osteoblastos, osteoclastos y células limitantes se hallan en la superficie ósea, mientras que los osteocitos se encuentran en el interior. Los osteocitos son las células más abundantes del hueso, poseen una forma estrellada y su cuerpo se sitúa en el interior de las lagunas u osteoplasma y los procesos osteoplamáticos se comunican entre sí a través de los conductos calcóforos que están llenos de fluido óseo extracelular. De esta forma los osteocitos se organizan formando un sincitio de células interconectadas que representa una única estructura, con la ventaja de que existe una gran superficie de contacto en el interior y hacia la superficie ósea, para asegurarse oxígeno y nutrientes. Cuando se produce un trauma en el hueso, el cese 
de la circulación sanguínea genera hipoxia y necrosis de los osteocitos que se encuentren situados a más de $0.1 \mathrm{~mm}$ de un capilar intacto (Ham y cols, 1952).

La función principal del osteocito es la del remodelado óseo, detectando las variaciones mecánicas de las cargas (mecanotransducción) (Lanyon y cols, 1993) y manteniendo constante el equilibrio entre la fracción mineral y la orgánica. Los osteocitos constituyen el estadio final de la línea osteoblástica y son incapaces de renovarse. Los osteocitos expresan los mismos marcadores que los osteoblastos, pero tienen un marcador específico el $C D 44$, receptor de membrana que se expresa fuertemente en osteocitos y no existe en osteoblastos y células limitantes.

\subsubsection{OSTEOCLASTO}

Los osteoclastos son células grandes (100 micras), multinucleadas, ricas en mitocondrias y vacuolas, que contienen fosfatasa ácido tartrato resistente (TRAP) que permite la desfosforilación de las proteínas, actividad que es aprovechada para su identificación, tanto in vivo como in vitro. Además tienen receptores para la calcitonina.

Estas células proceden de células madre hematopoyéticas originadas a partir de las llamadas "Unidades Formadoras de Colonias de Granulocitos y Macrófagos" (CFUGM), que son las precursoras de macrófagos y monocitos (Mundy y cols, 1993).

Los osteoclastos tienen dos especializaciones en la membrana: un borde de cepillo, donde tiene lugar la reabsorción, y una zona clara, rica en microfilamentos, con integrinas que sirven de anclaje a la matriz. De este modo, los osteoclastos se movilizan hacia el área a reabsorber y seguidamente se adhieren a la superficie ósea mineralizada por el ribete en cepillo sellando los bordes del área mediante las integrinas (Masi y cols, 2001). La integrina del osteoclasto, especialmente la $a v \beta 3$, reconoce la secuencia ArgGly-Asp (RGD) existente en el colágeno y otras proteínas de la matriz osteoide. La 
secreción de ácidos $(\mathrm{H}+)$ generados por la anhidrasa carbónica II y enzimas proteolíticas como colagenasas, metaloproteasas, catepsina $K$, glucoronidasa... (Mundy y cols, 1993), van a originar la reabsorción del hueso mediante la solubilización de la matriz orgánica primero y de la mineral después. En la formación de los osteoclastos juegan un papel fundamental los osteoblastos. Así el factor estimulante de las colonias de macrófagos (M-CSF) producido por los osteoblastos es requerido en las primeras fases de la osteoclastogénesis para la formación de células gigantes multinucleadas (Baron ycols, 2003). Los osteoclastos se encuentran en regiones de reabsorción ósea llamadas lagunas de Howship. Los conocimientos actuales, acerca de la regulación de la osteoclastogénesis, se basan en la existencia de 3 moléculas: osteoprogeterina $(O P G)$, que es la proteína sintetizada por osteoblastos y pre-osteoblastos), RNKL (receptor activador de NFkB ligand), que es el ligando situado en la superficie de osteoblastos y pre-osteoblastos y $R A N K$, receptor del anterior situada en la membrana de osteoclastos y pre-osteoclastos. El RANKL también llamado $O D F$ (osteoclass differentiation factor) es una citoquina transmembrana perteneciente a la familia del factor de necrosis tumoral (TNF) (Lacey y cols, 1998). La interacción entre $R A N K L$ y su receptor $R A N K$ produce una activación de la diferenciación y de la actividad osteoclástica, aumentado la reabsorción. Asimismo los efectos del RANKL son inhibidos por la $O P G$, proteína circulante producida por los osteoblastos y preosteoblastos perteneciente a la superfamilia de los receptores de $T N F$. Cuando se unen $O P G$ y $R A N K L$ se inhibe la unión de $R A N K L$ a $R A N K$ y se inhibe la diferenciación osteoclástica. Por ello $O P G, R A N K$ y $R A N K L$ son importantes reguladores de la osteoclastogénesis. 


\subsection{MATRIZ ORGÁNICA}

La matriz orgánica se conoce también como sustancia osteoide y representa un tercio del peso óseo. Formada fundamentalmente por proteínas, (colágeno 90\%), la matriz juega un papel importante en el conjunto del sistema óseo, siendo evidente este hecho cuando aparecen enfermedades del colágeno como la osteogénesis imperfecta. Sin embargo, la matriz mineralizada extracelular constituye una reserva de proteínas que participan en la regulación de la diferenciación celular y en la integridad y función del tejido óseo (ilustración 3).

El colágeno representa el $90 \%$ de la matriz extracelular, especialmente el tipo I (95\%) y tipo V (5\%). También se ha comprobado la presencia, en pequeñas proporciones, de colágeno tipo III relacionado con las fibras de Sharpey y tipo XII, formado bajo estrés mecánico. En la molécula de colágeno se halla la secuencia Arg-Gly-Asp (RGD), que es reconocida por las integrinas de superficie de las células óseas (Gehron y cols, 1993). Contiene los aminoácidos hidroxilisina e hidroxiprolina, siendo este un marcador específico de todos los fenotipos de colágeno y estando sus valores de excreción urinaria en relación directa con la tasa de reabsorción ósea (Schonau y cols, 1997). Las fibras de colágeno se estabilizan mediante puentes de hidrógeno entre aminoácidos y a través de la formación de puentes de piridinolina, entre las hidroxilisinas y lisinas. Sin embargo el colágeno no tiene gran afinidad por el calcio, por lo que son otras las proteínas implicadas en el depósito mineral.

En la matriz orgánica nos podemos encontrar también proteínas no colágenas entre las que destacan:

- Proteoglicanos. Constituyen el 10\% de estas proteínas y son el hialurano y condroitín sulfato (intervienen fundamentalmente en las primeras fases de la 
morfogénesis ósea). Biglicano y decorina, que son moléculas más pequeñas y aparecen en las siguientes fases de formación ósea.

- Proteínas con ácido $\gamma$-carboxi-glutámico: Osteocalcina, que se sintetiza por los osteoblastos y plaquetas, dependiente de las vitaminas D y K. Representa el 15\% de las proteínas no colágenas de la matriz y contiene tres restos de ácido $\gamma$-carboxiglutámico. Sus niveles plasmáticos sirven de referencia como marcador bioquímico de la osteogénesis, relacionándose con el número y actividad de los osteoblastos; y la proteína de la matriz con ácido $\gamma$-carboxi-glutámico, que es un aminoácido que liga calcio y necesita la vitamina K para su síntesis.

- Glicoproteinas: osteonectina, que tiene afinidad por el colágeno tipo I, por el calcio y por la hidroxiapatita. Representan el $25 \%$ de las proteínas no colágenas e interviene en la adhesión celular entre la matriz y las células. La fosfatasa alcalina, que libera fosfato inorgánico a partir de ésteres fosfóricos, necesario para la mineralización. Existen varias isoenzimas, y entre ellas la ósea, se ha considerado un buen marcador de la actividad osteoblástica. También son glicoproteínas las proteínas con el tripéptido $R G D$, llamadas STBLINGS (Small Integrin-Binding Ligand, N-linked Glycoprotein) y son : osteopontina, sialoproteínas óseas, fibronectina, trombospondina y vitronectina, que son fundamentales en los procesos de remodelado y regeneración óseos, con una secuencia Arg-Gly-Asp (RGD), que son reconocidas por las integrinas de los osteoblastos y los osteoclastos. También actúan como receptores de la superficie de las células óseas, permitiendo la adhesión de las células a la matriz extracelular y activando señales.

- Proteínas procedentes del plasma: albúmina y $\alpha 2$-SH-glicoproteína. Relacionadas con la incorporación del calcio a la matriz osteoide.

- Factores de crecimiento. Son polipéptidos sintetizados en el propio hueso o procedentes de otros lugares (hígado, plaquetas...) e intervienen en la diferenciación, 
crecimiento y proliferación de las células de forma autocrina o paracrina (Canalis y cols, 2003).

\begin{tabular}{|c|c|}
\hline COLÁGENO & •Tipo I, III, V,XII \\
\hline PROTEOGLICANOS & $\begin{array}{l}\text { - Condroitín sulfato } \\
\text { - Decorina } \\
\text { - Biglicano } \\
\text { - Hialurano }\end{array}$ \\
\hline \multirow[t]{2}{*}{ PROTEINAS CON $\gamma$-CARBOXIi-GLUTÁMICO } & $\begin{array}{l}\text { - Osteocalcina } \\
\text {-Proteína de la matriz con ácido } \gamma \text {-carboxi-glutámico }\end{array}$ \\
\hline & $\begin{array}{l}\text { - Osteonectina } \\
\text { - Fosfatasa alcalina } \\
\text { - Proteínas con RGD: } \\
\text { - fibronectina } \\
\text { - trombospondina } \\
\text { - osteopontina } \\
\text { - vitronectina } \\
\text { - sialoproteínas óseas }\end{array}$ \\
\hline PROTEINAS DEL PLASMA & $\begin{array}{l}\text { •Albúmina } \\
\text { • } \alpha 2 \text {-SH-glicoproteína }\end{array}$ \\
\hline FACTORES DE CRECIMIENTO & $\begin{array}{l}- \text { IGF-I y II } \\
\cdot \text { TGF- } \beta \\
\cdot \text { PDFG }\end{array}$ \\
\hline
\end{tabular}

Ilustración 3. Resumen con los componente de la matriz osteoide.

\subsection{FASE MINERAL}

Representa el $65 \%$ del peso óseo, y está formado por calcio, fosfato y carbonato (en proporciones de 10:6:1) formando pequeños cristales de hidroxiapatita, con forma de aguja y estructura hexagonal de 2 a $7 \mathrm{~nm}$ de diámetro y de 5 a $10 \mathrm{~nm}$ de longitud. La cristalización y la proporción calcio/fósforo depende del tipo de hueso, ya sea esponjoso o cortical, y de la edad. También hay en menor proporción sodio, potasio, manganeso y flúor. Las propiedades mecánicas descritas para la hidroxiapatita son una densidad de 3219 g/cm3, un módulo elástico de 40 a 117 Gpa, una resistencia a la compresión de 294 a 917 Mpa y una resistencia a la tracción de entre 59 u 196 Mpa, por lo tanto 
presenta una mayor resistencia a la compresión que a la tracción. Las características de la fase mineral del tejido óseo dependen de su porosidad, que para el hueso cortical es proporcionada por los canales de Havers y Volkmann y las cavidades de reabsorción, que para el caso del hueso esponjoso es proporcionada por los espacios intertrabeculares. Las propiedades mecánicas del tejido óseo varían significativamente de acuerdo a su contenido de agua, existiendo un grado de hidratación crítica, ya que entre 37 y $48 \mathrm{mg}$ de $\mathrm{H}_{2} \mathrm{O} / \mathrm{g}$ de hueso, el agua puede liberarse de su ligadura a la estructura ósea.

Por tanto las fibras colágenas proporcionan flexibilidad y resistencia a la tensión al tejido óseo, mientras que las sales minerales le confieren dureza, rigidez y resistencia a la compresión. De hecho la estructura del hueso es muy similar a la del hormigón armado, en que las fibras colágenas realizan el papel del entramado de hierro y los minerales el papel funcional del hormigón.

\section{REGENERACIÓN ÓSEA}

\subsection{FUNDAMENTOS}

El hueso es un tejido dinámico, es decir está continuamente reemplazando sus células y su matriz, además de los procesos reparativos cuando tiene lugar una agresión ósea. Esta capacidad de reparación está influida por distintos mecanismos químicos, mecánicos, celulares, hormonales y patológicos.

Ante una agresión (ya sea a través de una fractura o por un procedimiento quirúrgico) se produce la formación de un coágulo de sangre, que conlleva la formación de un coágulo de fibrina que se mantiene hasta dos semanas. Se produce también la 
vasoconstricción de los vasos sanguíneos dañados durante esta agresión limitando la cantidad de sangre que entra en el tejido dañado. A continuación se produce la retracción del coágulo, lo cual produce la contracción de las fibras de fibrina en el coágulo. Debido a la cesión de la circulación, se produce una disminución muy importante del aporte de oxígeno, dando lugar a la necrosis del tejido circundante. Esto genera una serie de señales químicas que da lugar a la destrucción del coágulo y del tejido necrosado a través de un proceso de fagocitosis por medio de neutrófilos primero y posteriormente macrófagos.

A todo este proceso se le conoce con el nombre de hemostasis. A partir de este momento se produce una migración masiva de macrófagos al centro de la herida, produciéndose multitud de metabolitos y productos de degradación e incrementándose la demanda de oxígeno en el interior del coágulo donde todavía no se ha formado una vascularización suficiente, produciendo un aumento local de la concentración de lactato. Este aumento de lactato, unido al aumento de los ácidos y enzimas lisosomales liberadas durante la destrucción del tejido necrosado, disminuyen el pH del entorno. Se genera de esta manera, una señal quimiotáctica para un conjunto de células mesenquimales y endoteliales producida por la disminución en el gradiente de la concentración de oxígeno, dando lugar así a un proceso de angiogénesis. Esta angiogénesis da lugar a la desaparición del hematoma inicial y la aparición de un tejido fibroso vascularizado.

A partir de aquí comienza la migración de células osteogénicas produciéndose tracción en la matriz extracelular y generando una reorganización de la matriz fibrosa dando lugar a un colapso de las fibras de colágeno y fibrina, es decir una retracción de la herida.

Las células migrarán hasta alcanzar los márgenes del defecto óseo produciéndose en ese momento el proceso de síntesis de matriz extracelular en dicha superficie. Finalmente se 
inicia el proceso de mineralización a partir de las proteínas de la superficie, continuando así el crecimiento de cristales de fosfato de calcio y la unión de las capas de matriz de colágeno con capas mineralizadas dando como resultado la formación de hueso nuevo.

La regeneración ósea depende de distintos factores locales y sistémicos y sobre todo del tamaño del defecto a regenerar. Los defectos pequeños permiten la regeneración ósea directa o primaria. Este tipo de regeneración puede observarse en fracturas mecánicamente estables. Sin embargo, la inestabilidad mecánica y la pérdida de la vascularización son factores que determinan la reparación, produciéndose ésta mediante un proceso de osificación endocondral. (Schenk y cols, 1992; Johner y cols, 1972; Simmons y cols, 1985).

Los defectos óseos corticales y corticomedulares de un determinado tamaño, que superan un tamaño crítico (definido de forma distinta para cada tipo de hueso y especie animal), independientemente de poseer una buena estabilidad mecánica y un buen aporte sanguíneo, generan una reparación de tipo fibroso cicatrizal (Schmitz y Hollinger, 1986). Es por ello que la reparación de estos defectos críticos requiere inevitablemente el uso de técnicas y materiales capaces de promover el crecimiento del tejido óseo apoyándose en los principios de la regeneración ósea: osteogénesis, osteoconducción y osteoinducción.

\subsubsection{OSTEOGÉNESIS}

Es el proceso de formación del tejido óseo independientemente del origen de las células a partir de las cuales se va a formar, pudiendo ser las células responsables las que se encuentran en zonas periféricas (Gray y Elves, 1982), o las de la superficie del injerto (Eggers y Meeder, 1994), que mantienen su viabilidad gracias a su nutrición por mecanismos de difusión. El hueso esponjoso, dado que tiene una mayor superficie para 
albergar células, posee una mayor capacidad osteogénica que el hueso cortical (Drosse y cols, 2008; Kanczler y cols, 2008).

\subsubsection{OSTEOINDUCCIÓN}

Es el proceso por el cual se produce la proliferación y diferenciación de células mesenquimales hacia aquellas células formadoras de hueso (Urist y cols, 1965). La osteoinducción por parte de los injertos mineralizados parece ser muy limitada, pero la de los injertos de matriz ósea desmineralizada ha sido confirmada por muchos autores (Mulliken y cols, 1981; Bolander y cols, 1986; Lewandrowski y cols, 1997). Estudios realizados en hueso desmineralizado con el fin de analizar su capacidad osteoinductora condujeron al descubrimiento de la proteínas morfogénicas óseas (BMP: bone morphogenic protein). Las $B M P$ son miembros de la superfamilia $T G F-\beta$ (factor transformador del crecimiento beta). Estas proteínas participan en diversos procesos biológicos celulares como reguladores multifuncionales del crecimiento celular, diferenciación y apoptosis y juegan un papel relevante durante el desarrollo. De todas ellas, las más importantes son la BMP 2, BMP 4 y BMP 7 (Groeneveld y cols, 2000; Reddi y cols, 1997). La matriz ósea contiene además de las $B M P, T G F-\beta$, factor de crecimiento tipo insulina I y II $(I G F)$, factor de crecimiento de fibroblastos $(F G F)$, factor de crecimiento de plaquetas $(P D G F)$, interleuquinas, factor estimulador de colonias de granulocitos ( $G C S F)$ y granulocitos-monocitos (GM-CSF) (Mohan y cols, 1991; Dale y cols, 1995). Todas estas sustancias son capaces de inducir o influir en la diferenciación de las células mesenquimales hacia células formadoras de hueso.

\subsubsection{OSTEOCONDUCCIÓN}

Es el proceso por el que el injerto genera unas condiciones que le permiten soportar en su estructura el tejido vascular y perivascular, así como las células osteoprogenitoras, 
permitiendo de esta manera, la sustitución gradual del injerto por la formación de hueso nuevo. Este proceso sigue unas pautas predecibles a partir de un patrón espacial ordenado, determinado por la estructura del injerto, aporte sanguíneo, las propiedades a las que es sometido y la presencia de otros biomateriales que le puedan afectar (Abukawa y cols, 2006).

\subsection{INJERTOS ÓSEOS}

Las técnicas utilizadas para la reparación de defectos óseos producidos por malformaciones, traumatismos, infecciones o resecciones oncológicas tienen como finalidad la restitución y regeneración de dichos defectos respetando la morfología original e intentando devolver la máxima funcionalidad. Estas técnicas abarcan el uso de injertos de origen animal o humano, materiales sintéticos así como la aplicación de estructuras tridimensionales para la ingeniería de tejidos.

\subsubsection{AUTOINJERTOS}

Trasplante de tejido de una localización a otra del mismo individuo. Representa la mayor tasa de éxitos dentro de los injertos óseos, ya que son básicamente tejidos vivos con sus células intactas y no hay reacción inmunológica ni de rechazo. La mayor desventaja es que la extracción del tejido requiere intervenciones quirúrgicas complejas y costosas, necesitando un periodo de recuperación y existiendo riesgo por exposición e infecciones en la zona donante (Damien y Parson, 1991). Se considera el gold standard en la reparación y regeneración ósea (Stevenson y cols, 1999; Whang y cols, 2003), ya

que el propio injerto reúne propiedades osteoconductivas al ser en sí misma matriz donde las células óseas pueden proliferar (Dimitriou y cols, 2011); osteoinductivas, ya que posee factores de crecimiento que estimulan la proliferación y diferenciación hacia 
osteoblastos (Estrada y cols, 2006); osteogénicas ya que contiene las propias células que formarán el nuevo tejido (Logeart-Avramoglou y cols, 2005).

\subsubsection{ALOINJERTOS}

Trasplante de tejidos entre individuos de la misma especie. En el caso de los injertos óseos se usan tejidos de donantes que hayan fallecido recientemente. Antes de ser implantados estos tejidos se someten a una serie de tratamientos (como irradiación; freeze-drying, que son tratamientos térmicos con ciclos de ultracongelación; lavado ácido y otros tratamientos de tipo químico) con el fin de evitar reacciones inmunológicas o la contaminación cruzada (Khan y cols, 2005). Este tratamiento del injerto previo a la implantación va a generar unas peores condiciones en cuanto a su calidad: bajo grado de celularidad y menor revascularización, por lo que sus propiedades osteogénicas y osteoinductivas son más limitadas que con el injerto autólogo (Habibovid y cols, 2007). La mayor desventaja de esta técnica sigue siendo la disponibilidad del donante y la alta tasa de reabsorción de este tipo de injertos (Fodor y cols, 2003; Laurencini y cols, 1996).

\subsubsection{XENOINJERTOS}

Trasplante de tejidos entre dos especies distintas. Un ejemplo es el uso de hueso de origen bovino (Maiorana y cols, 2011) o porcino (Barone y cols, 2008) tratados mediante procesos de deshidratación y liofilización. Tiene la gran ventaja de que esta técnica nos permite obtener mayores cantidades de hueso, aunque presenta limitaciones, debidas al riesgo de transmisión de enfermedades infecciosas. 


\subsubsection{CLASIFICACIÓN DE LOS INJETOS ÓSEOS}

Los injertos óseos se clasifican según su estructura y su procedencia en los siguientes tipos (Ortiz Cruz y cols, 2000; Bauer y Muschler, 1999; Stevenson y cols, 1999):

- Autoinjerto óseo esponjoso. Su capacidad de soporte estructural es muy baja, pero la rapidez con la que estimula la formación ósea (rápida revascularización) facilita la estabilidad progresiva del lecho. Se obtiene generalmente de cresta iliaca (Stevenson y cols, 1999; Yonger y cols. 1989).

- Autoinjerto cortical no vascularizado. Aporta un gran soporte estructural al lecho donde se implanta, pero tiene una menor capacidad osteogénica (su revascularización es lenta debido a que su estructura cortical no permite la penetración vascular hasta que la actividad osteoclástica periférica la facilita) (Burwell y cols, 1969).

- Autoinjerto cortical vascularizado. Cuando su soporte estructural es estable, permite una rápida consolidación y su función es bastante independiente del lecho receptor (Hornicek y cols, 1999; Goldberg y cols. 1990). Se calcula que debido al aporte vascular, aproximadamente el $90 \%$ de los osteocitos pueden sobrevivir a la isquemia (Canosa y cols, 1997; Stevenson y cols, 1999).

- Matriz ósea alogénica desmineralizada. Requiere la colonización celular y vascular, para luego ser reabsorbida y sustituida por nuevo hueso favoreciendo la reparación ósea por osteoconducción (Boyce y cols, 1999). Su capacidad de inducir la nueva formación de hueso ha sido descrita en distintos trabajos basados en la teoría de la osteoinducción de Urist (1965), al demostrar en un modelo animal que fragmentos de hueso cortical de fémur de rata, implantados subcutáneamente, generaban hueso. La 
importancia biológica para la evaluación científica de los mecanismos de regeneración ósea, así como para la ciencia aplicada fue extraordinaria. Este nuevo biomaterial aportaba propiedades oesteoconductoras y oestoinductoras, es decir, que la matriz de hueso desvitalizada y desmineralizada provocaba la inducción sobre las células mesenquimales extraesqueléticas hacia la diferenciación a condroblastos y consecuentemente a la formación de hueso. La purificación de sus componentes activos dio lugar a un grupo de moléculas pertenecientes al grupo de las proteínas morfogenéticas.

- Aloinjerto triturado. Su gran estructura porosa confiere muy poca estabilidad, pero favorece una importante vascularización desde el lecho receptor. En este caso puede derivar tanto de hueso cortical como esponjoso.

- Aloinjerto corticoesponjoso y cortical. Buen soporte estructural, pero baja capacidad osteoinductiva (Stevenson, 1999). Se extrae frecuentemente de la cresta iliaca, fémur distal o tibia proximal. Tras su extracción se conserva a $-70^{\circ} \mathrm{C}$, manteniendo este proceso de congelación sus propiedades mecánicas, permitiendo su inmediata implantación tras su descongelación (Burchardt y col, 1983). Como la liofilización altera las condiciones del hueso cortical, hay que rehidratarlo, con lo cual perderá su resistencia ante la flexión y torsión.

- Aloinjerto masivo osteocondral. Se usan en las reconstrucciones articulares tras la cirugía tumoral. Estos injertos incluyen hueso cortical, hueso esponjoso metafisario y cartílago articular (Stevenson, 1999). 
Los injertos también se clasifican según el proceso al que son sometidos desde su extracción hasta su implantación en la zona receptora: fresco (vascularizado o no vascularizado), congelado, liofilizado, deshidratado, irradiado y desmineralizado.

\subsection{MATERIALES SINTÉTICOS PARA LA REGENERACIÓN ÓSEA}

Atendiendo a su composición, podemos hablar de :

- Metálicos. Uno de los requisitos fundamentales para lograr la regeneración ósea es la estabilidad mecánica del foco o defecto óseo. Estos materiales son los que mayor estabilidad ofrecen al defecto en forma de osteosíntesis y fijación de los injertos y distintos biomateriales. Para este fin se usan placas, mallas, tornillos... generalmente de titanio, vitalio y en menor grado acero.

- Polímeros. Se han usado más como reparadores y no como verdaderos regeneradores de hueso. Se han utilizado resinas acrílicas: polimetilmetacrilato o polietilmetacrilato y 2-polihidroxietilmetacrilato. También se han usado polietilenos: polipropileno o polietileno; siliconas: dimetilsiloxano; polímeros fluorados: politetrafluoretileno (PTFE). También pertenecen a este grupo los polímeros reabsorbibles del ácido poliláctico (PLA), copolímeros de ácido poliláctico/poliglicólico (PLA/PGA), los cuales se han estudiado ampliamente como materiales transportadores de $B M P s$, y polímeros no reabsorbibles de PTFE (muy usados en la fabricación de membranas osteorregenerativas) (ilustración 4). 


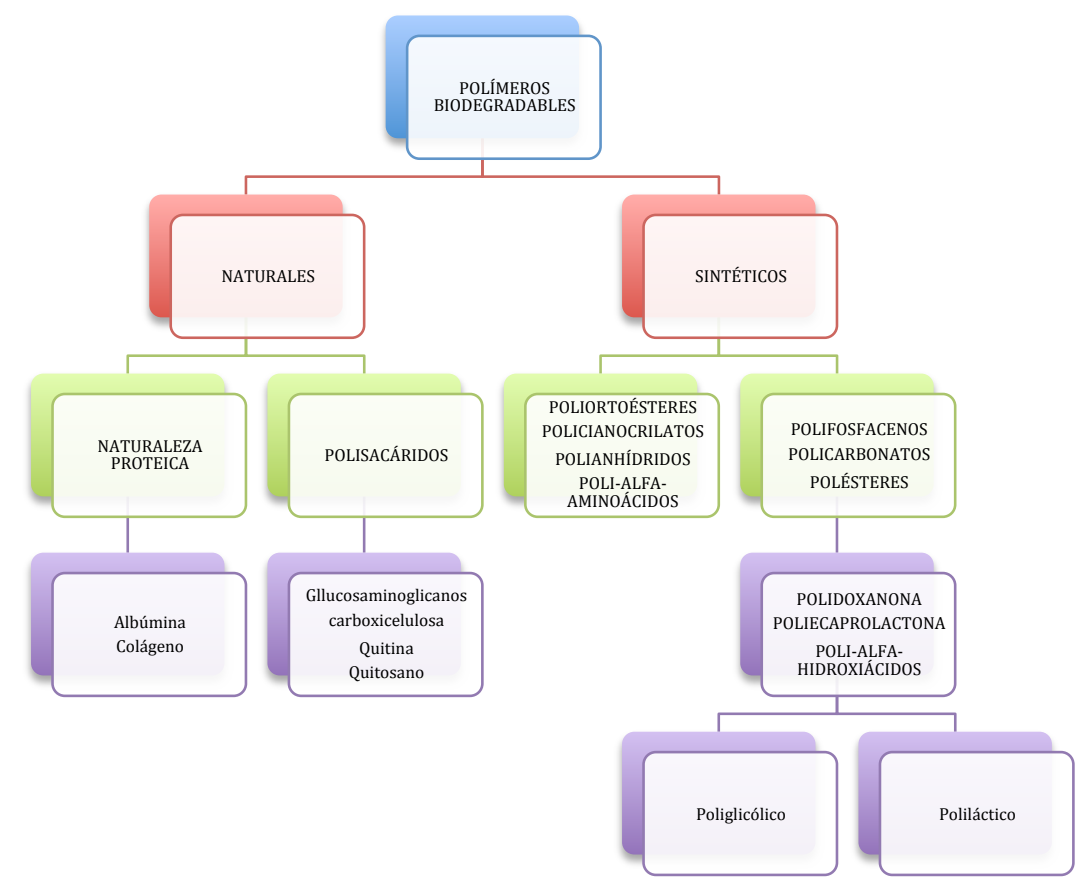

Ilustración 4. Esquema resumen de los distintos tipos de polímeros con aplicación biomédica (Kulkarni y cols, 1966).

- Cerámicos. Son todos los cuerpos sólidos fabricados a partir de materiales inorgánicos (no metales) sometidos a un tratamiento térmico de $800^{\circ} \mathrm{C}$. Según su comportamiento se dividen en: cerámicas bioinactivas, son aquellas que no generan ningún cambio iónico con el medio, pero al ser colocada sobre tejido vivo genera proceso de osteogénesis al producirse un íntimo contacto entre la superficie del hueso laminar y la superficie de la cerámica: cerámicas de óxido de Aluminio. Las cerámicas bioactivas son aquellas que interaccionan con el medio, produciéndose una unión físico-química, produciéndose osteogénesis por la liberación de iones al medio y la inclusión de estos al metabolismo óseo (Gross y Strunz 1985): cerámicas de fosfato cálcico en sus distintas formas de hidroxiapatita; fosfato tricálcico; sulfato de calcio. También pertenecen a este grupo los vidrios activos, cristales bioactivos o vitrocerámicas. 


\section{MATERIALES}

\section{POLÍMEROS}

CERAMICOS
APLICACIONES

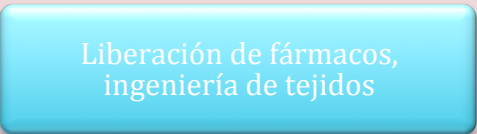

Placas de osteosíntesis, clavos, tornillos, implantes dentales

Relleno de cavidades y defectos óseos. Prórtesis de cadera

Ilustración 5. Resumen de los materiales más frecuentemente utilizados y sus aplicaciones,

En resumen, los criterios ideales de los injertos óseos según Block y Kent son:

- Capacidad de producir hueso por proliferación celular de osteoblastos o por conducción celular a lo largo de la superficie del injerto.

- Capacidad de producir hueso por inducción de las células mesenquimales incluidas en el injerto.

- Remodelado del hueso inicialmente formado en hueso laminar duro.

- Mantenimiento del hueso maduro a través del tiempo sin que la función cause pérdida del mismo.

- Bajo riesgo de infección.

- Baja antigenicidad. De todos los factores que pueden influir en el proceso de incorporación ósea el papel de la respuesta inmunitaria está siendo cada vez más reconocido en el éxito o fracaso del aloinjerto (Garbuz y cols, 1998).

- Fácil manipulación. 


\section{INGENIERÍA DE TEJIDOS}

Skalak y Fox definieron a finales de la década de los ochenta la ingeniería tisular como aquella materia que se vale de los distintos principios y métodos de la ingeniería, biología y bioquímica, aplicándolo al conocimiento de la estructura y función de los tejidos normales y patológicos, y el consecuente estudio del desarrollo de sustitutos biológicos con el fin de mantener, recuperar o mejorar su función.

La ingeniería tisular es una disciplina que se está desarrollando a gran velocidad y tiene como finalidad reparar y reemplazar tejidos específicos y órganos, apoyada en el conocimiento de la medicina, física, química y la biología, a través de la convergencia de tres elementos como son las distintos tipos de células, las matrices que soportarán dichas células y las distintas moléculas específicas de señalización. Todo ello en un microambiente idóneo facilitará la formación de un nuevo tejido (Estrada y cols. 2006) (ilustración 6).

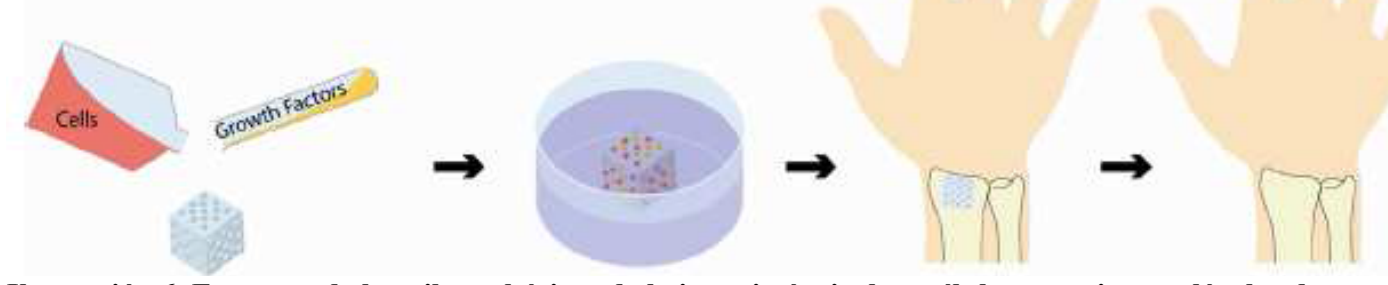

Ilustración 6. Esquema de los pilares básicos de la ingeniería tisular: células, matriz y moléculas de señalización (Drosse y cols. 2008).

La confluencia de todos estos elementos nos permitirá desarrollar distintas estrategias de ingeniería tisular, las cuales se pueden dividir en cuatro grandes grupos (Muschler y cols, 2004), que desarrollaremos más adelante:

1. Evolución natural del tejido conectivo donde el nuevo tejido es requerido. 
2. Trasplante de tejido conectivo autólogo.

3. Trasplante de celulas expandidas o modificadas procedentes de tejido conectivo.

4. Trasplante de tejido totalmente formado in vivo o in vitro.

Dichas estrategias de ingeniería tisular buscan optimizar la formación de un nuevo tejido mediante una serie de condiciones, que modulen la activación de un tejido conectivo en el lugar del injerto para producir el tejido deseado. Este avance combina estrategias celulares, matrices, estrategias de estimulación inductiva y técnicas que aumentan la supervivencia y activación del tejido conectivo trasplantado o local.

La ingeniería tisular incluye el trasplante de clelulas y tejidos con el uso de distintas técnicas de cirugía microvascular como son el uso de colgajos pediculados, trasplante de mínimas secciones de tejido, trasplante de suspensiones celulares y el recambio endoprotésico de tejidos.

En los últimos años se ha producido un aumento en las distintas opciones para la ingeniería de tejidos en los diferentes áreas, especialmente en el campo aplicado a la ortopedia. Entre estas opciones nos podemos encontrar diversos métodos para el cultivo y el trasplante de tejidos formados a partir de células, el uso de un gran número de materiales bioactivos como andamiajes tisulares, la liberación local o sistémica de hormonas y factores de crecimiento, y otros métodos para controlar química y biofísicamente el entorno.

Estas nuevas alternativas nos muestran una transición desde los clásicos tejidos basados en diferentes materiales, siempre dando prioridad a los mecánicamente más duraderos, bioinertes y biocompatibles, hasta las distintas terapias celulares y materiales bioestimulantes y bioactivos. Este desarrollo nos acerca de forma muy significativa a la 
función celular y al papel primordial que juegan los materiales implantados gracias a la estimulación biofísica modulando la función celular.

Todo esto, llevado al campo de la ingeniería tisular ósea, se basa en la confluencia de factores osteogénicos entendidos como todas aquellas células que participan en la formación ósea, factores osteoinductivos, es decir, aquellas moléculas que intervienen directamente en la diferenciación y proliferación de las células progenitoras, y un factor osteoconductivo, que permitirá el soporte y adhesión celular (Bancroft y Mikos, 2001). La ingeniería tisular basada en el concepto celular está generando nuevas oportunidades que pueden ser muy útiles para diferentes aplicaciones clínicas. Estos avances generan una importante necesidad que obliga a que la cirugía ortopédica participe activamente en el diseño, desarrollo, evaluación crítica e información sobre el uso de estos métodos.

\subsection{CÉLULAS MADRE}

Las células madre es la denominación más extendida cuando nos referimos a stem cells o células troncales. Es una célula inmadura, es decir que se encuentra en un estadio temprano de desarrollo y tiene la capacidad de dividirse indefinidamente (autorrenovación), además las células que se generan al dividirse son réplicas idénticas (clonogenicidad) y son viables a lo largo de extensos periodos de tiempo. Son células con una capacidad de diferenciarse hacia distintos tejidos del organismo generando una descendencia celular muy especializada (multipotencialidad) (Hall y Watt, 1989; Cancedda y cols, 2003; Zuck y cols, 2002).

Las células madre se pueden clasificar de diferentes maneras:

\section{Según su potencial de diferenciación:}

- Totipotenciales, con capacidad para crecer y formar un organismo completo. 
- Pluripotentes. Pueden dar origen a progenitores que forman cualquiera de las tres capas germinales embrionarias: mesodermo, endodermo y ectodermo. Además tienen que demostrar la funcionalidad in-vitro e in-vivo de las células en las que se han diferenciado y tienen que producir un asentamiento claro y persistente en el tejido diana, ya sea en presencia como en ausencia de lesión (Orlic y cols, 2001).

- Multipotenciales. Son aquellas que pueden dar origen a precursores relacionados solamente con una de las tres capas embrionarias, como por ejemplo células madre que dan origen a tejidos derivados exclusivamente del endodermo como tejido pancreático o pulmonar, o mesodermo como tejido musculoesqulético (Beceerra y cols, 2001)

- Unipotenciales. Son células que sólo pueden generar células hijas que se diferencian a lo largo de una sola línea celular. Hasta hace algunos años, se consideraba a las células madre hematopoyéticas de médula ósea en esta categoría, ya que se relacionaban solamente con la generación de células sanguíneas. La mayor parte de las células de un tejido específico que no han sufrido ningún tipo de agresión o daño son del tipo unipotencial y son las responsables de la fase fisiológica de autorrenovación tisular, donde la cantidad de células perdidas es igual al número de nuevas células. Sin embargo, si el tejido es alterado en su estructura básica a partir de algún tipo de lesión, y se requiere de diferentes tipos celulares para su reparación y recuperación, se pueden activar células del tipo pluripotencial para reparar de esta manera el daño originado (Weissman y cols, 2000).

\section{Según el tejido de origen :}

- Células madre embrionarias.

- Células madre adultas. 
Además de las citadas clasificaciones también genera un gran interés los diferentes mecanismos de diferenciación celular a los que pueden ser conducidas, desde el modelo convencional célula madre-célula hija hasta procesos de de-diferenciación y transdiferenciación celular; es así como estos modelos son aplicados en la actualidad para entender el fenómeno de la plasticidad, reconocido en este tipo de células, que es la capacidad que tienen estas células para generar grupos celulares diferentes a los de su tejido origen.

\subsubsection{CÉLULAS MADRE EMBRIONARIAS}

Conocidas por su nomenclatura en inglés como Embryonic stem cells (ESC). Pueden ser obtenidas a partir del día catorce cuando el óvulo fecundado se encuentra en fase de blastocisto (Verfaillie y cols, 2002). Pueden diferenciarse hacia todos los tipos de célula somática, así como hacia células de la línea germinal (Evans y Kaufman, 1981; Martin 1981; Pedersen, 1994). Las células madre embrionarias (derivadas del blastocito) y las células embrionarias germinales (derivadas de la postimplantación del blastocito), son similares en muchos aspectos; ambos tipos de células pueden replicarse y dividirse en cultivos por largos periodos de tiempo, sin mostrar alteraciones cromosómicas. Además expresan una serie de marcadores característicos de progenitores pluripotenciales que facilitan su identificación; sin embargo, las células madre embrionarias derivadas del blastocito y las células germinales difieren del tejido de donde provienen y de su comportamiento in vivo ya que las células madre embrionarias son capaces de generar teratomas mientras que las células germinales humanas no (Odorico y cols, 2001; Shamblott y cols, 1998). Una de las mayores ventajas del uso de células madre embrionarias es su habilidad de proliferar indefinidamente, ya que son capaces de generar una gran variedad de grupos celulares, lo que permite, que bajo ciertas 
condiciones, puedan ser manipuladas in vitro con el fin de producir precursores de un linaje específico y contribuir así a la investigación y el estudio del tratamiento de ciertas enfermedades como diabetes y Parkison, en las que existen tejidos claramente comprometidos. Además, pueden ser utilizadas para estudios sobre enfermedades durante el desarrollo embrionario y contribuir a identificar sus bases genéticas (Weissman y cols, 2000). Sin embargo, presentan una serie de inconvenientes al tratarse de células muy indiferenciadas: éstas pueden inducir la formación de ciertas neoplasias como teratomas. En un estudio de implantación de células embrionarias humanas en ratones inmunodeficientes, éstos desarrollaban teratocarcinomas que contenían células y tejidos de las tres capas germinales (Kehat y cols, 2004). Además no hay que olvidar las importantes implicaciones éticas que el uso de estas células conlleva (Pera y cols, 2000; Zuck y cols, 2002). Para solucionar este punto de conflicto ético, Yamanaka en el año 2006 desarrollaron lo que se conoce como células pluripotentes inducidas (iPS) a partir de la manipulación de células adultas por medio de la transferencia de genes capaces de reprogramar la pluripotencialidad de la célula diana (Takahashi y cols, 2007; Barret y cols, 2014). Hay autores que muestran, en sus diversos trabajos, un carácter más tumorogénico en este tipo de células que en las células madre embrionarias (Gutiérrez-Aranda y cols, 2010).

\subsubsection{CÉLULAS MADRE ADULTAS}

Se pueden encontrar en la mayoría de los tejidos de un individuo totalmente desarrollado, como la médula ósea, el sistema neuronal, el sistema gastrointestinal, el músculo esquelético, el músculo cardíaco, el hígado, el páncreas y el pulmón. Éstas se encuentran rodeadas de un microambiente específico y, ante determinadas condiciones físico-químicas, comienzan a dividirse y se diferencian hacia células especializadas de la misma capa germinal (Fuchs y cols, 2004). En un principio, se pensó que las células 
madre adultas estaban predeterminadas para diferenciarse a un tipo celular procedente de su mismo tejido de origen o al menos de su misma capa embrionaria, de este modo las células madre hematopoyéticas residentes en la médula ósea darían lugar solamente a elementos celulares hemáticos (Morrison y cols, 1995). Sin embargo, esta idea ha sido reevaluada posteriormente por varios grupos de investigadores, cuyos estudios indican que las células madre adultas son células con propiedades de multipotencialidad, capaces de diferenciarse funcionalmente a células especializadas procedentes de capas embrionarias distintas de las de su origen (Sánchez y cols, 2006). Las células madre adultas más estudiadas hasta ahora, son las que derivan de la médula ósea (del inglés Bone Marrow Stem Cells: BMSC). La médula ósea humana deriva del mesodermo embrionario y se compone de una población celular muy heterogénea: células madre mesenquimales, células progenitoras hematopoyéticas, células progenitoras endoteliales y líneas celulares más diferenciadas (monocitos, granulocitos, linfocitos T y B, NK...) (Friedstein y cols, 1968; Tomita y cols, 1999; Jackson y cols, 2001; Orlic y cols, 2001).

Las células madre hematopoyéticas son las responsables de la renovación constante de las células sanguíneas (Weissman cols, 2000). Aparecen en el embrión entre la tercera y cuarta semana de gestación, migran desde el saco vitelino hasta el hígado y el bazo, y por último, llegan a la médula ósea a través de la circulación fetal durante el segundo y tercer trimestre de gestación. Tienen la capacidad de autorrenovarse y diferenciarse en dos grupos de progenitores hematopoyéticos: progenitor mieloide y progenitor linfoide, los cuales a su vez se diferencian a células sanguíneas especializadas (Gasparoni y cols, 2000; Fliedner y cols, 1998). El aislamiento de subpoblaciones de células madre hematopoyéticas ha sido posible mediante la identificación de sus marcadores de superficie. En el caso del ratón estamos hablando del receptor del factor de célula madre (c-kit), el Sca-1 (antígeno 1 de célula madre), el Thyl y los marcadores de línea 
hematopoyética, que son los más utilizados para identificar células progenitoras hematopoyéticas en la médula ósea (Orlic y cols, 2001). En humanos los antígenos que se emplean son CD117, CD34 y CD133 (progenitor de estirpe endotelial) para aislar progenitores hematopoyéticos purificados. Así se pueden aislar subpoblaciones más específicas, cada una con sus propiedades (Bhatia y cols, 2001). Sin embrago, hasta ahora no se ha encontrado un antígeno específico para identificar a las células madre hematopoyéticas que se encuentran en un estadio temprano de diferenciación. Estas células se integran en localizaciones donde se producen fenómenos de neovascularización y en ellas se diferencian hacia células endoteliales adultas, segregando factores proangiogénicos. El aislamiento de este tipo de células a partir de sangre periférica, generalmente requiere una fase de tratamiento previo con un factor estimulante de colonias de granulocitos $(G-C S F)$, y posteriormente se procede al uso de técnicas de citoaféresis. (Blocklet y cols, 2005). Sin embargo, en estudios clínicos con humanos se ha concluido que el pretratamiento con $G$-CSF puede estar asociado a una mayor incidencia de complicaciones (Kang y cols, 2004; Maekawa y cols, 2004).

Las células madre hematopoyéticas son la base biológica de los trasplantes de médula ósea para pacientes que padecen patologías como leucemias y aplasias medulares; sin embargo, la obtención de donantes compatibles con el receptor y los costes que implican estos procedimientos han creado la necesidad de buscar fuentes alternativas para la obtención de este tipo de células. Una alternativa interesante para la obtención de este tipo de células constituye la sangre del cordón umbilical.

En las últimas décadas se ha estudiado el uso de estas células en terapia regenerativa, investigando el uso de la implantación de estas células autólogas en el miocardio para prevenir el proceso de remodelación responsable de la insuficiencia cardiaca postinfarto ya que las $C D 34$ liberan factores de crecimiento que activan a las células madre residentes en el miocardio, las cuales pueden diferenciarse hacia células endoteliales y 
favorecer así la neoangiogénesis (Assmus B y cols, 2002; Stamm C y cols, 2003, San Román y cols, 2015).

Las células madre endoteliales tras su salida a sangre periférica, expresan $C D 133$, $C D 34$ y el receptor 2 del factor de crecimiento vascular endotelial $(K D R)$, y cuando se integran en localizaciones donde está teniendo lugar fenómenos de neovascularización se transforman en células maduras (Asahara y Kawomonto, 2004).

Células madre mesenquimales: MSC (Mesenchymal Stem Cells). Constituyen un grupo muy homogéneo de células de apariencia fibroblastoide (Gerson, 1999), y distintas características inmunofenotípicas. En la médula ósea se encuentran en proporciones muy bajas (una de cada 3 millones de células mononucleares) (Chen y cols, 2004). También se pueden encontrar en el tejido adiposo (Wagner y cols, 2005), en ligamento periodontal, pulpa o folículo dental (Huang y cols. 2009; Alkhalil y cols. 2015), en el cerebro, corazón, pulmón y riñón (Salem y cols. 2010). También se pueden obtener a partir de la sangre menstrual y del endometrio residual, lo que evitaría la morbilidad asociada a la obtención de MSC directamente de distintos órganos (Rossignoli y cols, 2013). A lo largo del tiempo han tenido distintas denominaciones: unidades formadoras de colonias de fibroblastos (CFU-F), células madre estromales o células del estroma medular. Actualmente se denominan MSC porque los tejidos hacia los que puede diferenciarse son de origen mesenquimal.

La Sociedad Internacional de terapia Celular resume las características que deben cumplir estas células para ser consideradas como tal (Dominici y cols. 2006):

- Mostrar adherencia al plástico en condiciones estándar de cultivo (Wakitani y cols, 1995; Blau y cols, 2001)

- Capacidad de diferenciación hacia distintas líneas tisulares mesenquimales (capacidad osteogénica, adipogénica y condrogénica) (Firedstein y cols, 1976; Caplan y cols, 1991). 
- Potencial de autorrenovación y alta capacidad de proliferación.

- Deben ser positivas para la expresión de CD 29, CD44, CD49a-f, CD51 CD73, CD90, CD105, CD106, CD166 Y Strom-1 y negativos para expresar marcadores hematopoyéticos c-kit, CD11b, CD14, CD19, CD34, CD45, CD79 $\alpha$, antígeno leucocitario humano HLA-DR.

Aunque el papel que se atribuyó a las MSC originariamente fue el ser fuente de células osteoprogenitoras, Friedstein y cols. en 1966 fueron los primeros en publicar que dichas células eran capaces de diferenciarse a distintas líneas mesenquimales, hecho que ha sido confirmado en sucesivos estudios (Friedstein y cols, 1976; Asthon y cols, 1980; Pittenger y cols, 1999; Dennis JE, 1999). Por tanto, en un entorno adecuado, las MSC pueden diferenciarse a osteoblastos, condroblastos, adipocitos, tenocitos y mioblastos. Esta última línea miogénica, tiene gran interés por la diferenciación hacia cardiomiocitos (Wakitani y cols, 1995). En los últimos años se ha demostrado que estas células tienen la capacidad de diferenciación hacia tipos celulares derivados de otras capas germinales (tejidos de origen embriológico ectodérmico y endodérmico) (Sánchez-Ramos y cols, 2000), pudiendo por tanto dar lugar a una línea neurogénica: astrocitos, oligodendrocitos y neuronas (Azizi y cols, 2013), y una línea endotelial (Reyes y cols, 2002). A este potencial de generar distintas células de las tres capas germinales se le conoce como plasticidad (Wagers y Weissman, 2004; Rutenberg y cols, 2004; Sánchez y cols, 2006). Esta característica fue reconocida por primera vez en estudios realizados en MSC derivados de la médula ósea, donde se observaron cambios en el fenotipo en células inmaduras bajo condiciones controladas que simulaban microambientes diferentes al medular (Robey, 2000). Los mecanismos moleculares que llevan a los cambios de linaje celular dentro del sistema hematopoyético están siendo estudiados descartando definitivamente el dogma, que hace años existía, sobre la 
diferenciación de las células madre, restringida a su tejido de origen. Evidencias obtenidas tanto in vivo como in vitro, muestran que las células madre adultas, originadas en un tejido determinado tienen la capacidad de producir células con una expresión fenotípica característica de otros tejidos cuando se transfieren a una microambiente distinto del original. De una forma muy particular se ha prestado atención a la capacidad de las células madre adultas de la médula ósea de producir células con propiedades similares a hepatocitos, neuronas y cardiomiocitos (Körbling y Estrov, 2003; Lagasse y cols, 2000; Ogawa y cols, 2002; Tsai y cols, 2002). Existen distintas teorías que explican los posibles mecanismos que llevan a las células madre adultas a diferenciarse hacia un tejido distinto al original (ilustración 7):

- Heterogenicidad de las células madre presentes en una población celular. En determinados tejidos, especialmente la médula ósea, coexisten diferentes tipos de células madre con distintas características. Esto ha planteado que la regeneración de tejidos no hematopoyéticos que se ha observado después de la infusión de células procedentes de la médula ósea, podría deberse a la acción específica de alguno de los tipos de células madre que actualmente se han identificado en ella y no a la transdiferenciación de la célula madre hematopoyética (Verfaillie CM, 2002; Jiang y Vaeesen B, 2002; Jiang y Jahagirdar BN, 2002).

- Fusión de las células madre trasplantadas con las células específicas residentes en un tejido. La fusión de mioblastos con fibroblastos induce en estos últimos la expresión de proteínas propias del músculo, lo que ha sugerido la existencia en los mioblastos de algunos factores que pueden inducir la diferenciación muscular de otros tipos de células (Verfaillie CM, 2002). Por otro lado, se ha señalado que el contacto intercelular podría tener una acción importante en la fusión de una célula incorporada a un nuevo microambiente. Este mecanismo daría lugar a células híbridas con características de ambas células fusionadas, pero con la desventaja de poseer una menor 
capacidad proliferativa, ya que generalmente debido a la fusión adquieren doble dotación cromosómica (Prosper y cols, 2003). El mecanismo de fusión celular se ha comprobado en diferentes estudios experimentales con ratones en que la mayor parte de las células híbridas eran tetraploides o hexaploides (Körbling y Estrov, 2003; Wang X y cols. 2003). Sin embargo, muchas de las células específicas de tejidos y con marcadores propios del donante que se han identificado en pacientes que han recibido trasplantes alogénicos de células madre hematopoyéticas, han mostrado una dotación cromosómica normal. Para compatibilizar esta situación, se sugirió que tal vez la célula fusionada hiperdiploide podía evolutivamente llevar su dotación cromosómica a un estado diploide, aunque estudios posteriores no han favorecido esta hipótesis (Körbling y Estrov, 2003). No existe ningún estudio que permita eliminar la posibilidad de la fusión celular como uno de los mecanismos de plasticidad aunque es muy poco probable. Quizás la fusión pudiera explicar la transformación celular en determinados tejidos donde la frecuencia de los otros mecanismos sea extremadamente baja (Verfaillie CM, 2002).

- Procesos de desdiferenciación y rediferenciación o transdiferenciación celular. Es un proceso de metaplasia que se produce en una célula ya diferenciada en determinadas situaciones ambientales. Tal como sucede durante el proceso de la clonación celular, en que el núcleo de una célula somática es sometido a un proceso de reprogramación genética. Se ha planteado la posibilidad de que las células madre adultas pudiesen ser reprogramadas cuando se extraen de su microambiente natural y se sitúan en otros diferentes en los cuales reciben estímulos y señales que las inducen a la activación de un nuevo programa genético que las llevan a diferenciarse en células del nuevo tejido en que se ha implantado. De esta forma, una célula genéticamente comprometida puede sufrir un proceso de desdiferenciación mediante un salto atrás en su etapa de maduración y adquirir por esta razón una nueva capacidad regenerativa, que 
le permite después rediferenciarse en células madre especializadas de estirpes diferentes (Verfaillie CM, 2002; Körbling y Estrov, 2003; Prosper F y cols., 2003).

- Persistencia de células madre adultas con capacidad multi o pluripotencial.

Tras el periodo embrionario pueden persistir células madre con capacidad multi o pluripotencial, que en dependencia del medio en que se sitúen pueden diferenciarse hacia células de diferente linajes (Verfaillie CM, 2002; Körbling y Estrov, 2003; Prosper F y cols, 2003).

A

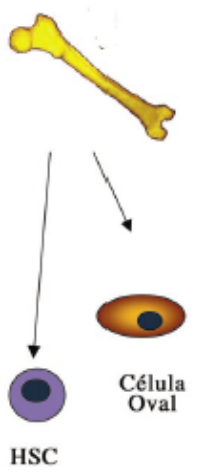

$\mathrm{B}$

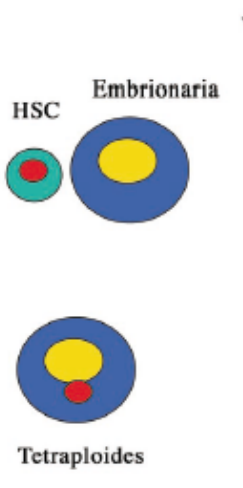

$\mathrm{C}$

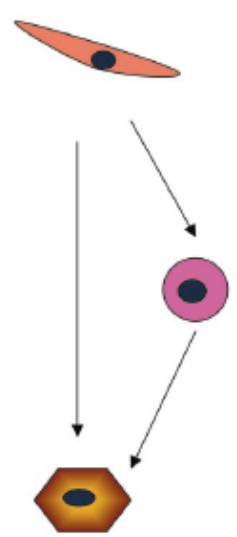

$\mathrm{D}$

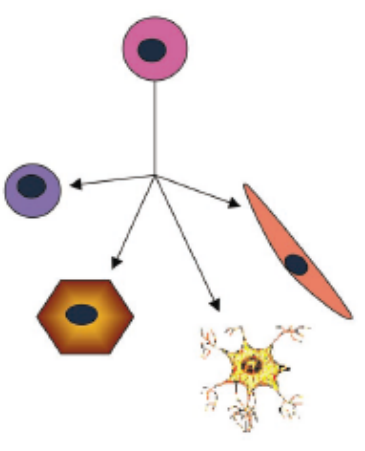

lustración 7. Esquema de los distintos mecanismos por los que las MSC puede convertirse en una célula de distinto linaje A: heterogenidad de la población celular. B: fusión celular. C: trans-/de-diferenciación. D: pluripotencionalidad. (F. Prósper y CM. Verfaillie, 2003).

Existen distintos mecanismos capaces de inducir los procesos de plasticidad como la isquemia tanto aguda, como la pérdida en el número de células tras un infarto de miocardio (Leri y cols, 2005) como isquemia crónica (Silva y cols, 2005), el daño químico a un tejido (Collas y cols, 1999; Boquest y cols, 1999), el microambiente tisular (Wang y cols, 2000); las MSC pueden modificar in vitro su fenotipo bajo condiciones de cultivo específicas, por ejemplo se pueden diferenciar hacia cardiomiocitos, mediante inducción en cultivo con 5-azacitidina (agente demetilador del DNA) (Makino y cols, 1999). 
Las células madre y las células progenitoras están presentes en todos los tejidos adultos y son críticas para la salud del tejido y su mantenimiento respondiendo a la enfermedad y a la lesión a lo largo de la vida. Las células madre son la fuente de todos los nuevos tejidos y son moduladas a través de señales químicas y físicas que controlan su activación, proliferación, migración, diferenciación y supervivencia. Las células madre dan lugar a las células progenitoras, y se diferencian de éstas en su capacidad de renovación y regeneración propia por un proceso asimétrico de división celular. En contraposición, las células progenitoras, también llamadas células transicionales, proliferan y aumentan su número teniendo limitada su capacidad de renovación propia y se diferenciacian hacia la línea a la que están comprometidsa (Muschler y Midura, 2002; Muschler y cols, 2003).

Tanto las células madre, como las células progenitoras participan en un continuo sistema de recambio celular que implica a todas las células perdidas y la regeneración celular de prácticamente todos los tejidos, llevando a cabo la formación de nuevas células y la transición ordenada de un estado celular a otro. Este movimiento es mucho más evidente en el linaje de las células del tracto gastrointestinal (cada tres días), o la piel (cada catorce días). En el tejido musculoesquelético, este turnover es mucho más lento; en el hueso se produce una evolución celular donde las células que se forman y que soportan el tejido óseo progresan a través de una serie de estadios. Las células madre dan lugar a las células progenitoras, que se diferencian a pre-osteoblastos, y posteriormente llegan a osteoblastos. Estos últimos representan todavía una población transitoria con una vida que se extiende unos 40 días y que dan lugar a una matriz de tejido óseo y la cascada celular que forma dicho tejido. Cuando los osteoblastos alcanzan el final de su vida funcional, tienen tres posibilidades:

- Convertirse en osteocitos.

- Convertirse en revestimiento celular de la superficie del hueso maduro. 
- Morir por mecanismos de apoptosis.

Tanto osteocitos como las células de revestimiento pueden sobrevivir durante más de 20 años en el hueso cortical humano, hasta que la región de hueso en la se asientan es nuevamente remodelada por la progenie celular a partir de otras señales de células madre (Muschler y cols, 2003).

El hueso reparado, así como la regeneración ósea que sigue a una fractura o injerto óseo, continúa siguiendo los mismos pasos. Los mismos principios se pueden aplicar en músculo, tendón, ligamento y cartílago (Böstman y cols, 1990).

Podemos esperar un futuro prometedor para la regeneración de muchos tejidos, porque las células progenitoras son a menudo multipotenciales. Se ha observado la capacidad de diferenciación de las células madre mesenquimales provenientes de hueso, músculo, médula ósea y tejido graso a distintos fenotipos, incluido hueso cartílago, tendón, ligamento, grasa, músculo y nervio (Owen y cols, 1988; Gimble y cols, 1996). Esto tiene verdadera importancia respecto al diseño de las estrategias de ingeniería tisular: células derivadas de un tejido determinado pueden ser útiles en la formación de un tejido totalmente diferente.

Las fuentes de células madre y células progenitoras musculoesqueléticas incluyen médula ósea, tejido peritrabecular del hueso, periostio, cartílago, musculo, grasa y tejido vascular (Gimble y cols, 1996; O’Driscoll y cols, 1999; Garg y cols, 1995; Muschler y cols, 1997; Cannolly y cols, 1989; Brighton y cols, 1992). La aspiración de médula ósea está asociada a una menor morbilidad y nos facilita una suspensión celular que puede ser procesada de forma simple y rápida para su inmediata implantación intraoperatoria (Muschler y cols, 1997). El tejido adiposo se ha valorado mucho por su baja morbilidad en la fuente de origen del tejido, aunque requiere un procesado más complejo (Zuk y cols, 2001). 
Tanto las células madre como las células progenitoras de varios tejidos pueden ser aisladas in vitro, pudiendo producir un crecimiento en un cultivo bajo condiciones que promuevan la activación y proliferación de dichas células. Las células derivadas de un tejido conectivo pueden ser expandidas in vitro para su uso, ya sea en investigación o para su aplicación clínica. Bajo estas condiciones el cultivo empieza rápidamente a ser más uniforme; cuando las células crecen in vitro, los clones de células se dividen mucho más rápido y aquellas tienen una gran capacidad para continuar su proliferación. In vitro esta expansión produce, por tanto, una influencia selectiva que favorece estos rasgos. El cultivo expandido y la selección de poblaciones celulares han sido descritas con distintos nombres: células del estroma de la médula ósea (Owen y Friedstein, 1988), células madre mesenquimales (Caplan, 1991) o células adultas progenitoras multipotenciales (Jiang y cols, 2002; Reyes y cols, 2001). En todos los casos hablamos de células progenitoras que pueden aislarse y cultivarse bajo unas condiciones apropiadas y que pueden conservar la capacidad de diferenciación a variedad de fenotipos, entre ellos a células de estirpe musculoesquelética (Caplan y cols, 1991; Pittenger y cols, 1999).

La celuluaridad es distinta dependiendo del origen tisular de donde obtenemos las células. Todos los tejidos se diferencian unos de otros desde el punto de vista de la celularidad. La medula ósea es la mejor fuente que disponemos: por cada $1 \mathrm{ml}$ de médula obtenemos aproximadamente 40 millones de células nucleadas por lo que es muy importante que se realice una técnica de aspiración apropiada (Muschler y cols, 1998; Mushler y cols, 2001; Majors y cols, 1997). En contraposición observamos que el tejido graso y el músculo presentan mucha menor celularidad (6 millones por centímetro cúbico de tejido aspirado). El tejido conectivo derivado de médula ósea incluye células que tienen la capacidad de diferenciarse a distintos fenotipos: hueso, tejido fibroso, tejido adiposo, músculo, cartílago, y posiblemente a tejido nervioso, 
músculo cardíaco o hígado. Sin embargo el tejido conectivo del cartílago articular adulto sólo puede formar cartílago (Muschler y cols, 2003; Muschler y cols, 2002; Owen y Friedenstein, 1988; Caplan, 1991; Pittenger y cols, 2000; Aubin y cols, 1998; Bruder y cols, 1999). El conectivo derivado del tejido graso y músculo, parece que tiene también un gran repertorio de diferenciación (Gimble y cols, 1996; Huard y cols, 1998; Halvorsen y cols, 2000; Bosch y cols, 2000). Algunos autores sugieren que tejido graso y médula ósea son similares en cuanto a la capacidad de diferenciación (De Ugarte y cols, 2003). Otros estudios sin embargo, muestran mucha menor capacidad osteogénica en tejido graso (Winter y cols, 2003) y consideran la médula ósea la fuente más abundante de células madre mesenquimales (Haynesworth y cols 1992; Caplan, 1991).

Poco a poco se empieza a comprender mejor las diferencias que podemos encontrar en las distintas células cultivadas entre los distintos tipos de tejido: estas diferencias dependen de la salud y de las características histológicas a nivel local, así como de la cinética de las células madre en cada caso. Estas variables, además están influenciadas por la edad, sexo, y por las enfermedades tanto a nivel local como a nivel sistémico de cada paciente (Muschler y cols, 2001; D'Ippolito y cols, 1999). Por ejemplo, la celularidad de la médula ósea disminuye con la edad, de manera que a medida que el individuo envejece disponemos de menor celularidad (Muschler y cols, 2001), aunque generando un microambiente determinado, podemos obtener células osteogénicas mediante aspirado de médula ósea en pacientes de cualquier edad. Sin embargo el sexo parece no tener una influencia tan directa en la variación de la concentración y prevalencia de células entre los pacientes.

Las diferencias en el potencial biológico de las células derivados de los distintos tejidos pueden tener unas implicaciones prácticas muy importantes en relación a la selección de las diferentes fuentes celulares para la ingeniería tisular. 


\subsubsection{ESTRATEGIAS EN INGENIERÍA TISULAR}

Lo que resulta fundamental para cualquier estrategia de ingeniería tisular es que la célula utilizada alcance el tejido diana específico y que una vez alcanzado pueda permanecer en él, expresando su programa genético (Blocket y clos, 2005). En distintos modelos experimentales se ha comprobado que las MSC administradas vía sistémica son capaces de migrar hacia la localización donde se ha generado el daño tisular experimental consiguiendo la integración en dicha zona (Chapel y cols, 2003). Trabajos de Tomita y cols, 1999 o Wang y cols, 2000 han observado la capacidad de las MSC de médula ósea para injertar en el corazón infartado del ratón, así como para migrar hacia áreas de degeneración muscular (Ferrari y cols, 1998). También se ha observado la capacidad de las MSC de migrar a través de la arquitectura cerebral del huésped diferenciándose hacia astrocitos e incluso neuronas (Kopen y cols, 1999). Estos procesos de migración tienen distintas fases: en un primer momento se produce la adhesión celular al endotelio, en las que participan las integrinas presentes en la superficie de las MSC (Pittienger y cols, 1999). Acto seguido se produce la transmigración a través de la pared vascular y finalmente se produce la invasión del tejido dañado.

Existen distintas estrategias en el uso del tejido conectivo autólogo en relación a las distintas aplicaciones terapéuticas:

1. Evolución natural del tejido conectivo in situ. Estas estrategias se han diseñado para promover la formación del tejido dañado mediante la activación, proliferación y/o diferenciación del tejido a nivel local. El implante de un scaffold de tejido acelular (ya sea hueso alográfico, cerámicos, ácido hialurónico o polímeros sintéticos), es el mejor ejemplo de esta estrategia. El scaffold proporciona una superficie en el cual las células pueden soportarse y migrar formando un espacio hueco protegido en el que el nuevo 
tejido se puede formar y distribuir. Cuando estas propiedades promueven la formación del hueso hablamos de osteoconducción (Bauer y Muschler 2000; Fleming y cols, 2000). La liberación local de factores de crecimiento también sigue el curso celular natural; la capacidad de algunos factores de crecimiento para activar selectivamente la formación de hueso a partir del tejido conectivo local y el aumento de la probabilidad de que su descendencia celular se diferenciará a hueso es lo que hemos llamado osteoinducción.

La estimulación biofísica como las cargas mecánicas (Carter y cols, 1998; Turner y cols, 1998; Klein-Nulend y cols, 1995), la estimulación electromagnética (Aaron y cols 1996; Brighton y cols, 2001) o los ultrasonidos (Rubin y cols, 2001) son también un ejemplo de la evolución natural celular. Estrategias farmacológicas sistémicas u hormonas paratiroideas para el tratamiento de la osteoporosis (Lane y cols, 1998) o el uso sistémico de hormonas de crecimiento para aumentar la masa muscular (Hennesy y cols, 2001), son también distintos tipos de estrategias de ingeniería tisular basados en la curso natural de la fisiología celular.

2. Trasplante de tejido conectivo autólogo. Esta estrategia fue diseñada para compensar la deficiencia en el número o en la función del tejido del huésped, como puede ocurrir en regiones donde ha existido un trauma previo, infección, irradiación previa, defectos tisulares, cicatrices o compromiso vascular. El trasplante de tejido conectivo puede mejorar el resultado de la conducción e inducción de los injertos, incluso en situaciones en las que los defectos estén rodeados por tejidos no dañados (Muschler y Midura, 2002; Muschler y cols, 2003). El injerto de hueso autólogo ha sido durante mucho tiempo el más utilizado y el ejemplo más efectivo de trasplante celular, aunque solamente una pequeña fracción de la células trasplantadas sobrevivan (Burwell y cols, 1966; Burwell y cols, 1969). Muchos estudios clínicos como los de Garg y cols, 
1995 y 1993 y Healy y cols. en 1990, han sugerido que el aspirado de médula ósea sin procesar tienen un gran valor en su aplicación para la reparación ósea. En otros estudios controlados realizados por Cannolly y cols en 1989, encuentran la aplicación del aspirado de médula ósea exitosa en el tratamiento de fracturas de tibia. Cannoly y cols. en 1991 también demostraron que un concentrado de células de médula ósea obtenido mediante centrifugación puede aumentar rápidamente la osteogénesis, tesis que ha sido apoyada por numerosos autores.

Muchos cirujanos utilizan hoy en día médula ósea por su valor biológico y su bajo riesgo: apenas se producen casos de hematomas, infecciones o dolor crónico en el lugar de la aspiración; en ningún caso es la aspiración de médula ósea el motivo de la analgesia suministrada al paciente, la limitación de la rehabilitación, o la causa del retraso del alta hospitalaria. No obstante la técnica de aspiración es determinante. Además limitando el volumen de aspiración a $\leq 2 \mathrm{ml}$ por sitio, reduce la dilución con sangre periférica y aumenta considerablemente la concentración de las células progenitoras. Injertos óseos enriquecidos de este modo han mejorado significativamente los resultados en modelos de fusión espinal en perros (Muschler y cols, 2003) y han sido aprobados por la FDA en los injertos de hueso para fusión espinal y tratamiento de fracturas y defectos óseos.

3. Trasplante de células autólogas expandidas. El uso de células autólogas expandidas pueden contribuir a la formación del nuevo tejido (Bruder y cols. 1999; Caplan y Bruder, 2001). Los estudios preliminares sugieren que el cultivo expandido de células de músculo, grasa y médula ósea pueden ser útiles en la formación de hueso, cartílago, músculos y tendones (Kadiyala y cols, 1997; Bittira y cols, 2002; McKay y cols, 2000; McNiece y cols, 2001; Ringe y cols, 2002). La expansión celular ofrece un gran potencial para generar un alto número de células progenitoras, sin embrago, estos 
cultivos añaden un coste importante y algunos riesgos, como son la contaminación por bacterias o virus. Además dicha proliferación celulalar pueden provocar que las células presenten mutaciones o cambios epigenéticos que puedan conferir la potencial formación de tumores. Sin embargo, no se ha publicado la formación de ninguna masa tumoral en humanos a partir del uso de células expandidas en cultivo.

4. Trasplante de células modificadas genéticamente. El potencial biológico intrínseco del tejido conectivo puede ser modificado genéticamente con una variedad de medios, cada uno de los cuales puede, transitoria o permanentemente, alterar los genes que las células expresen. Los tejidos conectivos tienen la capacidad de segregar factores que influirán en el funcionamiento de las células. La introducción de nuevos genes o genes modificados se realiza, generalmente, por la modificación natural de virus como el retrovirus, lentivirus o adenovirus. Un ejemplo es el $L M P-1$, un factor de transcripción nuclear, proteína que cuando se expresa actúa sobre el núcleo activando o inhibiendo la expresión de un número determinado de otros genes. $L M P-1$ por lo tanto no se segrega, sino que actúa a nivel del núcleo celular, donde se expresa dicho gen, induciendo la secreción de una gran variedad de factores que puedan participar en la osteogénesis (Viggeswarapu y cols, 2001; Minamide y cols, 2003).

Los riesgos biológicos asociados a la manipulación genética son mucho mayores que en otras alternativas. A psear de ello, el trasplante de células modificas genéticamente puede ser una opción a tener en cuenta en un futuro en determinadas patologías, particularmente en defectos genéticos y hereditarios como por ejemplo la osteogénesis imperfecta (Prockop y cols, 1997) y en defectos en tejidos como el cartílago en que nos encontramos células de larga duración y relativamente homogéneas en las cuales, la expresión fenotípica puede inducir a un mantenimiento duradero por la expresión de un único gen (Parikh y cols, 2004; Porockop, 1997). 


\section{Trasplante de tejidos generados ex-vivo.}

La creación de un tejido totalmente organizado y maduro fuera del cuerpo seguido del trasplante funcional y su integración funcional es, a menudo, la visión pública más frecuente de ingeniería tisular. Sin embargo esta estrategia conlleva importantes retos:

- Generación de un tejido funcional.

- Trasplante de dicho tejido de modo que se mantenga la viabilidad y función celular.

- Fijación mecánica y biológica, así como su integración con el tejido que lo rodea.

En algunas áreas, el trasplante de finos injertos de tejido (piel, córnea, cartílago...) es posible sin la inmediata conexión a un sistema vascular desarrollado (Gallego y cols, 2010; Gravson y cols, 2015); sin embargo, en la mayor parte de los tejidos, la supervivencia de los mismos requiere un sistema vascular funcionante. Algunos autores describen la generación de sistemas de transporte vascular ex vivo, pero estas técnicas plantean numerosas dificultades en cuanto a su aplicación clínica (Griffith y cols, 1997; Kaihara y cols, 2000).

Independientemente del tipo de estrategia que se aplique, Meijer y cols. definieron en 2007, cuatro principios imprescindibles que se deben alcanzar para conseguir el éxito en terapia celular:

a. Un número apropiado de células con capacidad osteogénica. Las células ideales tienen que tener capacidad de renovación propia, ser fáciles de obtener y de expandir, así como mantener su fenotipo, función y capacidad de diferenciarse hacia aquel tipo de célula especializada y específica del tejido que se quiere regenerar, sin provocar respuesta inmune (Caplan y Goldberg 1999; Yang y cols, 2001; Muschler y cols, 2004). 
b. Matriz apropiada para la siembra de células. Se tiene que desarrollar un sistema que permita el transporte celular y de los factores de crecimiento, pero además tiene que tener unas características mecánicas, que le permitan su fijación al tejido (Bruder y cols, 1999).

c. Factores que estimulen la diferenciación osteogénica. Debido a que los factores de crecimiento juegan un papel imprescindible en los procesos de proliferación y diferenciación de los distintos tipos específicos de células (Cancedda y cols, 2003) y además mantienen su capacidad de rediferenciarse hasta el momento en que son transferidos desde el cultivo (Mainil-Varlet y cols, 2001).

d. Aporte vascular adecuado. Reece y Patrick, en 1998, consideran imprescindible, para asegurar la supervivencia y funcionalidad de las células, la creación de un lecho vascular que permita el aporte de oxígeno y nutrientes, así como la eliminación de todos los productos de deshecho, por tanto la falta de este aporte vascular va a producir la muerte inmediata de la célula, considerándose este hecho el motivo más frecuente de fracaso tras la terapia de ingeniería tisular en humanos (James y Steijn- Myagkaya, 1986).

\subsection{SOPORTE TRIDIMENSIONAL: SCAFFOLD}

El scaffold, que podríamos definirlo como la estructura tridimensional donde vehiculizamos las células, juega un papel crítico, tanto en el curso natural celular como en las distintas estrategias del trasplante celular. Los scaffolds sirven como un espacio en el huésped que permiten el crecimiento del tejido al interior de la zona del injerto, 
dotando de una superficie que facilita la inervación, supervivencia, migración, proliferación y diferenciación de las células madre y células progenitoras. Ofrece un volumen hueco donde se va a llevar a cabo la vascularización y formación de nuevo tejido. Además, el scaffold proporciona un vehículo para liberar células dentro del lugar del injerto, facilitando su retención y distribución donde el tejido es requerido.

Existe una gran variedad de scaffolds ya preparados para su uso clínico y otros muchos que están en pleno desarrollo. Las diferencias entre los distintos soportes, vienen dadas por las diferencias que podemos encontrar en sus características como es el tipo de material, la porosidad de su estructura, sus propiedades mecánicas o las propiedades químicas de su superficie

\subsubsection{TIPO DEL MATERIAL}

Existen distintos tipos de materiales que pueden utilizarse:

- Materiales derivados de tejidos: matriz de hueso, piel, submucosa intestinal...

- Polímeros biológicos: colágenos, fibrina, ácido hialurónico, alginatos... Desde hace poco tiempo se están empezando a desarrollar una variedad importante de polímeros sintéticos de tipo insoluble como son el ácido poliláctico, ácido poliláctico-poliglicólico, y varios copolímeros como gel sintético de polietilenóxido.

- Materiales cerámicos o minerales: fosfato tricálcico, hidroxiapatita, sulfato de calcio...

- Metales: titanio y otras aleaciones.

\subsubsection{ARQUITECTURA TRIDIMENSIONAL Y POROSIDAD}

La distribución en el espacio desde un punto de vista nano, micro o macroscópico es lo que denominamos matriz arquitectónica. Dicha matriz define la estructura mecánica del 
scaffold, pero sólo lo hace sobre el volumen inicial que está disponible para que las células en él presentes puedan formar nuevo tejido, incluidos vasos sanguíneos.

La mayor parte de los scaffolds están diseñados para tener una estructura interna porosa, con unos espacios huecos interconectados de estrechos canales que permitan la difusión de nutrientes, así como la eliminación de los desechos metabólicos producidos por la actividad celular. Esto adquiere más importancia en el tejido óseo ya que por sus características metabólicas, se producen altas tasas de transferencia, incluso in-vitro (Salgado y cols, 2004). El tamaño del poro oscila entre 50 a 1000 micras y el considerado ideal para conseguir un alto valor de crecimiento óseo varía entre $150 \mathrm{y}$ 500 micras (Tsuruga y cols, 1997), es decir un tamaño de poro que sea lo suficientemente grande como para permitir el crecimiento de tejidos vascularizados y suficientemente pequeño para estabilizar las células sin que éstas se desprendan. Los poros de gran tamaño generalmente soportan penetraciones profundas del nuevo tejido, pero el tamaño del poro ideal para conseguir un crecimiento profundo de $3-4 \mathrm{~mm}$ de tejido dentro del scaffold todavía no ha sido estudiado sistemáticamente. Todo esto tiene una gran importancia en el ámbito clínico, ya que el relleno de los grandes volúmenes con gránulos o materiales particulados, deja espacios entre dichas partículas que generalmente tienen un tamaño mayor que el tamaño del poro en la mayor parte de sus gránulos, lo cual puede influir en la revascularización profunda.

Las opciones para el diseño estructural de las matrices pueden ser infinitas: las macroestructuras nos permite contar con formas geométricas regulares, como bloques, esferas o barras; estructuras amorfas como gránulos o fibras empaquetadas aleatoriamente; o estructuras integradas aleatoriamente como las espumas. El gel y la pasta preparada pueden ser fabricadas también mediante la mezcla de polvo con agentes plásticos (glycerol, celulosa, ácido hialurónico...), o mediante la activación química, fotoquímica, o enzimática del polímero in situ. 
La mayor parte de los métodos de fabricación de los scaffolds crea una distribución de los volúmenes isotrópica y poros conectados entre sí (como una esponja), para conseguir estos poros se utilizan una serie de partículas o burbujas de manera que cuando el scaffold pasa a un estado sólido aparecen dichos huecos. En la década pasada se han producido importantes avances en los métodos de producción de microestructuras precisas en un gran número de materiales. Hoy día se aplican distintas opciones para crear canales y poros orientados estratégicamente, definiendo así su forma macroscópica. Las últimas innovaciones (procesos estereolitográficos) agrupan métodos de fabricación de estructuras que nos ofrecen una resolución del tamaño de hasta 200 micras. La creación de estructuras porosas perfectamente definidas ofrece el potencial necesario para tener un importante control sobre la distribución del volumen del material dentro del lugar del injerto, así como el control de los patrones de migración celular y su difusión a través de la estructura.

La característica nanoestructural (menor de 100 micras) juega también un papel muy importante en la función del scaffold. Los nanoespesores son demasiados pequeños para influir en que las células puedan o no migrar pero tienen un efecto importante en el comportamiento celular, a través del cambio en la textura superficial o difusión de los materiales solubles.

\subsubsection{PROPIEDADES MECÁNICAS}

En muchas ocasiones los lugares de injerto tienen que soportar de manera muy temprana altos niveles de cargas físicas. La fijación inicial proporciona a menudo la necesaria estabilidad primaria. Sin embargo, en muchas ocasiones, en determinados tipos de hueso o determinadas zonas de injerto, el scaffold debe soportar o por lo menos compartir importantes cargas de forma inmediata, y se requieren materiales y 
estructuras de alta resistencia como hueso cortical, metales, materiales cerámicos o materiales de fibra de carbono.

La regeneración y reparación ósea (que es un tejido duro y dúctil), requiere el uso de matrices elásticas que permitan su conservación en el espacio para el que han sido diseñadas, aportando por su parte al tejido el espacio necesario que permita su crecimiento (Brekke, 1996).

Las propiedades mecánicas del scaffold (dureza, elasticidad, fuerza y ductibilidad) están determinados tanto por el tipo de material como el tipo de estructura (macro, micro o nano). Las propiedades mecánicas del scaffold para conseguir el desarrollo del injerto son críticas para obtener un tejido sano. Las señales mecánicas son importantes mediadores en la diferenciación del tejido conectivo, por lo que el scaffold debe crear un ambiente de tensión adecuado en todo el lugar donde se desea la aparición del nuevo tejido. Uno de los mayores avaneces en el diseño de los scaffolds es el control de sus propiedades mecánicas a lo largo del tiempo. Uno de los problemas desde el punto de vista del diseño, es que para alcanzar esa fuerza que permita soportar transitoriamente las cargas, el material del que se compone la matriz debe tener un alto grado de unión interatómica e intermolecular, pero al mismo tiempo su estructura física y química debe permitir su descomposición hidrolítica. Los scaffolds no biodegradables como los metales o las cerámicas simplifican este problema y pueden proporcionar una excelente y duradera función en algunas localizaciones. Sin embargo, estos materiales pueden comprometer la reparación y la función del tejido, obviamente la persistencia del scaffold a lo largo del tiempo perjudica la formación de un nuevo tejido en el espacio que ellos ocupan. Además, la integración de un implante rígido no degradable, produce una serie de cambios locales en las señales mecánicas y pueden dar lugar a la pérdida del tejido local deseado. El estrés de la interfase entre las superficies del implante y el tejido propio pueden aumentar el riesgo de fracaso mecánico y dolor. Finalmente, si el 
proceso requiere la retirada del scaffold implantado (por ejemplo por infección o desplazamiento), todo el tejido nuevo formado junto al implante se perderá.

Todos estos problemas derivados de la permanencia de los scaffolds han llevado al desarrollo y al uso de matrices reabsorbibles, siempre y cuando sea posible. Pero las características de la degradación o procesos reabsortivos también pueden influir en el rendimiento:

- la matriz pierde sus propiedades mecánicas.

- La matriz puede ser desplazada de su sitio.

- La naturaleza y concentración de los productos solubles que son liberados en el lugar del injerto cuando el material se descompone. La liberación de subproductos, como los ácidos de degradación, causa reacción inflamatoria especialmente cuando el tejido circundante presenta una pobre vascularización o una actividad metabólica baja (Bergsma y cols, 1995; Böstmann y cols, 1990).

\subsubsection{PROPIEDADES QUÍMICAS DE LA SUPERFICIE}

La interacción entre las células y el scaffold se produce en la superficie del mismo y es el resultado directo del ambiente químico creado. La superficie química no solamente depende del tipo de material, ya que todos estos materiales son invadidos por distintas proteínas y lípidos y esta absorción de biomoléculas es el principal mediador de la respuesta celular. Variaciones en la absorción proteica pueden dar lugar a respuestas celulares muy distintas (Zeng y cols. 1999). Por tanto, cuando una proteína es absorbida, se somete a un cambio estructural, haciendo que se oculte o exponga en la superficie e interactúe con otros receptores celulares de superficie. Por ejemplo, la fibronectina es una molécula que presenta una mayor adhesión en superficies hidrofílicas como el vidrio que a superficies hidrofóbicas como el polietileno o teflón 
(Lewandowska K, Balachander N, 1989; Altankov G, 2000; Groth T, Altankov G, 1999). Los fluidos biológicos contienen una gran variedad de proteínas y las células tienen cientos de clases de receptores celulares de superficie. Por eso se está investigando concienzudamente las propiedades de absorción de las proteínas en las distintas superficies, haciendo grandes esfuerzos para entender por qué determinados materiales son más favorables para la adhesión de células óseas y la formación de hueso (Drobny GP, Long GR, 2003) dando de este modo, una gran relevancia a la selección del scaffold. Por ejemplo, se ha especulado que la hidroxiapatita y otros materiales cerámicos pueden captar preferentemente factores de crecimiento o moléculas de adhesión que son importantes para la regeneración ósea. En realidad, los materiales a base de hidroxiapatita y fosfato tricálcico actúan exitosamente como depósitos de vehículos liberados por las BMP tanto en animales (Uludag H, 2000), como en humanos (Boden SD, Kang J, 2002; Griffith LG, 2000).

Como otros materiales implantados, los injertos de matrices óseas (tanto mineralizados como no mineralizados) acumulan rápidamente biomoléculas en su superficie, las cuales tienen un efecto biológico sobre las células locales. Sin embargo, los injertos óseos, todavía contienen integradas varias moléculas de adhesión y factores de crecimiento (Hauschka y Mavrakos, 1986). Por lo tanto, el anclaje, la supervivencia, proliferación y diferenciación de las células implantadas puede ser modulada in vitro, si los implantes son preformados con una selección de proteínas bioactivas (Dennis y Caplan, 1993).

Por tanto, la matriz ideal debe cumplir una serie de requisitos:

1. Proporcionar un soporte físico para las células y permitir la disposición y crecimiento del nuevo tejido.

2. Aportar resistencia mecánica. 
3. Poseer una estructura porosa que permita la invasión vascular, que facilite la difusión de nutrientes y productos de deshecho celular (Salgado y Cols. 2004) y permita la migración celular a la zona del defecto para estimular el crecimiento del nuevo tejido.

4. Degradarse de forma controlada y predecible, sin generar residuos tóxicos, y que pueda eliminarse del organismo por vías naturales. La matriz debe tener una tasa de reabsorción igual a la neoformación ósea, de modo que cuando se ha producido la regeneración del tejido completo, la matriz debe haberse degradado en su totalidad (Salgado y cols, 2004; Logeart-Avramoglou y cols, 2005).

5. Biocompatibilidad, sin generar respuesta inflamatoria o inmunitaria significativa (Hutmacher y cols, 1996).

6. Ser esterilizable, sin comprometer sus propiedades.

\subsection{FACTORES DE CRECIMIENTO}

Representan, junto con las células y las matrices, el tercer pilar básico en la Ingeniería Tisular. Son elementos que tienen como finalidad la estimulación de la diferenciación osteogénica y son producidos por las propias células del huésped, pero también por las células incluidas en el injerto, actuando de este modo sobre ambos tejidos. Estos factores pueden ser añadidos a las matrices o depositados directamente en las zonas del defecto (Meyer y cols, 2004; Jiang y cols, 2006), aumentando el índice de proliferación celular y manteniendo la capacidad de diferenciación celular hasta el momento de su transmisión a un ambiente tridimensional (Jakob y cols, 2001). Algunos de estos factores son proteínas morfogénicas óseas (bone morphogenetic protein: BMP), factor de crecimiento tipo insulina (insuline-like growth factor: $I G F$ ), factor de crecimiento $\beta$ (transforming growth factor $\beta$ : TGF- $\beta$ ), factor de crecimiento fibroblástico (fibroblast 
growth factor: $F G F$ ), factor de crecimiento plaquetario (platelet derived growth factor: $P D G F)$. De todos estos factores merece mención especial las $B M P s$, ya que juegan un papel muy relevante en la inducción de formación de tejido óseo (Urist y cols, 1982). De todas las $B M P s$, son el tipo 2 y 7 las consideradas más inductivas (Jaldowiec y cols, 2003; Lind y cols, 2001; Yoon y cols, 2002), y aunque no se sabe con total exactitud el mecanismo por el que actúan sobre las $M S C$, sí se sabe que intervienen en la expresión de marcadores osteogénicos como son la fosfatasa alcalina o la osteocalcina (Gallea y cols, 2001). Mediante diferentes técnicas de biología molecular se pueden conseguir BMPs recombinantes humanas de los tipos 2 (rhBMP-2) y 7(rhBMP-7), que desde el año 2000 están aprobadas por la FDA para su utilización clínica por ejemplo en patología de la columna vertebral, y que en distintos estudios ya han demostrado, de forma evidente, el beneficio para los procedimientos de reparación ósea como es la reparación de defectos mandibulares llevadas a cabo en monos por Boyne (Boyne y cols, 1996 y 1998). 



\section{JUSTIFICACIÓN, HIPÓTESIS Y OBJETIVOS}





\section{JUSTIFICACIÓN}

Existe un gran número de situaciones patológicas hoy en día en que los tejidos óseos se encuentran afectados. Muchas de estas situaciones derivan de la atrofia de los maxilares, así como de procesos oncológicos, traumatológicos y congénitos que afectan al territorio maxilofacial, produciendo tanto graves alteraciones estéticas como funcionales.

La reconstrucción y rehabilitación de estos defectos que no son capaces de regenerarse por sí solos, constituyen hoy en día un reto que es abordado por una gran variedad de técnicas y procedimientos, y con el uso de un abanico muy amplio de materiales, que nos indica que todavía no se ha encontrado el sustituto óseo ideal, así como tampoco la técnica ideal; la distracción ósea (Ilizarov y cols, 1990), la dinámica axial de las fracturas en huesos largos (Richardson y cols, 1995), la ultrasonografía de baja intensidad (Hadjiargyrou y cols, 1998) o la estimulación eléctrica (Ryaby y cols, 1998) han aportado otras alternativas en los procesos de reparación ósea. No obstante la mejor técnica con la que contamos hoy en día es el uso de autoinjertos a partir de tejido óseo natural del propio paciente, ya que la biocompatibilidad del injerto, su potencial osteogénico y su resistencia mecánica nos asegura una mayor predictibilidad y rapidez en su consolidación (Taylor y cols, 1987). Por otro lado a pesar de ser ésta técnica ideal, no está exenta de limitaciones derivadas fundamentalmente de que la cantidad de injerto óseo donante que podemos obtener sin que se produzca un problema funcional es limitado. Además la reparación de defectos irregulares supone una problemática en cuanto a la adaptación del injerto en dichos defectos produciéndose frecuentemente procesos de reabsorción y no de curación. También se observa morbilidad posquirúrgica (Kurz y cols, 1989) derivada de posibles infecciones, fracturas, dolor y lesiones de 
estructuras adyacentes (daños nerviosos sensitivos y motores) tanto en la zona donante como en la zona receptora.

Por tanto, la justificación del presente trabajo de investigación viene dada por la necesidad de disponer de hueso autólogo, evitando los inconvenientes de los autoinjertos, obtenido mediante técnicas de cultivo in vitro. No solamente conseguir el cultivo de osteoblastos funcionales, sino la elaboración de una matriz tridimensional que permita el crecimiento celular en su interior, así como las condiciones de manipulación óptimas para su implantación en el defecto en animales de experimentación validando su utilidad clínica constituyen los retos de este trabajo.

\section{HIPÓTESIS}

El uso de una matriz tridimensional formada a partir de albúmina humana sembrada con células osteogénicas favorece el crecimiento y diferenciación de osteoblastos humanos mejorando la capacidad regenerativa de los defectos críticos óseos mandibulares en ratas atímicas.

\section{OBJETIVOS}

\subsection{OBJETIVO GENERAL}

Este trabajo está englobado en la línea de investigación iniciada por el Dr. Luís Miguel Redondo Gonález en el año 1993: "Biomateriales, reconstrucción y regeneración ósea 
cráneo mandibular, clínica y experimental" y continuada posteriormente por distintos miembros del Servicio de Cirugía Maxilofacial del Hospital Universitario Río Hortega de Valladolid, incorporando, en este caso, distintos procedimientos mediante el uso de técnicas de ingeniería tisular.

Pretende así mismo, continuar con la línea de investigación "Desarrollo mediante cultivo in vitro de osteoblastos mandibulares humanos sobre matriz proteica tridimensional. Análisis del comportamiento in vivo en animales inmunoincompetentes" iniciada por la Dra. Lorena Gallego en el año 2009 en la Universidad de Oviedo. En dicho estudio se lleva a cabo la diferenciación de células mesenquimales de hueso mandibular humano hacia células osteogénicas, las cuales son sembradas en una matriz proteica de albúmina obtenida a partir de suero humano, pretendiendo valorar su comportamiento in vivo en ratas atímicas, injertando dichas matrices en defectos críticos mandibulares. En este estudio realizamos una serie de variantes referidas a los procesos de diferenciación celular y al tiempo de cultivo celular en los scaffolds, analizando distintos grupos en los que se injertan matrices sin ningún tipo de cultivo, matices con células en medio de cultivo durante un día, matrices con células diferenciadas durante 21 días y matrices con cultivo celular de 21 días sin diferenciación.

\subsection{OBJETIVO PRINCIPAL}

Evaluar, desde un punto de vista radiológico e histológico, los procesos regenerativos en defectos criticos mandibulares de ratas inmunoincompetentes, estudiando las diferencias finales existentes entre los distintos tipos de injerto según el tiempo de cultivo y diferenciación celular dentro de las matrices, comparando los distintos grupos con el grupo control y los distintos grupos entre sí. 


\subsection{OBJETIVOS ESPECÍFICOS}

1. Desarrollo y validación de un modelo animal en investigación básica para el estudio de regeneración ósea mediante el uso de técnicas de ingeniería tisular.

2. Determinar la validación de una matriz tridimensional de elaboración autóloga que favorezca el crecimiento y diferenciación de osteoblastos humanos.

3. Evaluar el comportamiento de los injertos cuando éstos son colocados de forma ectópica alejados de tejido óseo del receptor, en este caso a nivel subcutáneo inguinal y en la proximidad de un pedículo vascular

4. Desarrollar y validar un protocolo para el análisis comparativo de las densidades óseas mediante la utilización del programa Osiri $X^{\circledR}$ para Macintosh $®$. 


\section{MATERIAL Y MÉTODO}





\section{MATERIAL}

\subsection{ANIMAL EXPERIMENTAL}

El modelo experimental utilizado fue la rata (ilustración 8):

Orden: Rodentia

Suborden: Myomorpha

Familia: Muridae

Género/Especie: Rattus novergicus

Ilustración 8. Imagen de rata mutante atímica desnuda

Existen más de 50 cepas no consanguíneas y más de 400 consanguíneas definidas genéticamente. La cepa utilizada fue la $\operatorname{HsdHan}^{\mathrm{TM}}: \mathrm{RNU}-F_{0 x n}{ }^{r n u}$, animales suministrados por Harlan Laboratories.

La rata mutante atímica desnuda (athymic nude mutante rat) procede de una colonia no consanguínea de ratas del Instituto de Investigación Rowett, Aberdeen, Escocia en la que se descubrió la mutación rnu en 1953.

Actualmente las características de la rata mutante atímica desnuda las convierte en modelo de utilidad en muchas líneas de investigación y son adecuadas para investigación del trasplante, tratamiento y estudio de tumores, carcinogénesis, xenotrasplantes y muchos otros propósitos. 
Características de la rata atímica desnuda (ilustración 9-12) (Cook y cols, 1995;

Festing y cols, 1978; Rygaard y cols 1987; Vos y cols, 1980; Suckow y cols, 2006):

- Aplasia del timo.

- Reducción de las poblaciones celulares en áreas timodependientes de órganos linfoides periféricos.

- Presenta una deficiencia en células T.

- Función normal en células B
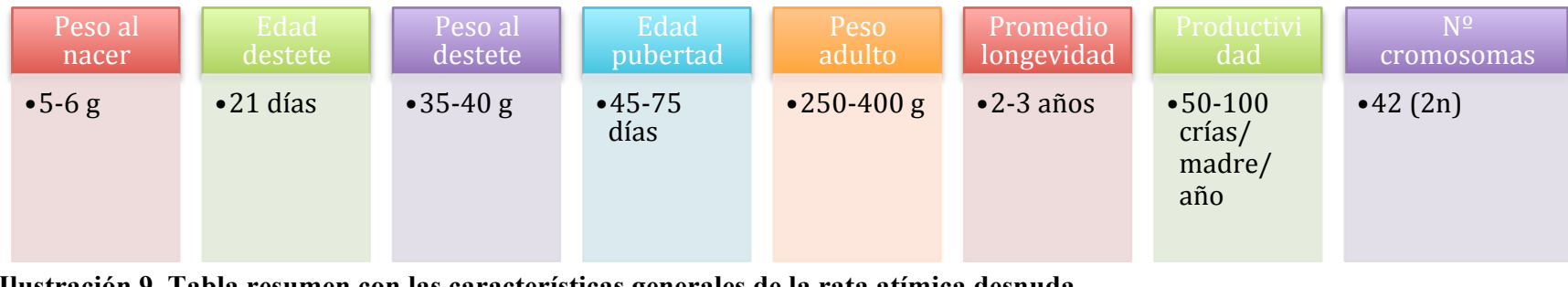

Ilustración 9. Tabla resumen con las características generales de la rata atímica desnuda.
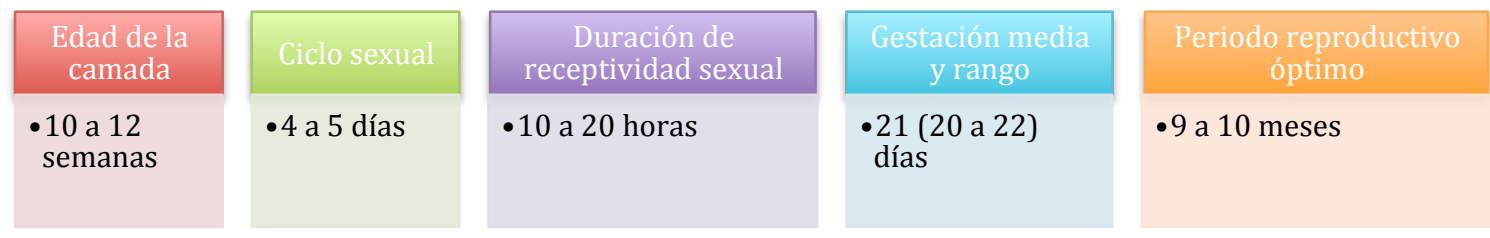

Ilustración 10. Tabla resumen con datos de cría y reproducción de la rata atímica desnuda.
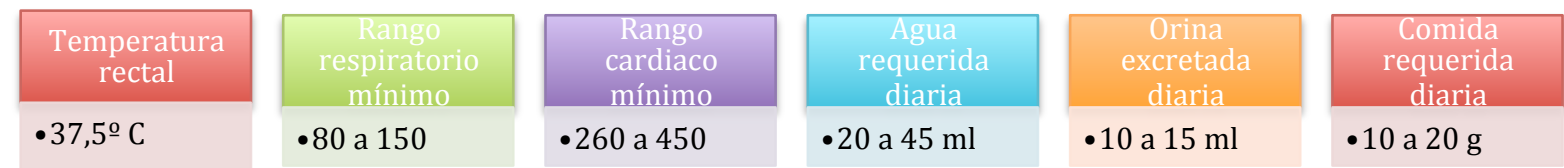

Ilustración 11. Tabla resumen con parámetros fisiológicos y nutricionales de la rata atímica desnuda. 


\begin{tabular}{|c|c|}
\hline Esperanza de vida usual & •2,5-3 años \\
\hline Esperanza de vida máxima & • 4 años y 8 meses \\
\hline Área superficie & $\bullet 0.03-0.06 \mathrm{~cm} 2$ \\
\hline Consumo de agua & •80-110 ml/Kg/día \\
\hline Apertura de ojos & •10-12 días \\
\hline Frecuencia cardiaca & -330-480 latidos/minuto \\
\hline Presión arterial sistólica & $\bullet 80-184 \mathrm{mmHg}$ \\
\hline Presión arterial diastólica & •58-144 mmHg \\
\hline Gasto cardiaco & -50(10-80)ml/minuto \\
\hline Volumen sanguíneo & $\begin{array}{l}\text {-Plasma: } 40.4(36.3-45.3) \mathrm{ml} / \mathrm{Kg} \\
\text {-Sangre completa: } 64.1(57.5 / 69.9) \mathrm{ml} / \mathrm{Kg}\end{array}$ \\
\hline Frecuencia respiratoria: & • $85.5(66-114) /$ minuto \\
\hline Volumen tidal & $\bullet 0.86(0.6-1.25) \mathrm{ml}$ \\
\hline Volumen minuto & $\bullet 0.073(0.05-0.101) \mathrm{ml}$ \\
\hline Volumen de eyección & •1.3-2.0 ml/latido \\
\hline
\end{tabular}

Ilustración 12. Tabla resumen con datos fisiológicos de rata atímica desnuda.

La primera observación de ratas desnudas mutantes fue en 1953 en el Rowett Research Institute, en Inglaterra. Una colonia de estas ratas fue mantenida durante algunos años hasta que desapareció en los años sesenta, pero sin embargo el gen recesivo responsable de este fenotipo no desapareció, y consiguió mantenerse bajo otros genes frecuentes en estas colonias de ratas, hasta que se recuperó en 1975 mutaciones homocigóticas. La denominación de estas ratas se llamó Rowett nude rat (rnu) y el gen recesivo: rnu (Festing y cols, 1978).

Aproximadamente en la misma época surgió de modo totalmente independiente una mutación muy similar en una colonia de ratas albinas criadas en Nueva Zelanda, que se denominaron New Zelland nude rats y su gen: nznu (Berridge y cols, 1979). El control de la expresión de los genes recesivos de estas mutaciones en rnu/rnu y nznu/nznu son 
presumiblemente alélicos, pero sus fenotipos son ligeramente diferentes ya que estas ratas son totalmente desnudas, mientras que las ratas $r n u$ muestran un débil crecimiento de pelo temporalmente.

Las ratas $r n u$ acumulan también células con marcadores de células $\mathrm{T}$ a medida que envejecen. Sin embargo ambos tipos de ratas n-mutantes tienen una similitud muy importante al ratón desnudo atímico, ambos presentan una marcada deficiencia de células T maduras y tienen un gran defecto en las respuestas inmunes de los mediadores de células T (Fossum y col, 1980; Brooks y cols, 1980).

La deficiencia de estas células $\mathrm{T}$ en ratas atímicas desnudas, han sido ampliamente explicadas para el estudio del crecimiento tumoral (Kjonniksen y cols, 1989; Kjonniksen y cols, 1990; Storeng y cols, 1991) así como para el estudio de la aceptación de alo/xeno-trasplantes en animales inmunoincompetentes. (Ford y cols, 1983; Sarawar y cols, 1991; Bradley y cols, 1992).

Toda la experimentación animal realiza en este trabajo de tesis doctoral se ha llevado a cabo conforme a todas las disposiciones vigentes en cuanto a la utilización de animales en investigación u otros fines científicos:

- Ley 32/2007, de 7 de noviembre, para el cuidado de los animales, su explotación, transporte, experimentación y sacrificio.

- Real Decreto 1201/2005, de 10 de octubre, sobre protección de los animales utilizados para experimentación y otros fines científicos.

- Real Decreto 664/1997, de 12 de mayo, sobre la protección de los trabajadores contra los riesgos relacionados con la exposición a agentes biológicos durante el trabajo. 
- Directiva Europea de 1986 (86/609/CEE), sobre protección de animales vertebrados utilizados con fines experimentales y otros fines científicos.

\subsection{INSTALACIONES}

Este trabajo ha sido realizado gracias a los medios técnicos y humanos de los siguientes departamentos:

- Servicio de Investigación y bienestar animal de la Facultad de Medicina de la Universidad de Valladolid.

- Instituto de Genética y Biología Molecular (IBGM) de Valladolid.

- Servicio Regional de Cirugía Oral y Maxilofacial del Hospital Universitario Río Hortega de Valladolid.

- Unidad de Metabolismo Óseo y Mineral del Hospital Universitario Central de Asturias.

- Servicio de Radiología del Hospital Universitario Río Hortega de Valladolid.

- Servicio de Anatomía Patológica del Hospital Universitario Río Hortega de Valladolid.

- Unidad de apoyo a la investigación del Hospital Universitario Río Hortega de Valladolid. 


\subsection{INSTRUMENTAL Y MATERIALES}

\subsubsection{INSTRUMENTAL QUIRÚRGICO}

- Mango de bisturí metálico Brand Parker con hojas de acero de distinta numeración ( $\left.\mathrm{n}^{\mathrm{o}} 11 \mathrm{y} \mathrm{n}^{\mathrm{o}} 15\right)$.

- Pinzas de disección tipo Adson con y sin dientes.

- Pinzas hemostáticas finas de Hasrtmann, rectas y curvas.

- Desperiostizadores, fino y mediano.

- Separadores autorretentivos de Adson-Baby.

- Tijera de disección.

- Tijera vascular.

- Tijera quirúrgica de Mayo.

- Portaagujas de Mayo con cremallera.

- Pinzas de disección microquirúrgica.

- Jeringa tipo carpule con agujas de 13/16"

- Sutura reabsorbible de Vicryl de 4/0 y 5/0 (poliglactina 910).

- Fresas redondas de 2 y $4 \mathrm{~mm}$ de diámetro externo.

- Equipo NSK para cirugías de implantes dentales con sistema de irrigación incorporado.

- Contraángulo quirúrgico NSK.

- Lentes de aumento Sheer Vision 250-R.

- Almohadilla térmica. 


\subsubsection{FÁRMACOS}

\subsubsection{ANESTÉSICOS:}

- Sevoflurano (fluorometil 2,2,2-trifluoro-1 [trifluorometil]etil éter). Sevo Rane $®$ (ilustración 13).

- Clorhidrato de Ketamina (75 mg por Kg). Ketolar $®$ (ilustración 13).

- Xilacina (10 mg por Kg de peso) (ilustración 13).

- Articaína con vasoconstrictor (40 mg por Kg de peso). Ultracain ${ }^{\circledR}$.

- Éter.

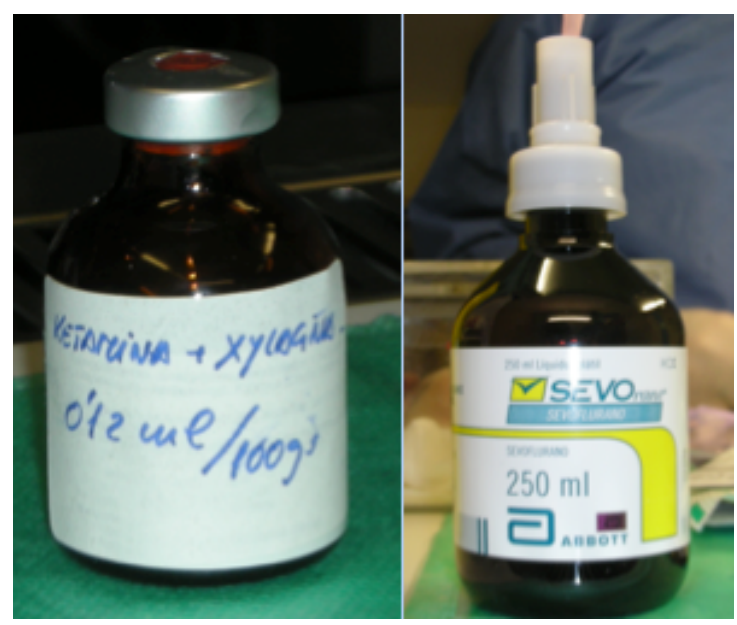

Ilustración 13. Anestesia infiltrativa e inhalatoria utilizada en el procedimiento.

\subsubsection{FÁRMACOS POSTOPERATORIOS:}

- Endofloxacina oral en agua de bebida: $10 \mathrm{ml}$ de Baytril ${ }^{\circledR}$ 0,5\% solución oral por litro de agua.

\subsubsection{MATERIAL PARA EL PROCESAMIENTO HISTOLÓGICO.}

- Formol al 10\% tamponado.

- Soluciones de procesado de tejido: alcoholes, xileno, formalina, parafina.

- Soluciones para la tinción de tejidos: hematoxilina de Hasrris, eosina Y. 
- Microscopio Nicon Alphaphot 2YS2 (x40, x100, x400).

- Cámara fotográfica Nikon FX-35 WA adaptada al microscopio.

- Talladora TM-60 de bloques de resina.

- Ultramicrotomo LKB-Ultratome V.

\subsubsection{PROCESAMIENTO DEL MATERIAL BIOLÓGICO:}

- Citómetro de flujo Becton-Dickinson.

- Campana e incubadora de cultivo.

- Centrifugadora refrigerada.

- Equipo histológico básico con vibratomo y criotomo.

- Solución salina balanceada de Hank (HBSS).

- Suero fetal bovino al 10\% (Sigma-Aldrich, St. Lois, MO)

- Medio de cultivo Dulbecco (Dulbecco's modified Eagles Medium, DMEM) (Gibco-BRL, Paesley, UK).

- Solución antibiótica-antimicótica para medios de cultivo al 1\% (Life Technologies).

- Colagenasa A tipo I 1mg/ml (Roche Molecular Biochemicals).

- Tripsina al 0,25\% con 1mM de EDTA (Gibco- BRL, Paisley, UK).

- Solución de fibronectina $(100 \mathrm{mg} / \mathrm{ml})$ (Collaborative Biomedial Products; Collaborative Research Inc., Bedford, MA, USA).

- Suero fisiológico.

- Jeringas de $20 \mathrm{ml}$.

- Agujas de $20 \mathrm{G}$.

- Placas de Petri de $35 \mathrm{~mm}$.

- Tubos cónicos. 
- Insert Falcon (Becton-Dickenson, San José, CA, USA).

- Placas de cultivo de tampón ventilado de 25 y 75 cc.

- Ácido ascórbico (Sigma, St. Lois).

- Glicerofosfato (Sigma, St Lois).

- Dexametasona (Acidexam; Aciphar, Bruselas, Bélgica).

- Glucosa (Gibco- BRL, Paisley, UK).

- Glutamina (Gibco- BRL, Paisley, UK).

- Suero Salino Búfer-Fosfato (PBS) (Life Technologies).

- Cloruro de amonio (Sigma, St Lois).

- Pipetas Pasteur.

- Bisturí no 42.

\subsubsection{MATERIAL PARA EL PROCESADO RADIOLÓGICO:}

- TAC Multicorte: Siemens ${ }^{\circledR}$

- Platafoma OsiriX versión 3.5.1 para Macintosh ${ }^{\circledR}$.

\subsubsection{MATERIAL PARA EL ESTUDIO ESTADÍSTICO:}

- Programa SPSS 15.0 para Macintosh $\mathbb{R}$.

- Ordenador personal MacBook Air de Macintosh $®$, os $X$ versión 10.5.8.

\subsubsection{MATERIAL FOTOGRÁFICO:}

- Cámara fotográfica Reflex Canon EOS 500. 


\section{MÉTODO}

\subsection{OBTENCIÓN DE LA MUESTRA ÓSEA}

La muestra ósea se obtuvo a partir de esponjosa mandibular de 6 pacientes diferentes durante la exodoncia profiláctica de cordales incluidos inferiores (ilustración 14). Las edades de los pacientes estaban comprendidas entre los 20 y 32 años, siendo la edad media de los mismos de 25 años con una misma representación de ambos sexos (3 varones y 3 mujeres). Los pacientes no presentaron antecedentes clínicos de patologías óseas primarias u otras patologías que pudieran afectar al metabolismo del hueso, ni consumían drogas o fármacos que pudieran afectar al mismo. Los niveles séricos de creatinina, fosfatasa alcalina, urea y calcio de los pacientes se encontraban en unos niveles normales.

Todos los pacientes fueron intervenidos en la consulta de cirugía Oral del Servicio Regional de Cirugía Oral y Maxilofacial del Hospital Universitario Río Hortega de Valladolid, bajo anestesia locorregional y en condiciones de asepsia. 


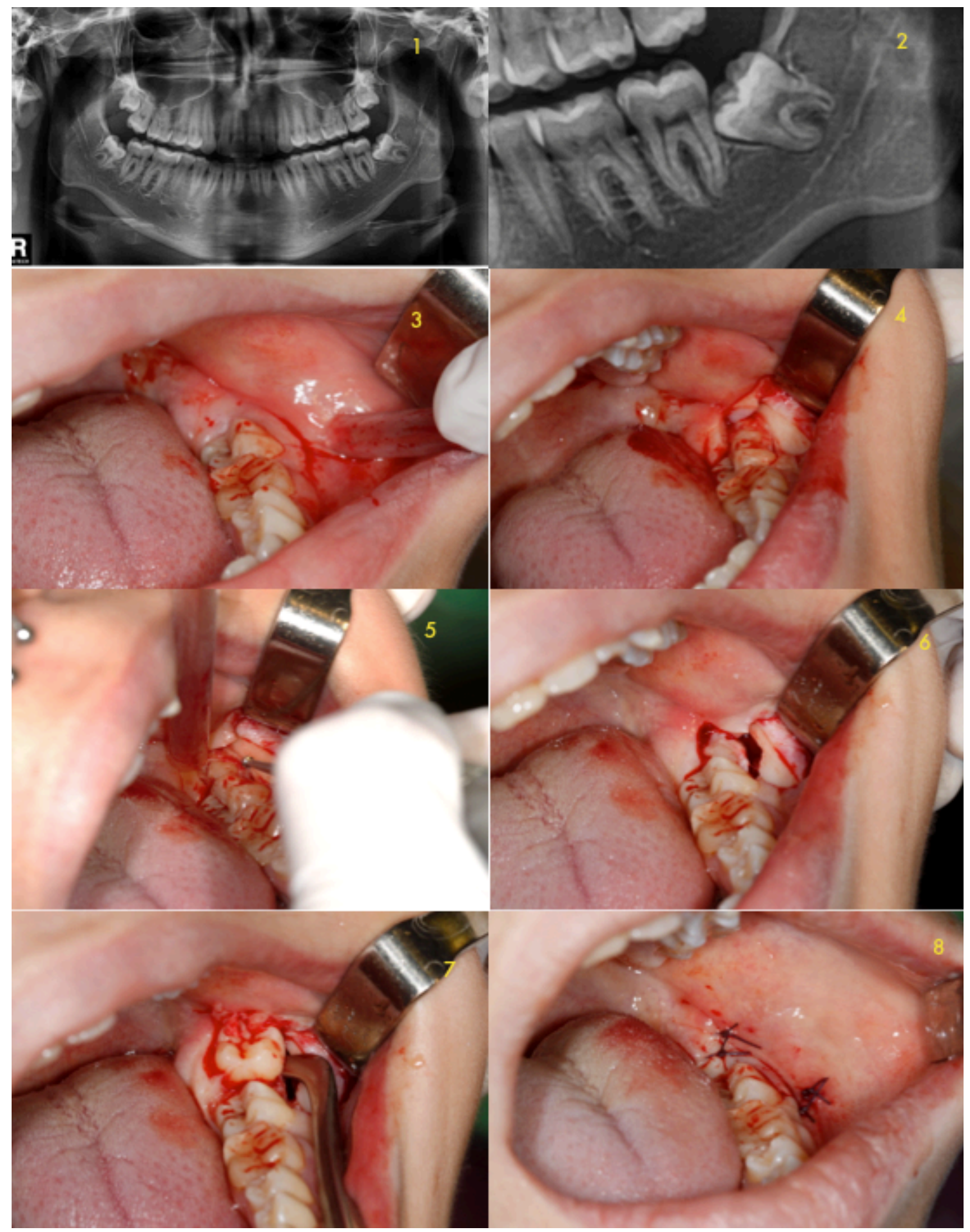

Ilustración 14. Proceso de extracción del fragmento óseo durante la exodoncia de cordal inferior izquierdo. Estudio radiológico mediante ortopantomografía para la planificación de la cirugía (1 y 2). Incisión para la realización de colgajo mucoperióstico de espesor total para el acceso al cordal (3 y 4). Realización de ostectomía con fresa redonda y con irrigación, donde procedemos a la retirada de pequeños fragmentos óseos (5 y 6). Extracción del tercer molar y cierre de la herida quirúrgica (7 y 8 ). 


\subsection{MANIPULACIÓN DE LAS MUESTRAS}

Obtuvimos muestras de pequeños fragmentos óseos corticoesponjosos de entre 1 y 3 mm de diámetro durante la ostectomía llevada a cabo durante la cirugía de exodoncia de los cordales incluidos mandibulares (ilustración 14). Dichos fragmentos se introdujeron inmediatamente en falcón estéril de 50 cc con medio de recogida compuesto por RPMI + antibióticos y antimicóticos (penicilina, estreptomicina y fungizona) y fueron transportados de inmediato al IBGM (Instituto de Genética y Biología Molecular) de Valladolid, donde se conservaron a $4^{\circ} \mathrm{C}$ durante toda la noche.

\subsection{PROCESAMIENTO DE LAS MUESTRAS}

\subsubsection{CULTIVOS}

Obtenida la muestra la colocamos una placa de Petri estéril de $35 \mathrm{~mm}$ de diámetro y con ayuda de un bisturí del $\mathrm{n}^{\mathrm{o}} 42$ (Kennel, China) troceamos la muestra lo más finamente posible. Los explantes obtenidos fueron sometidos a un lavado de 30 minutos en Tripsina/EDTA (Gibco) a $37^{\circ} \mathrm{C}$ en agitación constante para eliminar los restos de células hematopoyéticas. Para llevar a cabo este proceso, introdujimos todos los fragmentos en un falcón estéril con $15 \mathrm{ml}$ de Tripsina/EDTA y lo colocamos en el agitador orbital a $150 \mathrm{rpm}$ durante 30 minutos. Pasado este tiempo centrifugamos 10 minutos a $1400 \mathrm{rpm}$ y eliminamos la Tripsina/EDTA, quedando en el fondo del falcón los explantes de la muestra.

Los explantes obtenidos se siembran en un frasco de cultivo de $25 \mathrm{~cm}^{2}$ con $4 \mathrm{ml} \mathrm{de}$ medio de cultivo DMEM (Dulbecco's Modified Minimal Esencial Médium), 10\% FBS y $1 \% \mathrm{P} / \mathrm{E}(100 \mathrm{UI} / \mathrm{ml})$. El cultivo se realiza en el incubador a $37^{\circ} \mathrm{C}$ y $5 \% \mathrm{CO}_{2}$. El medio de cultivo se renueva dos veces a la semana durante dos semanas. 
Pasado este tiempo, el frasco de cultivo esta confluente, es decir, tiene toda la superficie ocupada por células.

Cuando el frasco de cultivo está confluente, retiramos el medio de cultivo, se tratan las células con $4 \mathrm{ml}$ de Tripsina/EDTA durante 10-15 minutos, tiempo necesario para que las células se despeguen del frasco y se individualicen. A continuación, con una pipeta Pasteur se recoge la suspensión de células en Tripsina/EDTA, se neutraliza con $4 \mathrm{ml}$ de medio de cultivo y se centrifugan 10 minutos a $1400 \mathrm{rpm}$. De esta forma, se obtiene un pellet que contiene las células, principalmente osteoblastos.

Las células obtenidas se resuspenden en $5 \mathrm{ml}$ de medio de cultivo, se cuentan en la cámara de Neubauer y siembran en un flask de $75 \mathrm{~cm}^{2}$. Este paso nos permite obtener un mayor número de células en cultivo y se repite hasta obtener el número de células necesario para sembrar en el scaffold.

Tras tres semanas de cultivo, se obtiene el número suficiente de células para sembrar en la matriz.

\subsubsection{DESARROLLO DE LA MATRIZ PROTEICA (SCAFFOLD)}

La matriz es un soporte tridimensional de naturaleza proteica, el cual se puede fabricar con material autólogo. Para la preparación de dicho soporte, se recogieron $10 \mathrm{ml}$ de sangre humana, procedente del Centro Comunitario de Sangre y Tejidos del Principado de Asturias.

La muestra se mantuvo a $37^{\circ} \mathrm{C}$ durante 30 minutos para producir la retracción del coágulo de fibrina. Inmediatamente después se procede a la centrifugación a $3000 \mathrm{rpm}$ durante 15 minutos. Se obtienen $5 \mathrm{ml}$ de suero que es cruzado con $0,5 \mathrm{ml}$ de glutaraldehido al $25 \%$, transfiriendo la mezcla resultante a una jeringa de $5 \mathrm{ml}$ (ilustración 15). 
Se mantiene la muestra 30 minutos a temperatura ambiente hasta alcanzar un estado de solidificación. Posteriormente se introduce en el congelador manteniéndose toda una noche a $-80^{\circ} \mathrm{C}$. Tras el periodo de congelación se corta la jeringa, liberando el cilindro del scaffold. Después se liofiliza la solución congelada y se rehidrata en etanol en concentraciones descendentes (100-90-80\%), manteniéndose durante una hora en cada una de dichas concentraciones.

De esta manera obtenemos un cilindro de consistencia esponjosa que se fragmenta en láminas de $2 \mathrm{~mm}$ de sección cada una. Estas láminas son esterilizadas durante 8 horas en una solución de etanol al 70\%.

A esta matriz la hemos denominado en este trabajo scaffold Meana por el investigador principal que desarrolló dicha matriz el Dr. Álvaro Meana Infiesta (Meana y cols, 2010).
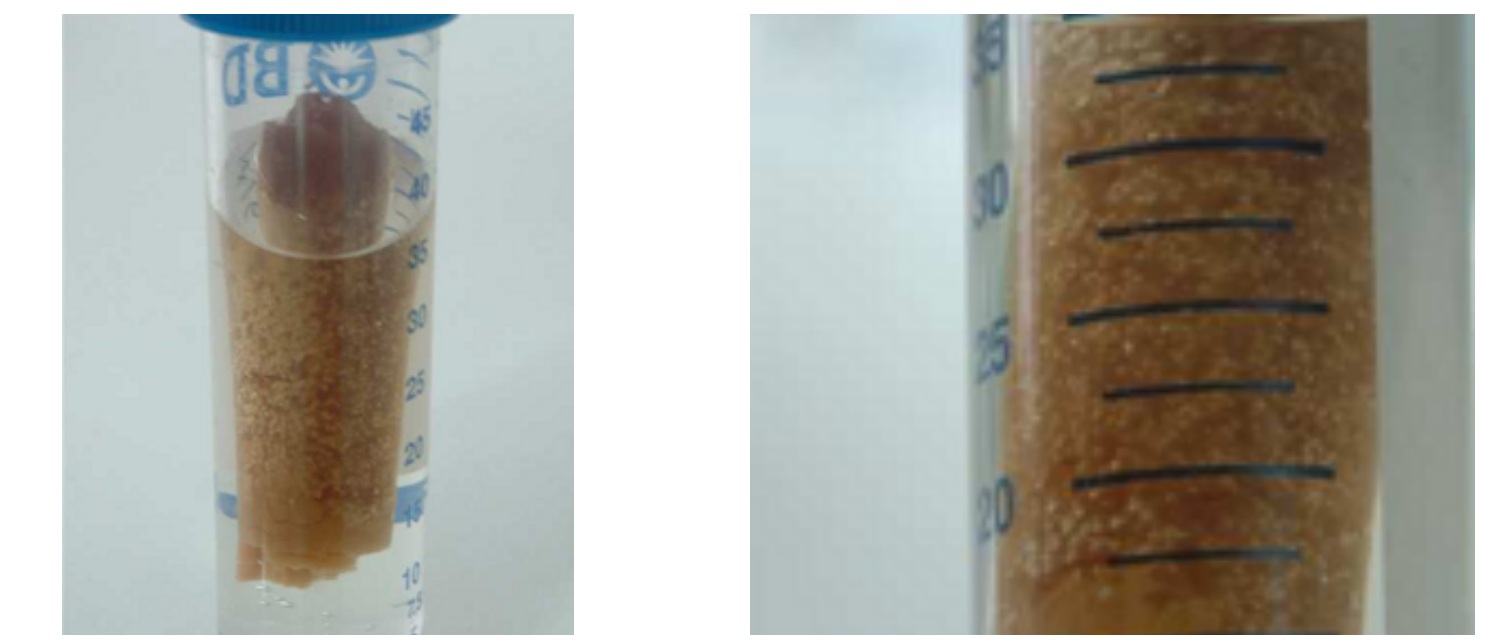

Ilustración 15. Matriz proteica preformada con forma de cilindro para facilitar su posterior implantación en el defecto durante el acto quirúrgico.

\subsubsection{CULTIVO COMBINADO DE CÉLULAS Y MATRIZ}

Una vez obtenido el numero suficiente de células, se resuspende en $10 \mathrm{ml}$ de medio de cultivo y procedemos al contaje celular en cámara de Neubauer. Dividimos las células obtenidas en tubos Ependorff a una concentración de 350000 celulas por cada tubo, número de células necesarias para cada matriz. Centrifugamos nuevamente a $1400 \mathrm{rpm}$ 
durante 10 minutos. El pellet obtenido se resuspende en $100 \mu 1$ de medio de cultivo y se siembra en la matriz, dejando en agitación suave durante 24 horas a $37^{\circ} \mathrm{C}$ en incubadora. A partir de aquí vamos a establecer los grupos de nuestro experimento en función de la combinación células/matriz y medio de diferenciación utilizado para el cultivo (ilustración 16). De este modo formamos estos grupos:

- Matrices traspalantadas tras 24 horas tras la siembra.

- Matrices trasplantasdas sin células tras 24 horas en medio de cultivo.

- Matrices con células cultivas 21 días en medio osteogénico (DMEM (Gibco), 10\% FBS (Gibco), Dexametasona $10 \mathrm{nM}$ (Sigma), $\beta$-Glicerol Fosfato $10 \mathrm{nM}$ (Sigma), Ácido Ascórbico $0.28 \mathrm{nM}$ (Sigma) y $1 \% \mathrm{P} / \mathrm{E})$.

- Matrices con células cultivadas durante 21 días con medio de cultivo de células mesenquimales DMEN + 10\% FBS.

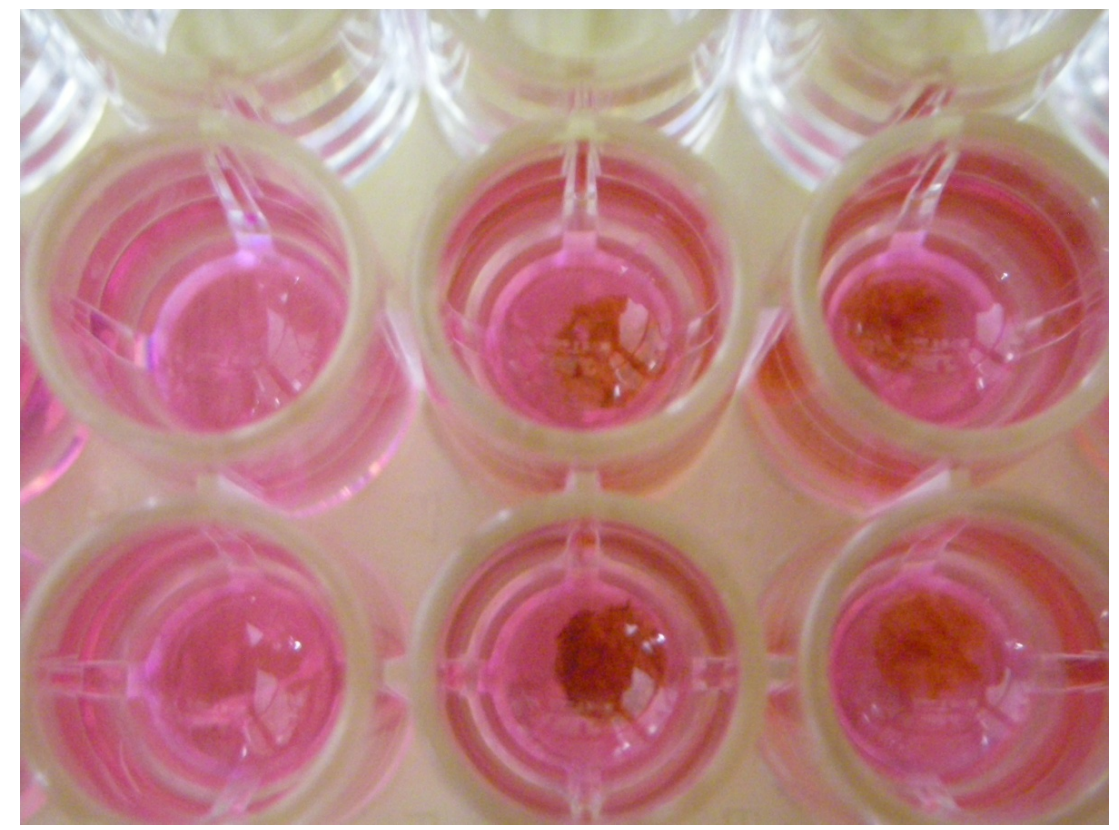

Ilustración 16. Aspecto de las matrices cortadas en secciones finas de $4 \mathrm{~mm}$ de diámetro preparadas para su implantación .

Para la siembra de las células en el interior de las matrices hemos seguido los protocolos establecidos por la Dra. Gallego en el año 2009 descritos en su trabajo de su tesis doctoral: "Desarrollo mediante cultivo in vitro de osteoblastos mandibulares humanos 
sobre matriz proteica tridimensional. Análisis del comportamiento in vivo en animales inmunoincompetentes", siguiendo estos protocolos podemos asegurar que en dichas matrices existen células en su interior. La comprobación de que las células están insertadas en la matriz se realiza mediante estudios histológicos (tinción HematoxilinaEosina y tinción de Von Kossa) (ilustración 17, 18), análisis inmunohistoquímico (expresión de fosfatasa alcalina) (ilustración 19) y con el estudio mediante microscopía electrónica (ilustración 20, 21).

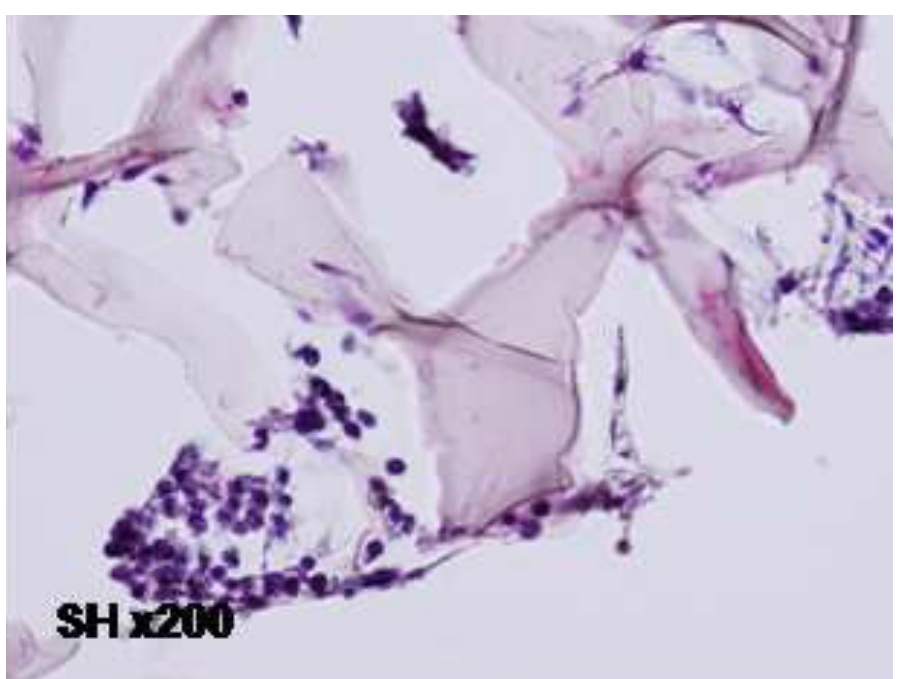

Ilustración 17. Estudio mediante tinción H-E del comportamiento in vitro de osteoblastos sobre la matriz. (Gallego, 2009)

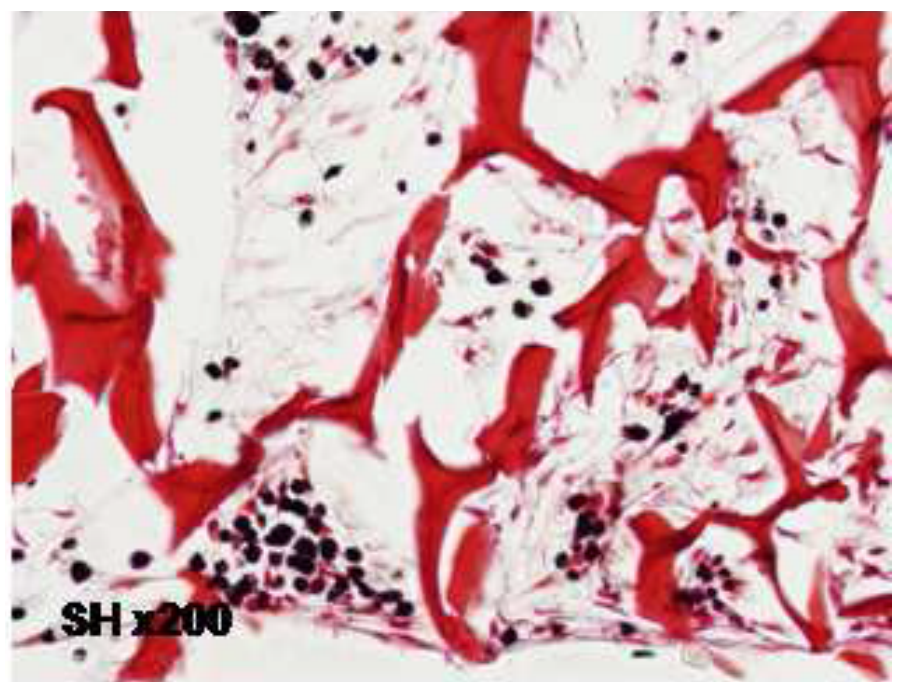

Ilustración 18. Estudio mediante tinción de VK del comportamiento in vitro de los osteoblastos sobre la matriz con depósitos negros correspondientes a la matriz mineralizada (Gallego, 2009). 


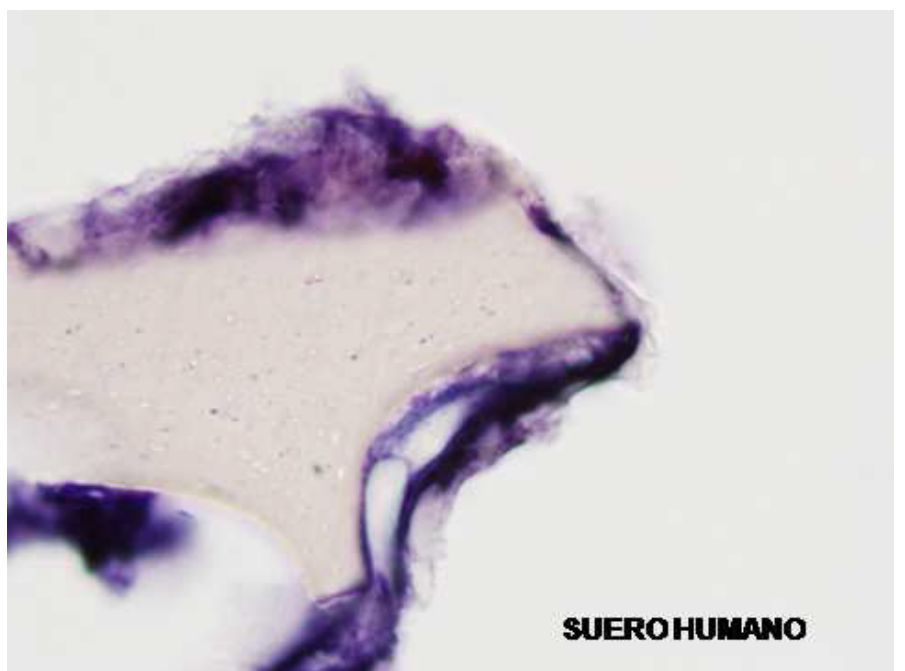

Ilustración 19. Actividad de FS in vitro de la matriz. (Gallego, 2009).

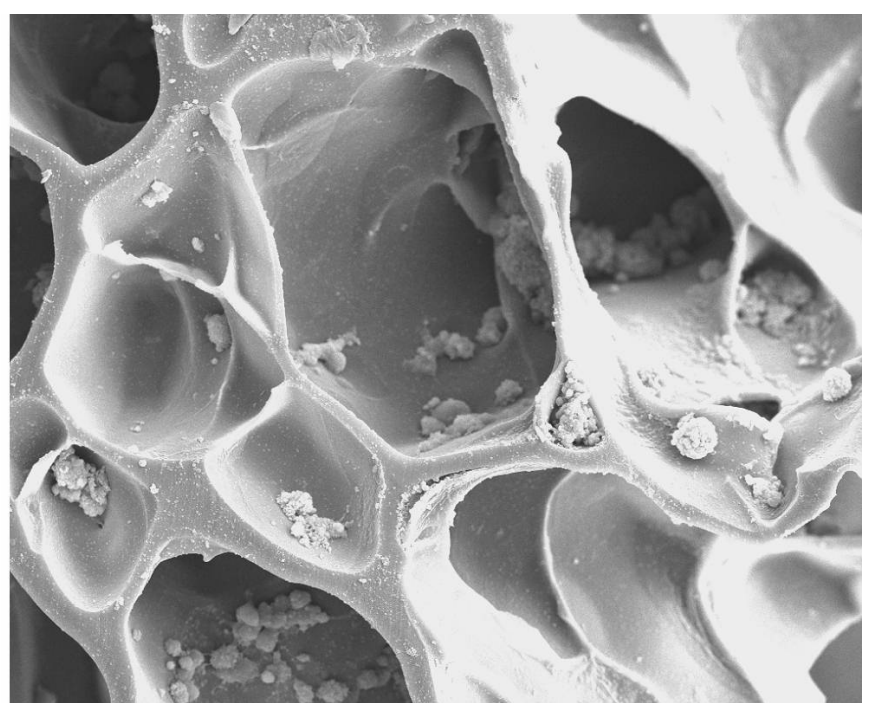

Ilustración 20. Imagen a 300 aumentos de microscopía electrónica de barrido donde se aprecia la porosidad de la matriz y la ocupación por osteoblastos (Gallego, 2009).

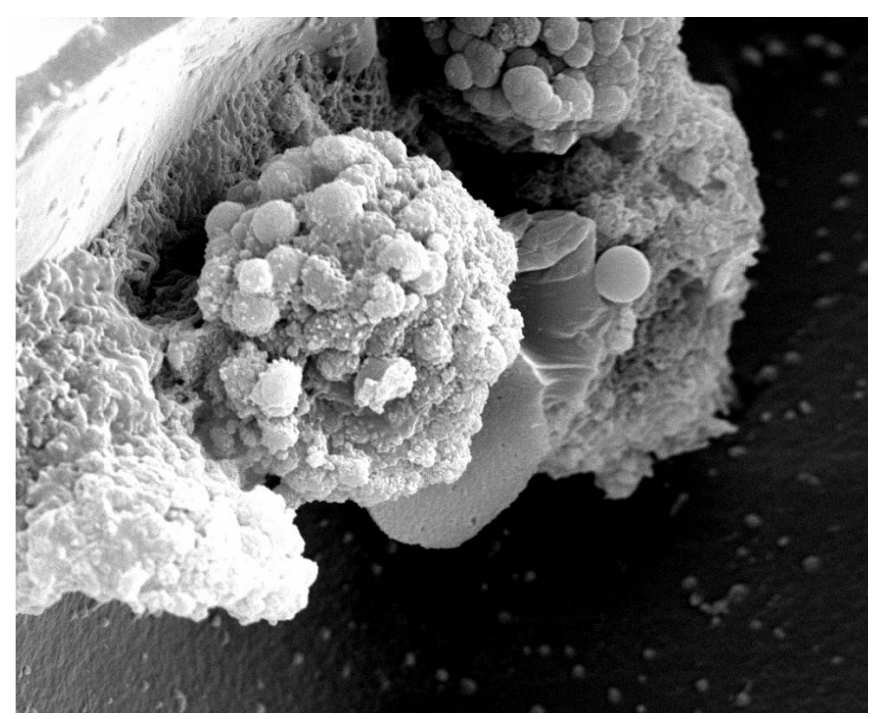

Ilustración 21. Detalle a mayor aumento (x2700) donde apreciamos los conglomerados de osteoblastos (Gallego, 2009). 


\subsection{FASE DE IMPLANTACIÓN DEL INJERTO}

\subsubsection{DISTRIBUCIÓN DE LOS GRUPOS}

El conjunto de los animales formaban un total de 12 especímenes, los cuales los distribuimos en 2 grupos distintos y cada grupo en 2 subgrupos correspondientes dichos subgrupos a cada hemimandíbula del animal (ilustración 22). De este modo pudimos llevar a cabo un estudio de 4 grupos distintos, obteniendo de cada grupo 6 muestras diferentes. Los distintos grupos los distribuimos atendiendo a los siguientes criterios:

- Presencia o no de células en el injerto implantado.

- Tiempo de cultivo celular en el scaffold.

- Tipo de medio de cultivo para la diferenciación celular.

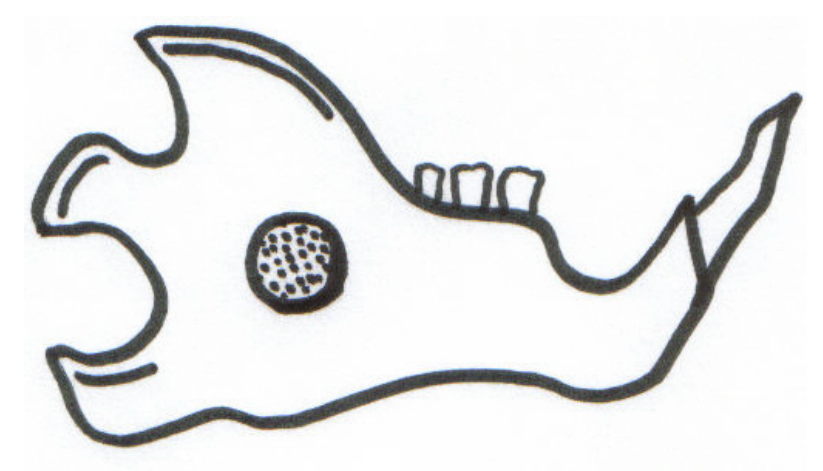

Ilustración 22. Esquema de colocación del injerto en la mandíbula.

De acuerdo a estos criterios, la distribución de los animales se realizó del siguiente modo (ilustración 23):

\section{- Grupo I: HEMIMANDÍBULA DERECHA DE LAS RATAS 1 A 6:}

El defecto óseo se rellenó con Scaffold Meana y células cultivadas durante 24 horas. 


\section{- Grupo II: GRUPO CONTROL: HEMIMANDÍBULA IZQUIERDA DE LAS}

RATAS 1 A 6:

El defecto óseo se rellenó con Scaffold Meana sin ningún tipo de celulas.

\section{- Grupo III: HEMIMANDÍBULA DERECHA DE LAS RATAS 7 A12:}

El defecto óseo se rellenó con Scaffold Meana y células diferenciadas en medio de cultivo durante 21 días.

\section{- Grupo IV: HEMIMANDÍBULA IZQUIERDA DE LAS RATAS 7 A 12:}

El defecto óseo se rellenó con Scaffold Meana y células no diferenciadas cultivadas en medio de expansión durante 21 días.

Vamos a considerar el grupo II como grupo control, ya que es el único en el que sólo utilizamos el scaffold como injerto, en el resto de los grupos utilizamos el scaffold, pero además distintos cultivos celulares sembrados en el interior de dicho scaffold. Por tanto esta distribución de los grupos nos permite realizar una comparativa de los grupos I, III y IV con el grupo control, y además una comparativa de todos los grupos entre sí.

\begin{tabular}{|c|l|l|}
\hline GRUPO & HEMIMANDÍBULA & MATRIZ TRIDIMENSIONAL \\
\hline I & DERECHA & SM* + CÉLULAS 1 DIA CULTIVO \\
\hline II & IZQUIERDA & SM* \\
\hline III & DERECHA & SM* + CÉLULAS DIFERENCIADAS 21 DÍAS \\
\hline IV & IZQUIERDA & $\begin{array}{l}\text { SM* + CÉLULAS NO DIFERENCIADAS } \\
\text { CULTIVADAS 21 DÍAS. }\end{array}$ \\
\hline
\end{tabular}

Ilustración 23. Distribución de los grupos con las matrices a nivel mandibular. SM*: scaffold Meana

Del mismo modo, y complementando dicho estudio, vamos a realizar en cada uno de los animales la implantación del mismo injerto a nivel subcutáneo inguinal (ilustración 
24), de tal manera que establecemos un estudio complementario al principal para evaluar el comportamiento del injerto de forma heterotópica.

\begin{tabular}{|c|c|c|}
\hline GRUPO & FOSA INGUINAL & MATRIZ TRIDIMENSIONAL \\
\hline $\mathrm{I}$ & DERECHA & SM* + CÉLULAS 1 DIA CULTIVO \\
\hline II & IZQUIERDA & $\mathrm{SM}^{*}$ \\
\hline III & DERECHA & SM* + CÉLULAS DIFERENCIADAS 21 DÍAS \\
\hline IV & IZQUIERDA & 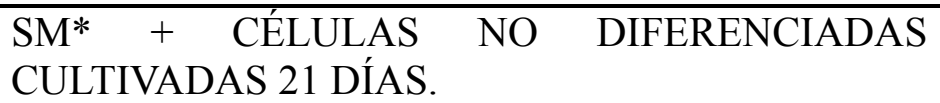 \\
\hline
\end{tabular}

Ilustración 24. Distribución de los grupos con las matrices a nivel inguinal. SM*: scaffold Meana

\subsubsection{DESARROLLO DEL PROTOCOLO QUIRÚRGICO}

Cada animal fue sometido en un único acto operatorio a las dos intervenciones quirúrgicas, tanto el acto de implantación del injerto a nivel de las hemimandíbulas como la implantación inguinal. Todo el proceso operatorio, así como las posteriores manipulaciones de los animales, se llevó a cabo bajo campana de flujo laminar (CS5 Changing Station de Tecniplast), imprescindible para mantener un ambiente lo más estéril posible (ilustración 25). 


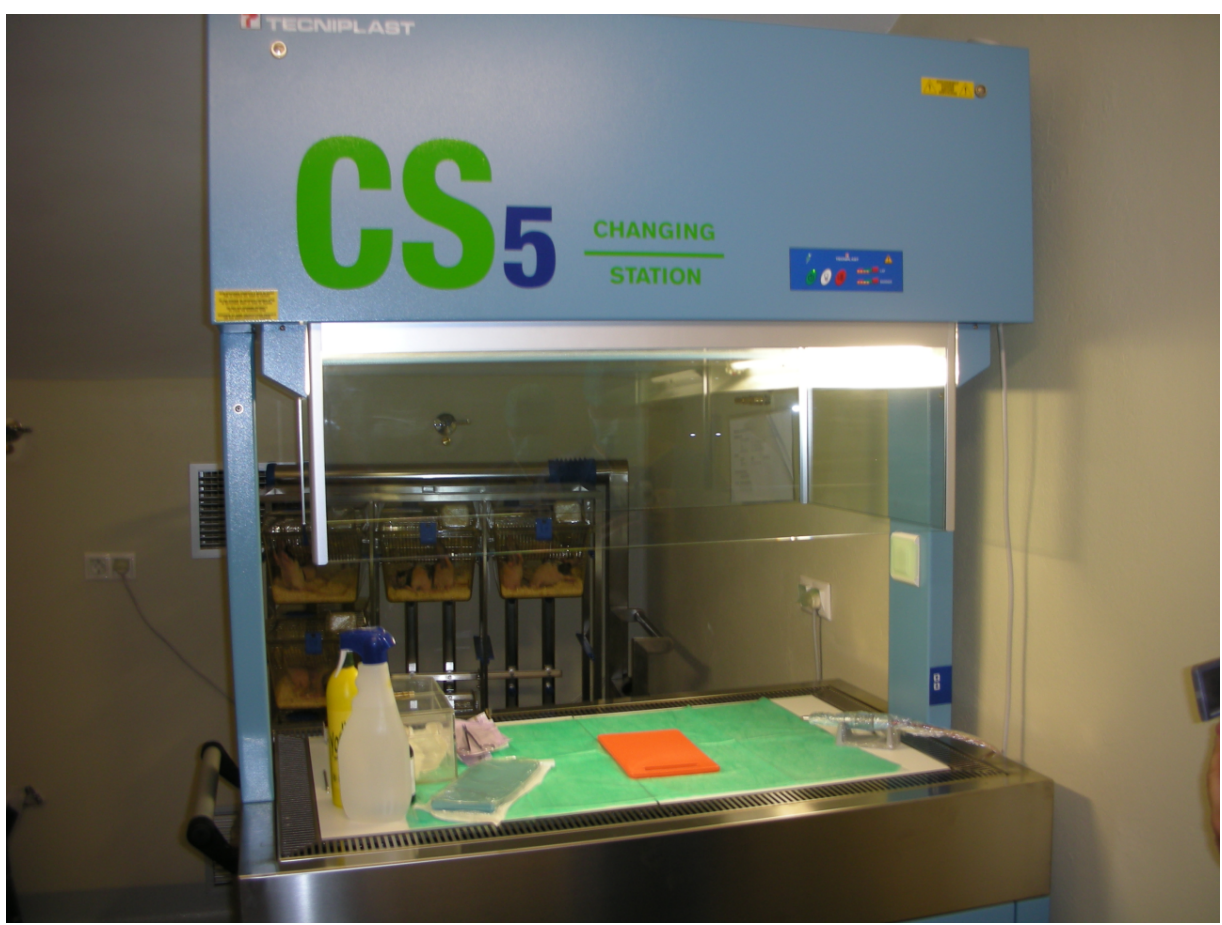

Ilustración 25. Campana de flujo laminar, bajo la cual se llevó a cabo el acto quirúrgico, así como todos los cuidados postoperatorios (Sercicio de Investigación y Bienestar animal de la Facultad de Medicina de la Universidad de Valladolid).

\subsubsection{TÉCNICA ANESTÉSICA}

Se realiza una primera inducción anestésica inhalatoria con éter bajo campana cerrada. Posteriormente se administró una combinación de xilacina $(10 \mathrm{mg} / \mathrm{kg})$ y ketamina $(75$ $\mathrm{mg} / \mathrm{kg}$ ) por vía intraperitoneal, mezclados en la misma jeringa, lográndose un plano anestésico quirúrgico adecuado, repitiéndose con la mitad de dosis a los 30 minutos por la misma vía. Con ello se logra mantener la anestesia durante el tiempo total del procedimiento (60 minutos). Durante este tiempo se mantuvo a los animales sobre una almohadilla térmica para contrarrestar la pérdida de temperatura corporal, dada la importancia que este fenómeno tiene tanto para la supervivencia intraoperatoria, como para la recuperación anestésica y el postoperatorio en general en animales de pequeño tamaño y en particular en los roedores. Esta combinación anestésica no inhibe el reflejo respiratorio, por lo que todos los animales mantuvieron respiración espontánea durante la cirugía. Además realizamos una infiltración local de anestesia con articaína con 
vasoconstrictor $1: 100000,0,5 \mathrm{ml}$ (Ultracain ${ }^{\circledR}$ ) en las zonas operatorias, mediante jeringa tipo carpule.

\subsubsection{TÉCNICA QUIRÚRGICA}

\subsection{ACTO QUIRÚRGICO MANDIBULAR}

Tras la desinfección de las zonas a intervenir con povidona yodada, se realizó sobre cada animal una incisión cutánea submandibular en la línea media, de aproximadamente 1,5 cm de longitud, lo que permitió la exposición del músculo masetero. Se incidió, respetando el nervio facial, sobre dicho músculo hasta identificar el reborde mandibular inferior, el cual fue desperiostizado en toda su longitud. Posteriormente se procedió al despegamiento y exposición de la superficie ósea vestibular y lingual del cuerpo, ángulo y rama ascendente de la mandíbula. El desperiostizado de la superficie vestibular fue amplio, para permitir realizar la ostectomía sin riesgo de lesionar las partes blandas. Una vez realizada esta maniobra, se procedió a identificar el ángulo mandibular, con sus potentes inserciones musculares, el borde posterior de la rama ascendente y la impronta ósea del canino sobre la mandíbula. El despegamiento lingual tuvo que ser muy cuidadoso para no crear una comunicación con la cavidad bucal o lesionar el paquete vásculo-nervioso lingual.

Expuesto el hueso mandibular, y utilizando un retractor del colgajo músculo-cutáneo se procedió a realizar un defecto crítico óseo circular de $4 \mathrm{~mm}$ de diámetro a nivel del cuerpo y rama ascendente mandibular (Kaban y cols, 1979 y 1980; Tiyapatanaputi y col, 2004), existiendo en cualquier caso solución de continuidad en todo el contorno del defecto. Este proceso se llevó a cabo de forma bilateral en ambas hemimandíbulas de cada animal, mediante fresas de carburo de tungsteno de diámetro creciente, utilizando diámetros de fresas redondas de 2 y $4 \mathrm{~mm}$ hasta conseguir el defecto óseo deseado y con alto grado de refrigeración del campo quirúrgico mediante el uso de suero salino 
evitando así cualquier tipo de problema derivado del sobrecalentamiento, como es la necrosis ósea de la zona pudiendo llegar a afectar al posterior proceso de cicatrización. Una vez realizado el defecto crítico posicionamos cada uno de los injertos en el lado correspondiente en función del tipo de grupo al que pertenezcan. El injerto se estabiliza por la propia presión del músculo masetero sobre él mismo, sin colocar ningún tipo de barrera o membrana.

Realizamos sutura por planos; el plano más profundo se suturó con material reabsorbible con Vicryl 5/0, restableciendo así la integridad del músculo masetero. En un segundo plano se procedió al cierre cutáneo de la herida con puntos sueltos de material reabsorbible con Vicryl 4/0 (ilustración 26-33).

\subsection{ACTO QUIRÚRGICO INGUINAL}

Realizada la sutura del campo mandibular, llevamos a cabo dos incisiones oblicuas de 2 cm a nivel de ambos pliegues inguinales en cada uno de los animales y se procede a desecar los tejidos hasta llegar a localizar la arteria epigástrica inferior. Localizada dicha arteria, se genera una bolsillo fasciomuscular retentivo donde depositamos el injerto celular en contacto con el músculo y con el vaso para asegurarnos el aporte vascular al injerto. El cierre de la herida se lleva a cabo en el plano cutáneo con puntos sueltos de material reabsorbible con Vicryl 4/0 (ilustración 34-39). 


\section{MATERIAL Y MÉTODO}

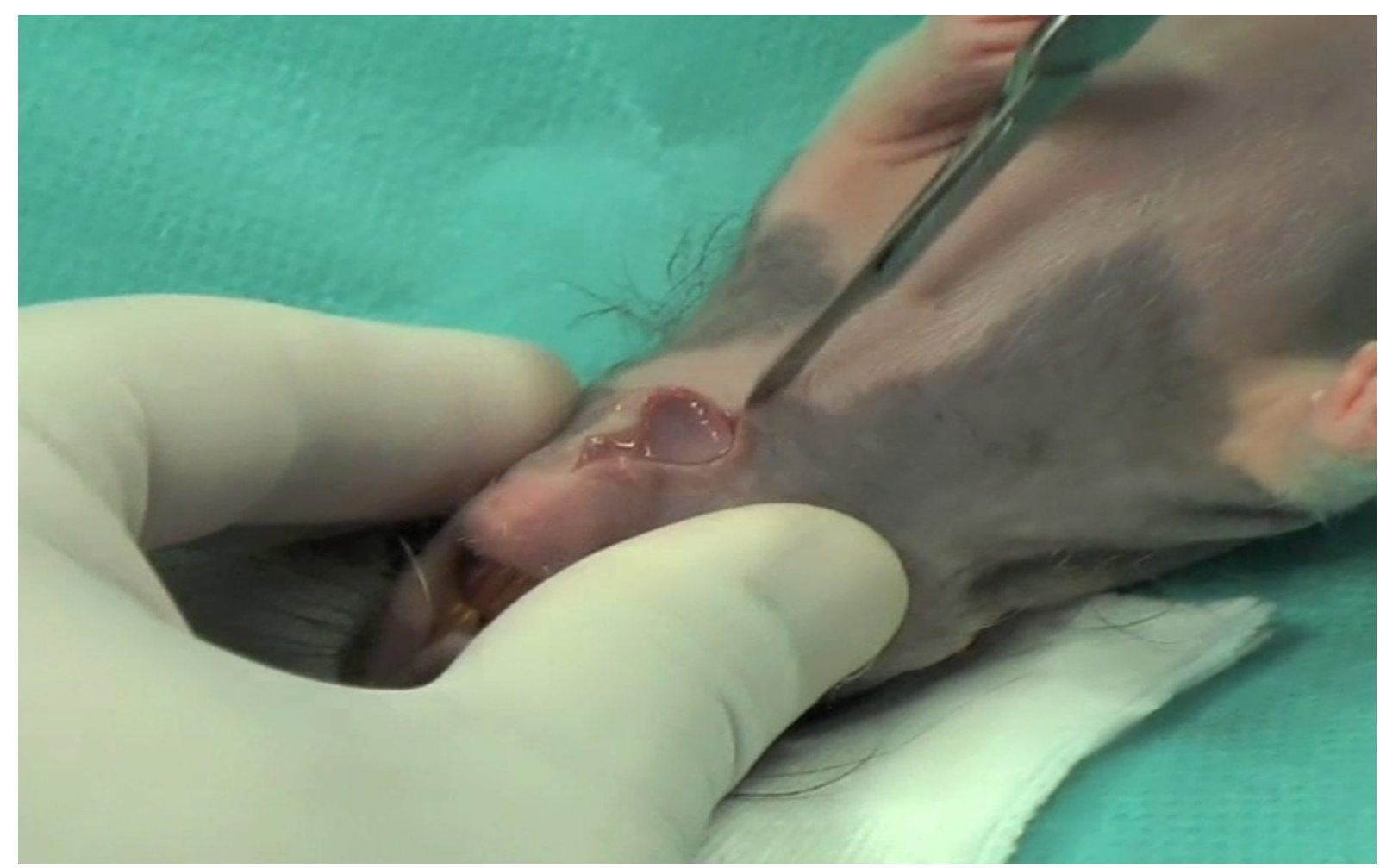

Ilustración 26. Incisión cutánea submandibular en la línea media.

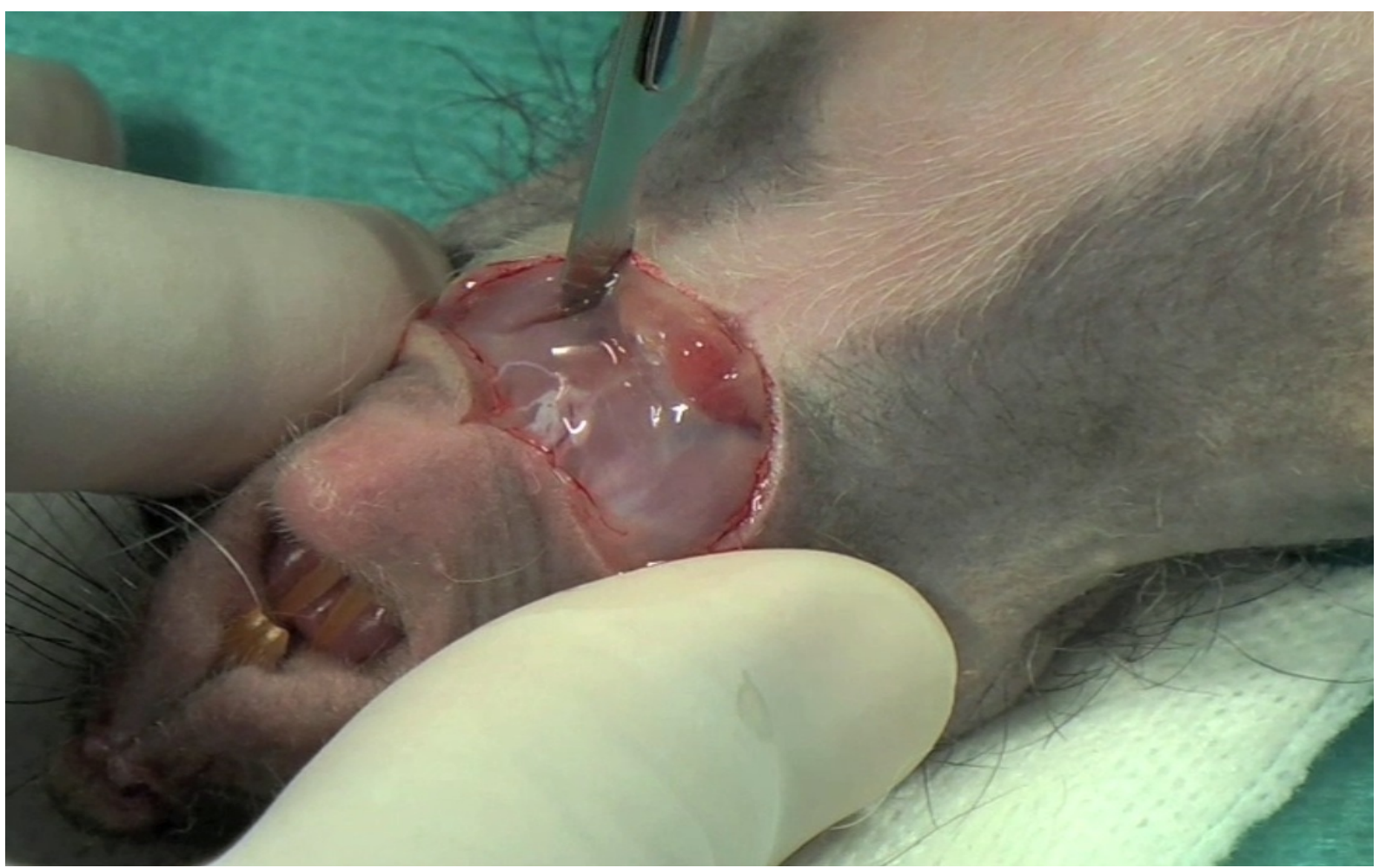

Ilustración 27. Incisión sobre músculo masetero. 


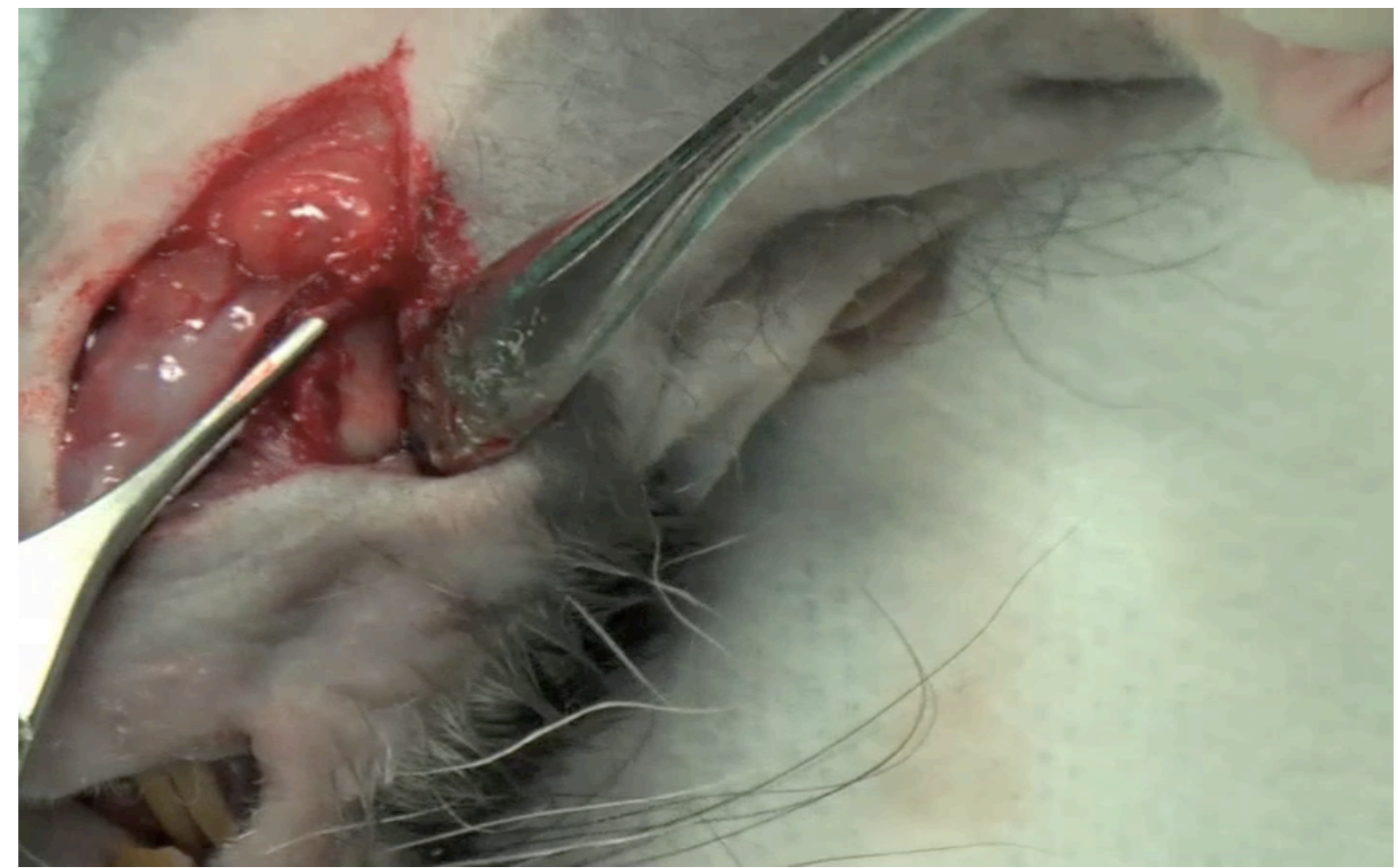

Ilustración 28. Exposición del hueso mandibular.

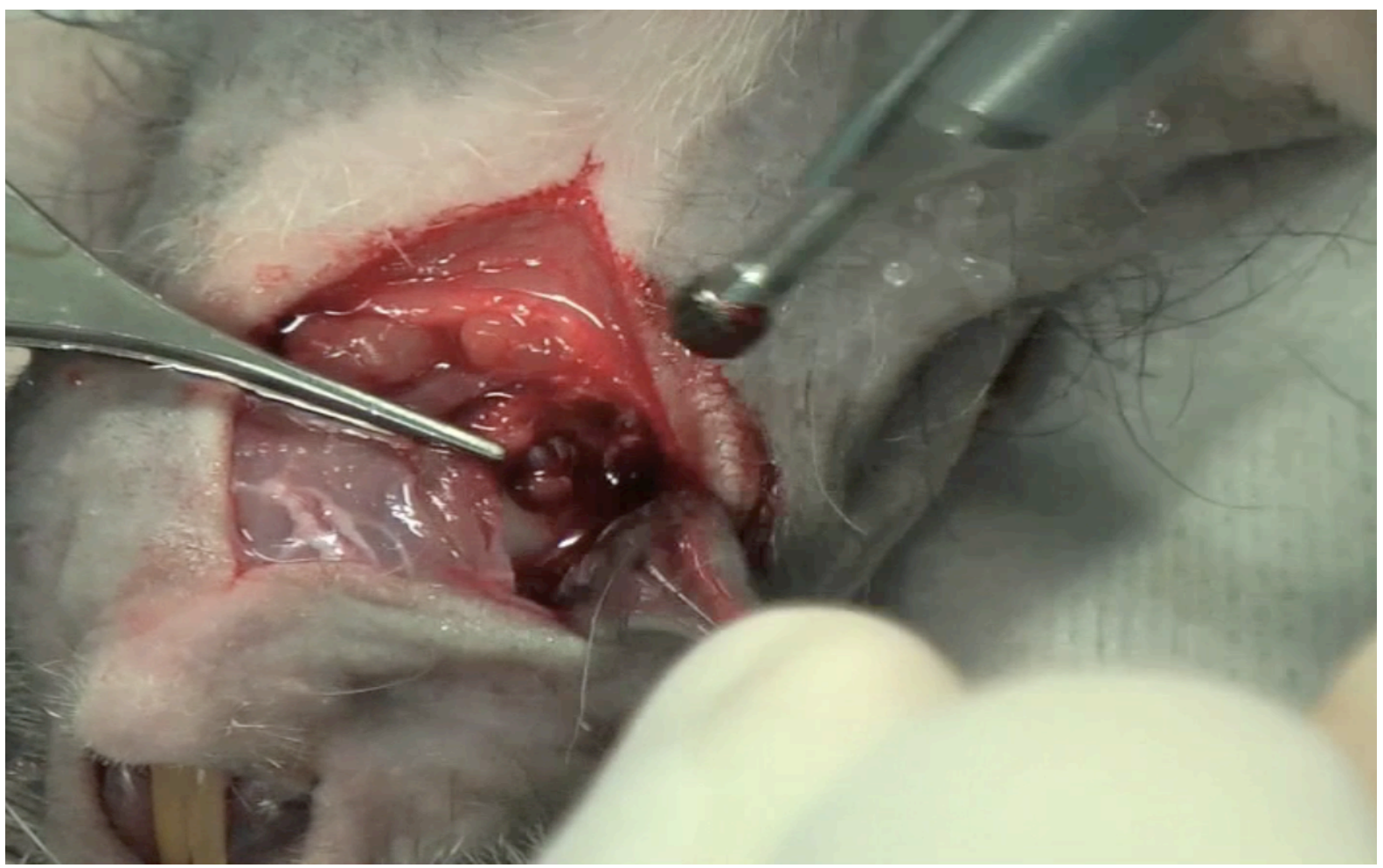

Ilustración 29. Realización de defecto crítico con fresa de $4 \mathrm{~mm}$ a nivel de cuerpo y ramas ascendente mandibular. 


\section{MATERIAL Y MÉTODO}

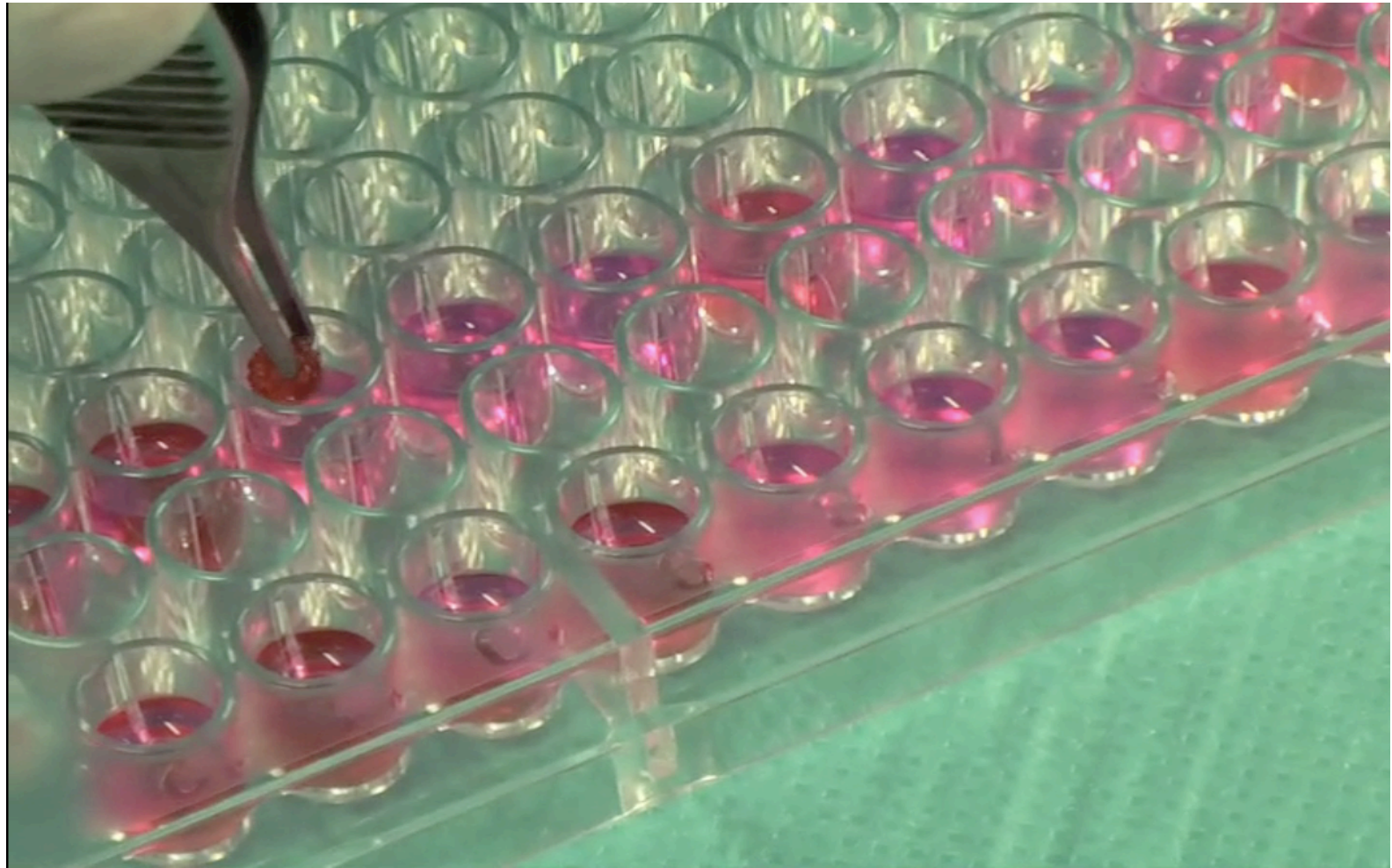

Ilustración 30. Toma del injerto.

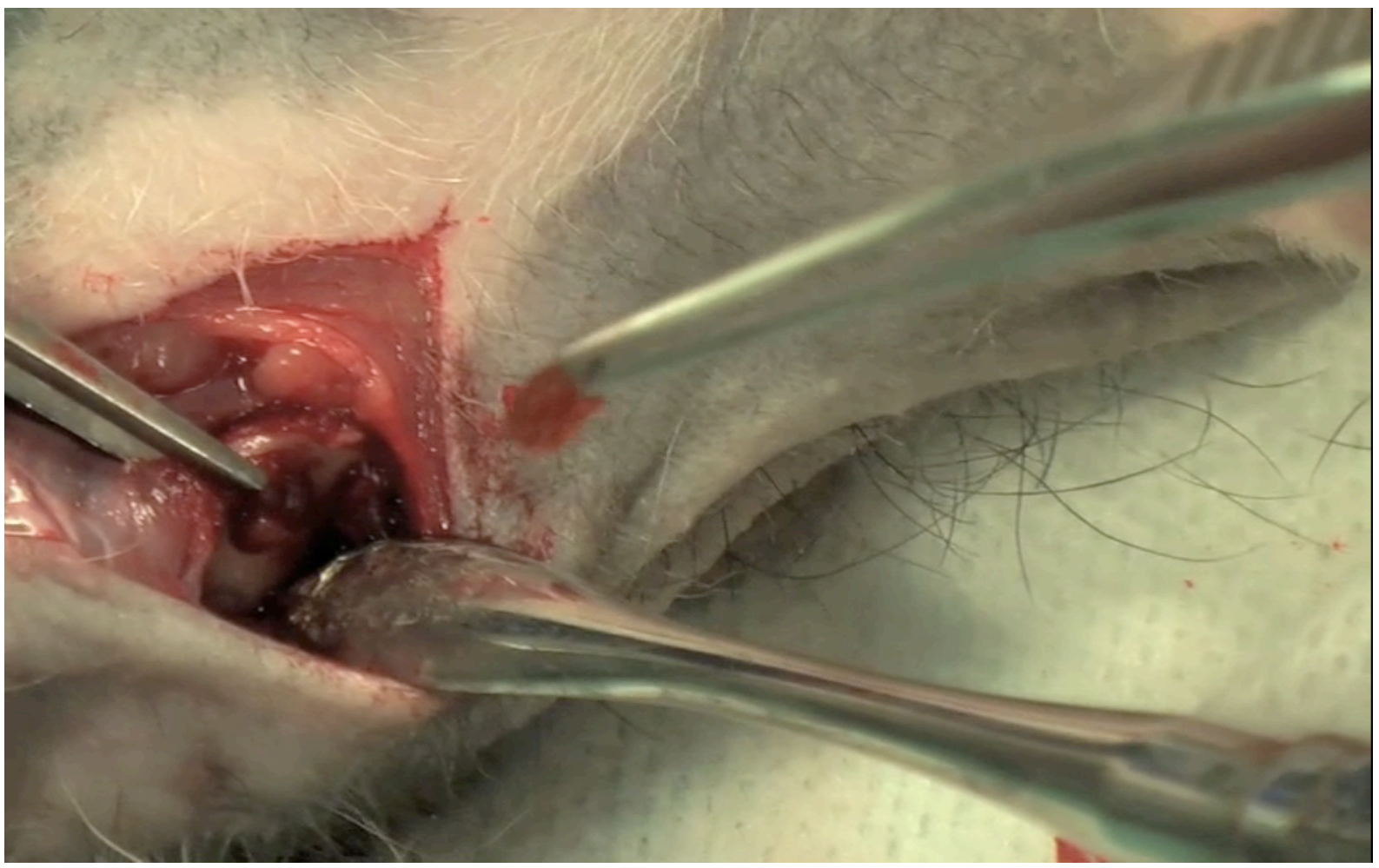

Ilustración 31. Traslado del injerto a la zona del defecto mandibular creado. 


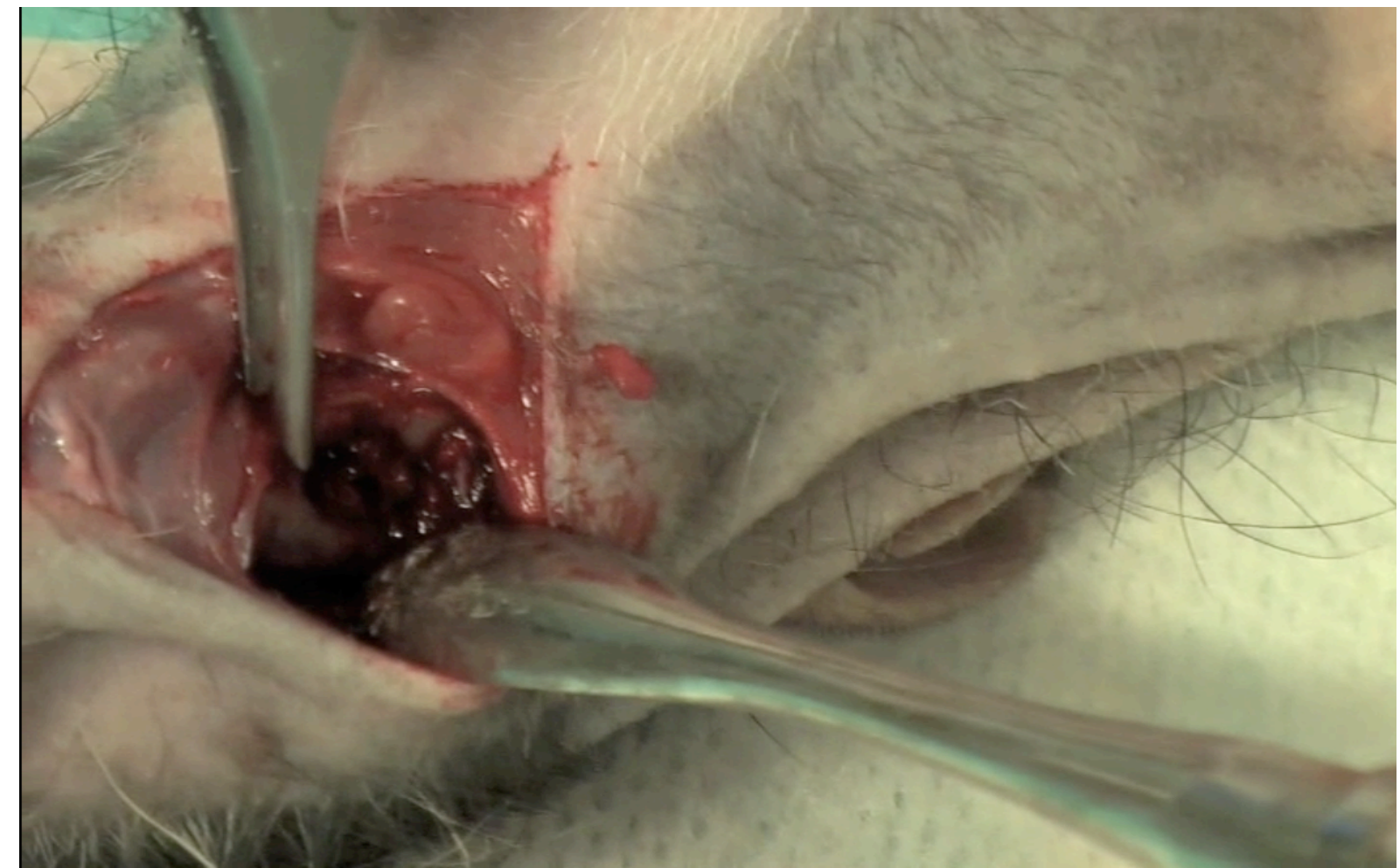

Ilustración 32. Posicionamiento del injerto en el defecto previamente preparado.

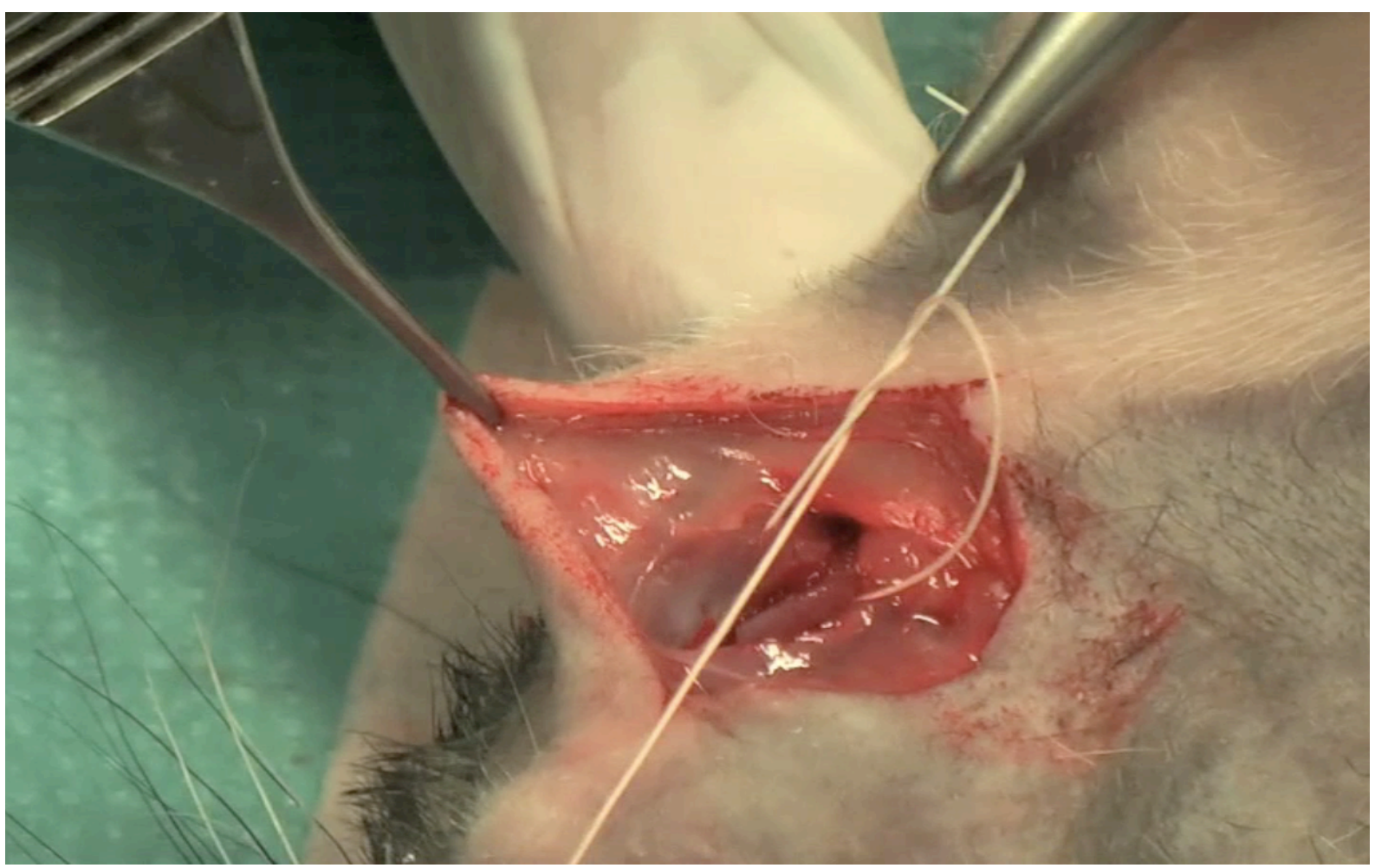

Ilustración 33. Sutura por planos, restableciendo la integridad del músculo masetero. 


\section{MATERIAL Y MÉTODO}

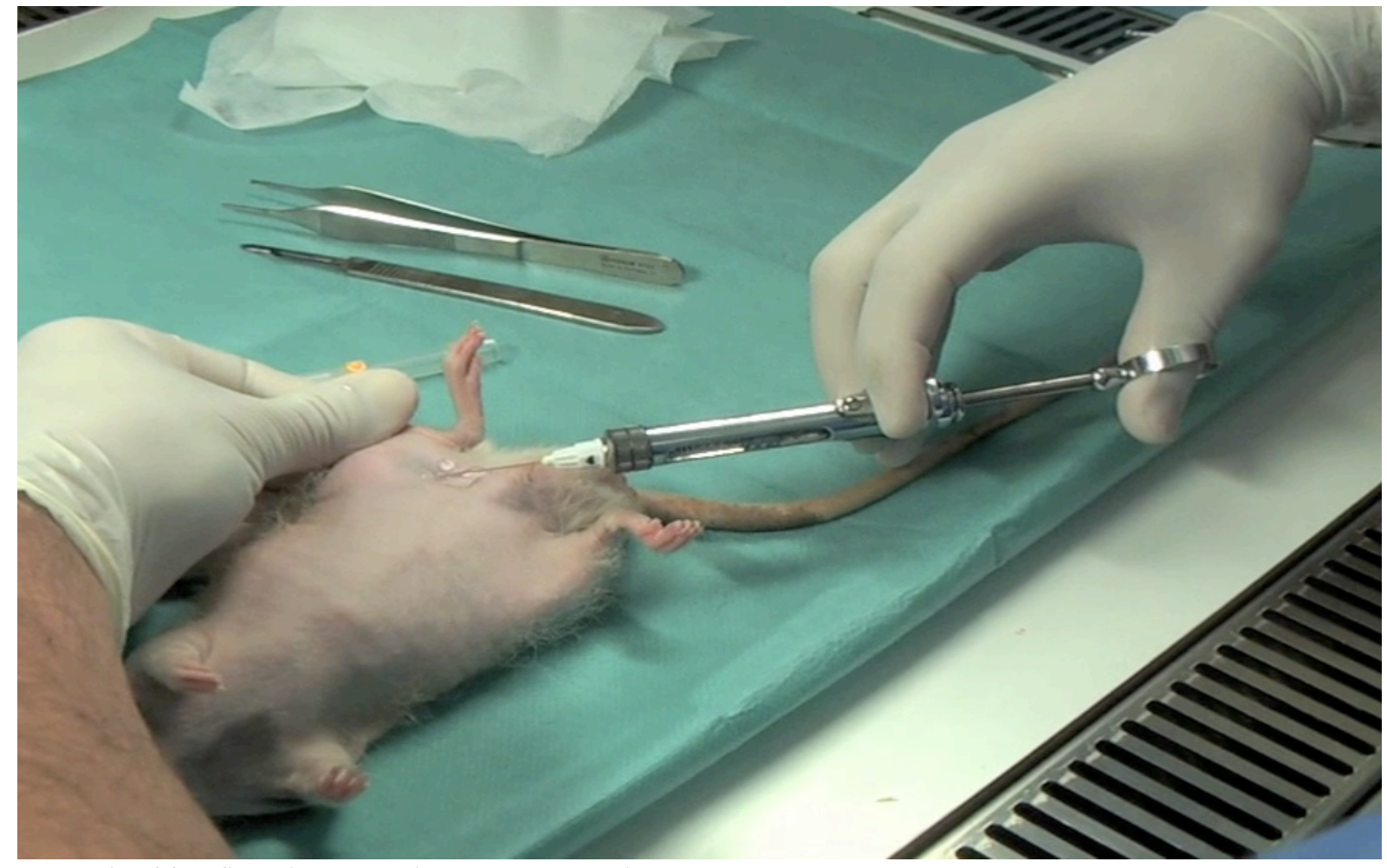

Ilustración 34. Infiltración anestésica con vasoconstrictor.

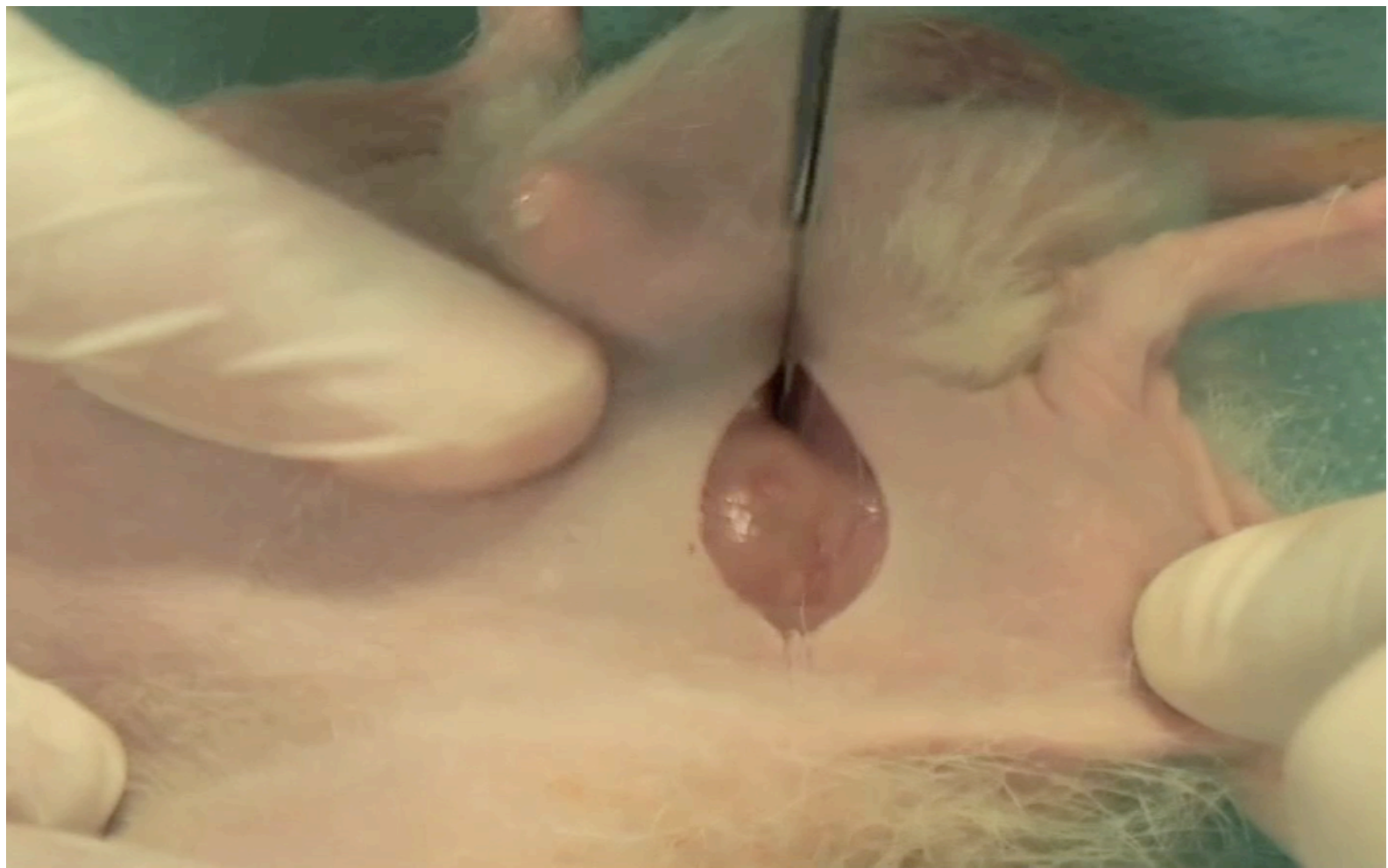

Ilustración 35. Incisión a nivel de la fosa inguinal. 


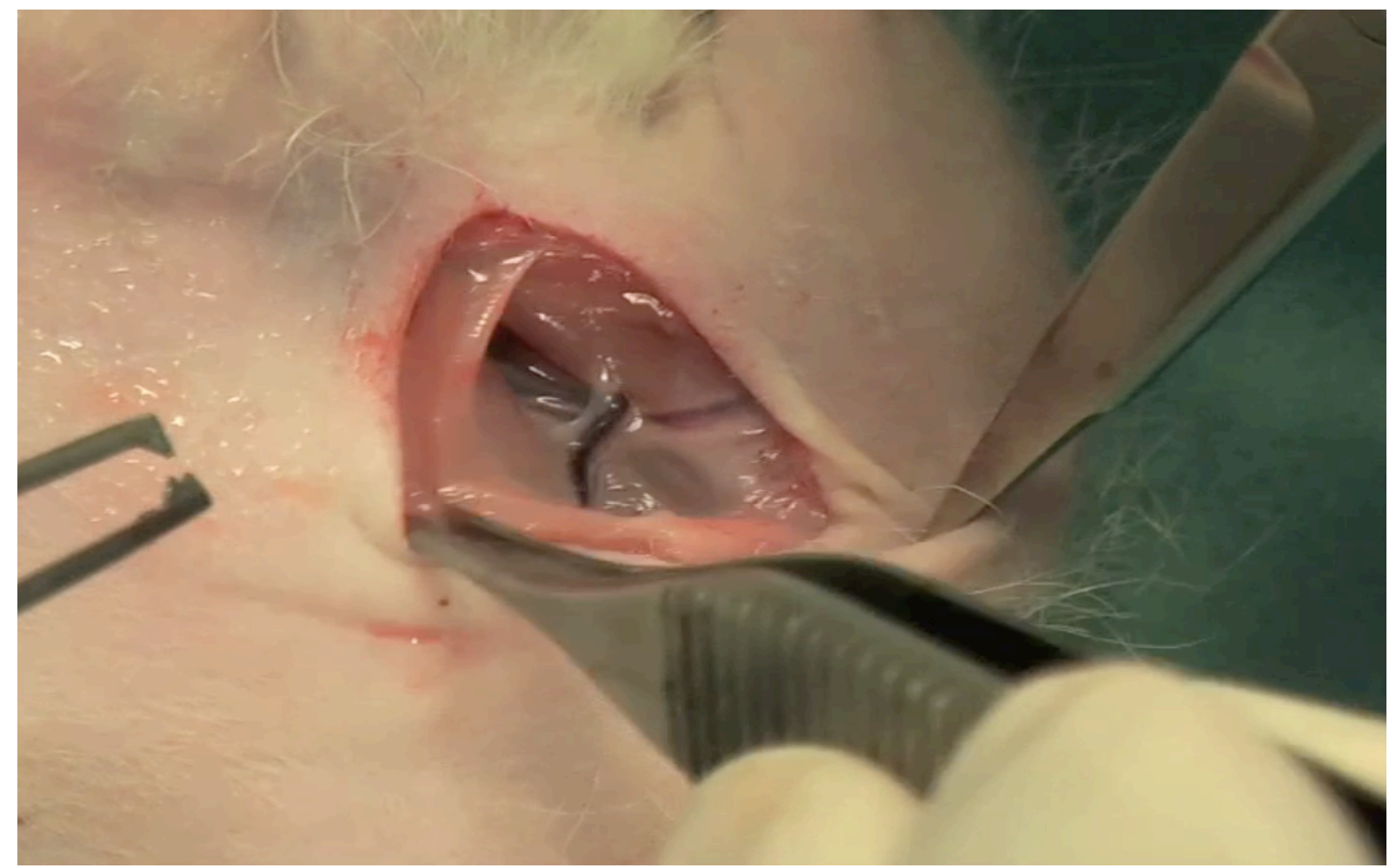

Ilustración 36. Exposición de la arteria epigástrica inferior.

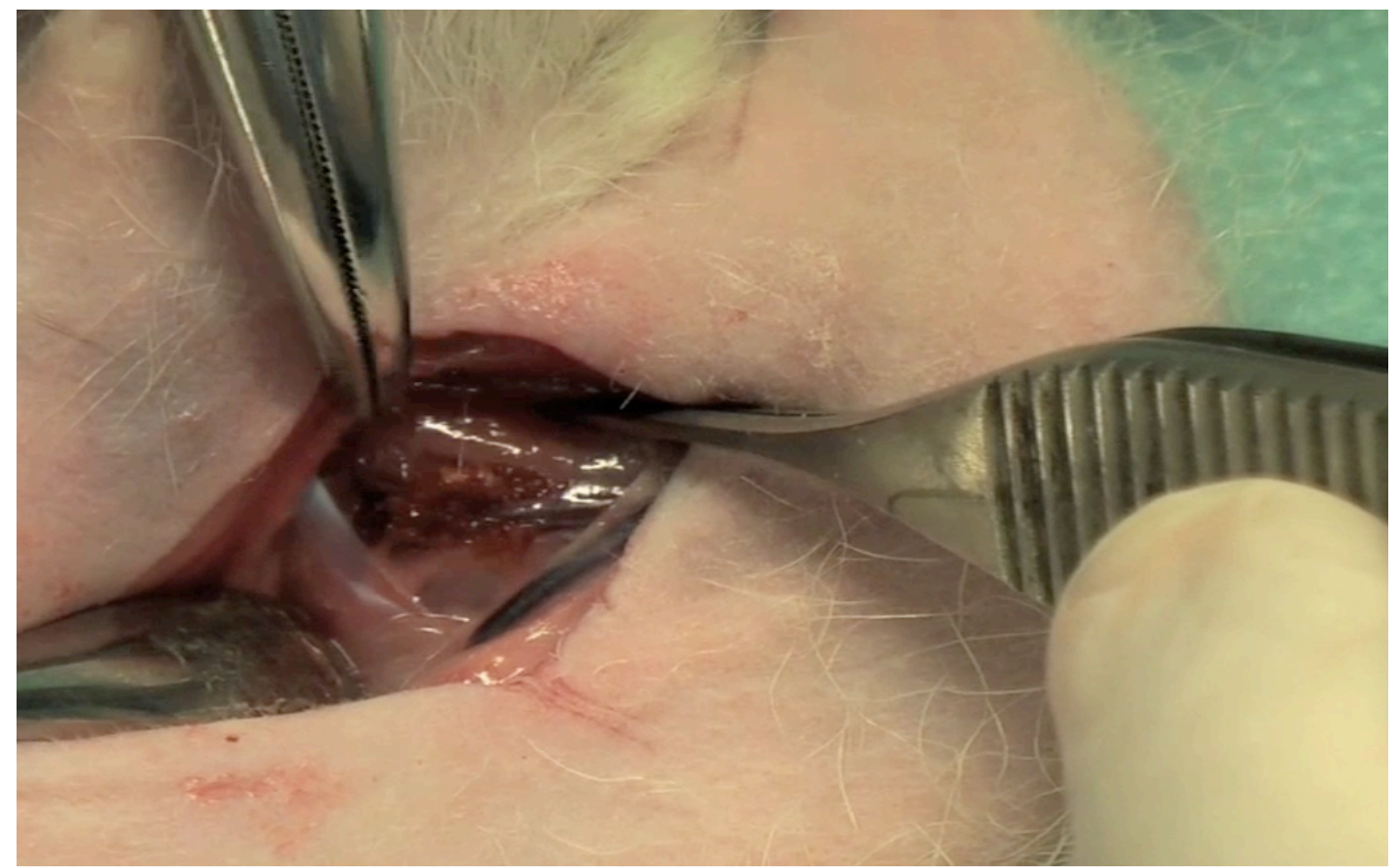

Ilustración 37. Colocación del injerto en contacto con la arteria epigástrica inferior. 


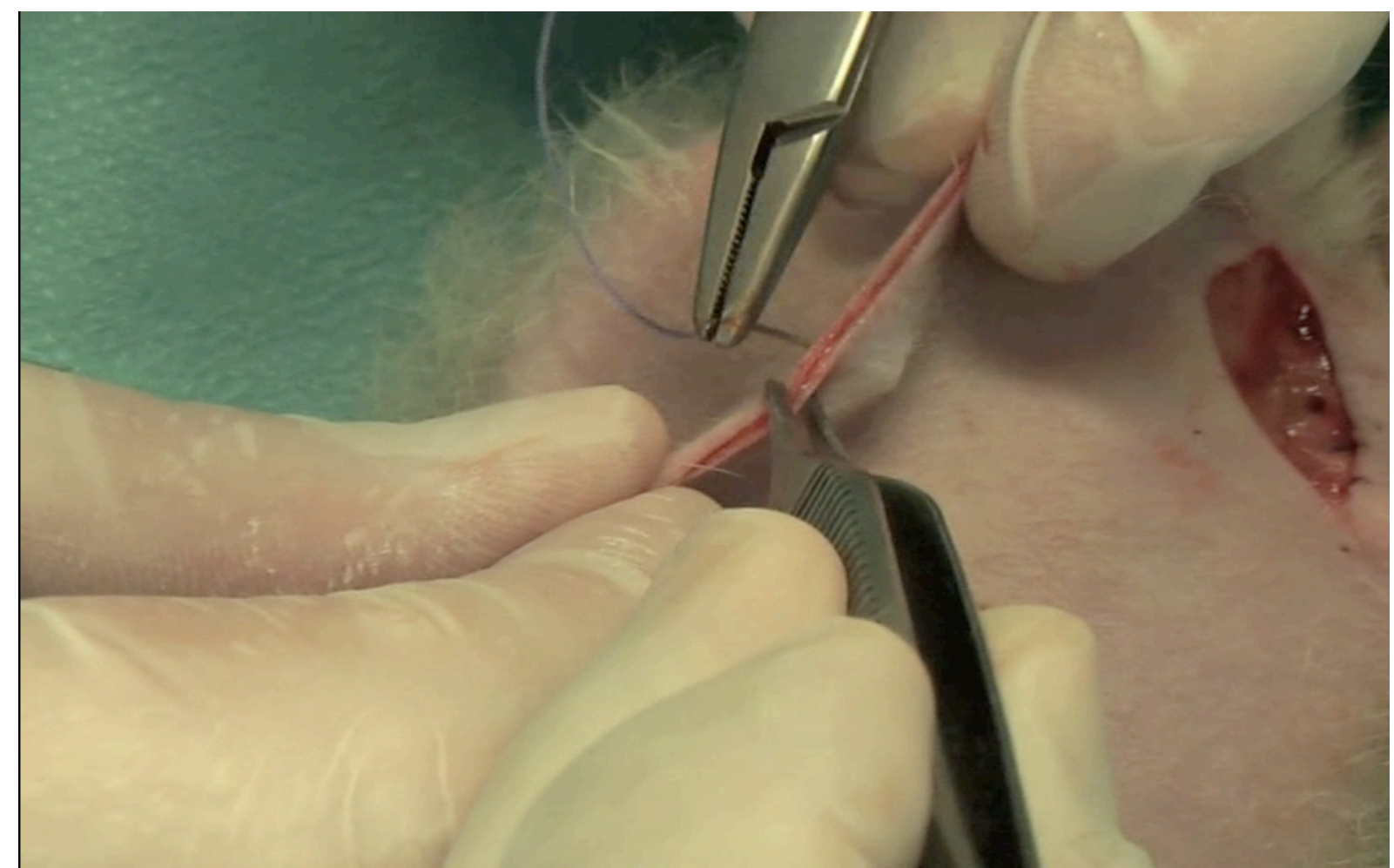

Ilustración 38. Sutura de la herida quirúrgica.

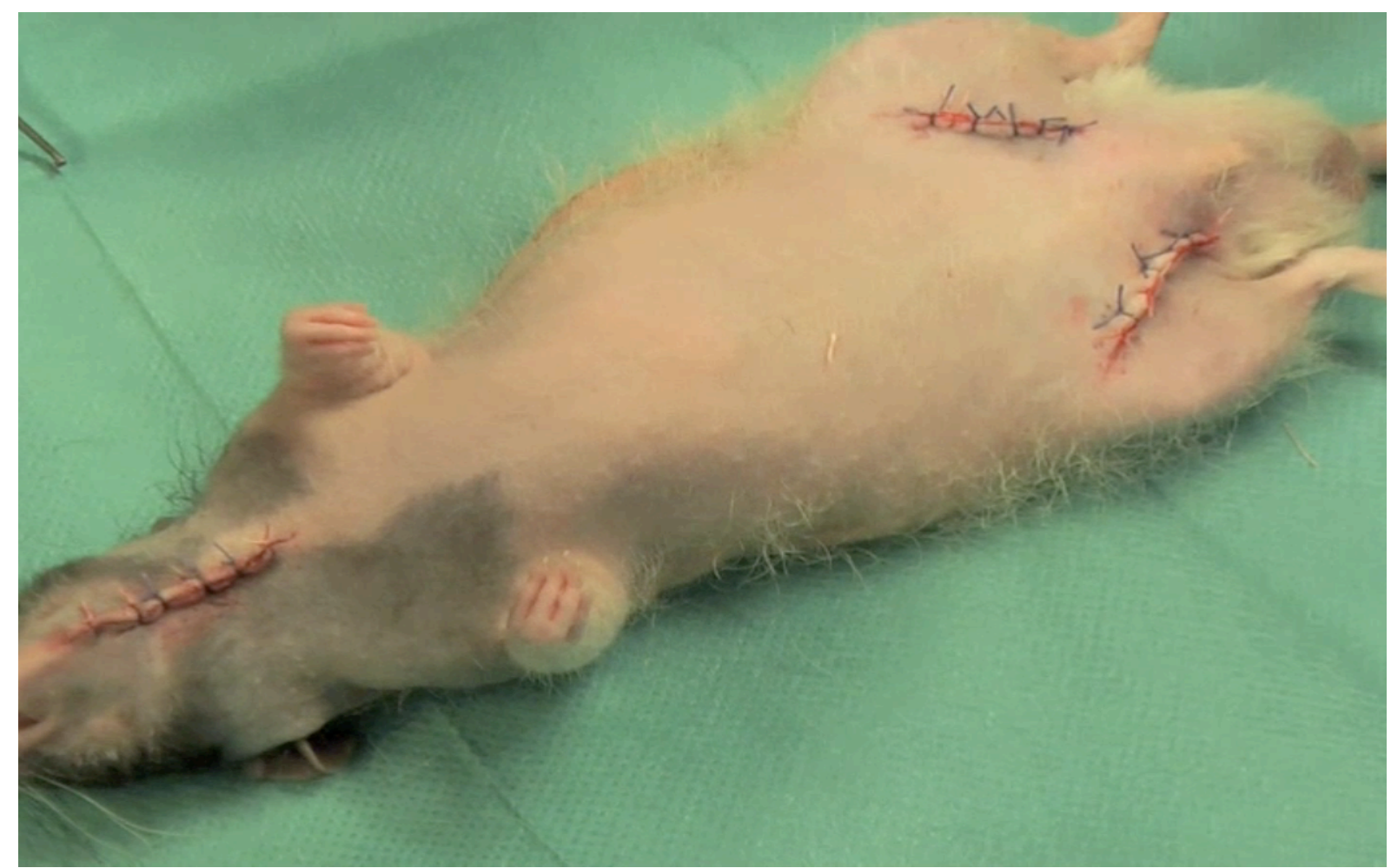

Ilustración 39. Aspecto final del animal después del procedimiento a nivel mandibular e inguinal. 


\subsubsection{SEGUIMIENTO CLÍNICO Y CUIDADOS POSTQUIRÚRGICOS}

Todo el manejo de los animales, tanto el propio de sus cuidados como los procedimientos detallados a lo largo de este trabajo, se realizaron bajo campanas de flujo laminar (CS5 Changing Station de Tecniplast). Se suministró a los animales una dieta estéril para mantenimiento de roedores (2014S Teklad Global 14\% Protein Rodent Maintenance Diet). El agua suministrada a los animales también fue esterilizada por autoclave, con el fin de evitar contaminación microbiológica de ningún tipo, dado el carácter inmunoincompetente de este modelo animal.

Los animales fueron mantenidos en las instalaciones del Animalario del Servicio de Investigación y Bienestar Animal de la Facultad de Medicina de la Universidad de Valladolid con número de registro ES 47180000033, y alojados en Racks ventilados, tres animales por cubeta. La sala en la que se alojan estos animales dispone de presión positiva y filtración HEPA, temperatura controlada de $22^{\circ} \mathrm{C}, 12$ renovaciones de aire por hora y una humedad relativa del 50\% +/- 5\%, así como una regulación controlada y automatizada del ciclo lumínico de 12 horas de luz y 12 de oscuridad.

A todos los animales se les administró una solución de antibióticos durante la primera semana y fueron examinados periódicamente, valorando los siguientes parámetros:

- Estado general del animal.

- Aspecto de la herida y de la zona intervenida.

- Sangrado, exudado o colecciones.

- Extrusión del injerto.

- Cambios degenerativos por lesión dentaria.

De los doce animales intervenidos, uno de ellos (animal nº 8 ) no formó parte del estudio por muerte intraoperatoria. 


\subsection{SACRIFICO DE LOS ANIMALES Y OBTENCIÓN DE LAS MUESTRAS}

El sacrificio de los animales se realizó mediante aspiración de monóxido de carbono en cámara de eutanasia, método aprobado como aceptable con el animal consciente por diferentes asociaciones relacionadas con el bienestar de los animales de laboratorio a nivel internacional, así como por el Comité de Ética del Centro. Todos los animales fueron sacrificados al cabo de 12 semanas de la implantación del injerto. (Close y cols, 1996; Close y cols, 1997; Association A.V.M, 2007).

Se sacrificaron 11 de los 12 animales intervenidos. Por tanto se pudo realizar el estudio de los especímenes $\mathrm{n}^{\mathrm{o}} 1,2,3,4,5,6,7,9,10,11$ y 12 .

La obtención de las muestras se realizó mediante extirpación en bloque de cada una de las hemimandíbulas de cada animal, liberando las partes blandas adheridas. Del mismo modo y en el mismo acto se realizaron abordajes en las zonas inguinales para recuperar los injertos a ese nivel (ilustración 40-45).

Las hemimandíbulas fueron sumergidas inmediatamente a la extracción en etanol al $70 \%$ en recipientes debidamente identificados, para poder llevar a cabo el posterior análisis radiológico en las 4 horas siguientes.

Los injertos recuperados de las zonas inguinales, fueron sumergidos en formol al $10 \%$ tamponado para su conservación hasta su posterior estudio.

De este modo se obtuvieron las siguientes muestras que se sometieron a estudio radiológico (muestras mandibulres) como al posterior estudio histológico (muestras mandibulares e inguinales):

GRUPO I: 6 muestras mandibulares y 6 inguinales.

GRUPO II: 6 muestras mandibulares y 6 inguinales.

GRUPO III: 5 muestras mandibulares y 5 inguinales.

GRUPO IV: 5 muestras mandibulares y 5 inguinales. 


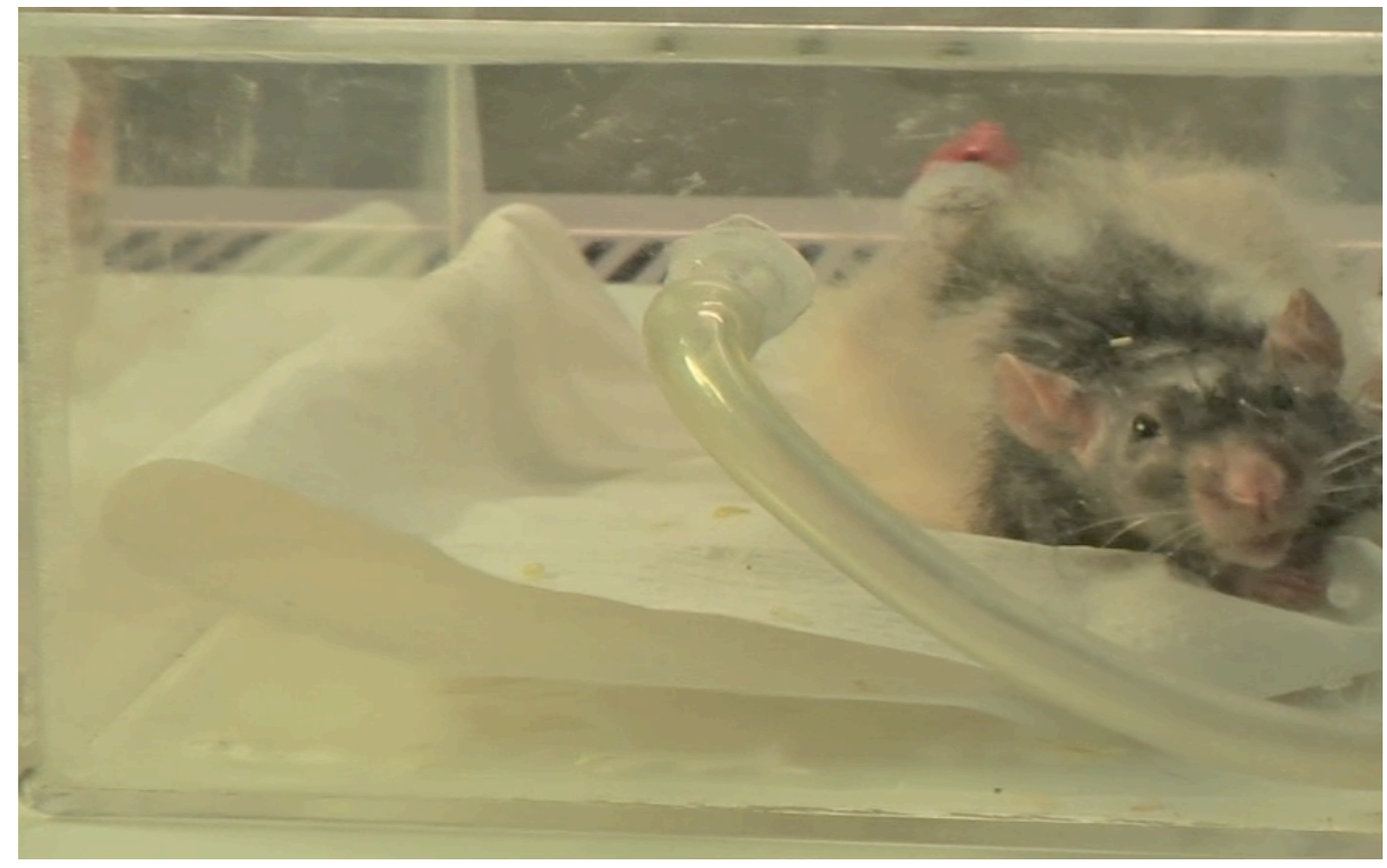

Ilustración 40. Sacrificio del animal: en cámara de eutanasia, mediante aspiración de monóxido de Carbono.

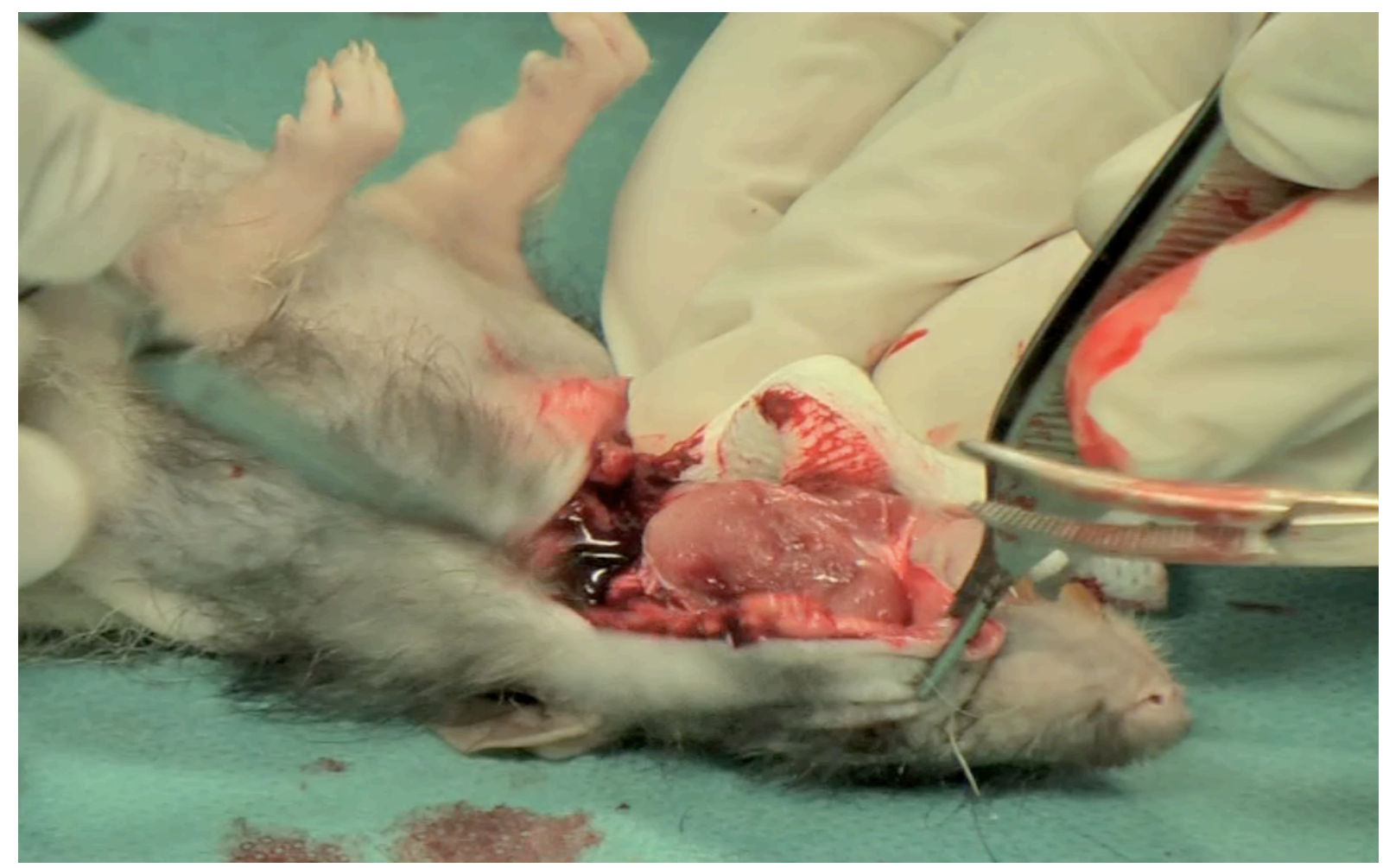

Ilustración 41. Extracción en bloque de la mandíbula del animal. 


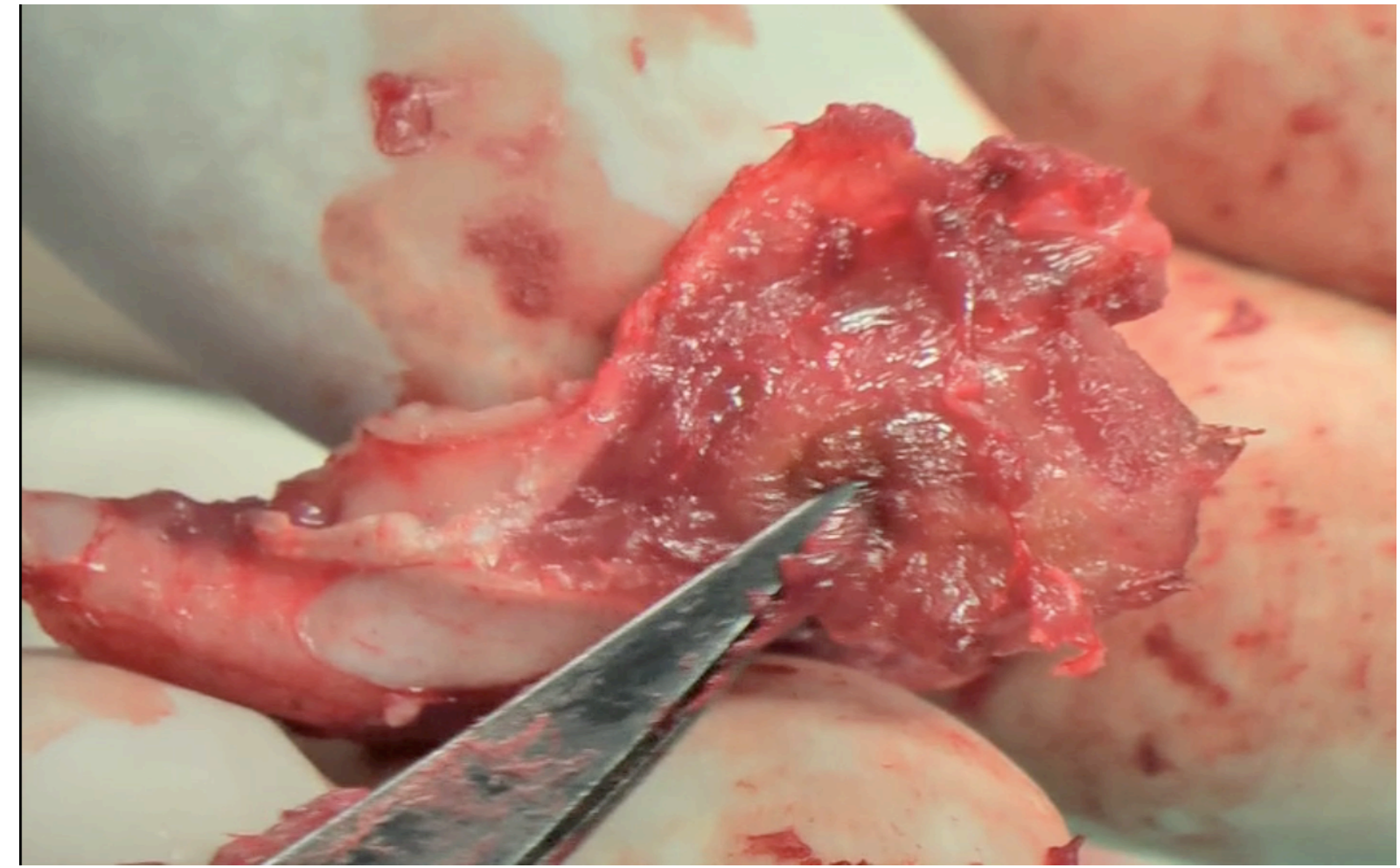

Ilustración 42. Aspecto de la mandíbula inmediato a la extracción, en la que se observa la zona del defecto. Cara externa mandibular.

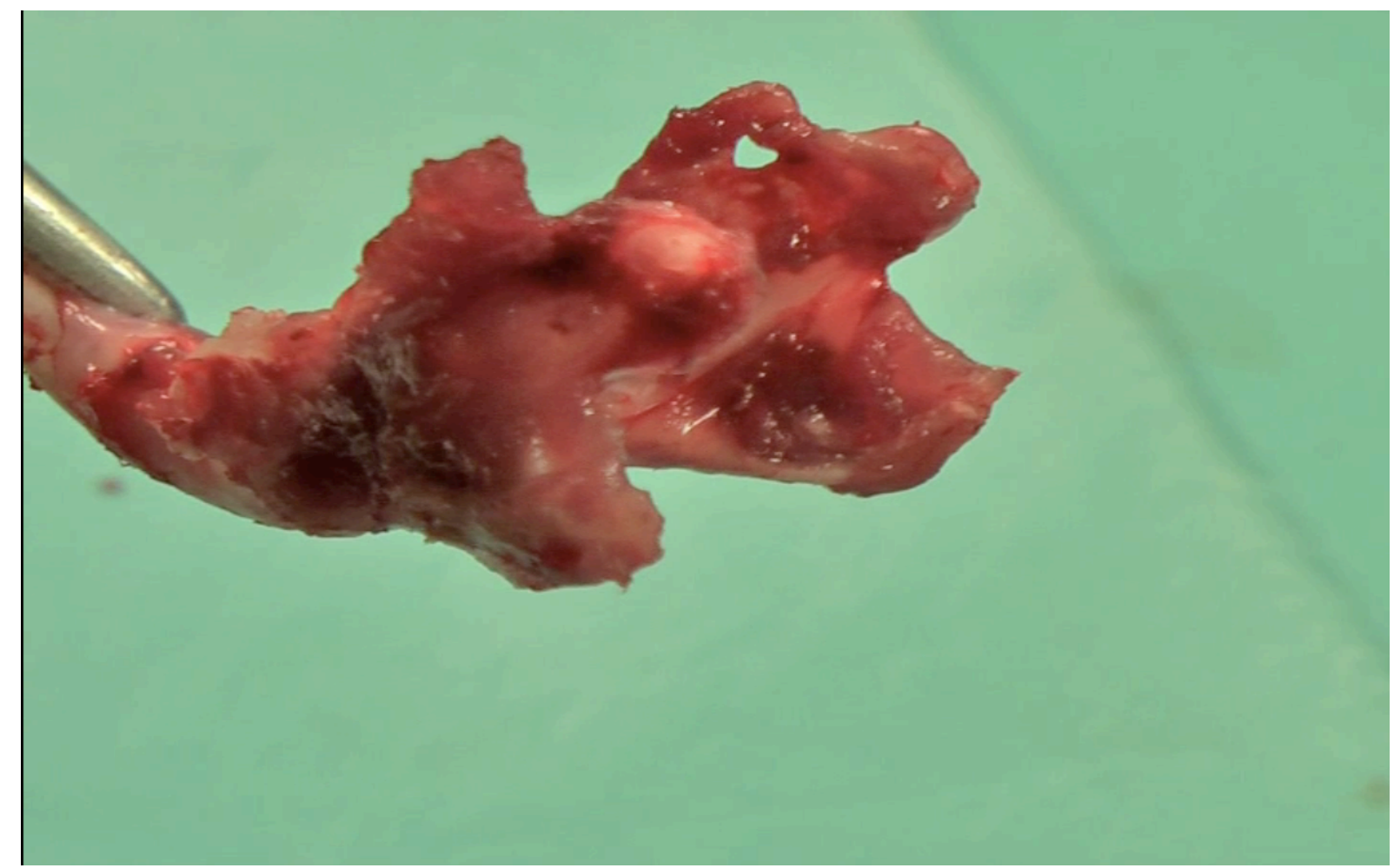

Ilustración 43. Aspecto de la mandíbula inmediato a la extracción, en la que se observa la zona del defecto. Cara medial mandibular. 


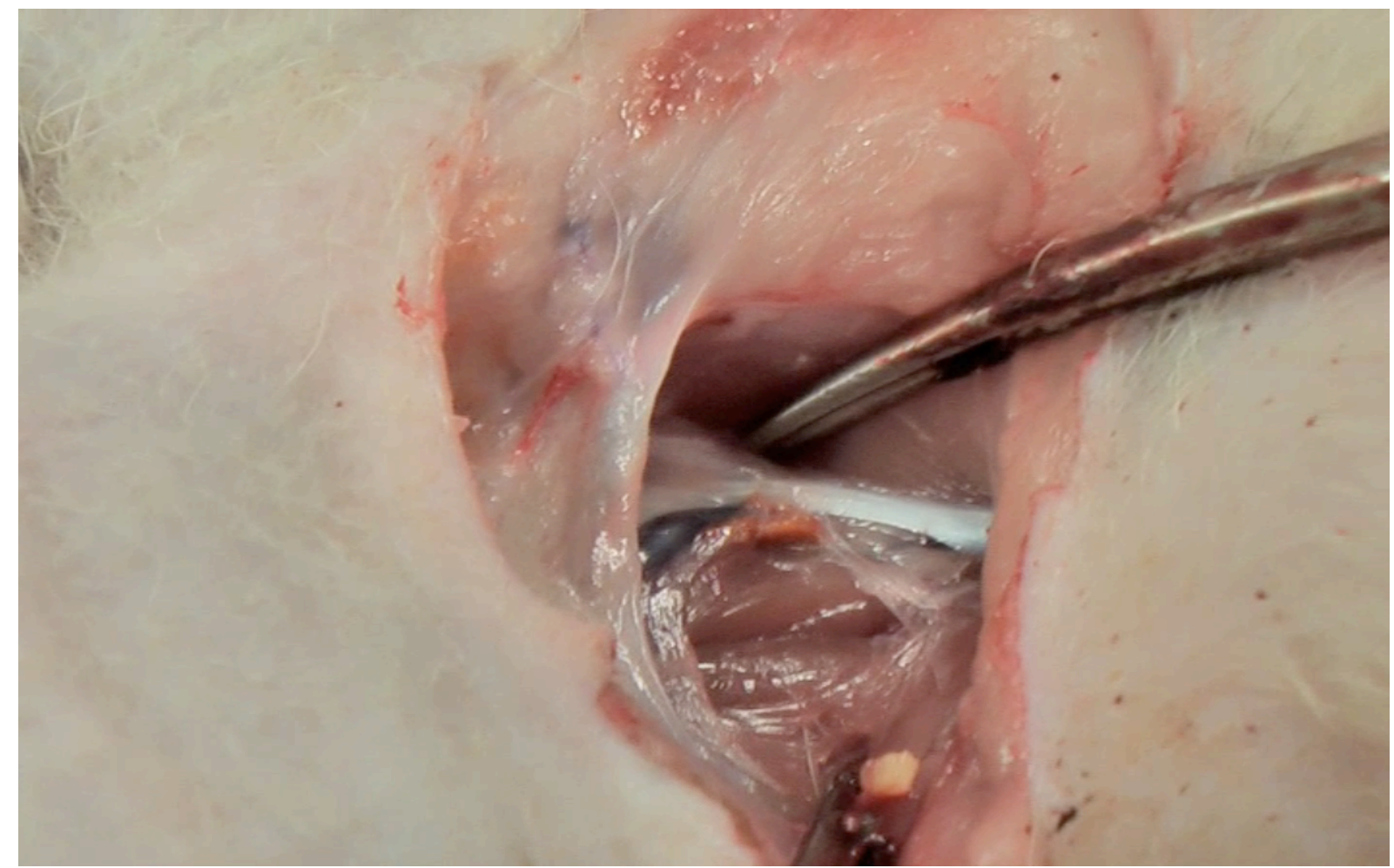

Ilustración 44. Abordaje a zona inguinal y disección de tejidos hasta hacer visible la arteria epigástrica inferior.

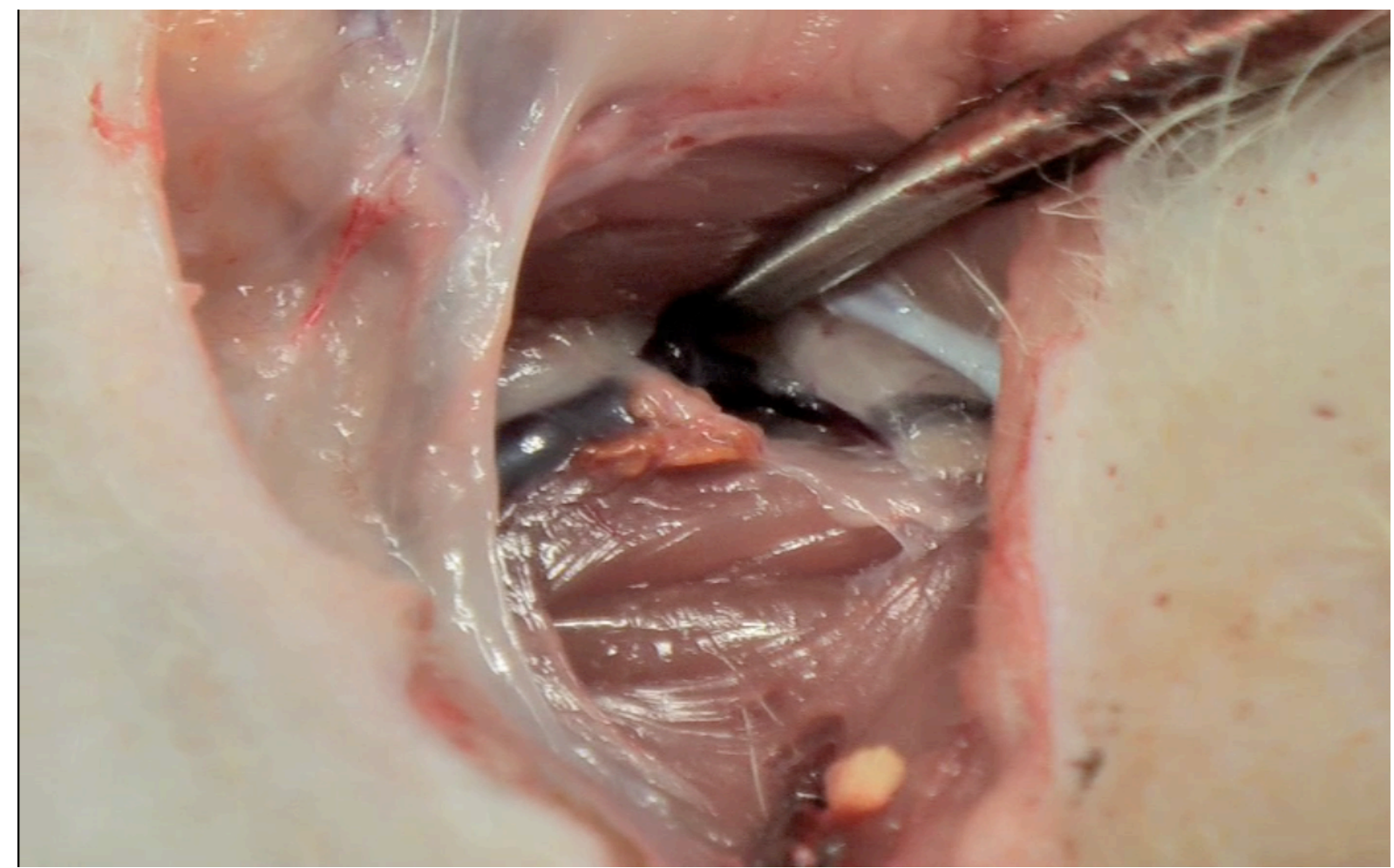

Ilustración 45. Abordaje directo al injerto, con un consistencia más dura, y adherido a la arteria epigástrica inferior de donde ha obtenido vascularización. 


\subsection{PROCESADO RADIOLÓGICO DE LAS MANDÍBULAS: ESTUDIO EN TAC MULTICORTE}

Todas las muestras fueron analizadas mediante Tomografía Computerizada multicorte, utilizando un aparato tipo Siemens Somatom Sensation ${ }^{\circledR}$.

Las muestras se alojaron en cilindro trasparente de metacrilato totalmente sellado, colocándolo sobre el soporte del TAC posicionando el eje mayor de las ramas mandibulares en el plano axial, realizándose en un primer momento el "scout view" en proyecciones anteroposteriores y lateral, para poder programar el estudio tomográfico ajustándolo al campo de visión del tamaño de la muestra.

Para cada adquisición volumétrica de cada una de las muestras se empleo una técnica de $120 \mathrm{KV}$ con un grosor de corte de 0,2 $\mathrm{mm}$ de espesor, usando las dosis apropiadas para la densidad de las muestras. La reconstrucción de las imágenes se hizo con matriz de 1024x1024 con los algoritmos apropiados para el estudio óseo, obteniendo así imágenes en formato DICOM.

La valoración radiológica del defecto se llevó a cabo desde un punto de vista tanto cualitativo como cuantitativo.

\subsubsection{VALORACIÓN RADIOLÓGICA CUALITATIVA}

Se describió de forma subjetiva la reparación radiológica del defecto mandibular, estudiando los siguientes parámetros:

1. Homogeneidad de la reparación radiológica del defecto.

2. Continuidad radiológica del injerto en el defecto. 


\subsubsection{VALORACIÓN RADIOLÓGICA CUANTITATIVA}

En las 4 horas posteriores al sacrificio de los animales, se realizó un estudio de tomografía computarizada, a las mandíbulas extraídas, en el servicio de Radiología del Hospital Universitario Río Hortega de Valladolid, introduciendo todas las mandíbulas seguidas en un cilindro trasparente de metacrilato perfectamente sellado. Las imágenes obtenidas fueron evaluadas mediante el programa de análisis de imágenes Osiri $X{ }^{\circledR}$ versión 3.5.1 para Macintosh ${ }^{\circledR}$. Se obtiene en primer lugar una imagen tridimensional de cada una de las mandíbulas (ilustración 46 y 47).

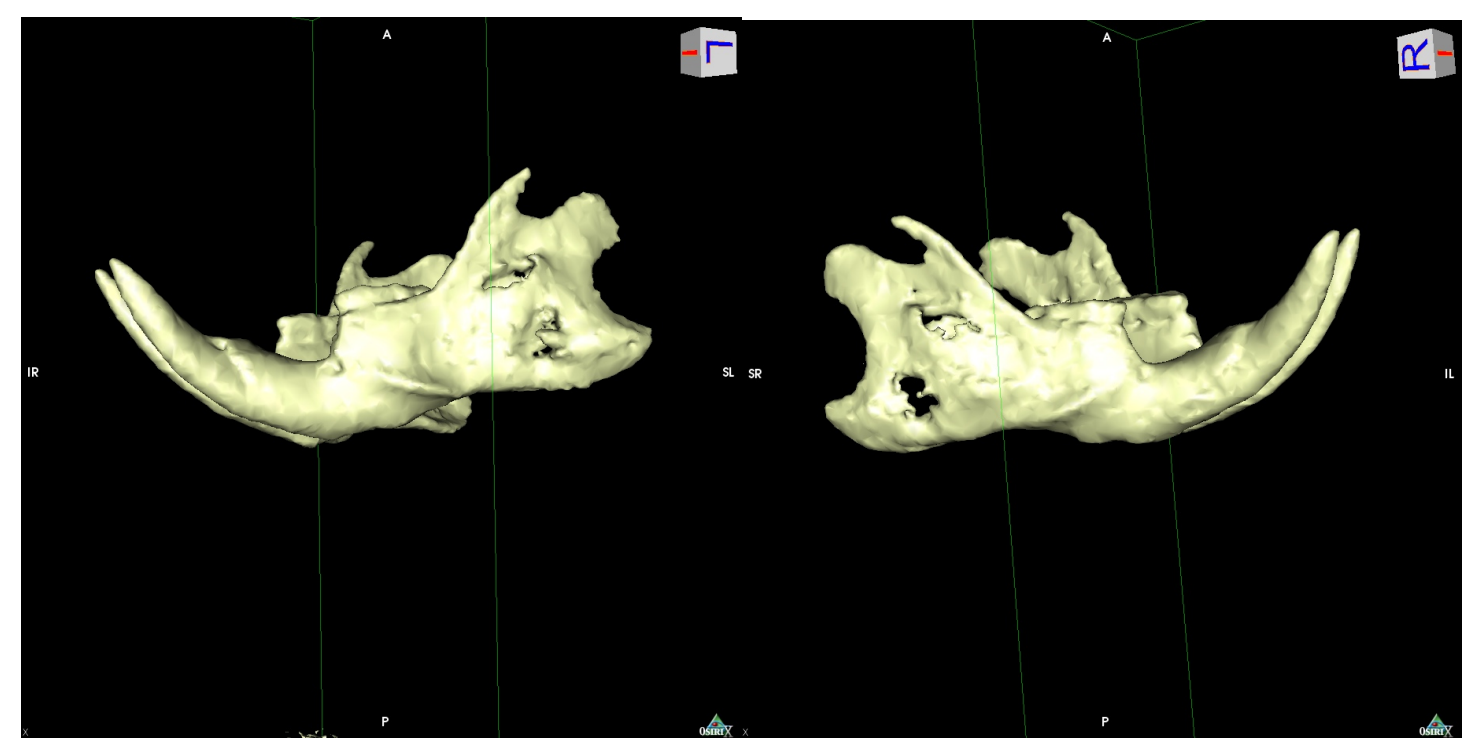

Ilustración 46 (izquierda) e ilustración 47 (derecha). Imagen tridimensional de mandíbula de rata obtenida tras el tratamiento con el programa OsiriX (3D RECONSTRUCCIÓN VOLUMÉTRICA).

La vista 2D MPR ORTOGONAL (ilustración 49), que nos facilita el programa, nos permitirá estudiar imágenes en los planos sagital, coronal y axial. Es en estas imágenes donde vamos a llevar a cabo el estudio cuantitativo, para lo cual utilizaremos una herramienta del programa denominada CLUT (Color Look-Up Tables) (ilustración 50), que permite transformar la escala de grises en una escala de colores. Obtenemos por tanto imágenes en una escala colorimétrica en los 3 planos del espacio más sencillas e intuitivas para el estudio de las distintas densidades radiológicas. 
Definimos exactamente cuál es el área a estudiar en cada una de los cortes que obtendremos, para lo cual dimensionamos el defecto creado en cada hemimandíbula (ilustración 48): consideramos un grosor medio de la mandíbula de cada animal en la zona donde realizamos el defecto de $0.8 \mathrm{~mm}$ y un diámetro de $4 \mathrm{~mm}$ (diámetro de la fresa utilizada en la ostectomía); por tanto obtenemos un cilindro con una base de 0,4 cm y altura de $0,08 \mathrm{~cm}$.

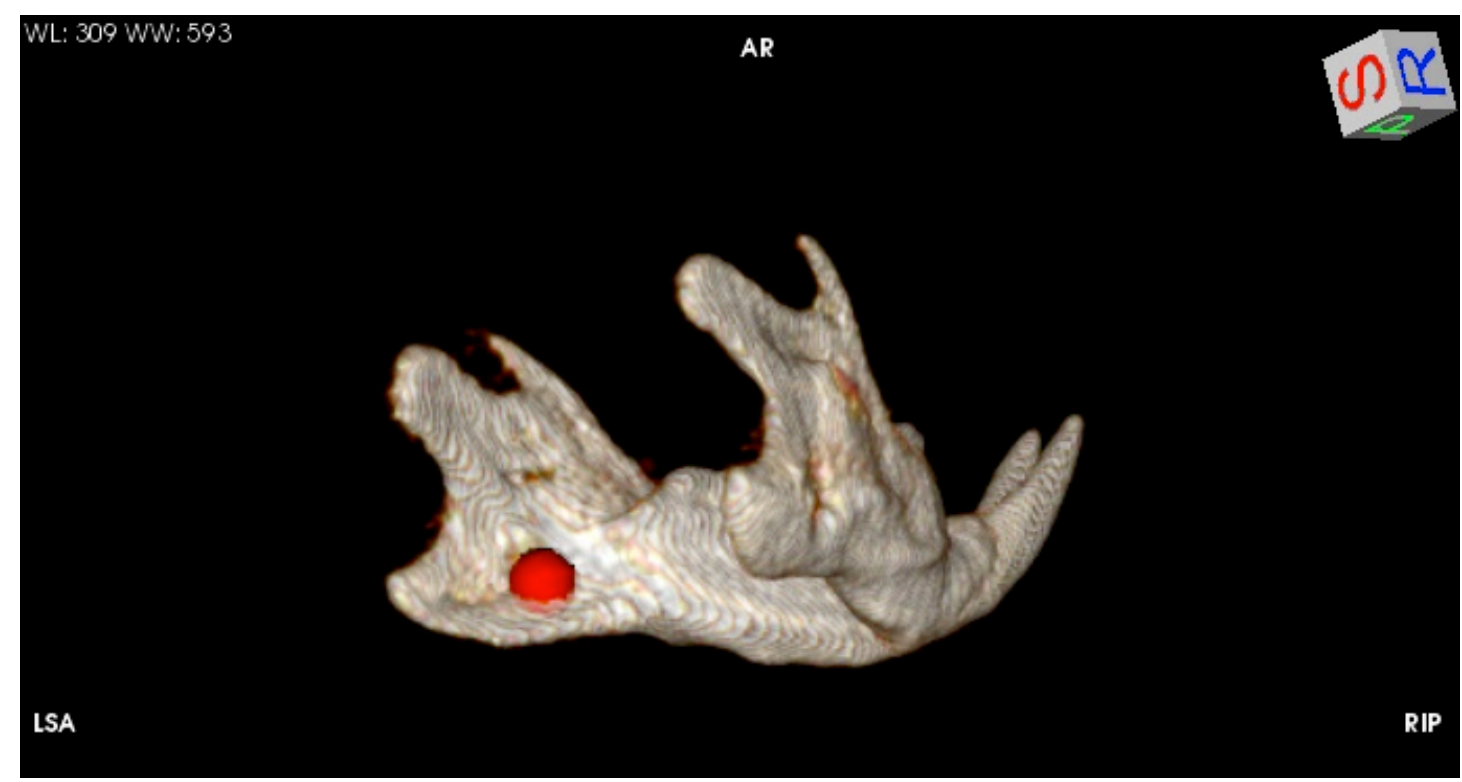

Ilustración 48. Imagen de mandíbula reconstruida con defecto marcado en color rojo.

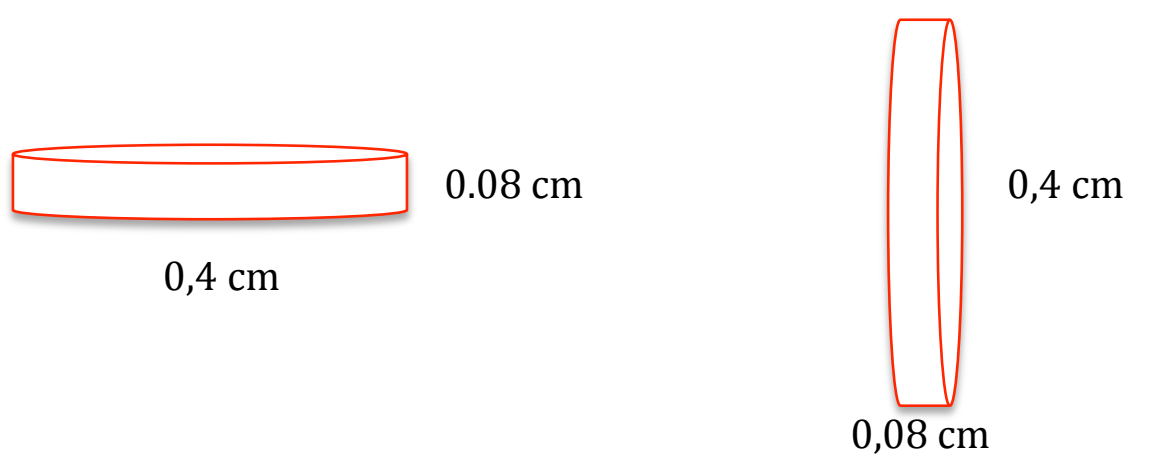

El software nos permite escoger un área concreta (ROI: Region of interest) y calcula la densidad radiológica media de dicho área en cada uno de los cortes que hemos establecido mediante reconstrucción multiplanar $(M P R)$, orientando cada uno de estos cortes respecto al eje mayor del cuerpo mandibular.

Para seleccionar los tres cortes posicionamos el punto de intersección de los 3 ejes en el centro del defecto y vamos desplazando dichos ejes hasta que coincidan con el eje 
mayor del cuerpo mandibular, de tal manera que al desplazar un eje en uno de los cortes, la imagen del resto de cortes se va modificando y adaptando a la posición seleccionada.

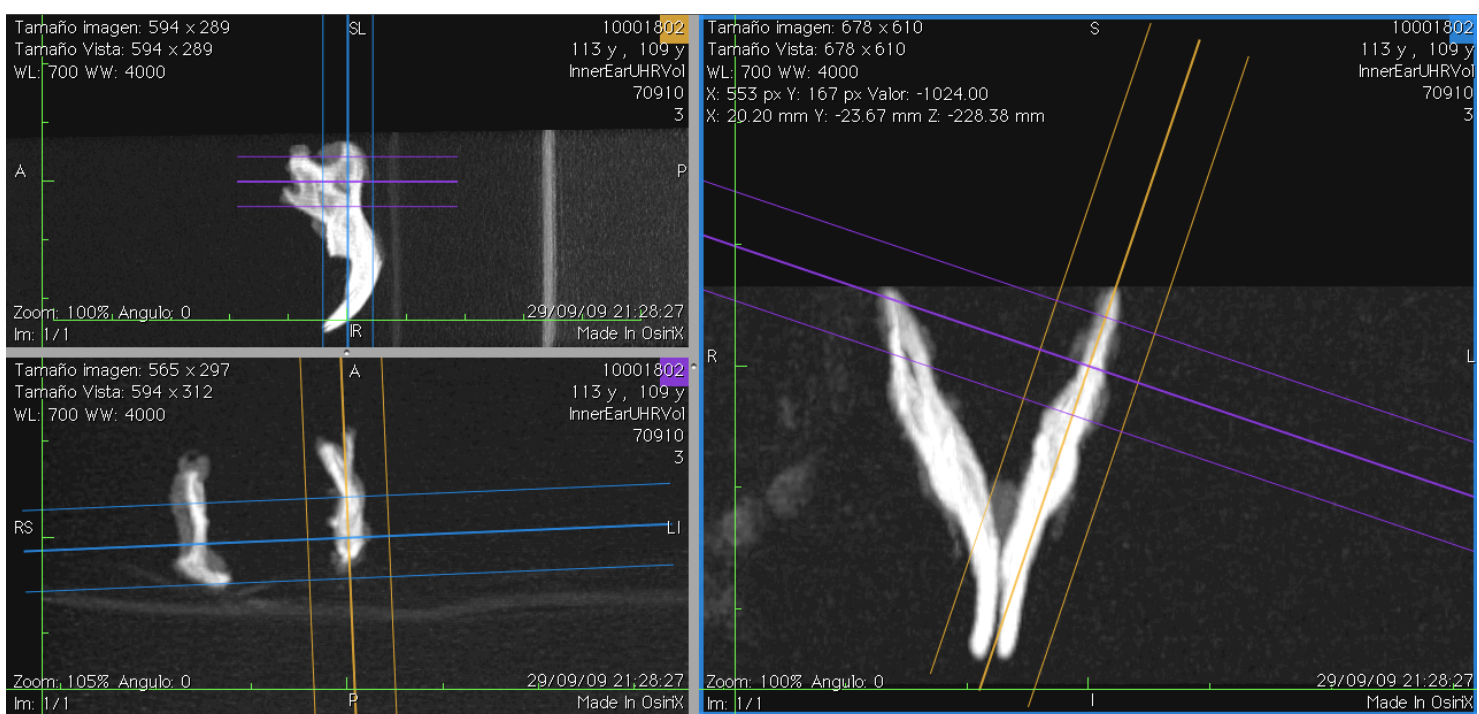

Ilustración 49. Reconstrucción MPR: sagital (arriba a la izquierda), coronal (abajo a la izquierda) y axial (derecha), en los que se sitúan los ejes en el cetro de la lesión.

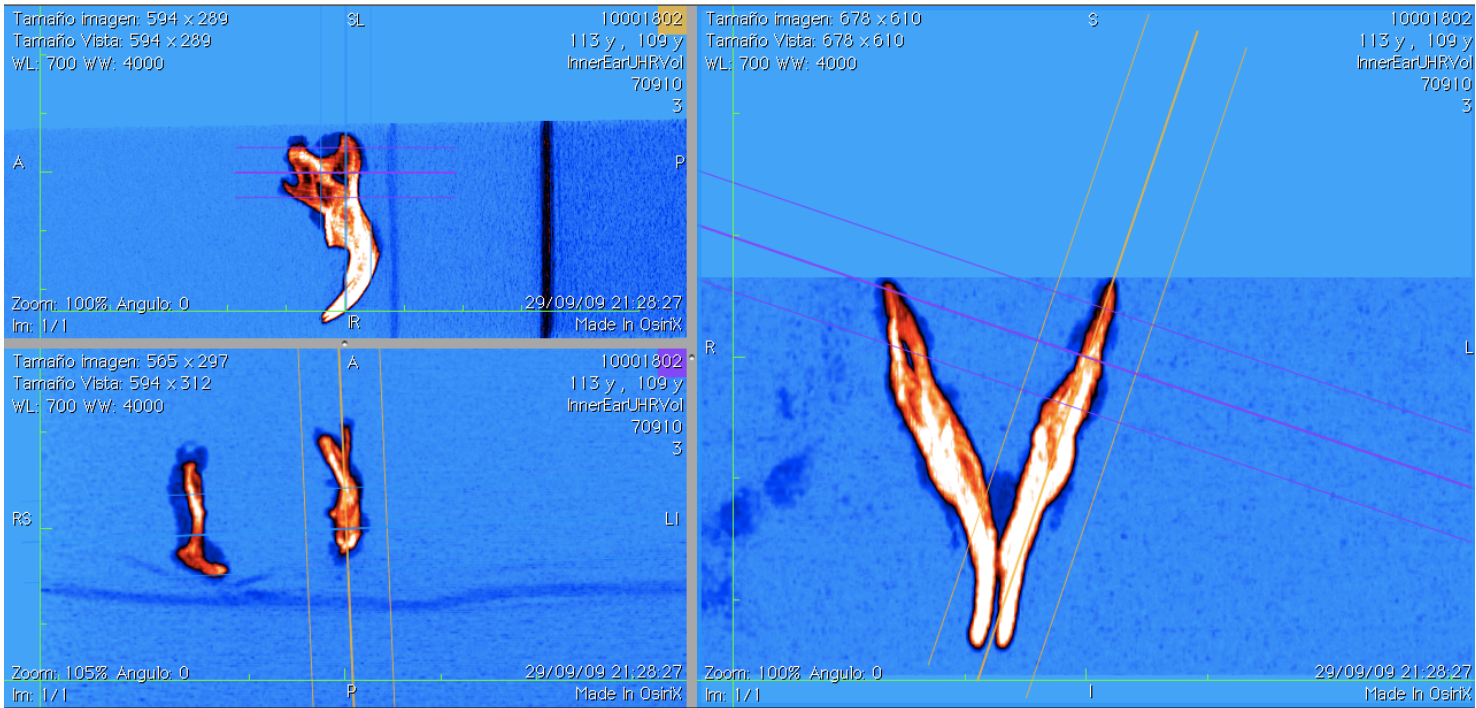

Ilustración 50. Misma imagen que la ilustración 49, en la que usando la herramienta $C L U T$ del programa, transformamos la imagen en escala de grises a $F L O W$, que permite observar un gradiente colorimétrico más ilustrativo.

Por tanto, para cada uno de los cortes calcularemos el área de estudio que se ajuste al defecto creado: 
En el corte sagital seleccionaremos un $R O I$ circular con un área de $0,125 \mathrm{~cm}^{2}(+/-$ 0,002) (ilustración 51 y 52), obtenido por la fórmula de área $=\pi r^{2}$
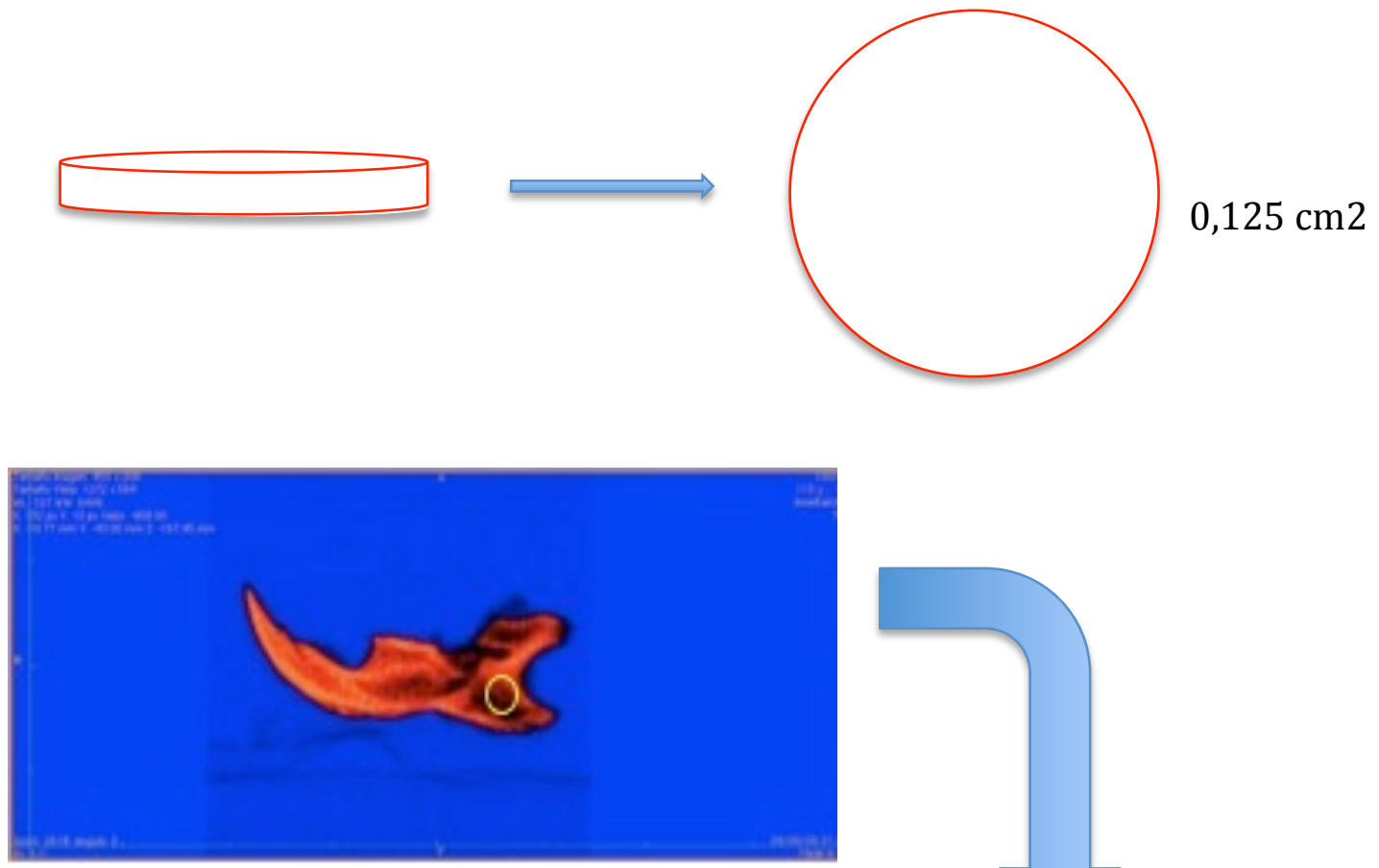

Ilustración 51. Corte sagital de mandíbula.

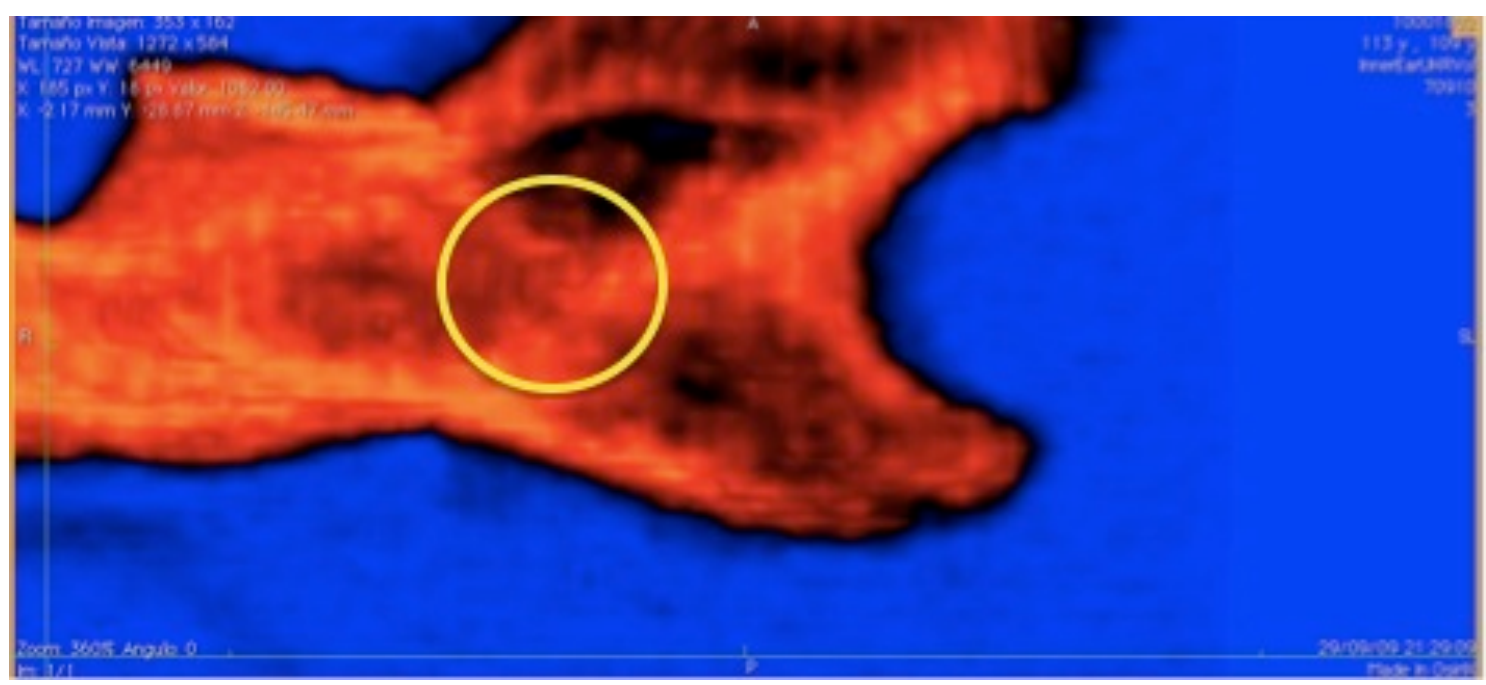

Ilustración 52. Aumento de la ilustración 51, donde se observa esquema del área circular a estudiar. 
En el corte coronal seleccionaremos un $R O I$ rectangular con un área de $0,032 \mathrm{~cm}^{2}(+/-$ 0,002) (ilustración 53 y 54), obtenido por la fórmula de área $=\mathrm{b} \times \mathrm{h}$
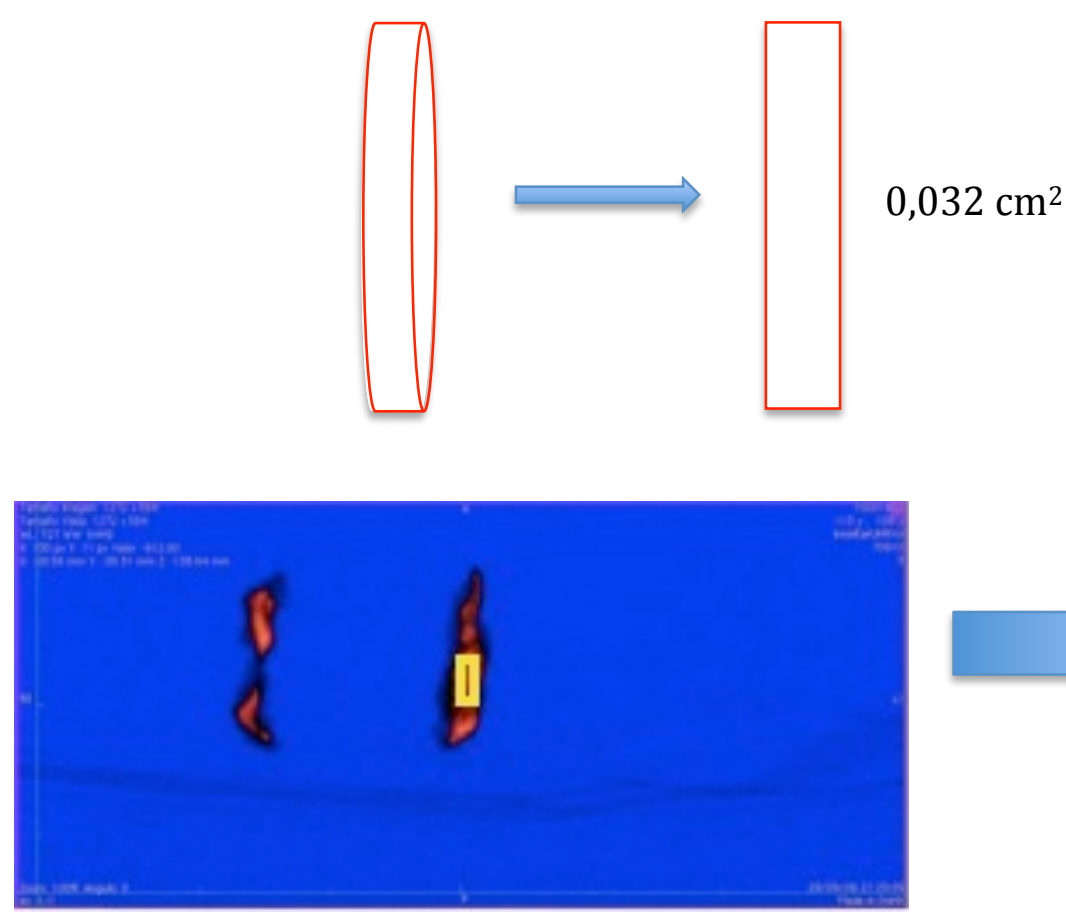

Ilustración 53. Corte coronal de mandíbular

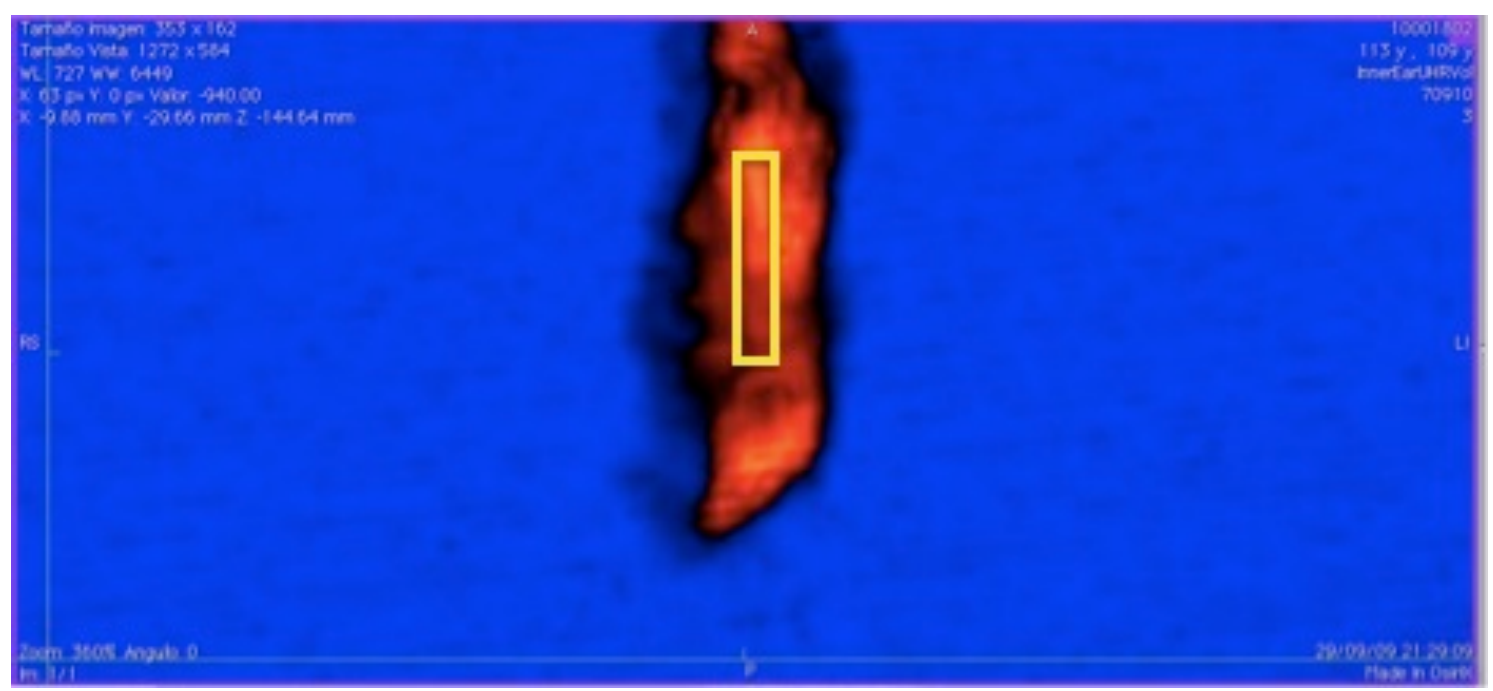

Ilustración 54. Aumento de la ilustración 53, en la que se observa hemimandíbula izquierda con representación esquemática del área rectangular a estudiar. 
En el corte axial seleccionaremos un $R O I$ rectangular con un área de $0,032 \mathrm{~cm}^{2}(+/-$ 0,002) (ilustración 55 y 56), obtenido por la fórmula de área $=\mathrm{b} \times \mathrm{h}$
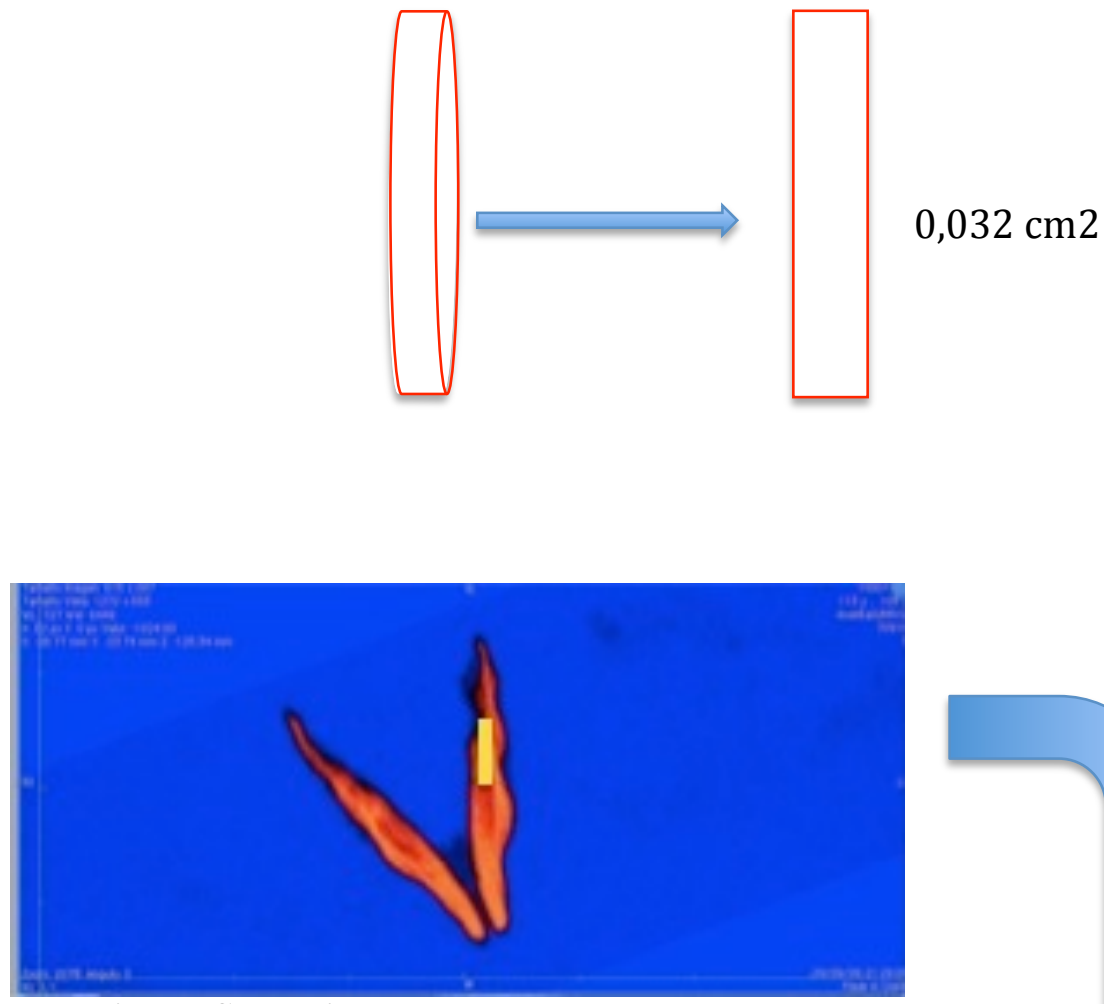

Ilustración 55. Corte axial de mandíbula.
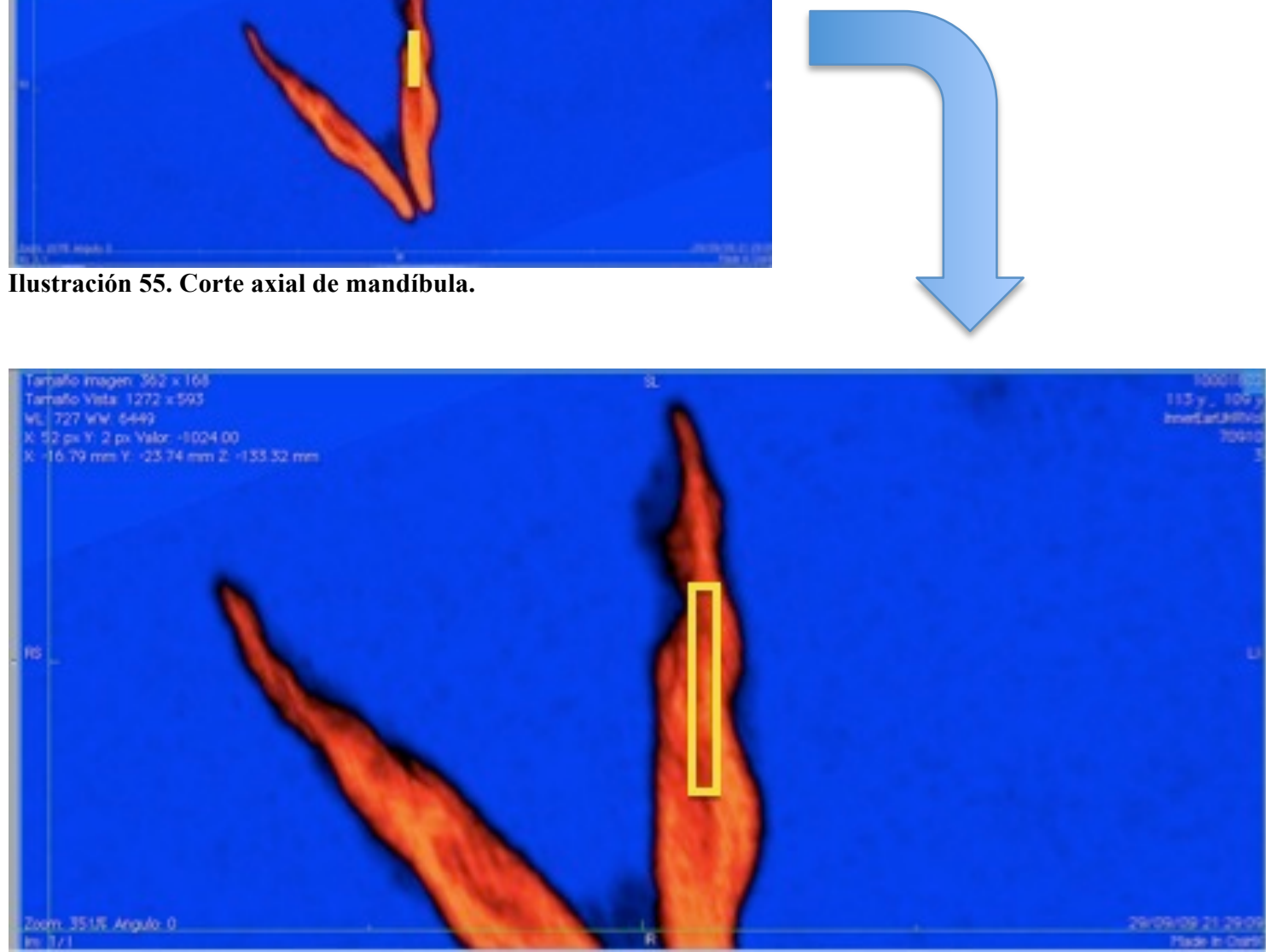

Ilustración 56. Aumento de ilustración 55, donde se observa esquema de área rectangular a estudiar en hemimandíbula izquierda.

Todas las mediciones de áreas, se llevaron a cabo en 2 ocasiones por 3 observadores diferentes para aumentar la fiabilidad de la medición y disminuir al máximo la posibilidad de aparición de errores del observador, obteniendo por tanto 6 valores para 
cada área en el plano sagital, 6 valores para cada área del plano coronal y 6 valores para el área del plano transversal. Las mediciones de los puntos se llevaron a cabo por 2 observadores diferentes en 2 ocasiones obteniendo 4 valores para el punto del área del plano sagital, 4 valores para un punto del área seleccionada en el plano coronal y 4 valores para el punto del área del plano transversal, esto nos sirvió para confirmar que el área seleccionado correspondía a la zona del defecto creado donde alojamos el injerto. Para corroborar esto mismo se midió por un tercer observador en 2 ocasiones puntos periféricos y alejados de la zona del injerto para conocer la densidad del hueso intacto, lo que llamaremos el punto $P H A$, obteniendo 2 valores para el punto $P H A$ en cada uno de los planos (sagital, coronal y transversal).

Todos estos valores de densidad radiológica obtenidos en cada una de las áreas estudiadas serán tratados estadísticamente.

\subsection{PROCESADO HISTOLÓGICO DE LAS MUESTRAS: VALORACIÓN MACROSCÓPICA Y MICROSCÓPICA}

\subsubsection{VALORACIÓN MACROSCÓPICA}

Durante el momento del sacrifico y disección de las muestras, se llevó a cabo una valoración descriptiva de los distintos hallazgos macroscópicos atendiendo a distintos parámetros:

- Organización anatómica de los tejidos.

- Consistencia y apariencia superficial del defecto.

- Presencia de infecciones, exudados o colecciones tisulares.

- Desplazamiento de la matriz del defecto.

- Presencia de fracturas: valorando la continuidad de hueso alrededor de todo 
el defecto creado.

- Cambios degenerativos dentarios.

- Secuestros óseos.

\subsubsection{VALORACIÓN MICROSCÓPICA}

Cada una de las hemimandíbulas con sus injertos fueron sumergidas en etanol al $70 \%$ durante 24 horas en frascos debidamente identificados. A continuación se procedió a su inclusión en metacrilato en el Instituto de Biología y Genética Molecular de Valladolid. La técnica de inclusión de las muestras óseas en una resina plástica basada en glicometacrilato permite estudiar muestras sin descalcificar preservando sus relaciones histológicas. Esta circunstancia hace posible valorar la calidad de la mineralización ósea y la relación entre los diferentes componentes del tejido óseo. La metodología llevada a cabo para conseguir estas preparaciones fue la siguiente:

1. Deshidratación y deslipidación. Se realizó a través de sucesivos lavados de los segmentos óseos por diferentes gradaciones de etanol y acetona:

- Etanol-acetona al 50\% durante 12 horas.

- Acetona durante 12 horas.

- Etanol-acetona al 50\% durante 12 horas.

- Etanol absoluto durante 24 horas.

2. Infiltración. Este proceso se efectuó con una resina plástica hidrosoluble basada en Glicolmetacrilato, $J B-4$ Plus ${ }^{\circledR}$, que impregna fácilmente el tejido óseo. Para conseguir esta resina se mezclaron $100 \mathrm{ml}$ de 2hidroxietilmetacrilato-polietilenglicol con 1 gramo de peróxido de 
benzolilo en polvo al 70\%, y fueron agitados manualmente hasta la disolución completa. Esta mezcla se conservó refrigerada a $4^{\circ} \mathrm{C}$ en un frasco de vidrio de paredes oscuras, herméticamente cerrado, durante 6 semanas. A continuación se colocaron las muestras óseas en tubos de vidrio que contienen la mezcla descrita para su infiltración durante 12 horas

3. Inclusión. Para llevar a cabo este último paso, se mezcló $15 \mathrm{ml}$ de la solución refrigerada, anteriormente descrita, con $1 \mathrm{ml}$ de solución derivada de pirimidenetrione. Inmediatamente se vertió la mezcla preparada en moldes de polietileno, donde se colocaron las muestras óseas debidamente identificadas. Sobre las muestras que se encontraban en proceso de inclusión, se instalaron bloques plásticos de contención, cerrando herméticamente los moldes, obteniendo así condiciones anaerobias.

La polimerización de la resina plástica basada en glicolmetacrilato se completó en aproximadamente 2 horas a temperatura ambiente. Transcurrido este periodo las muestras se retiran de los moldes.

4. Corte de las piezas. Los cortes histológicos de las muestras óseas útiles se realizaron con un microtomo específico de tejidos duros, obteniendo de este modo secciones de $5 \mu \mathrm{m}$ de espesor

Las muestras en metacrilato fueron posteriormente sometidos a estudio histológico mediante las tinciones de Hematoxilina-Eosina y Von Kossa. 


\section{TINCIÓN DE HEMATOXILINA-EOSINA:}

- Hematoxilina de Harris durante 5 minutos.

- Lavado con agua corriente durante 30 minutos.

- Inmersión en agua amoniacal.

- Lavado con agua corriente (10-20 minutos).

- Tinción con Eosina a temperatura ambiente.

- Inmersión en alcohol al 95\% para eliminar el exceso de Eosina.

- Deshidratación con etanol de graduación creciente: $70 \%$ durante 3 minutos, etanol al $80 \%$ durante 3 minutos y finalmente etanol al $96 \%$ durante 3 minutos más.

\section{TINCIÓN DE VON-KOSSA:}

- Nitrato de plata al 3\% durante 5 minutos.

- Dos lavado de 5 minutos con agua destilada.

- Formol-carbonato de socio durante 5 minutos.

- Agua corriente durante 10 minutos.

- Ponceau de xilidina durante 45 minutos.

- Lavado rápido con agua destilada.

- Ácido fosfotúngstico-Orange G durante 7 minutos.

- Lavado rápido con ácido acético al 1\%.

- Lavado rápido con agua destilada.

- Deshidratación y montaje.

Del mismo modo las muestras inguinales se sometieron al mismo proceso, obteniendo muestras en metacrilato que se sometieron a estudio histológico mediante tinciones de Hematoxilina-Eosina, Von Kossa y Giemsa. 


\section{GIEMSA:}

- Solución Giemsa al 20\% durante 45 minutos.

- Lavado con agua corriente durante 5-10 minutos.

- Inmersión rápida de etanol al 70\% 2 o 3 pases rápidos y alcohol al 96\% 2 o 3 pases rápidos.

- Alcohol isopropílico durante 3 minutos.

- Inmersión en xilol.

- Montaje en porta.

La finalidad del estudio de los injertos a nivel inguinal es obtener un estudio satélite del principal y valorar los procesos de regeneración ósea cuando los distintos scaffolds son aislados del tejido óseo y por tanto no están influenciados por el ambiente. De esta manera podemos valorar la potencia de cada uno de los injertos utilizados.

Las muestras ya preparadas se examinaron con microscopio óptico de luz Axiophot Cam HRc Zeiss obteniendo imágenes de distintos cortes que fueron fotografiadas. También se analizaron y obtuvieron imágenes con microscopio de luz polarizada. 


\subsection{ANÁLISIS ESTADÍSTICO}

Las variables cuantitativas se describen como media \pm desviación estándar (DE) y su normalidad se establece con la prueba de Kolmogorov-Smirnov. Por su parte, las variables cualitativas son descritas mediante frecuencias absolutas y relativas (porcentajes).

Finalmente se utilizan barras de error y diagramas de cajas para representar las variables cuantitativas

Para estudiar las diferencias entre medias se utiliza la prueba de la $t$ de Student o la $U$ de Mann-Whitney, dependiendo de las condiciones de aplicación. El nivel de significación se considera para una $\mathrm{p} \leq 0,05$.

Para demostrar una diferencia entre las medias de las áreas de 300 unidades de densidad (grupo control) frente a 600 unidades de densidad (resto de los grupos) con una significación del 5\%, la potencia ha sido establecida en $99 \%$

Se calculan los coeficientes de variación (CV\%) intra e interobservador para establecer la variabilidad de la medida.

El análisis estadístico se realizó con el programa SPSS v. 15.0 para Windows. 
IV. RESULTADOS 



\section{ESTUDIO ORTOTÓPICO}

\subsection{ESTUDIO RADIOLÓGICO.}

Todas las imágenes obtenidas en formato DICOM, tras someter las mandíbulas al estudio tomográfico, fueron analizadas con plataforma Osirix $X{ }^{\circledR}$, a partir de las cuales pudimos realizar un estudio densitométrico de las zonas del defecto en los 3 planos del espacio.

Al comparar las densidades de las zonas del defecto con las densidades de puntos aleatorios escogidos en la periferia del defecto $(P H A)$, observamos una menor densidad en todos los defectos de cada uno de los grupos. Por tanto en ningún caso la regeneración del defecto llega a completarse, y en todos ellos se aprecia una densidad radiológica menor en el defecto que en el hueso adyacente. El punto $P H A$ es un valor importante que nos asegura que el área escogida para estudio de las densidades pertenece al defecto y no se corresponde con un área de hueso periférico intacto.

Una vez procesadas las imágenes, y por tanto disponemos ya de los cortes, vamos a obtener los valores de la densidad media de cada una de las áreas, así como de puntos situados en dichas áreas. Los valores de las densidades medias de las áreas serán las que utilicemos para evaluar las diferentes densidades y que someteremos posteriormente al estudio estadístico. Los valores de las densidades de los puntos situados en el interior de dichas áreas, son valores aleatorios no representativos del proceso de regeneración, que se obtienen para asegurarnos que el área escogida corresponde al área del defecto realizado, objeto de estudio.

El estudio se lleva a cabo por tres observadores diferentes (obervador A, B y C), cada uno de los cuales va a realizar dos mediciones de áreas en los tres planos del espacio, 
obteniendo así seis mediciones por cada uno de los cortes de cada muestra. Del mismo modo se estudian puntos escogidos aleatoriamente dentro de las áreas por dos observadores diferentes, obteniendo cuatro valores para cada punto. De este modo se consigue por un lado minimizar el posible error del observador y por otro lado aumentar el número de valores que se someterán al estudio estadístico, obteniendo unos valores medios más fiables. La medición de los puntos nos ayuda a situarnos dentro del defecto y confirmar de este modo que el área escogida es precisamente el área que queremos medir. Es por ello que en una fase inicial de las mediciones de densidad procedemos a medir el valor de densidades escogidas aleatoriamente en la periferia del defecto (punto PHA), obteniendo unos valores en hueso intacto que oscilan entre 2400 y 3300 unidades de densidad radiológica (UDR) con equivalencia a unidades Hunsfield.

A continuación mostramos una serie de imágenes representativas de cada uno de los grupos, a partir de las cuales obtuvimos los valores de las densidades óseas de cada una de las áreas en los planos sagital, coronal y axial, a partir de las imágenes DICOM obtenidas mediante el estudio TC y que fueron analizadas mediante el software Osiri $X{ }^{\circledR}$ (ilustración 57, 58, 59 y 60). 


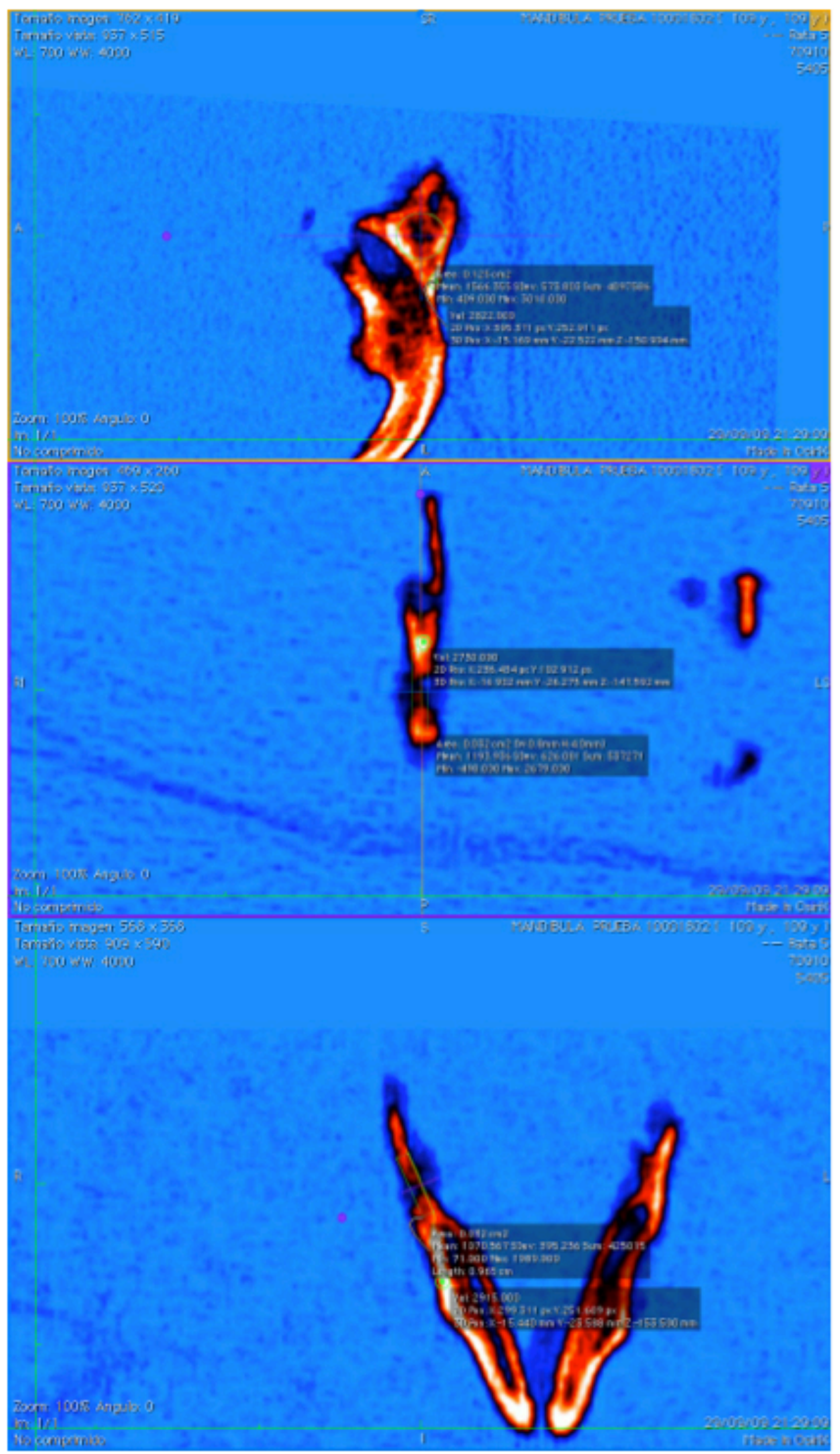

Ilustración 57. Medición de densidad ósea realizada por el observador $C$ de hemimandíbula derecha de rata no 5 (GRUPO I: scaffold con cultivo celular en medio osteogénico durante un día), donde se observa una medida de densidad ósea de 1566,35 para el círculo en el plano sagital, 1193,936 para el rectángulo en el plano coronal y 1070,567 para el rectángulo del plano axial. 


\section{RESULTADOS}
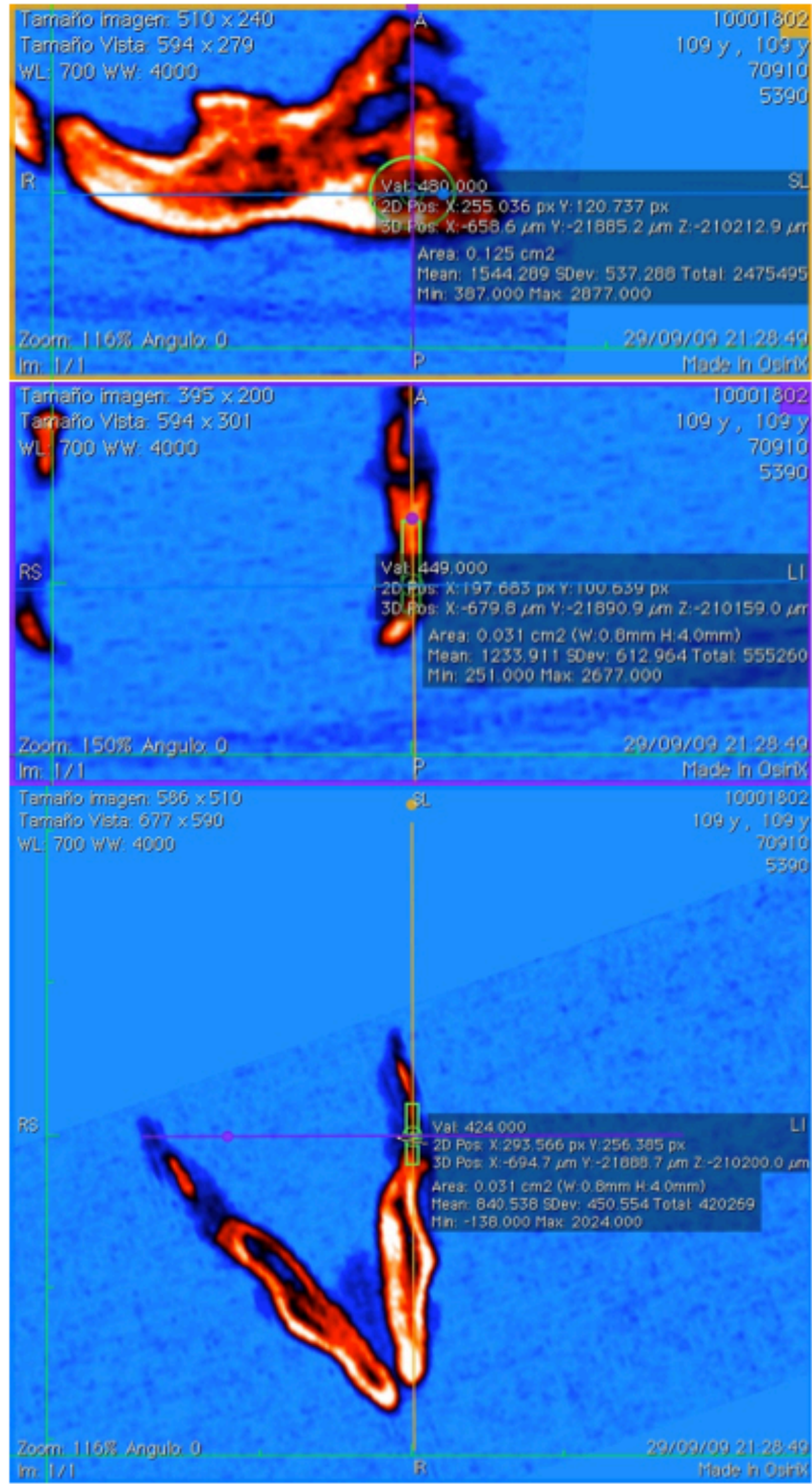

Ilustración 58. Medición de densidad ósea realizada por el observador B de hemimandíbula izquierda de rata no 3 (GRUPO II: GRUPO CONTROL: scaffold únicamente), donde se observa una medida de densidad ósea de 1544,289 para el círculo en el plano sagital, 1231,911 para el rectángulo en el plano coronal y 840,538 para el rectángulo del plano axial. 


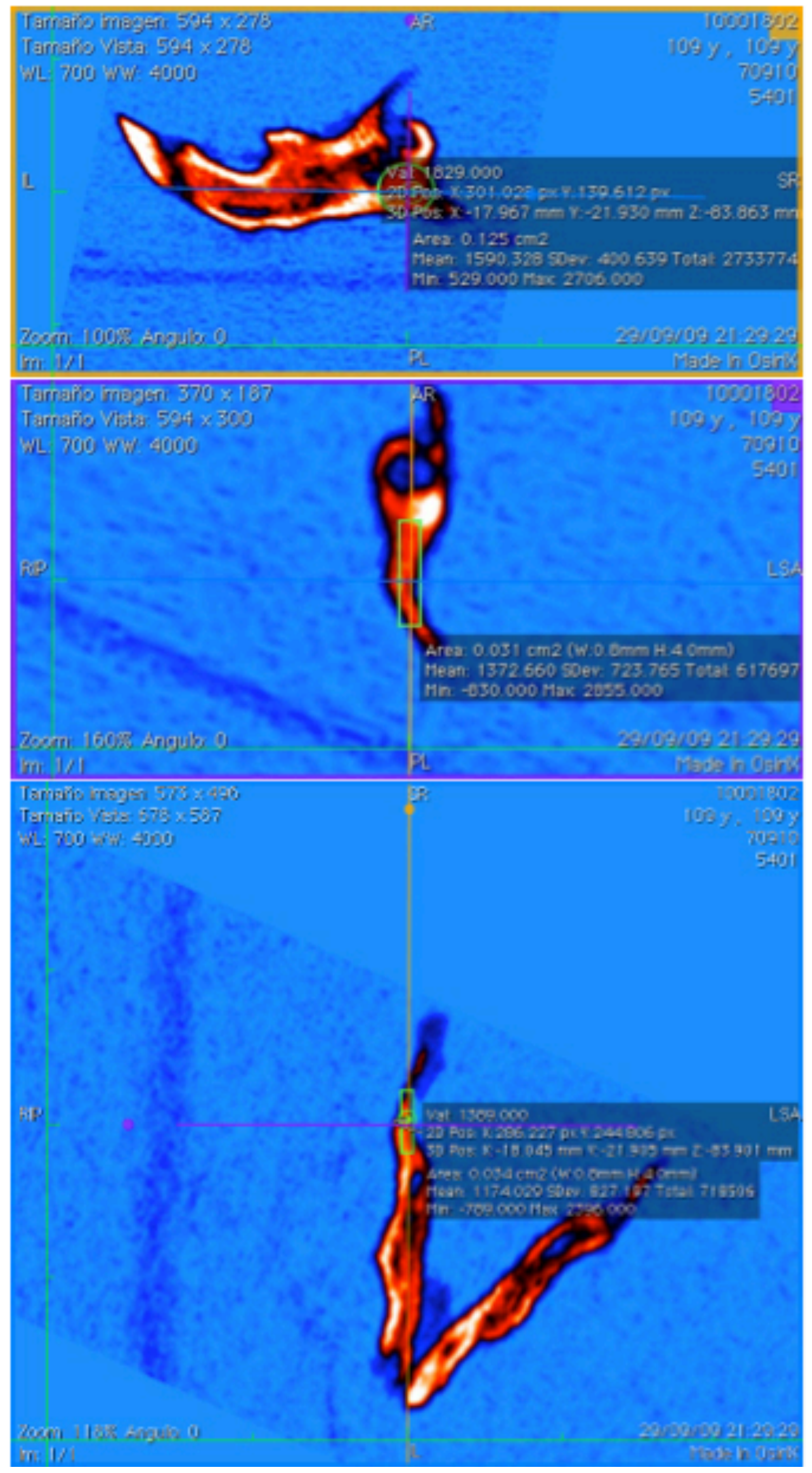

Ilustración 59. Medición de densidad ósea realizada por el observador B de hemimandíbula derecha de rata no 9 (GRUPO III: scaffold con células cultivadas durante 21 días en medio osteogénico), donde se observa una medida de densidad ósea de 1590,328 para el círculo en el plano sagital, 1372,660 para el rectángulo en el plano coronal y 1174,029 para el rectángulo del plano axial. 


\section{RESULTADOS}

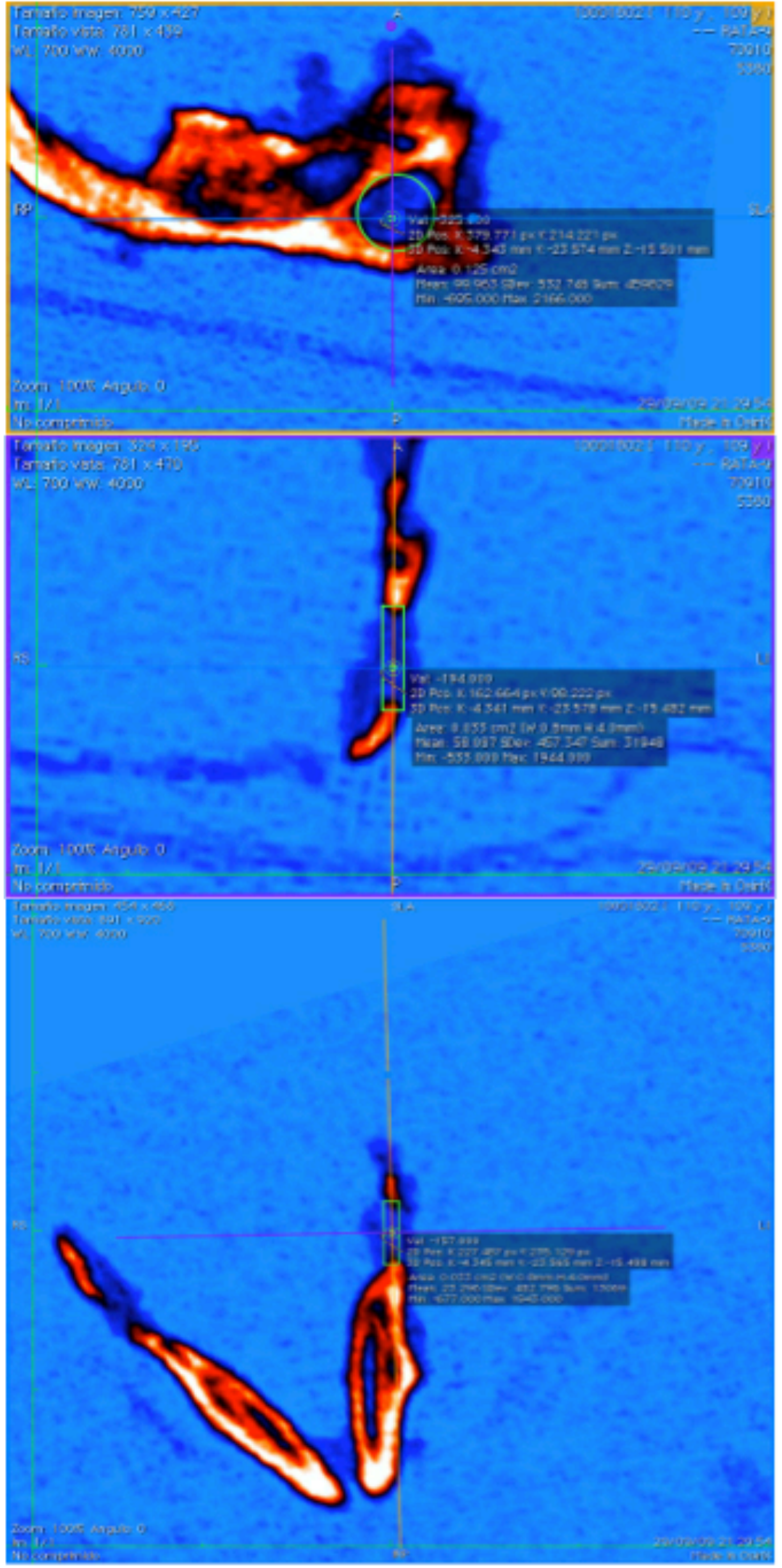

Ilustración 60. Medición de densidad ósea realizada por el observador A de hemimandíbula izquierda de rata no 11 (GRUPO IV: scaffold con cultivo celular de 21 días en medio no osteogénico), donde se observa una medida de densidad ósea de 99,963 para el círculo en el plano sagital, 58,087 para el rectángulo en el plano coronal y 23,296 para el rectángulo del plano axial. 
A continuación se muestran, en las siguientes tablas, las mediciones tanto de las distintas áreas estudiadas en los tres planos del espacio realizadas por 3 observadores diferentes (tablas 3-10), como de los puntos dentro de dichas áreas realizadas por 2 observadores diferentes (tabla 1) y el punto PHA (punto escogido aleatoriamente por el tercer observador en mandíbula intacta, alejado de la zona del defecto), realizada por un solo observador (tabla 2). Para hacer más sencilla e intuitiva su comprensión hemos asignado a cada área y punto un color que es el que establece el programa osiri $X ®$ por defecto a cada uno de los cortes, de tal manera que:

- El punto/área 1 corresponde al corte sagital y viene codificado en color naranja.

- El punto/área 2 corresponde al corte coronal y viene codificado en color morado.

- El punto/área 3 corresponde al corte transversal y viene codificado en color azul. 


\section{Resultados de las mediciones de los puntos situados en el área seleccionada}

\begin{tabular}{|c|c|c|c|c|c|c|c|}
\hline RATA & Observador & $\begin{array}{l}\text { PUNTO-1- } \\
\text { DER } \\
\end{array}$ & $\begin{array}{l}\text { PUNTO-1- } \\
\text { IZQ }\end{array}$ & $\begin{array}{l}\text { PUNTO-2- } \\
\text { DER }\end{array}$ & $\begin{array}{l}\text { PUNTO-2- } \\
\text { IZQ }\end{array}$ & $\begin{array}{l}\text { PUNTO-3- } \\
\text { DER }\end{array}$ & $\begin{array}{l}\text { PUNTO- } \\
3-I Z Q\end{array}$ \\
\hline \multirow{6}{*}{1} & $\mathrm{~A}$ & 1783 & 23 & 1775 & 203 & 1724 & 239 \\
\hline & $\mathrm{A}$ & 1780 & 159 & 1824 & -49 & 1745 & 157 \\
\hline & $\mathrm{B}$ & 1397 & 269 & 1359 & 105 & 1338 & -9 \\
\hline & $\mathrm{B}$ & 937 & 191 & 1159 & 134 & 1023 & 113 \\
\hline & MEDIA & 1474,3 & 160,5 & 1529,3 & 98,3 & 1457,5 & 125,0 \\
\hline & DE & 401,4 & 102,6 & 323,2 & 106,4 & 344,8 & 103,5 \\
\hline \multirow{6}{*}{2} & $\mathrm{~A}$ & 110 & 200 & -74 & 212 & -373 & 471 \\
\hline & $\mathrm{A}$ & 183 & 413 & 471 & 623 & 467 & 695 \\
\hline & $\mathrm{B}$ & 726 & 847 & 675 & 1383 & 558 & 1197 \\
\hline & $\mathrm{B}$ & 526 & 636 & 445 & 402 & 597 & 558 \\
\hline & MEDIA & 386,3 & 524,0 & 379,3 & 655,0 & 312,3 & 730,3 \\
\hline & DE & 290,2 & 279,4 & 319,2 & 513,6 & 460,1 & 324,5 \\
\hline \multirow{6}{*}{3} & $\mathrm{~A}$ & 183 & 550 & 186 & 672 & 144 & 442 \\
\hline & $\mathrm{A}$ & 183 & 413 & 471 & 623 & 467 & 695 \\
\hline & $\mathrm{B}$ & 151 & 769 & 380 & 706 & 286 & 656 \\
\hline & $\mathrm{B}$ & 100 & 450 & 110 & 449 & 82 & 424 \\
\hline & MEDIA & 154,3 & 545,5 & 286,8 & 612,5 & 244,8 & 554,3 \\
\hline & DE & 39,2 & 159,8 & 167,4 & 114,2 & 171,0 & 141,1 \\
\hline \multirow{6}{*}{4} & $\mathrm{~A}$ & 260 & 215 & 39 & 481 & 441 & 427 \\
\hline & $\mathrm{A}$ & 150 & 948 & 182 & 781 & 476 & 1007 \\
\hline & $\mathrm{B}$ & 27 & 204 & 4 & -19 & 94 & -71 \\
\hline & $\mathrm{B}$ & 160 & 511 & 1325 & 667 & 1388 & 347 \\
\hline & MEDIA & 149,3 & 469,5 & 387,5 & 477,5 & 599,8 & 427,5 \\
\hline & DE & 95,4 & 349,3 & 629,7 & 353,3 & 553,1 & 443,8 \\
\hline \multirow{6}{*}{5} & $\mathrm{~A}$ & 836 & 654 & 726 & 689 & 389 & 601 \\
\hline & $\mathrm{A}$ & 658 & 668 & 574 & 540 & 740 & 798 \\
\hline & $\mathrm{B}$ & 1189 & 719 & 992 & 1126 & 1315 & 1024 \\
\hline & $\mathrm{B}$ & 504 & 1147 & 356 & 1131 & 485 & 1013 \\
\hline & MEDIA & 796,8 & 797,0 & 662,0 & 871,5 & 732,3 & 859,0 \\
\hline & DE & 294,6 & 235,0 & 267,3 & 302,9 & 415,8 & 201,0 \\
\hline \multirow{6}{*}{6} & $\mathrm{~A}$ & 1791 & 86 & 1807 & 69 & 1738 & 129 \\
\hline & $\mathrm{A}$ & 1497 & 1641 & 1429 & 1608 & 1401 & 1755 \\
\hline & $\mathrm{B}$ & 1805 & 1043 & 1614 & 456 & 1658 & 512 \\
\hline & $\mathrm{B}$ & 1483 & 684 & 1622 & 1221 & 1481 & 1372 \\
\hline & MEDIA & 1644,0 & 863,5 & 1618,0 & 838,5 & 1569,5 & 942,0 \\
\hline & DE & 178,00 & 65152 & 154,35 & 701,63 & 155,40 & 750,94 \\
\hline \multirow{6}{*}{7} & $\mathrm{~A}$ & 2071 & 652 & 1988 & 400 & 1857 & 375 \\
\hline & $\mathrm{A}$ & 2048 & 659 & 2086 & 614 & 1925 & 587 \\
\hline & $\mathrm{B}$ & 2100 & 516 & 1924 & 538 & 1952 & 571 \\
\hline & $\mathrm{B}$ & 1668 & 729 & 1594 & 579 & 1569 & 544 \\
\hline & MEDIA & 1971,8 & 639,0 & 1898,0 & 532,8 & 1825,8 & 519,3 \\
\hline & DE & 203,6 & 89,1 & 213,3 & 93,8 & 175,8 & 97,8 \\
\hline \multirow{6}{*}{9} & A & 1774 & -802 & 1720 & -825 & 1904 & -733 \\
\hline & A & 1632 & -376 & 1739 & -420 & 1627 & -420 \\
\hline & $\mathrm{B}$ & 1829 & -423 & 1723 & -196 & 1389 & -309 \\
\hline & $\mathrm{B}$ & 2044 & -365 & 1790 & -368 & 1859 & -381 \\
\hline & MEDIA & 1819,8 & $-491,5$ & 1743,0 & 452,3 & 1694,8 & $-460,8$ \\
\hline & DE & 171,0 & 208,5 & 32,4 & 266,3 & 237,2 & 187,2 \\
\hline \multirow{6}{*}{10} & $\mathrm{~A}$ & 268 & 562 & 271 & 400 & 226 & 235 \\
\hline & $\mathrm{A}$ & 282 & 411 & 281 & 177 & 299 & 62 \\
\hline & $\mathrm{B}$ & 164 & 263 & 102 & 216 & 128 & 243 \\
\hline & $\mathrm{B}$ & 493 & -98 & 416 & 23 & 417 & 65 \\
\hline & MEDIA & 301,8 & 284,5 & 267,5 & 204,0 & 267,5 & 151,3 \\
\hline & DE & 137,9 & 282,7 & 128,6 & 155,0 & 121,8 & 101,4 \\
\hline \multirow{6}{*}{11} & $\mathrm{~A}$ & 140 & -286 & 25 & -412 & -23 & -189 \\
\hline & $\mathrm{A}$ & 904 & -325 & 1059 & -194 & 1102 & -157 \\
\hline & B & 94 & -419 & 74 & -284 & 56 & -269 \\
\hline & $\mathrm{B}$ & 85 & -74 & 102 & -194 & 96 & -84 \\
\hline & MEDIA & 305,8 & $-276,0$ & 315,0 & 1,0 & 307,8 & $-174,8$ \\
\hline & DE & 399,6 & 145,8 & 497,0 & 103,1 & 531,8 & 76,7 \\
\hline \multirow{6}{*}{12} & $\mathrm{~A}$ & 659 & -312 & 465 & -248 & 436 & -134 \\
\hline & A & 2196 & 848 & 2071 & 1301 & 2078 & 1237 \\
\hline & $\mathrm{B}$ & 1296 & 124 & 1101 & 936 & 789 & 96 \\
\hline & $\mathrm{B}$ & 1559 & 412 & 1435 & 117 & 1725 & 1007 \\
\hline & MEDIA & 1427,5 & 268,0 & 1268,0 & 526,5 & 1257,0 & 551,5 \\
\hline & DE & 636,59 & 487,94 & 669,67 & 715,32 & 771,60 & 670,00 \\
\hline
\end{tabular}

Tabla 1. Mediciones llevadas a cabo por el observador A y B de los puntos situados en las áreas de estudio en los tres planos del espacio, así como las medias y desviación estándar (DE) de los mismas. 


\section{Resultados de las mediciones del punto $P H A$}

\begin{tabular}{|c|c|c|c|c|c|c|c|}
\hline Rata & $\begin{array}{l}\text { Observad } \\
\text { or }\end{array}$ & $\begin{array}{l}\text { PH-A-1- } \\
\text { DER }\end{array}$ & $\begin{array}{l}\text { PH-A-1- } \\
\text { IZQ }\end{array}$ & $\begin{array}{l}\text { PH-A-2- } \\
\text { DER }\end{array}$ & $\begin{array}{l}\text { PH-A-2- } \\
\text { IZQ }\end{array}$ & $\begin{array}{l}\text { PH-A-3- } \\
\text { DER }\end{array}$ & \begin{tabular}{|l} 
PH-A-3- \\
IZQ \\
\end{tabular} \\
\hline \multirow[b]{2}{*}{1} & \multirow{22}{*}{ C } & 2333 & 2839 & 2767 & 2673 & 2908 & 2554 \\
\hline & & 2269 & 2673 & 2565 & 2600 & 2811 & 2478 \\
\hline \multirow[b]{2}{*}{2} & & 2690 & 2639 & 2814 & 2521 & 2683 & 2675 \\
\hline & & 2902 & 2672 & 2700 & 2652 & 2619 & 2522 \\
\hline \multirow[b]{2}{*}{3} & & 2796 & 2723 & 2617 & 2528 & 2501 & 2753 \\
\hline & & 2860 & 2681 & 2532 & 2557 & 2627 & 2791 \\
\hline \multirow[b]{2}{*}{4} & & 2792 & 2714 & 2729 & 2718 & 2766 & 2735 \\
\hline & & 2562 & 2627 & 2674 & 2815 & 2660 & 2444 \\
\hline \multirow[b]{2}{*}{5} & & 2822 & 2620 & 2730 & 2747 & 2915 & 2616 \\
\hline & & 2844 & 2793 & 2713 & 2604 & 2828 & 2553 \\
\hline \multirow[b]{2}{*}{6} & & 2658 & 2798 & 2660 & 2676 & 2608 & 2611 \\
\hline & & 2701 & 2805 & 2708 & 2890 & 2823 & 2673 \\
\hline \multirow[b]{2}{*}{7} & & 2939 & 2666 & 2960 & 2605 & 2709 & 2155 \\
\hline & & 2407 & 2694 & 2377 & 2689 & 2445 & 2568 \\
\hline \multirow[b]{2}{*}{9} & & 2993 & 2366 & 2670 & 2419 & 2683 & 2518 \\
\hline & & 2245 & 2415 & 2935 & 2622 & 2440 & 2939 \\
\hline \multirow[b]{2}{*}{10} & & 2642 & 2606 & 2733 & 2751 & 2599 & 2525 \\
\hline & & 2761 & 2655 & 2688 & 2759 & 2459 & 2679 \\
\hline \multirow[b]{2}{*}{11} & & 2684 & 2701 & 2874 & 2598 & 2723 & 2765 \\
\hline & & 2654 & 2734 & 2879 & 2845 & 2854 & 2900 \\
\hline \multirow[b]{2}{*}{12} & & 2764 & 2564 & 2384 & 2658 & 2598 & 2863 \\
\hline & & 2658 & 2804 & 2456 & 2798 & 2435 & 2668 \\
\hline
\end{tabular}

Tabla 2. Mediciones del punto PHA (puntos escogidos aleatoriamente alejados de la zona del defecto) llevadas a cabo por el observador $C$. Observamos valores elevados de densidad en todos los casos ya que son medias de puntos escogidos aleatoriamente alejados del defecto en zonas de hueso intacto. 


\section{Resultados de las mediciones de las densidades medias de las áreas en el grupo I}

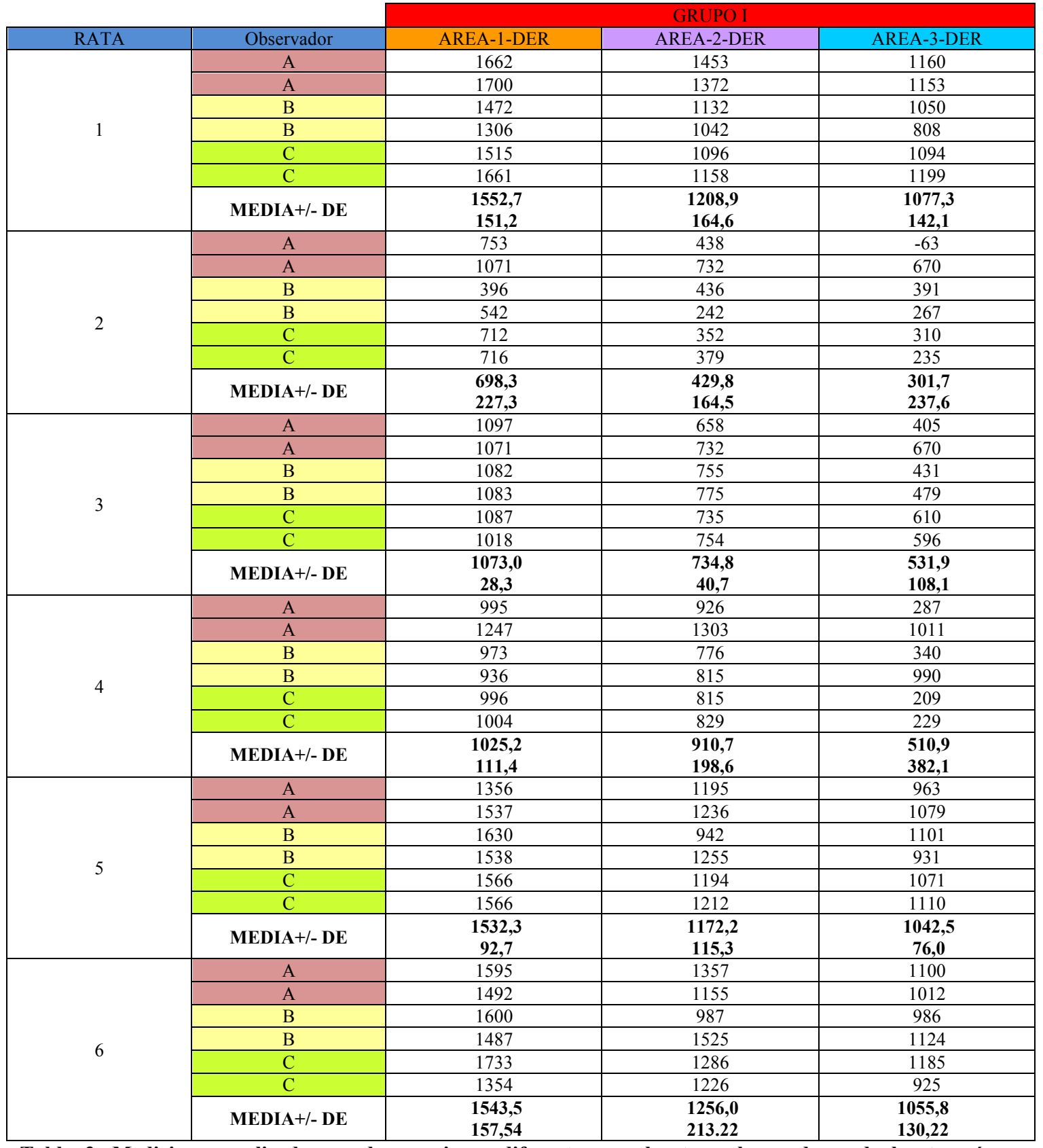

Tabla 3. Mediciones realizadas en dos ocasiones diferentes por los tres observadores de las tres áreas seleccionadas (corte sagital, corte coronal y corte axial) del grupo I (hemimandíbula derecha de los animales 1 , 2, 3, 4, 5 y 6: injerto con scaffold sembrado con células un día de cultivo). Media y desviación estándar (DE) de cada una de las áreas en cada plano del espacio calculadas a partir de 6 valores medidos por 3 observadores diferentes.

\begin{tabular}{|c|c|c|c|}
\hline & \multicolumn{3}{|c|}{ GRUPO I } \\
\hline & AREA-1-DER & AREA-2-DER & AREA-3-DER \\
\hline MEDIA +/- DE & $1237 \pm 358$ & $952 \pm 325$ & $753 \pm 344$ \\
\hline MEDIANA (RANGO) & $1276,5(1000-1552)$ & $964,5(744,5-1219)$ & $928(398-1086,5)$ \\
\hline \multicolumn{4}{|c|}{$\begin{array}{l}\text { Tabla 4. Medias y desviación estándar, medianas y rangos de valores obtenidos a partir de todas las } \\
\text { mediciones realizadas por los tres observadores en los planos sagital (ÁREA-1-DER), coronal (ÁREA-2-DER) } \\
\text { y axial (ÁREA-3-DER) de los animales pertenecientes al grupo I (hemimandíbula derecha con scaffold } \\
\text { cultivado con células durante } 1 \text { día). Estos son los valores que utilizaremos para llevar a cabo la comparación } \\
\text { entre los diferentes grupos. }\end{array}$} \\
\hline
\end{tabular}


RESULTADOS

\section{Resultados de las mediciones de las densidades medias de las áreas en el grupo}

\section{II: GRUPO CONTROL}

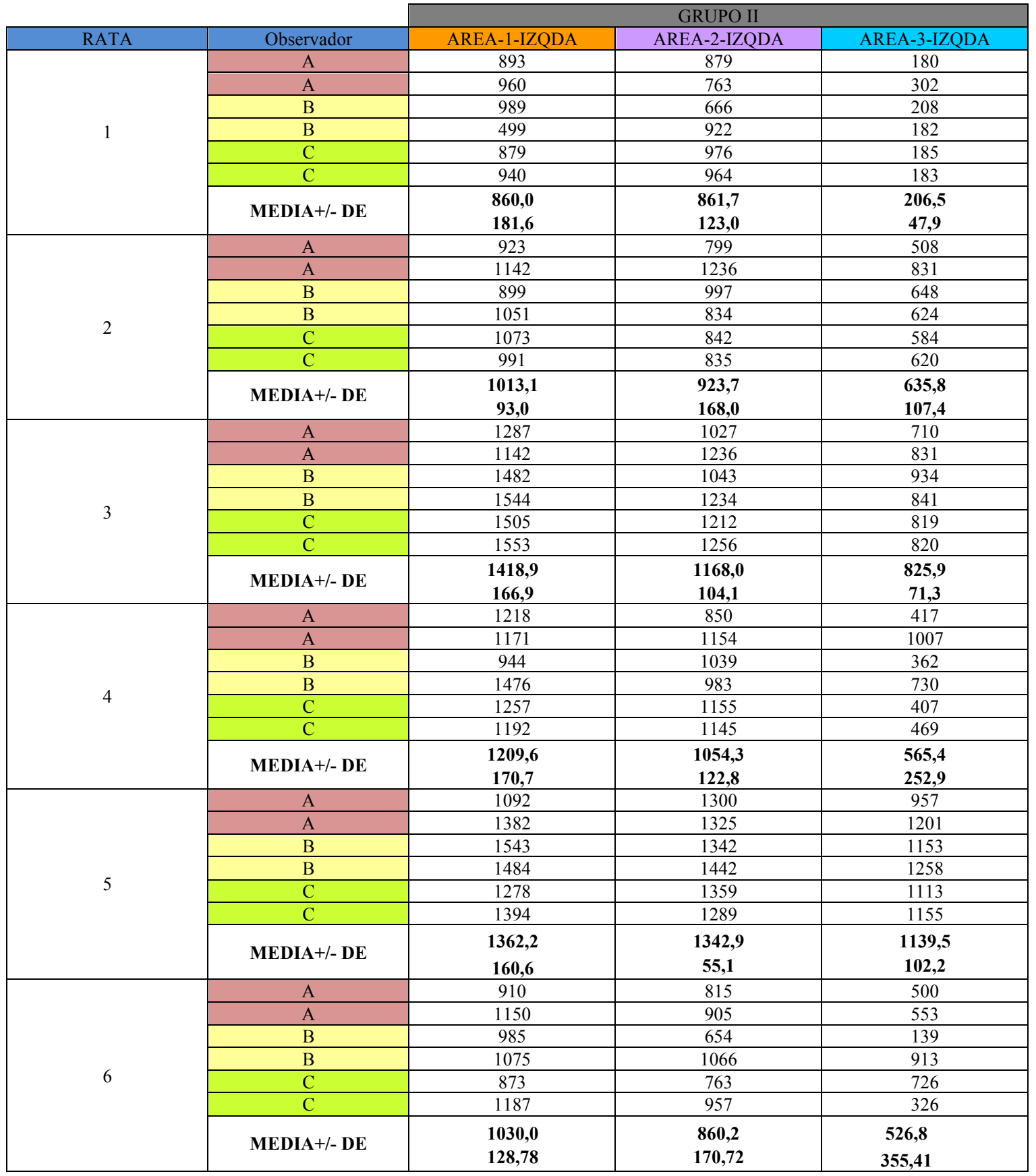

Tabla 5. Mediciones realizadas en dos ocasiones diferentes por los tres observadores de las tres áreas seleccionadas (corte sagital, corte coronal y corte axial) del grupo II (GRUPO CONTROL) (hemimandíbula izquierda de los animales $1,2,3,4,5$ y 6: injerto con scaffold sólo). Media y desviación estándar (DE) de cada una de las áreas de cada animal.

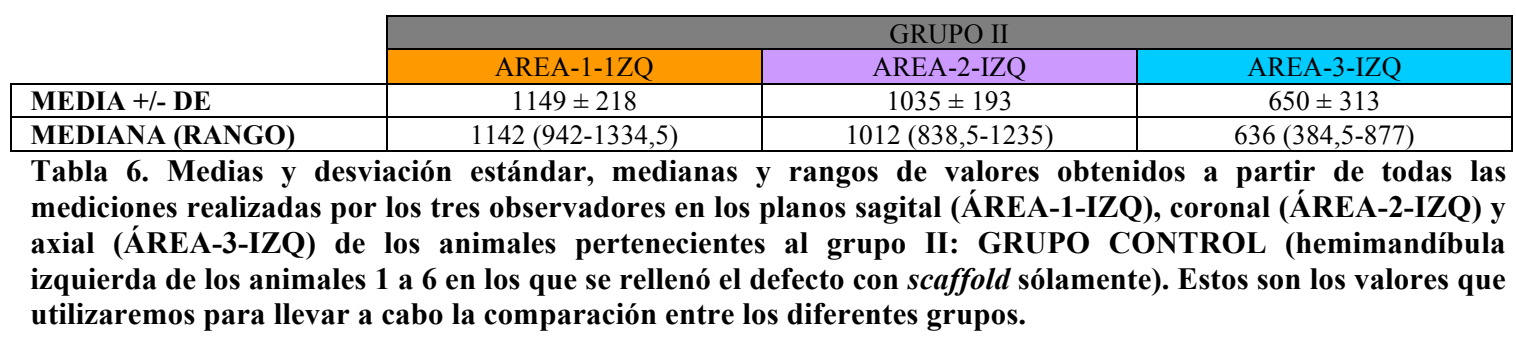




\section{Resultados de las mediciones de las densidades medias de las áreas del grupo III}

\begin{tabular}{|c|c|c|c|c|}
\hline & & & GRUPO III & \\
\hline RATA & Observador & AREA-1-DER & AREA-2-DER & AREA-3-DER \\
\hline \multirow{8}{*}{7} & $\mathrm{~A}$ & 1729 & 1174 & 1733 \\
\hline & $\mathrm{A}$ & 1790 & 1413 & 1493 \\
\hline & $\mathrm{B}$ & 1709 & 1275 & 1707 \\
\hline & $\mathrm{B}$ & 1726 & 1458 & 1378 \\
\hline & $\mathrm{C}$ & 1696 & 1462 & 1755 \\
\hline & $\mathrm{C}$ & 2014 & 1483 & 1440 \\
\hline & MEDIA+/- DE & & & 1584,4 \\
\hline & של של & 120,2 & 124,7 & 166,2 \\
\hline \multirow{8}{*}{9} & $\mathrm{~A}$ & 1479 & 678 & 1001 \\
\hline & $\mathrm{A}$ & 1602 & 1474 & 1515 \\
\hline & $\mathrm{B}$ & 1590 & 1373 & 1174 \\
\hline & $\mathrm{B}$ & 1607 & 872 & 854 \\
\hline & $\mathrm{C}$ & 701 & 292 & 687 \\
\hline & $\mathrm{C}$ & 717 & 336 & 531 \\
\hline & MEDIA+/- DE & & 837,6 & 960,2 \\
\hline & 年 & 446,9 & 503,4 & 353,8 \\
\hline \multirow{8}{*}{10} & A & 1033 & 625 & 549 \\
\hline & $\mathrm{A}$ & 1048 & 695 & 631 \\
\hline & $\mathrm{B}$ & 1104 & 541 & 732 \\
\hline & $\mathrm{B}$ & 799 & 423 & 623 \\
\hline & $\mathrm{C}$ & 1031 & 613 & 660 \\
\hline & $\mathrm{C}$ & 1004 & 612 & 640 \\
\hline & MEDIA+/- DE & 1003,2 & 584,8 & 639,1 \\
\hline & 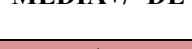 & 105,4 & 93,2 & 59,2 \\
\hline \multirow{8}{*}{11} & $\mathrm{~A}$ & 1088 & 653 & 513 \\
\hline & $\mathrm{A}$ & 1166 & 880 & 806 \\
\hline & $\mathrm{B}$ & 923 & 688 & 631 \\
\hline & $\mathrm{B}$ & 1104 & 744 & 494 \\
\hline & $\mathrm{C}$ & 973 & 657 & 450 \\
\hline & $\mathrm{C}$ & 988 & 662 & 499 \\
\hline & MEDIA+/- DE & 1040,4 & 714,0 & 565,6 \\
\hline & & 92,9 & 88,1 & 132,4 \\
\hline \multirow{8}{*}{12} & $\mathrm{~A}$ & 1248 & 971 & 1002 \\
\hline & $\mathrm{A}$ & 1468 & 1194 & 1224 \\
\hline & $\mathrm{B}$ & 1200 & 987 & 763 \\
\hline & $\mathrm{B}$ & 1516 & 1178 & 1463 \\
\hline & $\mathrm{C}$ & 1612 & 493 & 1094 \\
\hline & $\mathrm{C}$ & 1104 & 1672 & 1132 \\
\hline & MEDIA+/- DE & 1358,0 & 1082,5 & 1113,0 \\
\hline & & 231,15 & 485,67 & 296,36 \\
\hline
\end{tabular}

Tabla 7. Mediciones realizadas en dos ocasiones diferentes por los tres observadores de las tres áreas seleccionadas (corte sagital, corte coronal y corte axial) del grupo III (hemimandíbula derecha: injerto con scaffold sembrado con células durante 21 días en medio de cultivo osteogénico). Media y desviación estándar (DE) de cada uno de las áreas de cada animal.

\begin{tabular}{|l|c|c|c|}
\cline { 2 - 4 } \multicolumn{1}{c|}{} & \multicolumn{3}{c|}{ GRUPO III } \\
\cline { 2 - 4 } \multicolumn{1}{c|}{} & AREA-1-DER & AREA-2-DER & AREA-3-DER \\
\hline MEDIA +/- DE & $1292 \pm 311$ & $919 \pm 315$ & $972 \pm 410$ \\
\hline MEDIANA (RANGO) & $1183(1017,5-1604,5)$ & $808(618-1234,5)$ & $830(627-1301)$ \\
\hline
\end{tabular}

Tabla 8. Medias y desviación estándar, medianas y rangos de valores obtenidos a partir de todas las mediciones realizadas por los tres observadores en los planos sagital (ÁREA-1-DER), coronal (ÁREA-2-DER) y axial (ÁREA-3-DER) de los animales pertenecientes al grupo III (hemimandíbula derecha de los animales 7 a 12 en los que rellenamos el defecto con scaffold cultivado en medio osteogénico con células durante 21 días). Estos son los valores que utilizaremos para llevar a cabo la comparación entre los diferentes grupos. 
RESULTADOS

\section{Resultados de las mediciones de las densidades medias de las áreas del grupo IV}

\begin{tabular}{|c|c|c|c|c|}
\hline \multirow[b]{2}{*}{ RATA } & \multirow[b]{2}{*}{ Observador } & \multicolumn{3}{|c|}{ GRUPO IV } \\
\hline & & AREA-1-IZQDA & AREA-2-IZQDA & AREA-3-IZQDA \\
\hline \multirow{8}{*}{7} & $\mathrm{~A}$ & 629 & 736 & 518 \\
\hline & $\mathrm{A}$ & 840 & 636 & 418 \\
\hline & $\mathrm{B}$ & 910 & 721 & 523 \\
\hline & $\mathrm{B}$ & 309 & 607 & 493 \\
\hline & $\mathrm{C}$ & 895 & 768 & 614 \\
\hline & $\mathrm{C}$ & 857 & 760 & 647 \\
\hline & MEDIA+/- DE & 739,9 & 704,7 & 535,6 \\
\hline & & 234,3 & 67,2 & 83,3 \\
\hline \multirow{8}{*}{9} & $\mathrm{~A}$ & 777 & 463 & 294 \\
\hline & $\mathrm{A}$ & 715 & 322 & 226 \\
\hline & $\mathrm{B}$ & 876 & 439 & 258 \\
\hline & $\mathrm{B}$ & 707 & 370 & 369 \\
\hline & $\mathrm{C}$ & 760 & 313 & 268 \\
\hline & $\mathrm{C}$ & 788 & 310 & 280 \\
\hline & MEDIA+/- DE & 770,5 & 369,5 & 282,5 \\
\hline & & 61,1 & 67,2 & 48,2 \\
\hline \multirow{8}{*}{10} & $\mathrm{~A}$ & 909 & 817 & 812 \\
\hline & $\mathrm{A}$ & 1094 & 642 & 665 \\
\hline & $\mathrm{B}$ & 944 & 494 & 454 \\
\hline & $\mathrm{B}$ & 1134 & 744 & 582 \\
\hline & $\mathrm{C}$ & 1242 & 735 & 941 \\
\hline & $\mathrm{C}$ & 1200 & 790 & 828 \\
\hline & MEDIA+/- DE & 1087,1 & 703,7 & 713,6 \\
\hline & & 135,0 & 118,9 & 179,7 \\
\hline \multirow{8}{*}{11} & $\mathrm{~A}$ & -65 & -78 & -26 \\
\hline & $\mathrm{A}$ & 100 & 58 & 23 \\
\hline & B & 295 & -200 & -349 \\
\hline & B & 256 & 284 & -356 \\
\hline & $\mathrm{C}$ & 225 & -41 & 191 \\
\hline & $\mathrm{C}$ & 243 & -28 & 53 \\
\hline & MEDIA+/- DE & 175,7 & 1,0 & $-77,4$ \\
\hline & & 135,1 & 162,8 & 225,0 \\
\hline \multirow{8}{*}{12} & $\mathrm{~A}$ & 488 & 314 & 315 \\
\hline & $\mathrm{A}$ & 589 & 427 & 604 \\
\hline & B & 426 & -56 & 123 \\
\hline & $\mathrm{B}$ & 258 & 600 & 796 \\
\hline & $\mathrm{C}$ & 651 & 128 & 429 \\
\hline & $\mathrm{C}$ & 819 & 810 & 490 \\
\hline & MEDIA+/- DE & 538,5 & 370,5 & 459,5 \\
\hline & & 343,09 & 384,89 & 628,6 \\
\hline
\end{tabular}

Tabla 9. Mediciones realizadas en dos ocasiones diferentes por los tres observadores de las tres áreas seleccionadas (corte sagital, corte coronal y corte axial) del grupo IV (hemimandíbula izquierda: injerto con scaffold sembrado con células durante 21 días en medio de cultivo no osteogénico). Media y desviación estándar (DE) de cada una de las áreas en cada animal.

\begin{tabular}{|l|c|c|c|}
\cline { 2 - 4 } \multicolumn{1}{c|}{} & \multicolumn{3}{c|}{ GRUPO IV } \\
\cline { 2 - 4 } \multicolumn{1}{c|}{} & AREA-1-IZQ & AREA-2-IZQ & AREA-3-IZQ \\
\hline MEDIA +/- DE & $662 \pm 335$ & $429 \pm 293$ & $383 \pm 300$ \\
\hline MEDIANA (RANGO) & $737,5(302-885)$ & $451(206-728)$ & $423,5(208,5-593)$ \\
\hline
\end{tabular}

Tabla 10. Medias y desviación estándar, medianas y rangos de valores obtenidos a partir de todas las mediciones realizadas por los tres observadores en los planos sagital (ÁREA-1-IZQ), coronal (ÁREA-2IZQ) y axial (ÁREA-3-IZQ) de los animales pertenecientes al grupo IV (hemimandíbula izquierda de animales $7,9,10,11$ y 12, en los que rellenamos el defecto creado con scaffold cultivado en medio no osteogénico con células durante 21 días). Estos son los valores que utilizaremos para llevar a cabo la comparación entre los diferentes grupos. 
Lo que hasta aquí tenemos es una recopilación de todos las mediciones realizadas, sus valores medios por área de estudio y la desviación estándar, así como las medianas y sus rangos. A partir de este momento, llevamos a cabo el análisis estadístico de estos datos.

Lo primero que vamos a hacer es analizar la variabilidad que existe entre los valores obtenidos a partir de las diferentes mediciones de densidad radiológica de cada una de las áreas. De este modo vamos a llevar a cabo un objetivo fundamental de este trabajo: analizar si podemos utilizar estos valores para el estudio estadístico y así comprobar la fiabilidad de nuestra metodología, en cuanto a la variabilidad y sobretodo reproductibilidad, a la hora de poder utilizar este método de evaluación de densidad radiológica en futuros estudios.

Para llevar a cabo este estudio vamos a comparar los coeficientes de variación $(\mathrm{CV} \%)$ de los valores obtenidos de todas las mediciones, lo que nos permitirá evaluar la variabilidad de los datos en ambos lados de la mandíbula de todos los animales en los 3 planos del espacio. Así podremos estudiar si existe mayor variabilidad entre los datos en función del corte específico (sagital, axial o coronal), del lado al que pertenece (izquierdo o derecho) o del grupo al que pertenece (I, II, III y IV).

A continuación mostramos una tabla (tabla 11) con los CV medios de cada medición realizada por cada observador en cada una de las áreas de cada animal, así como la media de los CV de todas las mediciones de cada área en cada hemimandíbula realizadas por los tres observadores. También mostramos una segunda tabla resumen de la anterior (tabla 12) en la que se muestra los CV medios de todas las mediciones realizadas en los once animales de experimentación en cada una de las áreas de cada hemimandíbula. 
RESULTADOS

\begin{tabular}{|c|c|c|c|c|c|c|c|}
\hline Rata & Observador & $\begin{array}{l}\text { AREA-1- } \\
\text { DER }\end{array}$ & $\begin{array}{c}\text { AREA-1- } \\
\text { IZQ }\end{array}$ & $\begin{array}{l}\text { AREA-2- } \\
\text { DER }\end{array}$ & $\begin{array}{c}\text { AREA-2- } \\
\text { IZQ }\end{array}$ & $\begin{array}{c}\text { AREA-3- } \\
\text { DER }\end{array}$ & $\begin{array}{c}\text { AREA-3- } \\
\text { IZQ } \\
\end{array}$ \\
\hline \multirow[t]{4}{*}{1} & A & 1,6 & 5,1 & 4,1 & 10,0 & 0,4 & 35,9 \\
\hline & $\mathrm{B}$ & 8,5 & 46,6 & 5,9 & 22,8 & 18,4 & 9,4 \\
\hline & $\mathrm{C}$ & 6,5 & 4,7 & 3,9 & 0,9 & 6,5 & 0,7 \\
\hline & MEDIA 1 & 5,5 & 18,8 & 4,6 & 11,2 & 8,4 & 15,3 \\
\hline \multirow[t]{4}{*}{2} & $\mathrm{~A}$ & 24,6 & 15,0 & 35,6 & 30,4 & 141,0 & 34,1 \\
\hline & $\mathrm{B}$ & 22,0 & 11,0 & 40,5 & 12,6 & 26,7 & 2,7 \\
\hline & $\mathrm{C}$ & 0,4 & 5,6 & 5,2 & 0,6 & 19,3 & 4,2 \\
\hline & MEDIA 2 & 15,7 & 10,5 & 27,1 & 14,5 & 62,3 & 13,7 \\
\hline \multirow[t]{4}{*}{3} & $\mathrm{~A}$ & 1,7 & 8,4 & 7,5 & 13,1 & 34,9 & 11,1 \\
\hline & $\mathrm{B}$ & 0,1 & 2,9 & 1,8 & 11,9 & 7,5 & 7,4 \\
\hline & $\mathrm{C}$ & 4,7 & 2,2 & 1,8 & 2,5 & 1,7 & 0,1 \\
\hline & MEDIA 3 & 2,1 & 4,5 & 3,7 & 9,2 & 14,7 & 6,2 \\
\hline \multirow[t]{4}{*}{4} & A & 15,9 & 2,8 & 23,9 & 21,5 & 78,9 & 58,6 \\
\hline & $\mathrm{B}$ & 2,7 & 31,1 & 3,5 & 3,9 & 69,1 & 47,7 \\
\hline & $\mathrm{C}$ & 0,6 & 3,7 & 1,2 & 0,6 & 6,5 & 10,1 \\
\hline & MEDIA 4 & 6,4 & 12,5 & 9,5 & 8,6 & 51,5 & 38,8 \\
\hline \multirow[t]{4}{*}{5} & A & 8,8 & 16,6 & 2,4 & 1,3 & 8,0 & 16,0 \\
\hline & $\mathrm{B}$ & 4,1 & 2,8 & 20,1 & 5,1 & 11,8 & 6,2 \\
\hline & $\mathrm{C}$ & 0,0 & 6,1 & 1,0 & 3,8 & 2,6 & 2,6 \\
\hline & MEDIA 5 & 4,3 & 8,5 & 7,9 & 3,4 & 7,5 & 8,3 \\
\hline \multirow[t]{4}{*}{6} & A & 4,71 & 16,5 & 11,37 & 7,39 & 5,89 & 7,11 \\
\hline & B & 5,6 & 8,5 & 18,6 & 10,8 & 12,9 & 8,2 \\
\hline & $\mathrm{C}$ & 6,6 & 7,0 & 15,3 & 7,6 & 13,7 & 16,1 \\
\hline & MEDIA 6 & 5,6 & 10,6 & 15,0 & 8,5 & 10,8 & 10,4 \\
\hline \multirow[t]{4}{*}{7} & A & 2,5 & 20,3 & 13,1 & 10,3 & 10,5 & 15,1 \\
\hline & $\mathrm{B}$ & 0,7 & 69,7 & 9,5 & 12,1 & 15,1 & 4,2 \\
\hline & $\mathrm{C}$ & 12,1 & 3,1 & 1,0 & 0,7 & 14,0 & 3,7 \\
\hline & MEDIA 7 & 5,1 & 31,0 & 7,8 & 7,7 & 13,2 & 7,7 \\
\hline \multirow[t]{4}{*}{9} & A & 5,6 & 5,9 & 52,3 & 25,4 & 28,9 & 18,5 \\
\hline & B & 0,8 & 15,1 & 31,6 & 12,1 & 22,3 & 25,0 \\
\hline & $\mathrm{C}$ & 1,7 & 2,5 & 9,8 & 0,7 & 18,1 & 3,1 \\
\hline & MEDIA 9 & 2,7 & 7,8 & 31,2 & 12,7 & 23,1 & 15,6 \\
\hline \multirow[t]{4}{*}{10} & A & 1,0 & 13,1 & 7,5 & 17,0 & 9,8 & 14,1 \\
\hline & B & 22,7 & 12,9 & 17,3 & 28,6 & 11,4 & 17,5 \\
\hline & $\mathrm{C}$ & 1,8 & 2,4 & 0,0 & 5,1 & 2,2 & 9,1 \\
\hline & MEDIA 10 & 8,5 & 9,5 & 8,3 & 16,9 & $\mathbf{7 , 8}$ & 13,5 \\
\hline \multirow[t]{4}{*}{11} & A & 4,9 & 139,7 & 20,9 & 139,4 & 31,4 & 135,9 \\
\hline & $\mathrm{B}$ & 12,6 & 10,0 & 5,5 & 140,8 & 17,2 & 110,0 \\
\hline & $\mathrm{C}$ & 1,1 & 5,3 & 0,6 & 122,6 & 7,3 & 80,3 \\
\hline & MEDIA 11 & 6,2 & 51,7 & 9,0 & 134,3 & 18,7 & 108,7 \\
\hline \multirow[t]{4}{*}{12} & A & 11,4 & 13,2 & 14,5 & 21,5 & 14,1 & 13,6 \\
\hline & B & 5,8 & 6,6 & 28,0 & 14,1 & 25,2 & 42 \\
\hline & $\mathrm{C}$ & 4,3 & 12,5 & 24,5 & 21,0 & 0,2 & 9,38 \\
\hline & MEDIA 12 & 7,1 & 10,7 & 22,3 & 18,8 & 13,1 & 21,7 \\
\hline
\end{tabular}

Tabla 11. Coeficientes de variación de las mediciones realizadas por cada observador en cada plano del espacio de cada hemimandíbula de todos los animales. Media de los coeficientes de variación de los valores obtenidos por los 3 observadores en cada área de estudio de los 11 animales. 


\begin{tabular}{|c|c|c|c|c|c|c|c|}
\hline & & AREA-1-DER & AREA-1-IZQ & AREA-2-DER & AREA-2-IZQ & AREA-3-DER & AREA-3-IZQ \\
\cline { 2 - 8 } & & 6,2 & 16,0 & 13,3 & 22,3 & 21,0 & 23,6 \\
\cline { 2 - 8 } & MEDIA 1-12 & 6,2 & 13,8 & 9,3 & 37,3 & 18,5 & 29,6 \\
\hline
\end{tabular}

Tabla 12. Media y desviación estándar (DE) de los coeficientes de variación medios de todos los animales en cada área de estudio de cada hemimandíbula.

A continuación mostramos, en la siguiente ilustración (tabla 13), los CV medios de las mediciones realizada por cada observador en cada área del espacio sin tener en cuenta si pertenece a la hemimandíbula izquierda o derecha, así como los valores medios de CV de las mediciones de los tres observadores en cada área de los once animales de experimentación. A continuación también mostramos una tabla resumen de la anterior (tabla 14) en la que aparecen los CV medios de todas las mediciones de todas las ratas en los tres planos del espacio. 


\begin{tabular}{|c|c|c|c|c|}
\hline Rata & Observador & AREA-1 & AREA-2 & AREA-3 \\
\hline \multirow[t]{4}{*}{1} & $\mathrm{~A}$ & 3,4 & 7,0 & 18,2 \\
\hline & $\mathrm{B}$ & 27,5 & 14,3 & 13,9 \\
\hline & $\mathrm{C}$ & 5,6 & 2,4 & 3,6 \\
\hline & MEDIA 1 & 12,2 & 7,9 & 11,9 \\
\hline \multirow[t]{4}{*}{2} & A & 19,8 & 33,0 & 87,6 \\
\hline & $\mathrm{B}$ & 16,5 & 26,5 & 14,7 \\
\hline & $\mathrm{C}$ & 3,0 & 2,9 & 11,7 \\
\hline & MEDIA 2 & 13,1 & 20,8 & 38,0 \\
\hline \multirow[t]{4}{*}{3} & $\mathrm{~A}$ & 5,1 & 10,3 & 23,0 \\
\hline & $\mathrm{B}$ & 1,5 & 6,9 & 7,4 \\
\hline & $\mathrm{C}$ & 3,4 & 2,2 & 0,9 \\
\hline & MEDIA 3 & 3,3 & 6,4 & 10,4 \\
\hline \multirow[t]{4}{*}{4} & $\mathrm{~A}$ & 9,3 & 22,7 & 68,7 \\
\hline & B & 16,9 & 3,7 & 58,4 \\
\hline & $\mathrm{C}$ & 2,2 & 0,9 & 8,3 \\
\hline & MEDIA 4 & 9,5 & 9,1 & 45,1 \\
\hline \multirow[t]{4}{*}{5} & A & 12,7 & 1,9 & 12,0 \\
\hline & $\mathrm{B}$ & 3,4 & 12,6 & 9,0 \\
\hline & $\mathrm{C}$ & 3,1 & 2,4 & 2,6 \\
\hline & MEDIA 5 & 6,4 & 5,6 & 7,9 \\
\hline \multirow[t]{4}{*}{6} & $\mathrm{~A}$ & 10,6 & 9,3 & 6,5 \\
\hline & $\mathrm{B}$ & 7,0 & 14,7 & 10,5 \\
\hline & $\mathrm{C}$ & 6,8 & 11,5 & 14,9 \\
\hline & MEDIA 6 & 8,1 & 11,8 & 10,6 \\
\hline \multirow[t]{4}{*}{7} & $\mathrm{~A}$ & 11,4 & 11,7 & 12,8 \\
\hline & $\mathrm{B}$ & 35,2 & 10,8 & 9,6 \\
\hline & $\mathrm{C}$ & 7,6 & 0,9 & 8,8 \\
\hline & MEDIA 7 & 18,1 & 7,8 & 10,4 \\
\hline \multirow[t]{4}{*}{9} & A & 5,8 & 38,9 & 23,7 \\
\hline & $\mathrm{B}$ & 7,9 & 21,8 & 23,7 \\
\hline & $\mathrm{C}$ & 2,1 & 5,3 & 10,6 \\
\hline & MEDIA 9 & 5,3 & 22,0 & 19,3 \\
\hline \multirow[t]{4}{*}{10} & $\mathrm{~A}$ & 7,0 & 12,2 & 12,0 \\
\hline & $\mathrm{B}$ & 17,8 & 22,9 & 14,4 \\
\hline & $\mathrm{C}$ & 2,1 & 2,6 & 5,6 \\
\hline & MEDIA 10 & 9,0 & 12,6 & 10,7 \\
\hline \multirow[t]{4}{*}{11} & $\mathrm{~A}$ & 72,3 & 80,2 & 83,6 \\
\hline & $\mathrm{B}$ & 11,3 & 73,2 & 63,6 \\
\hline & $\mathrm{C}$ & 3,2 & 61,6 & 43,8 \\
\hline & MEDIA 11 & 28,9 & 71,6 & 63,7 \\
\hline \multirow[t]{4}{*}{12} & A & 12,3 & 18,1 & 13,9 \\
\hline & B & 6,2 & 21,0 & 33,6 \\
\hline & C & 8,4 & 22,7 & 4,79 \\
\hline & MEDIA 12 & 8,9 & 20,6 & 17,43 \\
\hline
\end{tabular}

Tabla 13. Coeficientes de variación de los valores obtenidos por cada uno de los observadores en cada uno de los planos del espacio de todos los animales. Media de dichos coeficientes en cada área de estudio de cada animal.

\begin{tabular}{|c|c|c|c|c|}
\hline \multirow{3}{*}{ TOTAL } & & AREA-1 & AREA-2 & AREA-3 \\
\cline { 2 - 5 } & MEDIA 1-12 & 11,1 & 17,8 & 22,3 \\
\cline { 2 - 5 } & DE 1-12 & 7,1 & 18,8 & 18,3 \\
\hline
\end{tabular}

Tabla 14. Media y desviación estándar (DE) de los coeficientes de variación medios de cada área de estudio de los 11 animales. 
Una vez obtenidos todos estos valores, se procede a la evaluación estadística de los mismos con el programa SPSS. El objetivo fundamental es comparar los valores obtenidos de las áreas en cada uno de los cortes de los distintos grupos con las mismas áreas de cada corte de un grupo control, en este caso es el grupo II. De este modo cuantificamos la influencia de los distintos cultivos celulares sobre el scaffold frente al uso de scaffold sólo. Además comparamos las diferencias en la capacidad osteogénica de cada uno de los grupos comparando, en una segunda fase, todos los grupos entre sí: grupo I vs grupo III; grupo I vs grupo IV y grupo III $v s$ grupo IV.

Comparamos cada uno de los cortes de cada grupo a partir de los valores obtenidos del total de las mediciones realizadas en dos ocasiones por tres observadores, por lo que el tamño muestral para los grupos I y II es de $n=36$ y para los grupos III y IV es de $n=30$.

Por tanto, en esta primera fase del estudio se comparan cada uno de los grupos con el grupo control que es denominado grupo II (que corresponde con aquel defecto creado en las hemimandíbulas izquierdas de las ratas 1 a 6 y que se rellenó únicamente con el scaffold Meana). La variable de este estudio principal es la presencia de algún tipo de preparado celular en el injerto. Se compara el grupo I vs grupo II; grupo III vs grupo II y grupo IV vs grupo II (tablas 15-17). 


\section{GRUPO I vs GRUPO II}

\begin{tabular}{|c|c|c|c|c|c|}
\hline & \multicolumn{2}{|c|}{$\mathrm{MEDIAS} \pm \mathrm{DE}$} & \multicolumn{2}{|c|}{ MEDIANA (RANGO) } & \\
\hline Área & $\begin{array}{c}\text { GRUPO I } \\
(n=36)\end{array}$ & $\begin{array}{c}\text { GRUPO II } \\
(n=36)\end{array}$ & $\begin{array}{l}\text { GRUPO I } \\
(n=36)\end{array}$ & $\begin{array}{c}\text { GRUPO II } \\
(n=36)\end{array}$ & Sig. \\
\hline 1 & $1237 \pm 358$ & $1149 \pm 218$ & $1276,5(1000-1552)$ & $1142(942-1334,5)$ & NS \\
\hline 2 & $952 \pm 325$ & $1035 \pm 193$ & $964,5(744,5-1219)$ & $1012(838,5-1235)$ & NS \\
\hline 3 & $753 \pm 344$ & $650 \pm 313$ & $928(398-1086,5)$ & $636(384,5-877)$ & NS \\
\hline
\end{tabular}

Tabla 15. Comparativa de GRUPO CONTROL vs GRUPO I en los tres planos de estudio a través de las medias, DE, medianas y rangos a partir de las mediciones efectuadas por tres observadores diferentes en dos ocasiones.

En este caso no existen diferencias radiológicas significativas en los valores obtenidos entre el grupo I (scaffold con cultivo celular de un día en medio osteogénico) y el grupo II en ninguna de las áreas de los tres planos del espacio. Por tanto no existen diferencias significativas en las densidades radiológicas en los defectos rellenados con el scaffold sólo y aquellos defectos rellenados con scaffold y células cultivadas durante un solo día (tabla 15).

\section{GRUPO II vs GRUPO III}

\begin{tabular}{|c|c|c|c|c|c|}
\cline { 2 - 6 } \multicolumn{1}{c|}{} & \multicolumn{2}{c|}{ MEDIAS \pm DE } & \multicolumn{2}{c|}{ MEDIANA (RANGO) } & \\
\hline Área & $\begin{array}{c}\text { GRUPO II } \\
(\mathbf{n = 3 6 )}\end{array}$ & $\begin{array}{c}\text { GRUPO III } \\
(\mathbf{n = 3 0})\end{array}$ & $\begin{array}{c}\text { GRUPO II } \\
(\mathbf{n = 3 6 )}\end{array}$ & $\begin{array}{c}\text { GRUPO III } \\
(\mathbf{n = 3 0})\end{array}$ & Sig. \\
\hline 1 & $1149 \pm 218$ & $1292 \pm 311$ & $1142(942-1334,5)$ & $1183(1017,5-1604,5)$ & NS \\
\hline 2 & $1035 \pm 193$ & $919 \pm 315$ & $1012(838,5-1235)$ & $808(618-1234,5)$ & NS \\
\hline 3 & $650 \pm 313$ & $972 \pm 410$ & $636(384,5-877)$ & $830(627-1301)$ & 0,03 \\
\hline
\end{tabular}

Tabla 16. Comparativa de GRUPO CONTROL vs GRUPO III, en los tres planos del espacio a través de las medias, DE, medianas y rangos a partir de las mediciones efectuadas por tres observadores diferentes en dos ocasiones.

En este caso tampoco existen diferencias significativas entre los grupos II y III, excepto en el área 3 que corresponde al área del plano axial en que observamos una mayor densidad radiológica en el grupo III respecto al II, siendo ésta estadísticamente 
significativa $(\mathrm{p}=0,03)$. Al poder observar diferencia en uno solo de los cortes, y en los otros dos cortes no existir siquiera cierta tendencia, no podemos concluir diferencias entre el grupo control y el grupo III (aquel en el que el defecto óseo se rellenó con el scaffold Meana y células diferenciadas en medio de cultivo osteogénico durante tres semanas) (tabla 16).

\section{GRUPO II vs GRUPO IV}

\begin{tabular}{|c|c|c|c|c|c|}
\cline { 2 - 5 } \multicolumn{1}{c|}{} & \multicolumn{2}{c|}{ MEDIAS \pm DE } & \multicolumn{2}{c|}{ MEDIANA (RANGO) } & \multicolumn{1}{c|}{} \\
\hline Área & $\begin{array}{c}\text { GRUPO II } \\
(\mathbf{n}=\mathbf{3 6})\end{array}$ & $\begin{array}{c}\text { GRUPO IV } \\
(\mathbf{n = 3 0})\end{array}$ & $\begin{array}{c}\text { GRUPO II } \\
(\mathbf{n = 3 6})\end{array}$ & $\begin{array}{c}\text { GRUPO IV } \\
(\mathbf{n = 3 0})\end{array}$ & Sig. \\
\hline 1 & $1149 \pm 218$ & $662 \pm 335$ & $1142(942-1334,5)$ & $737,5(302-885)$ & $<0,001$ \\
\hline 2 & $1035 \pm 193$ & $429 \pm 293$ & $1012(838,5-1235)$ & $451(206-728)$ & $<0,001$ \\
\hline 3 & $650 \pm 313$ & $383 \pm 300$ & $636(384,5-877)$ & $423,5(208,5-593)$ & 0,023 \\
\hline
\end{tabular}

Tabla 17. Comparativa de GRUPO CONGROL vs GRUPO IV en los tres planos del espacio a través de las medias, DE, medianas y rangos a partir de las mediciones efectuadas por tres observadores diferentes en dos ocasiones.

En este caso existe una mayor densidad radiológica en el grupo control (scaffold Meana solamente) respecto al grupo IV (aquel defecto óseo rellenado con scaffold Meana y células cultivadas en medio no osteogénico durante tres semanas) en los tres planos del espacio, observando diferencias estadísticamente significativas en el plano sagital $(p<0,01)$, en el plano coronal $(p<0,01)$ y en el plano axial $(p=0,023)($ tabla 17$)$.

Para evaluar los resultados regenerativos de cada uno de los grupos, y ver las diferencias que pueden existir entre las distintas matrices procedemos a realizar, de igual modo, el análisis estadístico comparando el resto de los grupos: grupo I vs grupo III; grupo I vs grupo IV y grupo III vs grupo IV (tablas 18-20). 


\section{GRUPO I vs III}

\begin{tabular}{|c|c|c|c|c|c|}
\cline { 2 - 6 } \multicolumn{1}{c|}{} & \multicolumn{2}{c|}{ MEDIAS \pm DE } & \multicolumn{2}{c|}{ MEDIANA (RANGO) } & \\
\hline Área & $\begin{array}{c}\text { GRUPO I } \\
(\mathbf{n = 3 6 )}\end{array}$ & $\begin{array}{c}\text { GRUPO III } \\
(\mathbf{n}=\mathbf{3 0})\end{array}$ & $\begin{array}{c}\text { GRUPO I } \\
(\mathbf{n = 3 6 )}\end{array}$ & $\begin{array}{c}\text { GRUPO III } \\
(\mathbf{n}=\mathbf{3 0})\end{array}$ & Sig. \\
\hline 1 & $1237 \pm 358$ & $1292 \pm 311$ & $1276,5(1000-1552)$ & $1183(1017,5-1604,5)$ & NS \\
\hline 2 & $952 \pm 325$ & $919 \pm 315$ & $964,5(744,5-1219)$ & $808(618-1234,5)$ & NS \\
\hline 3 & $753 \pm 344$ & $972 \pm 410$ & $928(398-1086,5)$ & $830(627-1301)$ & NS \\
\hline
\end{tabular}

Tabla 18. Comparativa de GRUPO I vs GRUPO III en las tres áreas de estudio a través de las medias, DE, medianas y rangos a partir de las mediciones efectuadas por tres observadores diferentes en dos ocasiones.

En este caso no existen diferencias estadísticamente significativas entre los grupos I y III, es decir no existe una diferencia de densidad radiológica en los grupos con injertos con scaffold y células cultivadas un día en medio osteogénico y aquellos grupos en los que se injertaron scaffold con células cultivadas 21 días en medio osteogénico (tabla 18).

\section{GRUPO I vs GRUPO IV}

\begin{tabular}{|c|c|c|c|c|c|}
\hline & \multicolumn{2}{|c|}{$\mathrm{MEDIAS} \pm \mathrm{DE}$} & \multicolumn{2}{|c|}{ MEDIANA (RANGO) } & \\
\hline Área & $\begin{array}{c}\text { GRUPO I } \\
(n=36)\end{array}$ & $\begin{array}{c}\text { GRUPO IV } \\
(n=30)\end{array}$ & $\begin{array}{l}\text { GRUPO I } \\
(\mathrm{n}=36)\end{array}$ & $\begin{array}{l}\text { GRUPO IV } \\
\begin{array}{c}(n=30) \\
\text { (n) }\end{array}\end{array}$ & Sig. \\
\hline 1 & $1237 \pm 358$ & $662 \pm 335$ & $1276,5(1000-1552)$ & $737,5(302-885)$ & $<0,001$ \\
\hline 2 & $952 \pm 325$ & $429 \pm 293$ & $964,5(744,5-1219)$ & 451 (206-728) & $<0,001$ \\
\hline 3 & $753 \pm 344$ & $383 \pm 300$ & $928(398-1086,5)$ & $423,5(208,5-593)$ & 0,005 \\
\hline
\end{tabular}

Tabla 19. Comparativa de GRUPO I vs GRUPO IV en las tres áreas de estudio a través de las medias, DE, medianas y rangos a partir de las mediciones efectuadas por tres observadores diferentes en dos ocasiones.

Observamos diferencias significativas a favor del grupo I tanto en el área 1 o sagital $(\mathrm{p}<0,001)$, en el área 2 o plano coronal $(\mathrm{p}<0,001)$ como en el plano axial o área 3 $(\mathrm{p}=0,005)$. Estos datos nos permiten afirmar que existe un aumento de densidad radiológica en los grupos en los que se injertaron scaffold sólo respecto aquellos en los 
que se injertaron scaffold con cultivo celular durante 21 días en medio no osteogénico (tabla 19).

GRUPO III vs GRUPO IV

\begin{tabular}{|c|c|c|c|c|l|}
\cline { 2 - 5 } \multicolumn{1}{c|}{} & \multicolumn{2}{c|}{ MEDIAS \pm DE } & \multicolumn{2}{c|}{ MEDIANA (RANGO) } & \multicolumn{1}{|l|}{} \\
\hline Área & $\begin{array}{c}\text { GRUPO III } \\
(\mathbf{n}=\mathbf{3 0})\end{array}$ & $\begin{array}{c}\text { GRUPO IV } \\
(\mathbf{n}=\mathbf{3 0})\end{array}$ & $\begin{array}{c}\text { GRUPO III } \\
(\mathbf{n}=\mathbf{3 0})\end{array}$ & $\begin{array}{c}\text { GRUPO IV } \\
(\mathbf{n}=\mathbf{3 0})\end{array}$ & \multirow{2}{*}{ Sig. } \\
\hline 1 & $1292 \pm 311$ & $662 \pm 335$ & $1183(1017,5-1604,5)$ & $737,5(302-885)$ & $<0,001$ \\
\hline 2 & $919 \pm 315$ & $429 \pm 293$ & $808(618-1234,5)$ & $451(206-728)$ & $<0,001$ \\
\hline 3 & $972 \pm 410$ & $383 \pm 300$ & $830(627-1301)$ & $423,5(208,5-593)$ & $<0,001$ \\
\hline
\end{tabular}

Tabla 20. Comparativa de grupo III vs GRUPO IV en las tres áreas de estudio a través de las medias, DE, medianas y rangos a partir de las mediciones efectuadas por tres observadores diferentes en dos ocasiones.

Volvemos a encontrar una menor densidad radiológica estadísticamente significativa en el grupo IV con una $\mathrm{p}<0,001$ en las tres áreas, en este caso frente al grupo III. Es decir los defectos rellenados con scaffold con células cultivadas en medio osteogénico durante 21 días presentan unos valores de densidad radiológica mayor que aquellos defectos rellenados con scaffold con cultivo celular de 21 días sin diferenciar (tabla 20).

A continuación mostramos (ilustraciones 61 a 66), para tener una visión más intuitiva de las diferencias entre los grupos I, III y IV con el grupo control, así como de los distintos grupos entre sí, los diagramas de barras de error y diagramas de barras ilustrando los valores presentados en las tablas anteriores (tablas 15-20). 


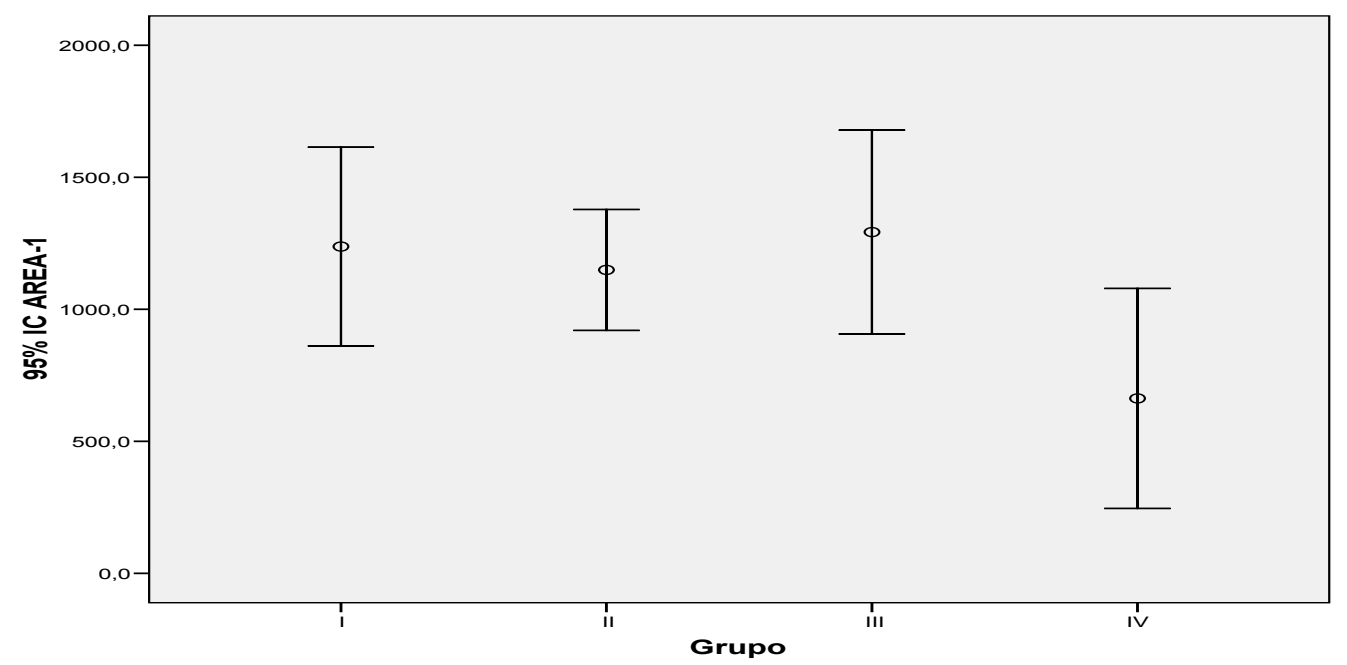

Ilustración 61. Diagrama de barras de error que refleja la distribución de los valores de cada uno de los grupos en el área 1 correspondiente al plano sagital. Se observa que el grupo IV (scaffold con células cultivadas durante 21 días en medio no osteogénico) es el que menor valor de densidad radiológica presenta.

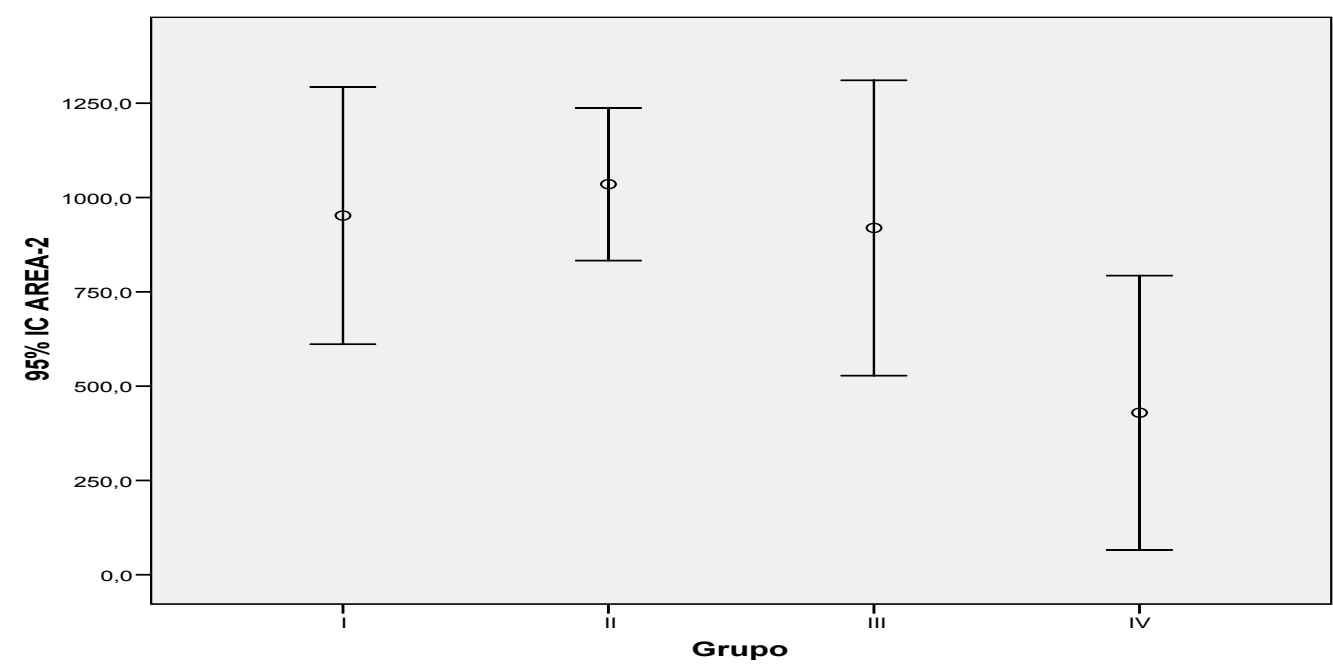

Ilustración 62. Diagrama de barras de error que refleja la distribución de los valores de cada uno de los grupos en el área 2 correspondiente al plano coronal. Se observa que el grupo IV (scaffold con células cultivadas durante 21 días en medio no osteogénico) es el que menor valor de densidad radiológica presenta. 


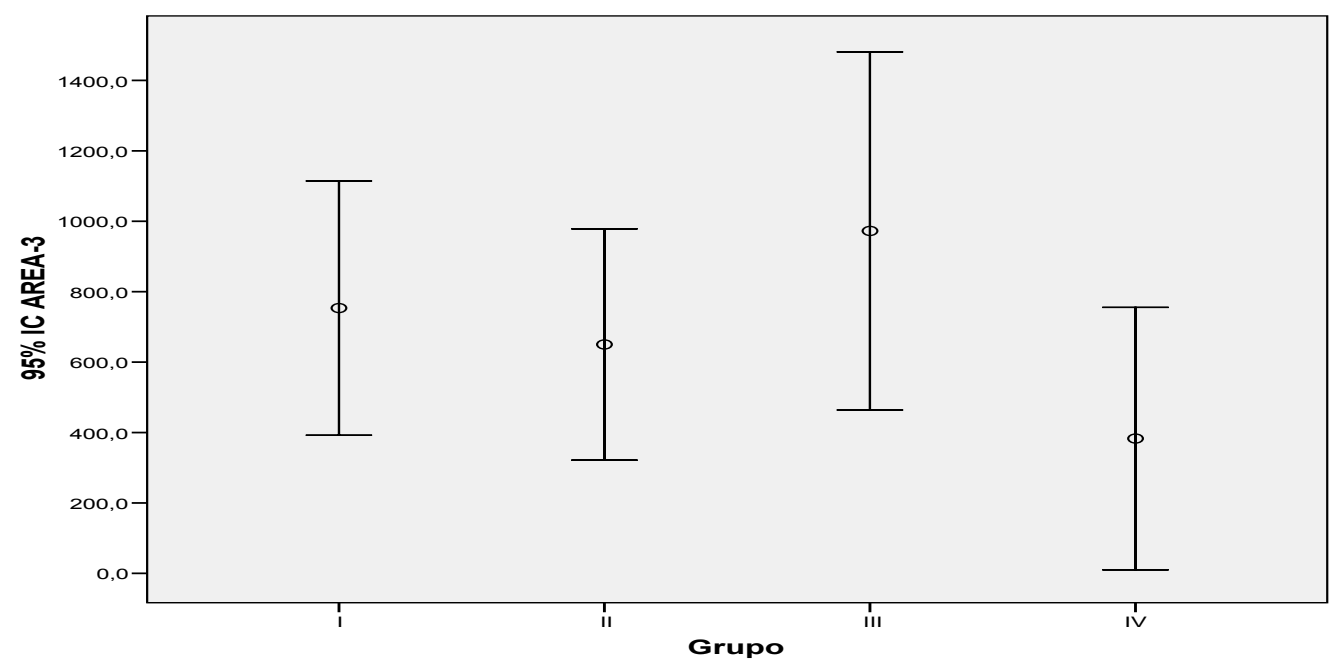

Ilustración 63. Diagrama de barras de error que refleja la distribución de los valores de cada uno de los grupos en el área 3 correspondiente al plano axial. Se observa que el grupo IV (scaffold con células cultivadas durante 21 días en medio no osteogénico) es el que menor valor de densidad radiológica presenta , aunque en menor diferencia que en las anteriores áreas.

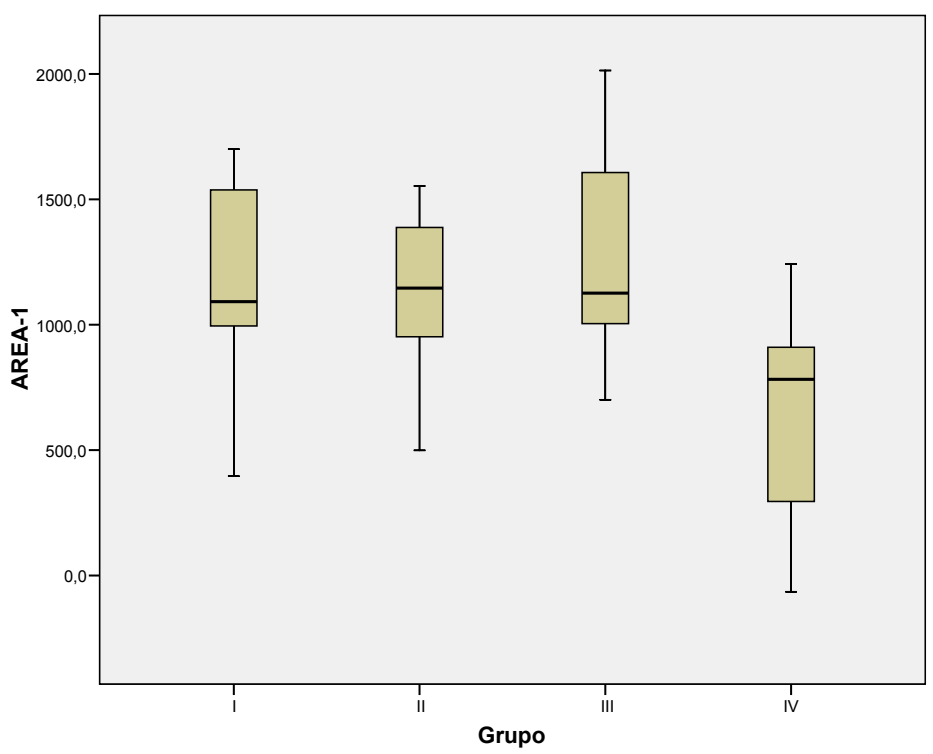

Ilustración 64. Diagrama de barras que refleja la distribución de las medianas y rangos de cada uno de los grupos correspondientes al área 1 (plano sagital). Se aprecia una leve diferencia entre los 3 primeros grupos, no así en el grupo IV (scaffold con cultivo celular en medio no ostegénico durante 21 días) en el que observamos menor valor de densidad raiológica. 


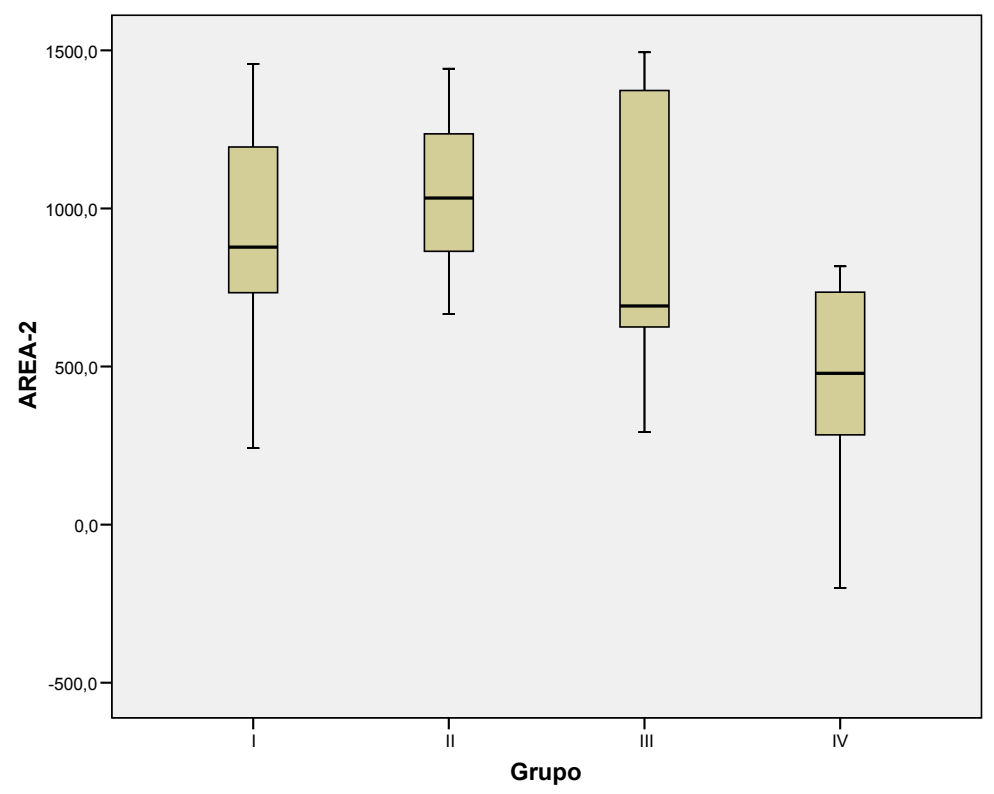

Ilustración 65. Diagrama de barras que refleja la distribución de las medianas y rangos de cada uno de los grupos correspondientes al área 2 (plano coronal). Se aprecia una leve diferencia entre los 3 primeros grupos, no así en el grupo IV (scaffold con cultivo celular en medio no ostegénico durante 21 días) en el que vemos menor valor de densidad raiológica.

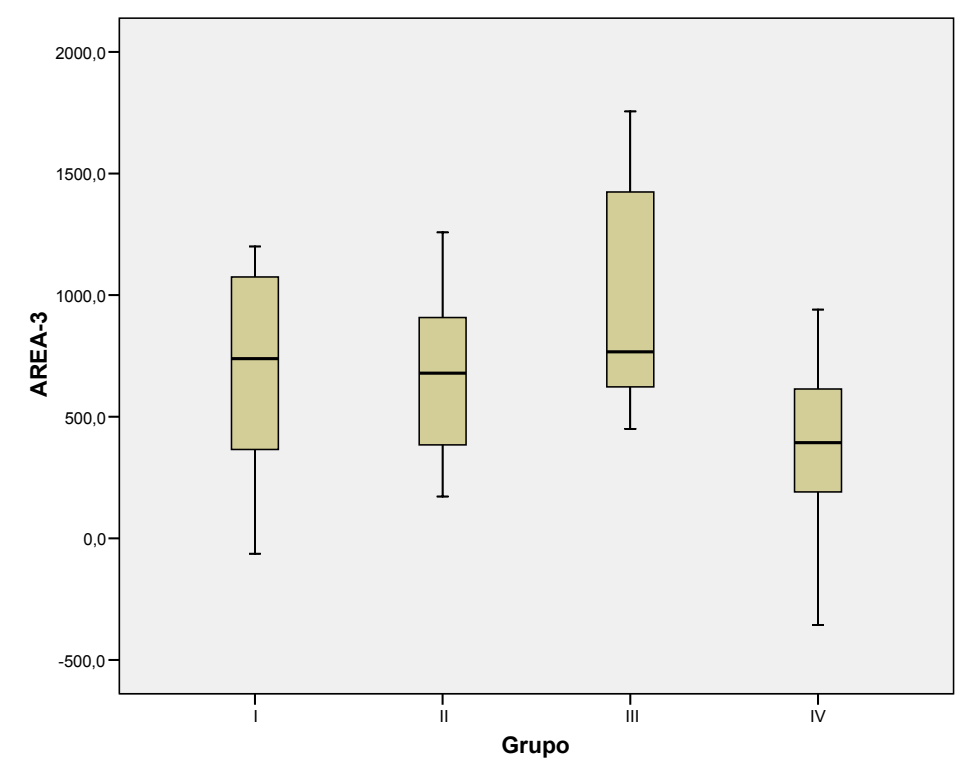

Ilustración 66. Diagrama de barras que refleja la distribución de las medianas y rangos de cada uno de los grupos correspondientes al área 3 (plano axial). Se aprecia una leve diferencia entre los 3 primeros grupos, no así en el grupo IV (scaffold con cultivo celular en medio no ostegénico durante 21 días)en el que vemos menor valor de densidad raiológica, sin ser ésta tan acusada como en las otras áreas.

Como resumen de todo lo anterior, podemos afirmar que no existen diferencias significativas en cuanto a la densidad radiológica en los grupos I, II y III. Sin embargo, en todos los casos existe un claro aumento de densidad radiológica en los grupos I, II y III respecto al grupo IV. 


\subsection{RESULTADOS HISTOLOGICOS}

\subsubsection{VALORACIÓN MACROSCÓPICA}

Se llevó a cabo una valoración del aspecto general de la muestra durante el propio acto de disección, atendiendo a distintos parámetros descriptivos como es la organización anatómica de los tejidos, la forma y consistencia del defecto, presencia de infección o exudados, presencia de fracturas o secuestros óseos, desplazamiento de la matriz fuera del defecto o alteraciones dentarias asociadas.

En todos los casos se observan restos de matriz dentro del defecto, sin que exista desplazamiento de la matriz. Una consistencia semirrígida en la zona del defecto bien localizado y fácilmente identificable, sin que exista presencia de procesos infecciosos o supurativos asociados. Se observa ausencia de daños en dientes cercanos a la implantación así como ausencia de fracturas en hueso vecino a la lesión, existiendo en todos los casos integridad del contorno óseo circundante al defecto (ilustración 67 y 68). Por tanto, en la valoración macroscópica, realizada no se observan diferencias en el aspecto general de la zona del defecto independientemente del grupo al que pertenezca.

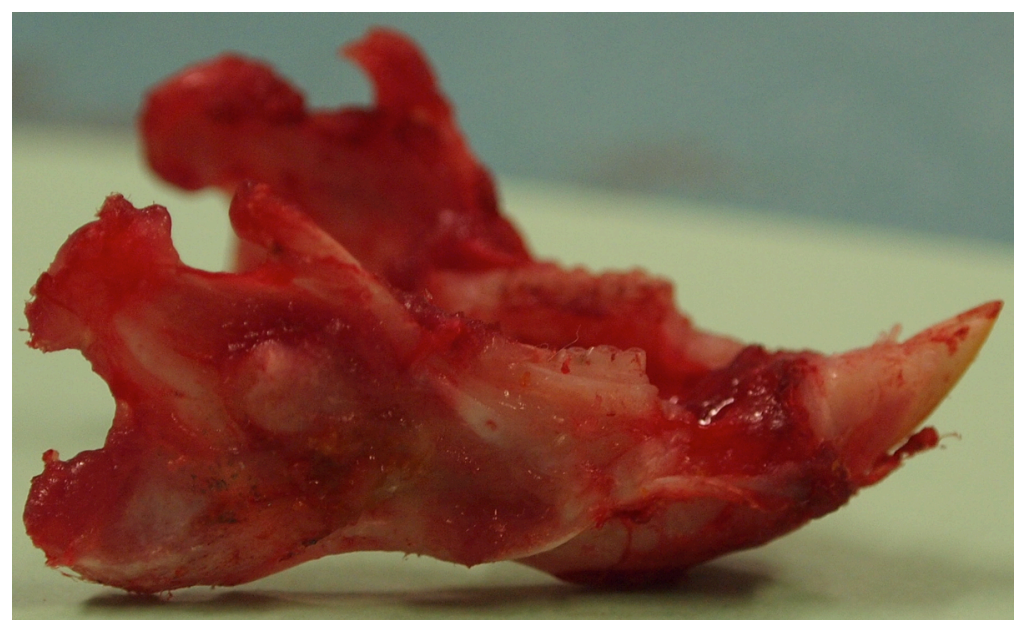

Ilustración 67. Mandíbula diseccionada para posterior estudio radiológico e histológico, en el que apreciamos la zona del defecto. 


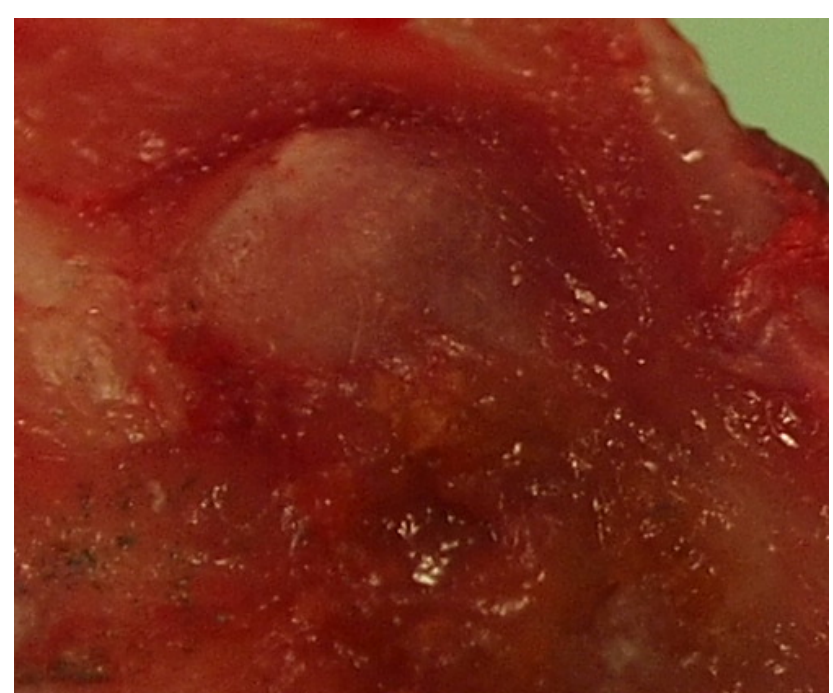

Ilustración 68. Detalle de la imagen anterior en la que vemos a gran aumento el aspecto general del defecto.

\subsubsection{VALORACIÓN MICROSCÓPICA}

El estudio histológico descriptivo de las diferentes muestras corroboran los resultados radiológicos, en los que no se aprecian diferencias significativas en los grupos I, II y III en cuanto a la presencia de células óseas, restos de scaffold o madurez del tejido formado. Sin embargo existe una clara diferencia con las muestras del grupo IV, en las que apenas se observan células óseas ni tejido óseo neoformado y sí abundantes restos del scaffold.

A continuación mostramos cortes histológicos con tinción de H-E de una muestra representativa de cada uno de los grupos (ilustración 69-83). 


\section{GRUPO I: scaffold con células sembradas en medio osteogénico durante 24 horas.}

\section{Hemimandíbula derecha del espécimen $n^{0} 5$.}

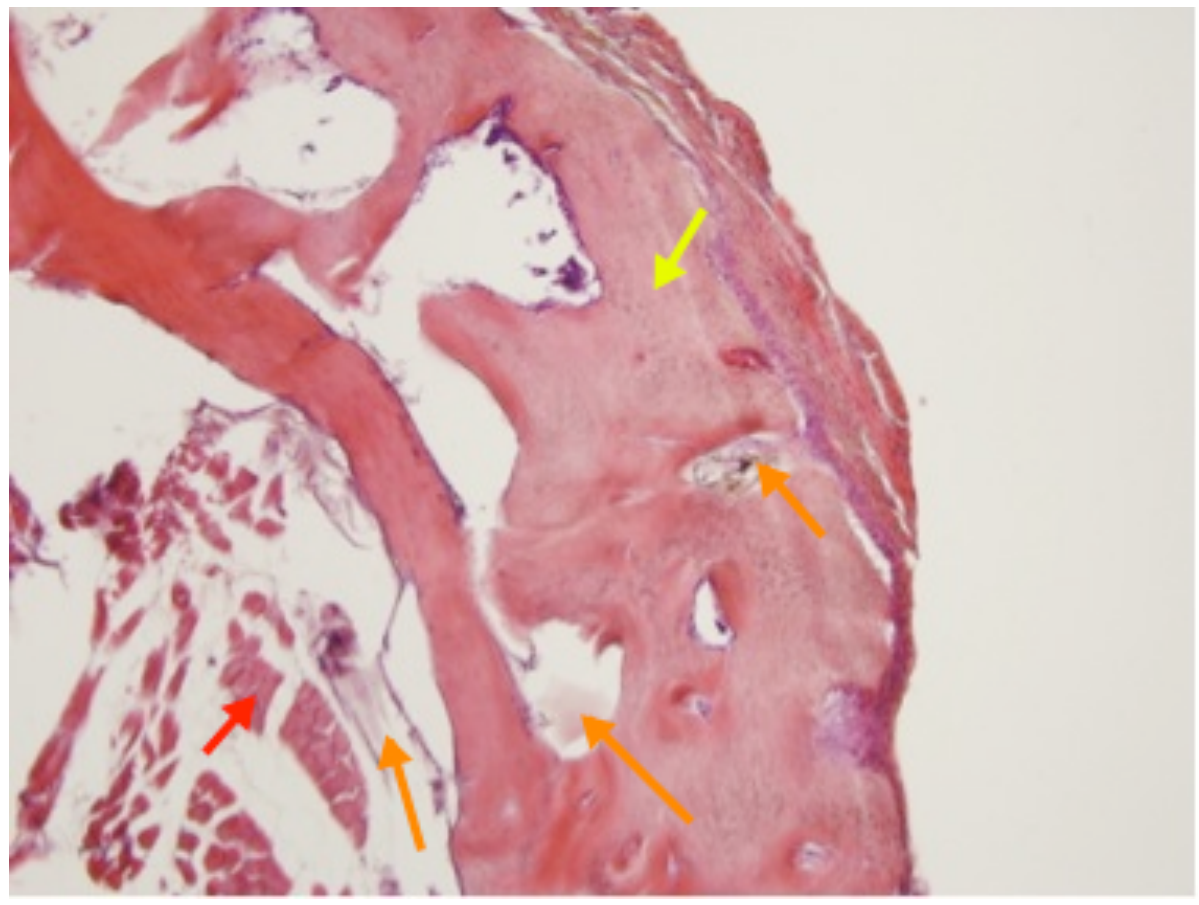

Ilustración 69. Imagen obtenida con microscopio de luz a 40 aumentos de corte de mandíbula de rata de grupo I teñido con H-E. Observamos neoformación ósea $(\rightarrow)$ y restos de scaffold $(\rightarrow)$ intercalado adyacente a músculo esquelético $(\rightarrow)$.

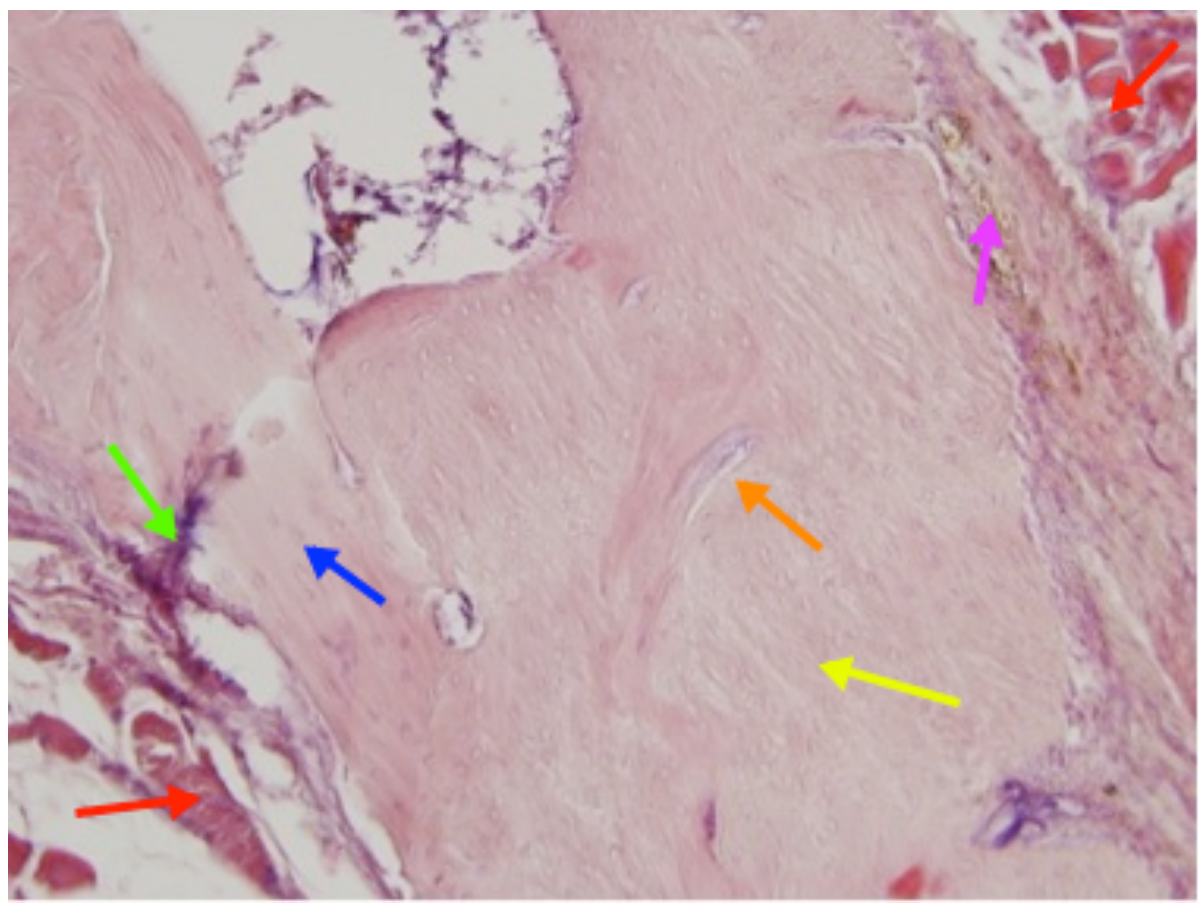

Ilustración 70. Imagen obtenida con microscopio de luz a 100 aumentos de corte de mandíbula de rata de grupo I teñido con H-E donde observamos tejido osteoide neoformado $(\rightarrow$ ) con restos de scaffold incluidos $(\rightarrow)$. Se aprecian también lagunas en el hueso neoformado con osteocitos $(\rightarrow)$. El tejido óseo se encuentra separado del músculo esquelético $(\rightarrow)$ por formación de periostio $(\rightarrow)$, que se observa con coloración más intensa. Aparecen restos de hemosiderina de color marrón $(\rightarrow)$. 


\section{RESULTADOS}

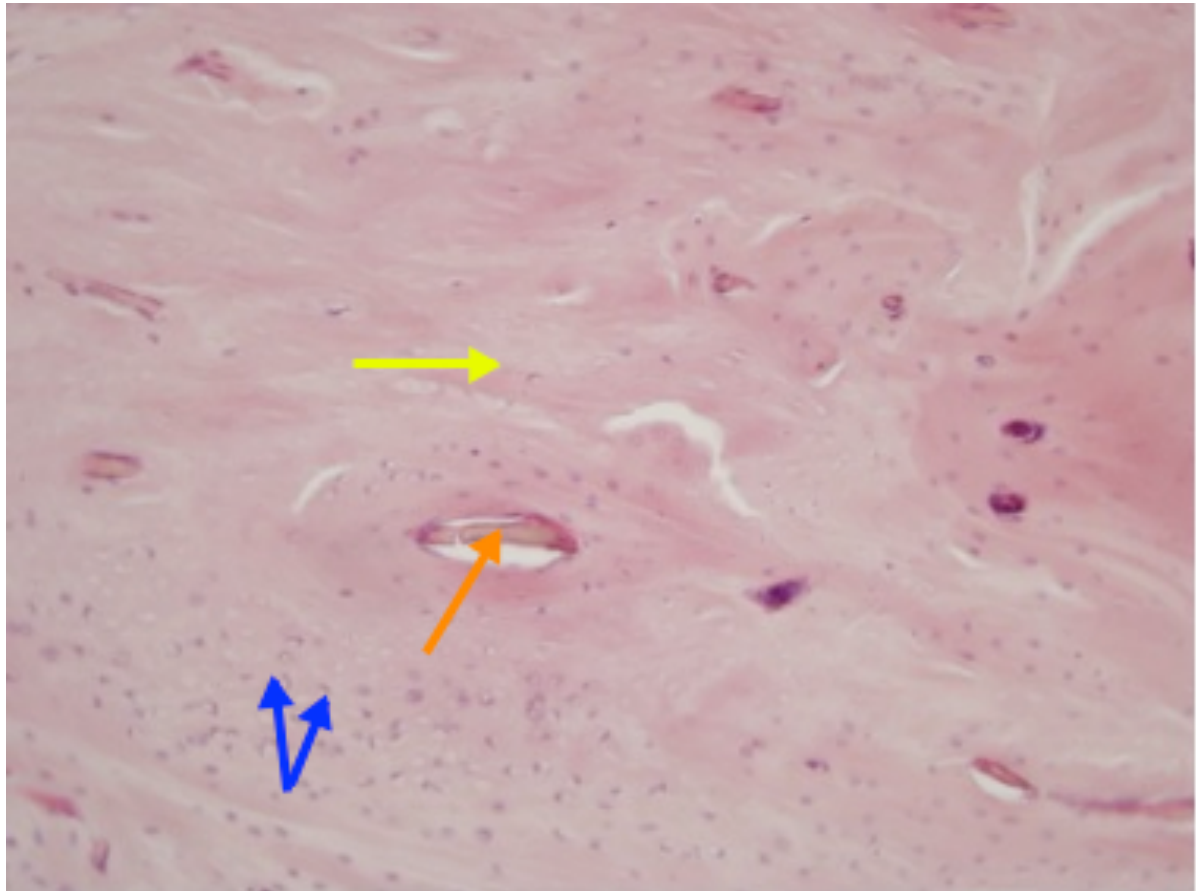

Ilustración 71. Imagen obtenida con microscopio de luz a 200 aumentos de corte de mandíbula de rata de grupo I teñido con H-E donde observamos el tejido osteoide organizado $(\rightarrow)$ y lagunas en su interior con esa coloración azulada característica del núcleo del osteocito $(\rightarrow)$. Aparecen restos de scaffold $(\rightarrow)$.

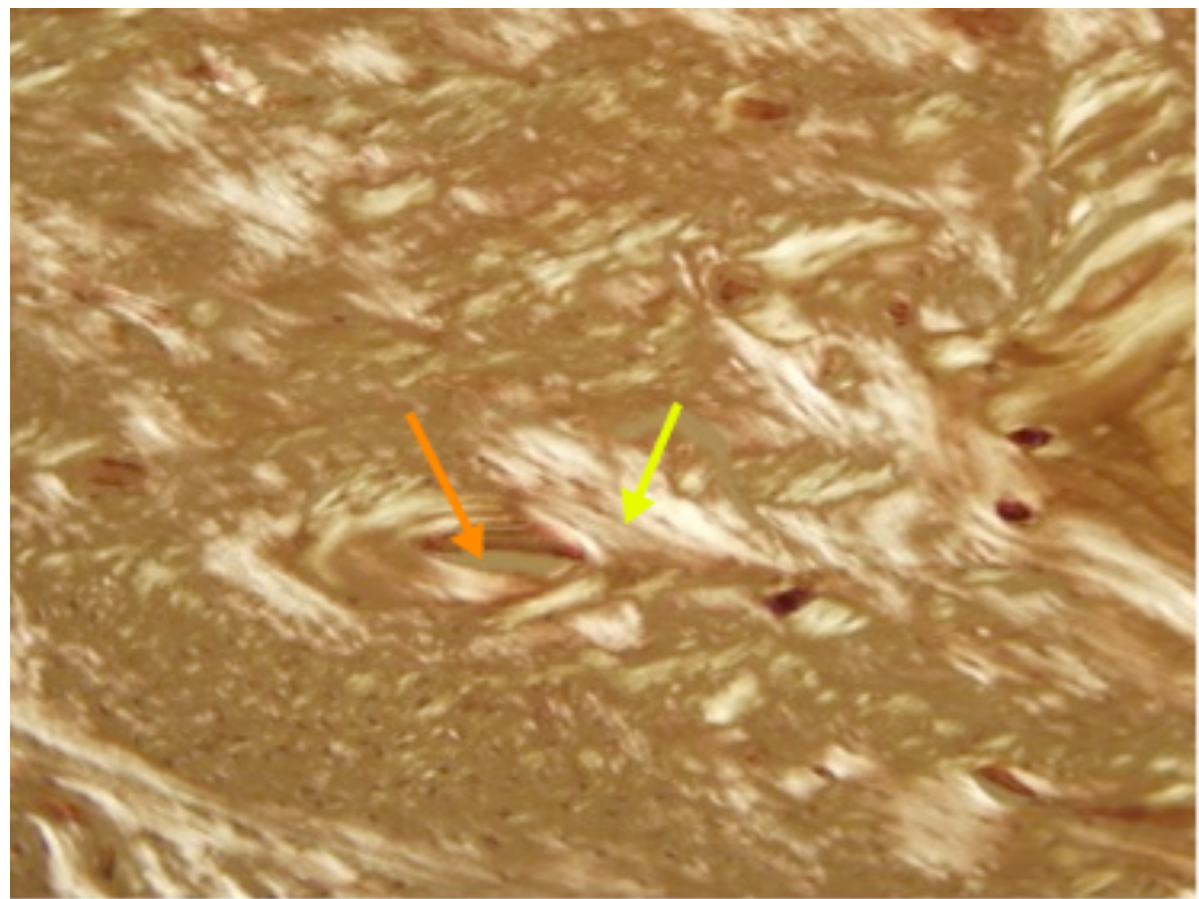

Ilustración 72. Misma imagen que la anterior obtenida a 200 aumentos visualizada con luz polarizada. Apreciamos la refringencia característica de un tejido entrecruzado osteoide algo inmaduro $(\rightarrow)$ en relación a resto de scaffold $(\rightarrow)$. 


\section{GRUPO II: CONTROL: con scaffold solamente. Hemimandíbula izquierda del}

\section{espécimen $\mathbf{n}^{0} 1$}

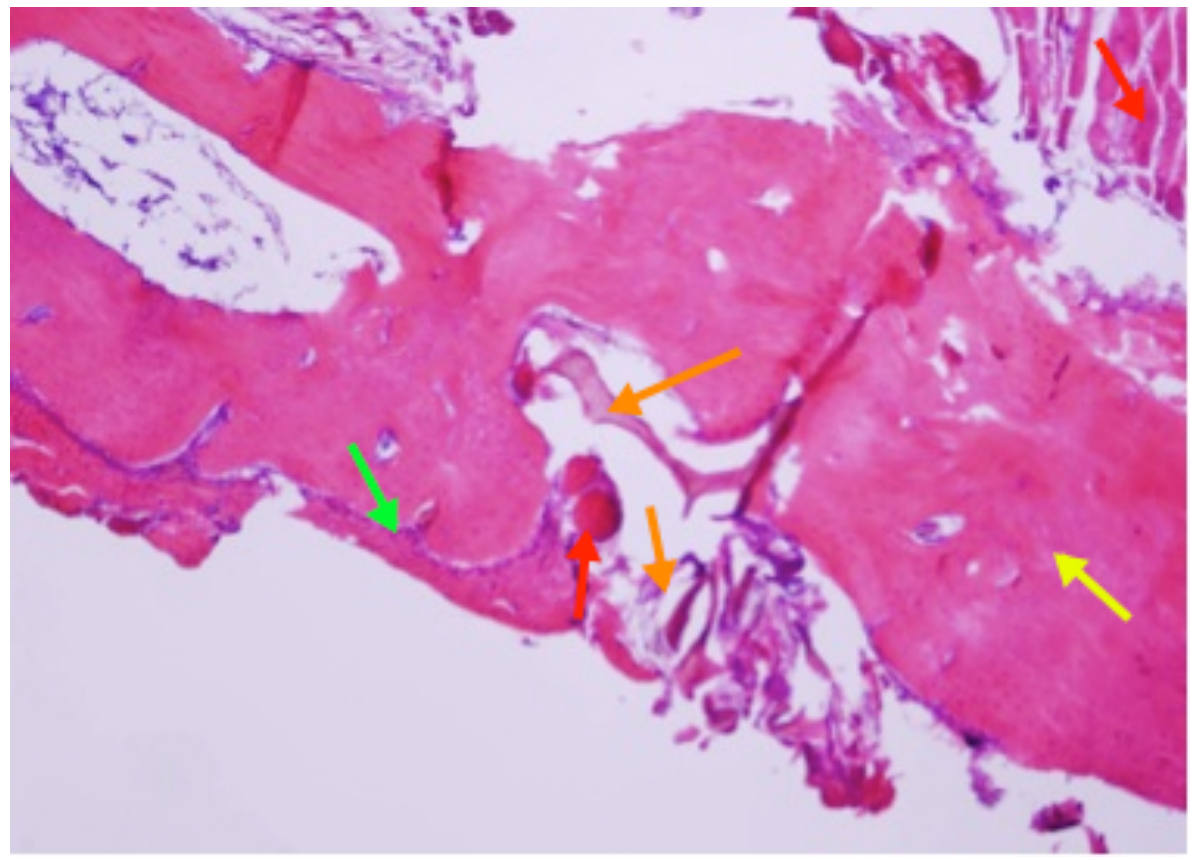

Ilustración 73. Imagen obtenida con microscopio de luz a 40 aumentos de corte de mandíbula de rata de grupo II teñido con H-E donde se observan restos de scaffold $(\rightarrow$ y tejido óseo $(\rightarrow$ ). Se aprecia una coloración más intensa del periostio $(\rightarrow)$ y músculo esquelético $(\rightarrow$ ) en la proximidad del scaffold.

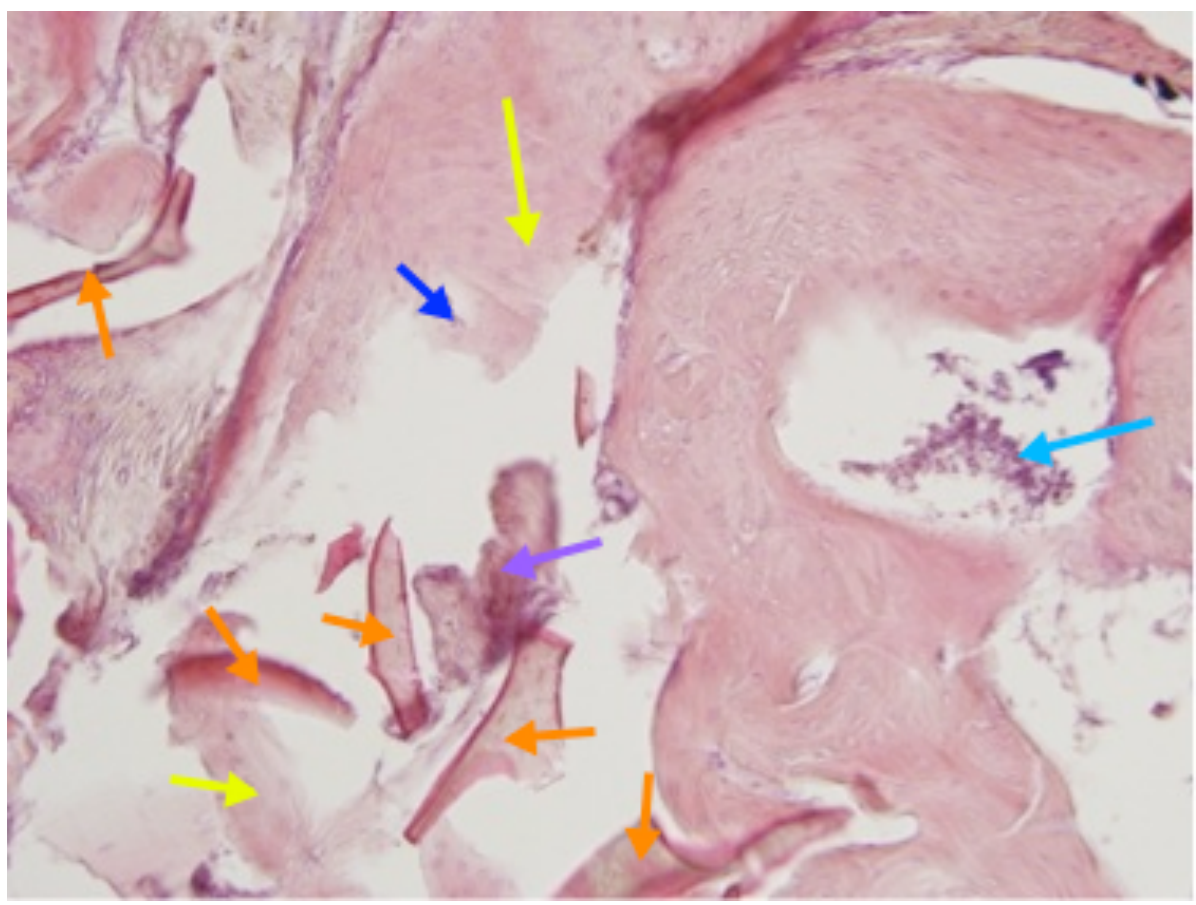

Ilustración 74. Imagen obtenida con microscopio de luz a 100 aumentos de corte de mandíbula de rata de grupo II teñido con H-E. Se observa hueso $(\longrightarrow)$ y hueso neoformado $(\rightarrow)$ alrededor de restos de scaffold $(\rightarrow)$ con una característica coloración azul de los núcleos de los osteocitos $(\rightarrow)$. Se observa también depósito de tejido granular y basófilo sugestivo de depósito de calcio $(\rightarrow)$. 


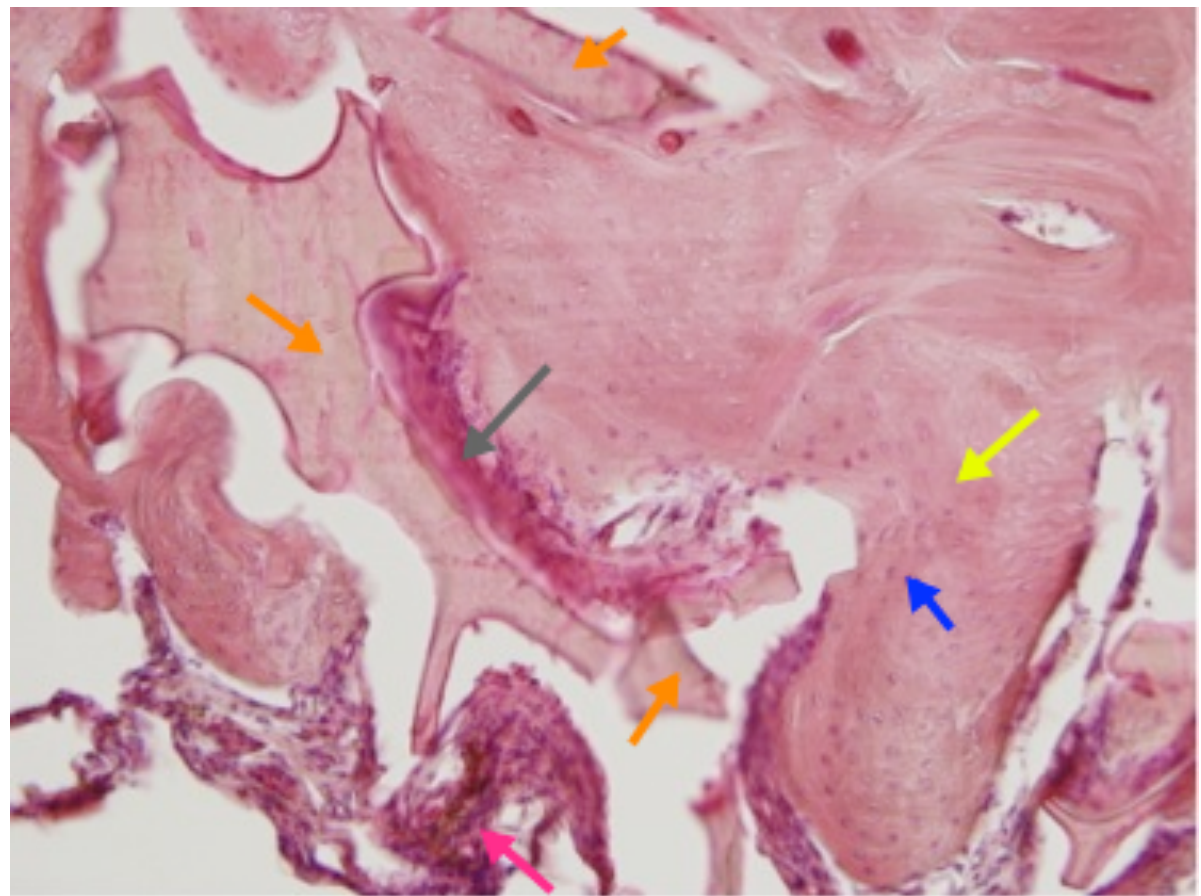

Ilustración 75 . Imagen obtenida con microscopio de luz a 100 aumentos de corte de mandíbula de rata de grupo II teñido con H-E donde apreciamos zonas de tejido conectivo laxo $(\rightarrow)$ en contacto con restos de scaffold $(\rightarrow)$ en fase previa a la calcificación. Lagunas con núcleos de osteocitos con la coloración azul característica $(\rightarrow$ ) en zonas de matriz ósea $(\rightarrow$ ). Se aprecia una zona de color más marrón de restos de depósito de hemosiderina $(\rightarrow$ ) por la herida quirúrgica.

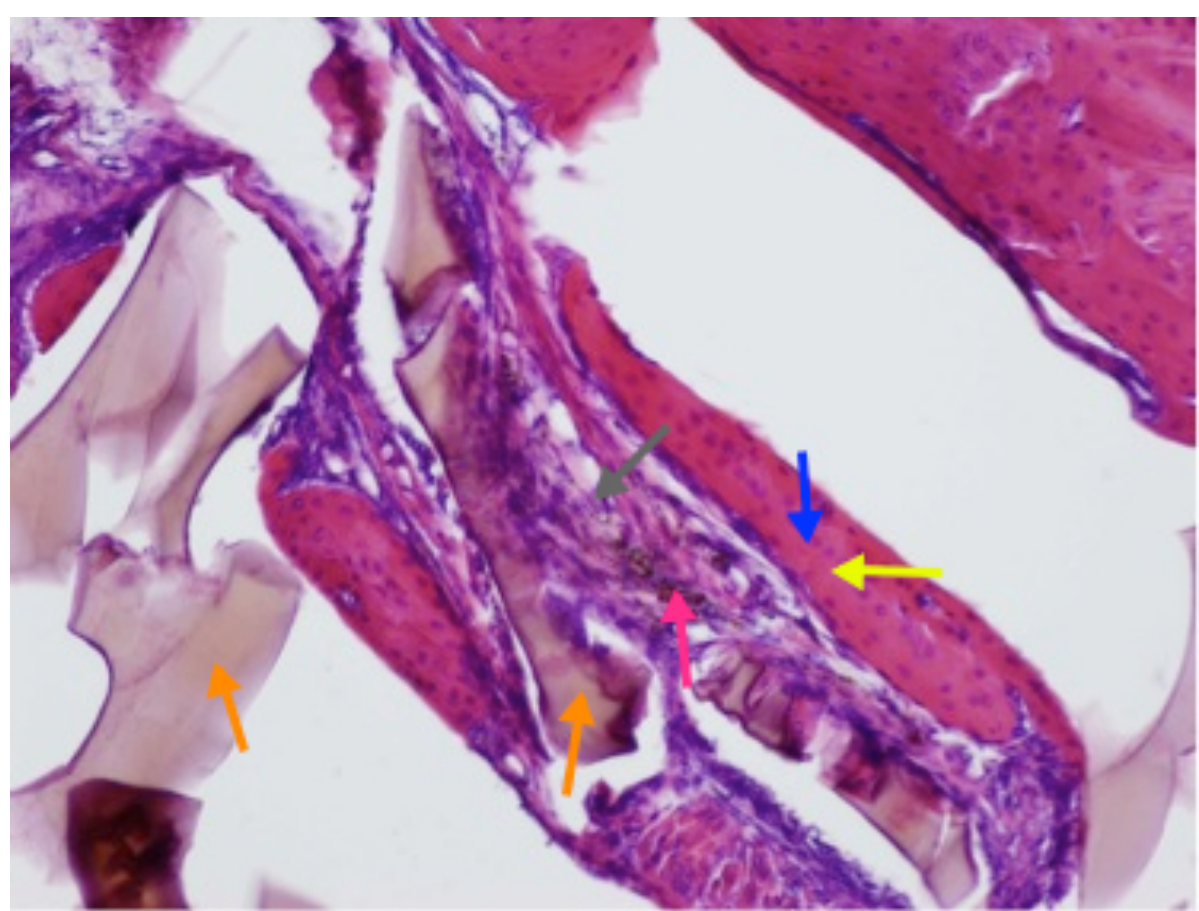

Ilustración 76. Misma imagen que la anterior obtenida con microscopio de luz a 400 aumentos de corte de mandíbula de rata de grupo II teñido con $\mathrm{H}-\mathrm{E}$ en la que apreciamos con mayor detalle el tejido conectivo laxo $(\rightarrow$ ) en contacto con restos del scaffold $(\rightarrow)$. Zonas de tejido osteoide $(\rightarrow)$ con núcleos de osteocitos $(\rightarrow$ ). Restos de hemosiderina $(\rightarrow)$. 


\section{GRUPO III: scaffold con células sembradas durante 21 días en medio osteogénico.}

\section{Hemimandíbula derecha del espécimen $n^{0} 7$.}

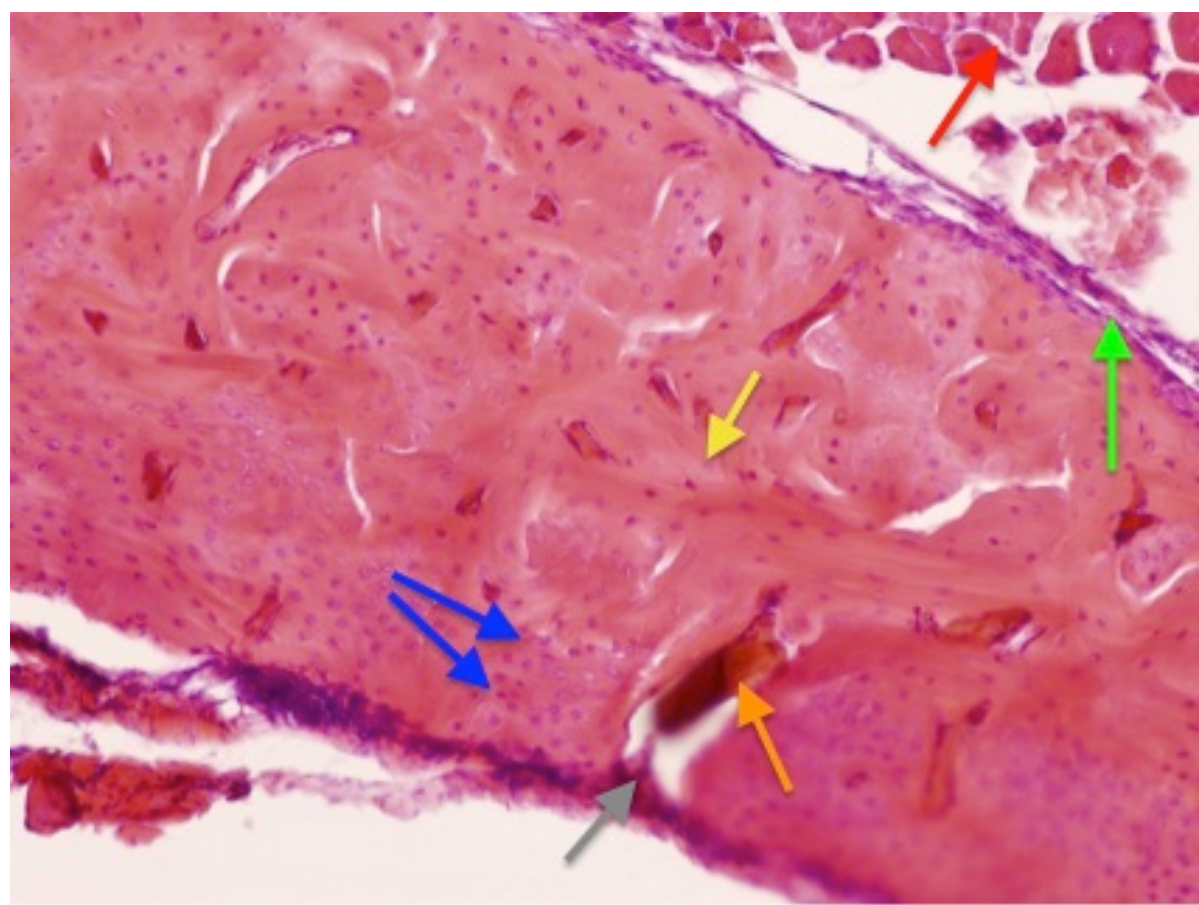

Ilustración 77. Imagen obtenida con microscopio de luz a 100 aumentos de corte de mandíbula de rata de grupo III teñido con H-E donde se aprecian restos de scaffold $(\rightarrow)$ rodeado por tejido conectivo laxo $(\rightarrow$ ). Zonas de hueso alrededor $(\rightarrow$ ) con osteocitos $(\rightarrow)$. Periostio $(\rightarrow)$ y músculo esquelético $(\rightarrow$ ) delimitando la zona.

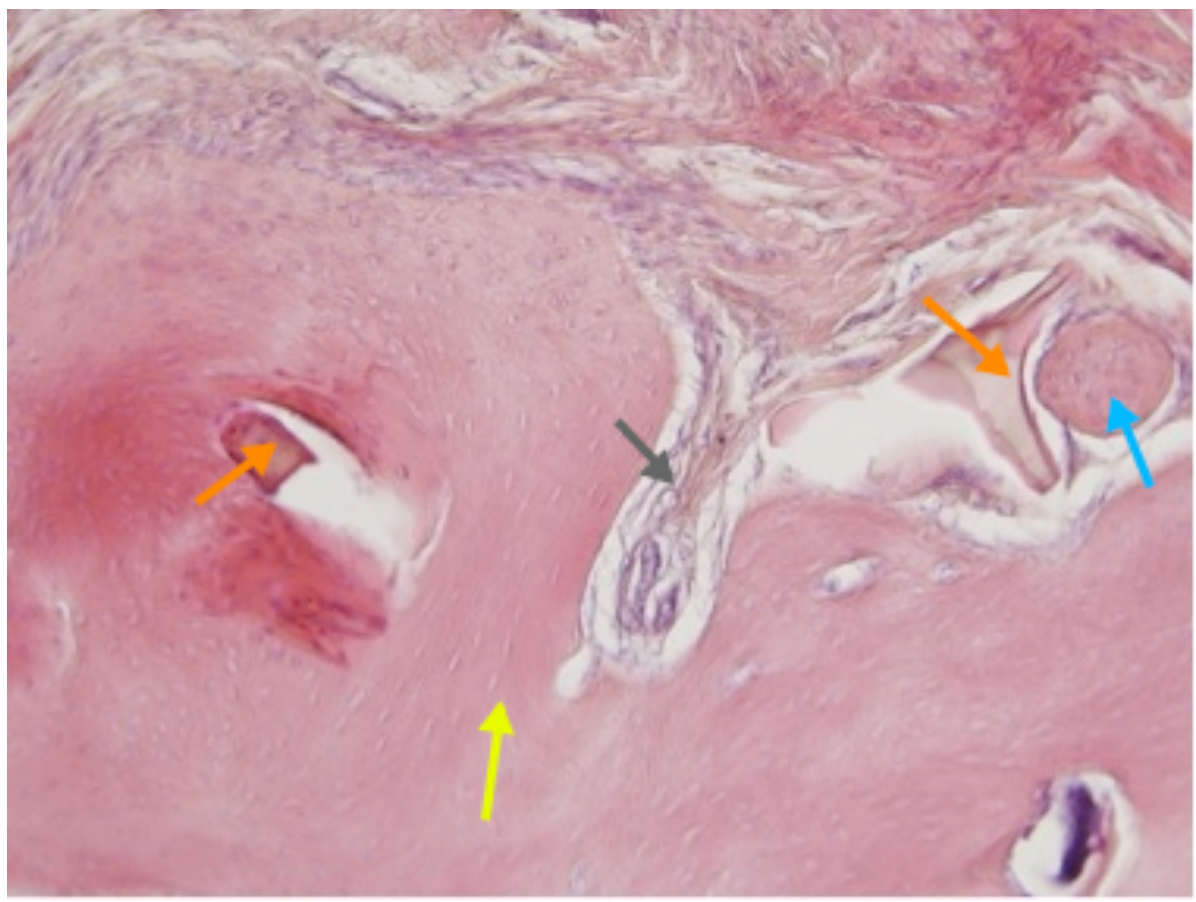

Ilustración 78. Imagen obtenida con microscopio de luz a 200 aumentos de corte de mandíbula de rata de grupo III teñido con H-E . Observamos restos de scaffold $(\rightarrow$ ) rodeado por hueso $(\rightarrow$ ) y zonas de tejido fibroso $(\rightarrow)$. Se observan fuertes zonas de osificación $(\rightarrow)$ alrededor del scaffold $(\rightarrow)$. 


\section{RESULTADOS}

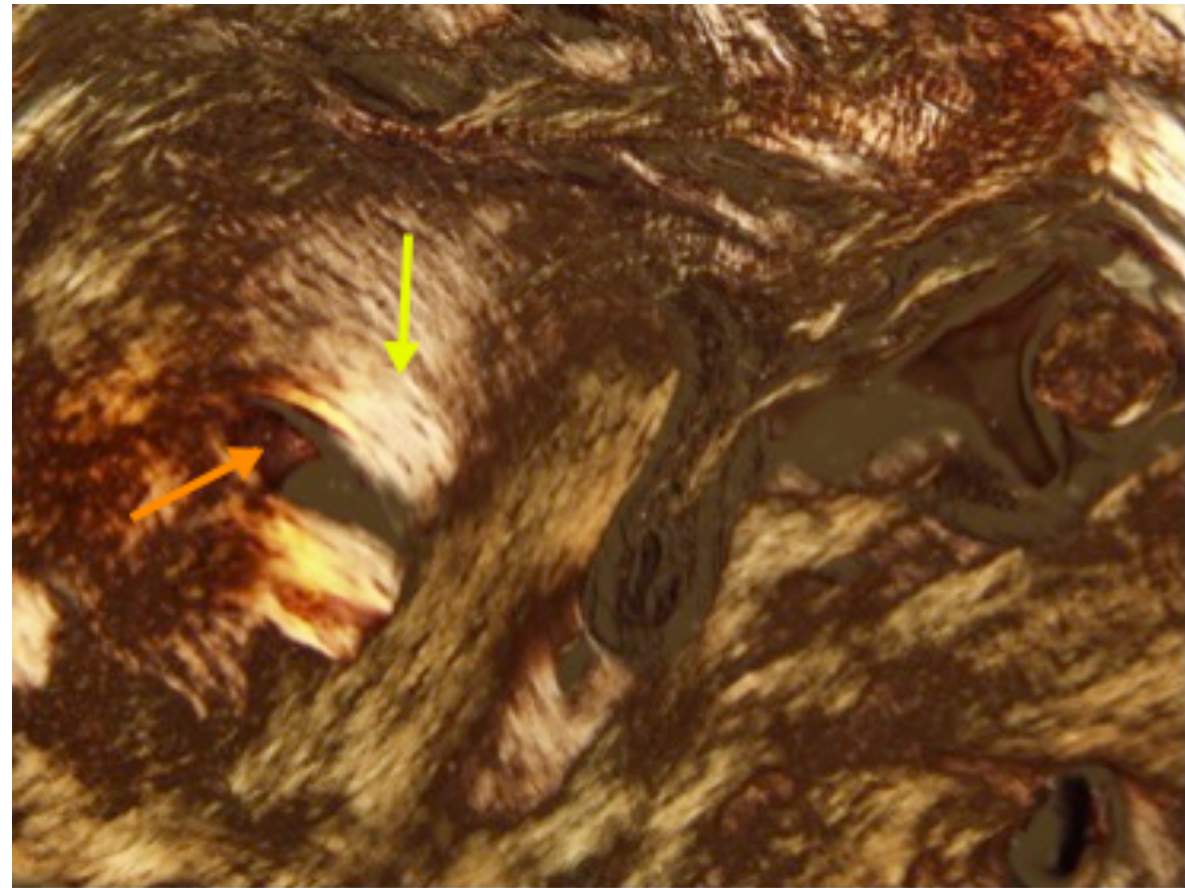

Ilustración 79. Misma imagen obtenida con microscopio de luz polarizada a 200 aumentos de corte de mandíbula de rata de grupo III teñido con H-E donde se aprecia un tejido osteoide más maduro y organizado dispuesto de forma laminar $(\rightarrow)$. Restos de scaffold $(\rightarrow)$.

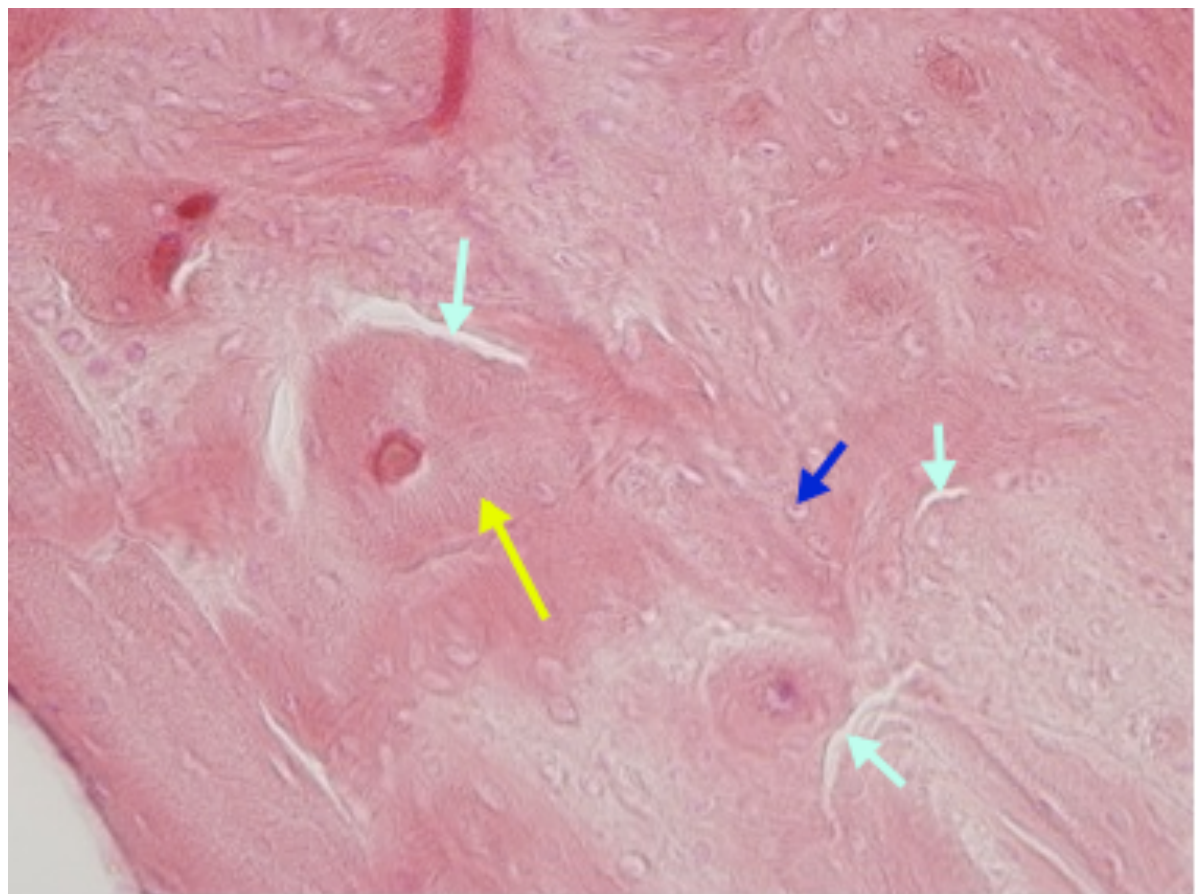

Ilustración 80. Imagen obtenida con microscopio de luz a 400 aumentos de corte de mandíbula de rata de grupo III teñido con H-E . Se observa hueso fibrilar $(\rightarrow$ ) con lagunas de osteocitos $(\rightarrow)$. Aparecen artefactos de retracción $(\longrightarrow$ ) producidos por el corte de la muestra. 
GRUPO IV: scaffold con células sin diferenciar sembradas durante 21 días.

\section{Hemimandíbula izquierda del espécimen nº 9}

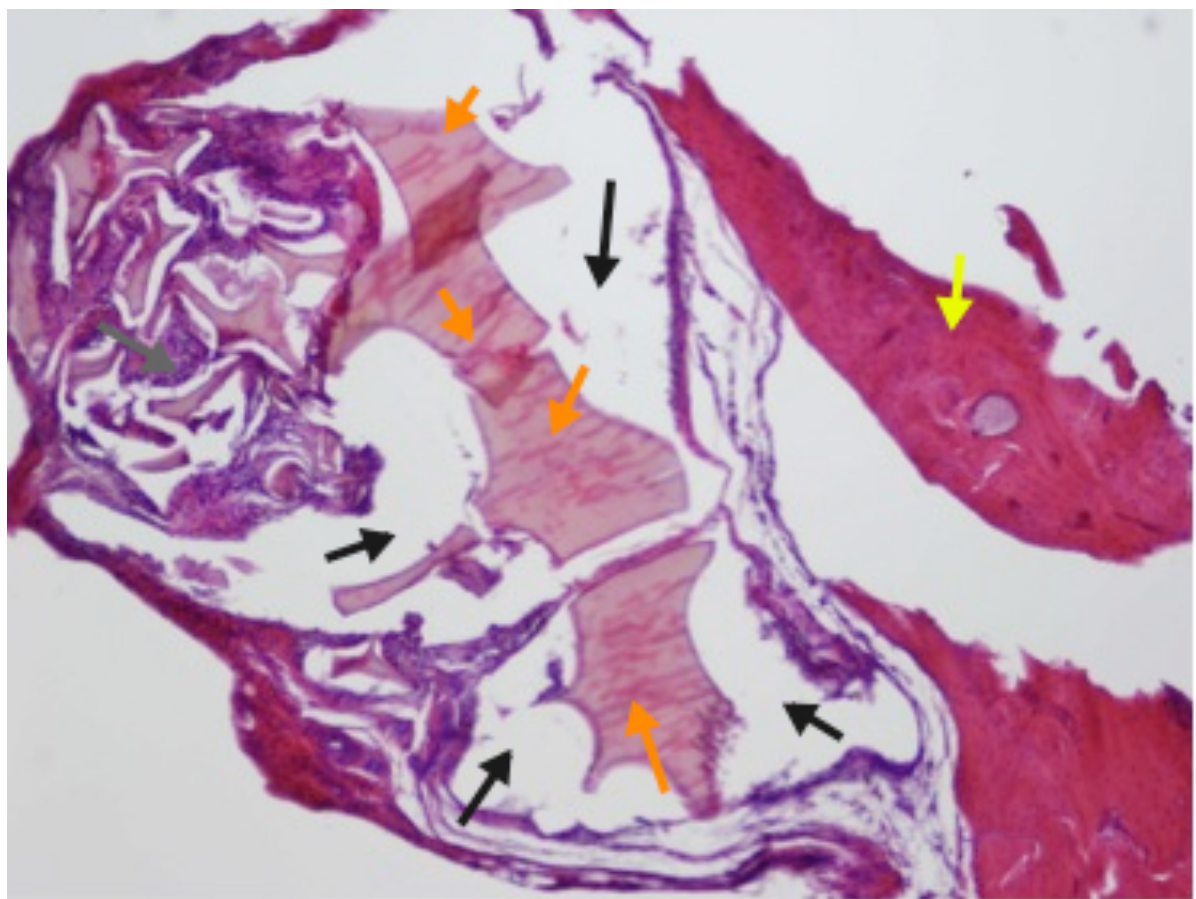

Ilustración 81. Imagen obtenida con microscopio de luz a 40 aumentos de corte de mandíbula de rata de grupo IV teñido con H-E donde apreciamos abundantes restos de scaffold $(\rightarrow)$ con tejido fibroso asociado $(\rightarrow)$ y grandes huecos vacíos $(\rightarrow$ ) donde no se ha producido formación de hueso. Zonas de hueso alejadas de los restos de scaffold $(\longrightarrow)$.

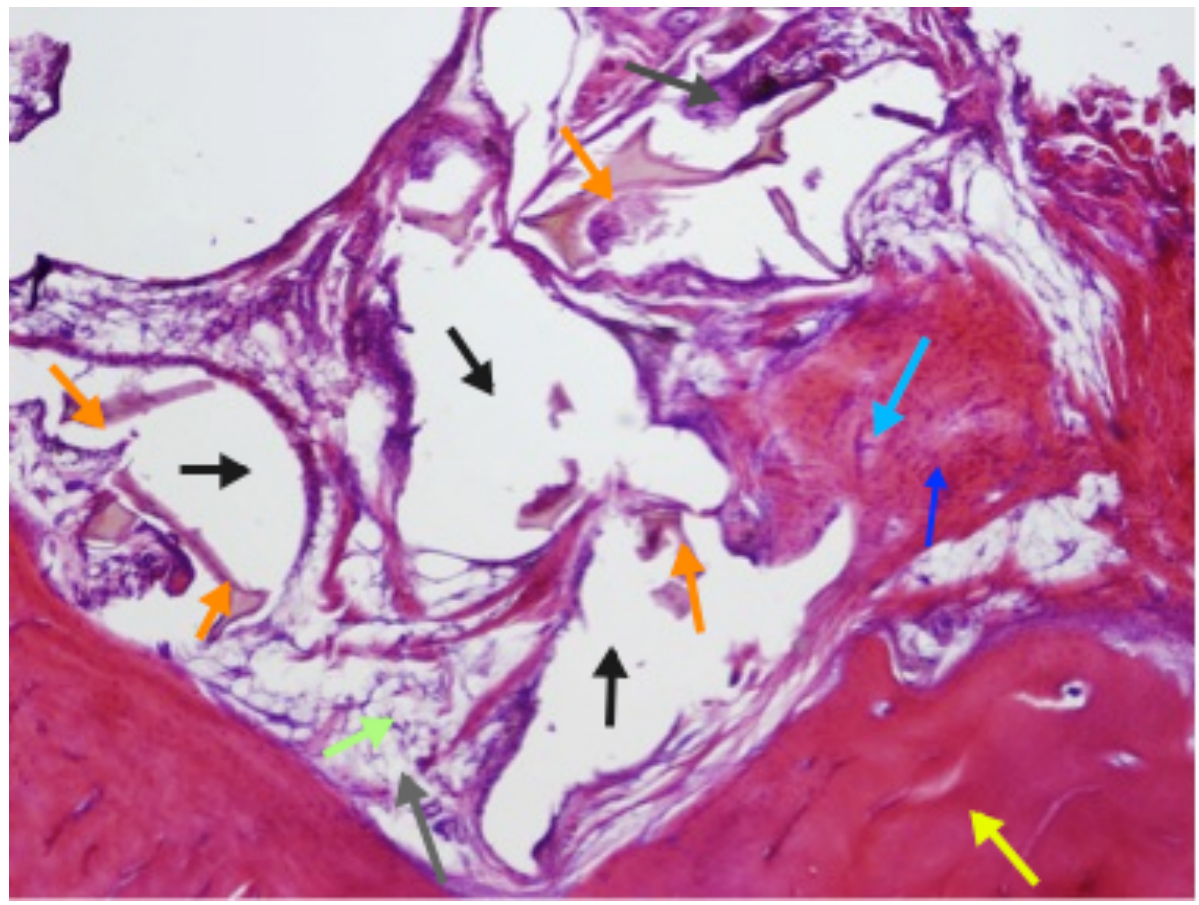

Ilustración 82. Imagen obtenida con microscopio de luz a 100 aumentos de corte de mandíbula de rata de grupo IV teñido con H-E . Grandes restos de scaffold $(\rightarrow$ ) y abundante tejido fibroso (tejido conectivo laxo) $(\rightarrow$ ) con pequeñas zonas de tejido óseo pre-existente $(\rightarrow$ ). Aparece morfología característica de fibroblasto $(\rightarrow)$ de forma más abundante y poca célula ósea $(\rightarrow)$ en zonas limitadas de huso neoformado $(\rightarrow$ ) con muchas zonas vacías $(\rightarrow)$ que pueden corresponder a zonas llenas de scaffold que al preparar el corte han desaparecido. 


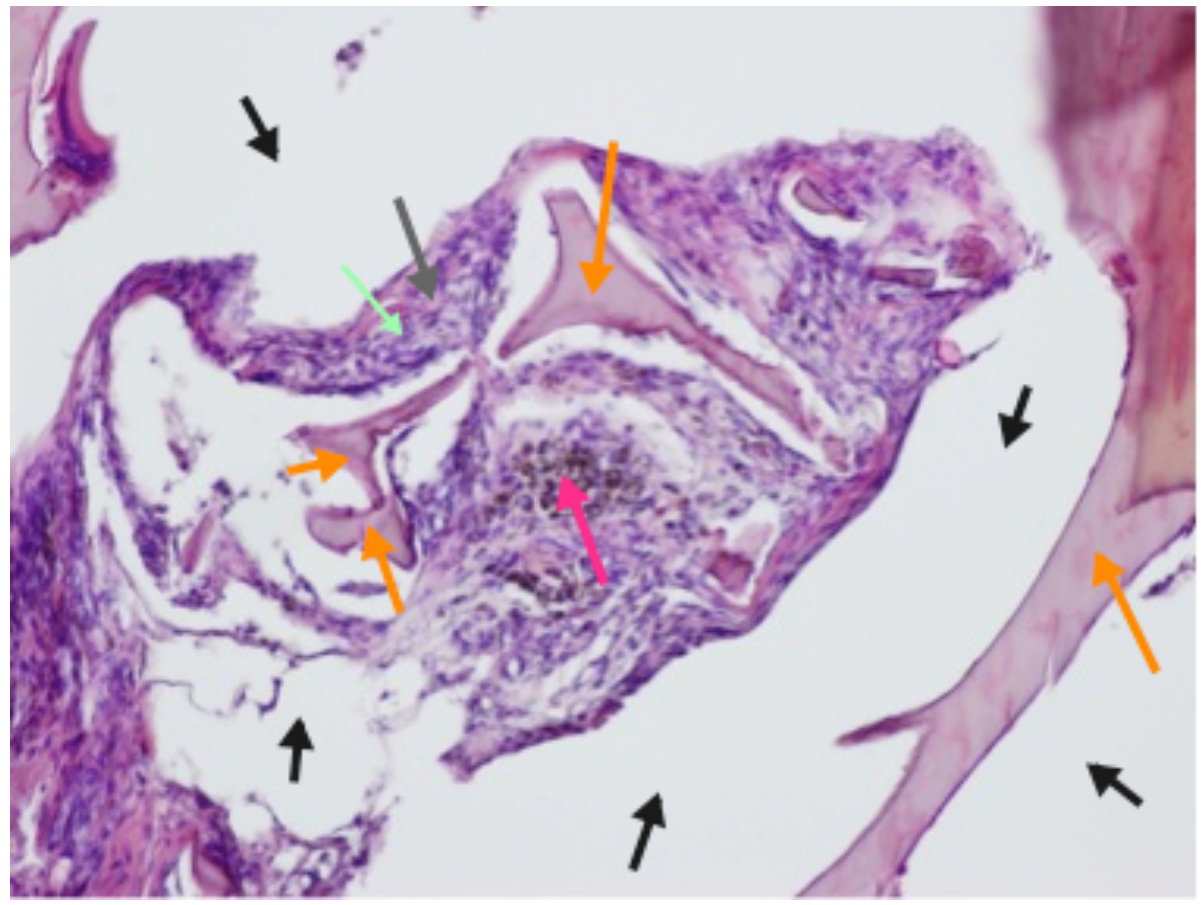

Ilustración 83. Imagen obtenida con microscopio de luz a 200 aumentos de corte de mandíbula de rata de grupo IV teñido con H-E donde se observa restos de scaffold $(\rightarrow$ ) con zonas huecas y vacías de formación de hueso $(\rightarrow$ ). Tejido fibroso $(\rightarrow)$ y fibroblastos $(\rightarrow)$, así como una coloración marronácea de restos de hemosiderina $(\rightarrow)$ producido por la herida quirúrgica. 


\section{ESTUDIO HETEROTÓPICO: ESTUDIO DE LOS INJERTOS INGUINALES}

\subsection{VALORACIÓN MACROSCÓPICA}

Durante la retirada del injerto se observa perfectamente delimitada su posición y su relación con estructuras adyacentes (ilustración 84-87). En este caso tampoco observamos diferencias en cuanto a la consistencia del injerto extraído, teniendo todos los grupos una consistencia más rígida que la consistencia gelatinosa inicial, pero fácilmente maleable a la presión digital.

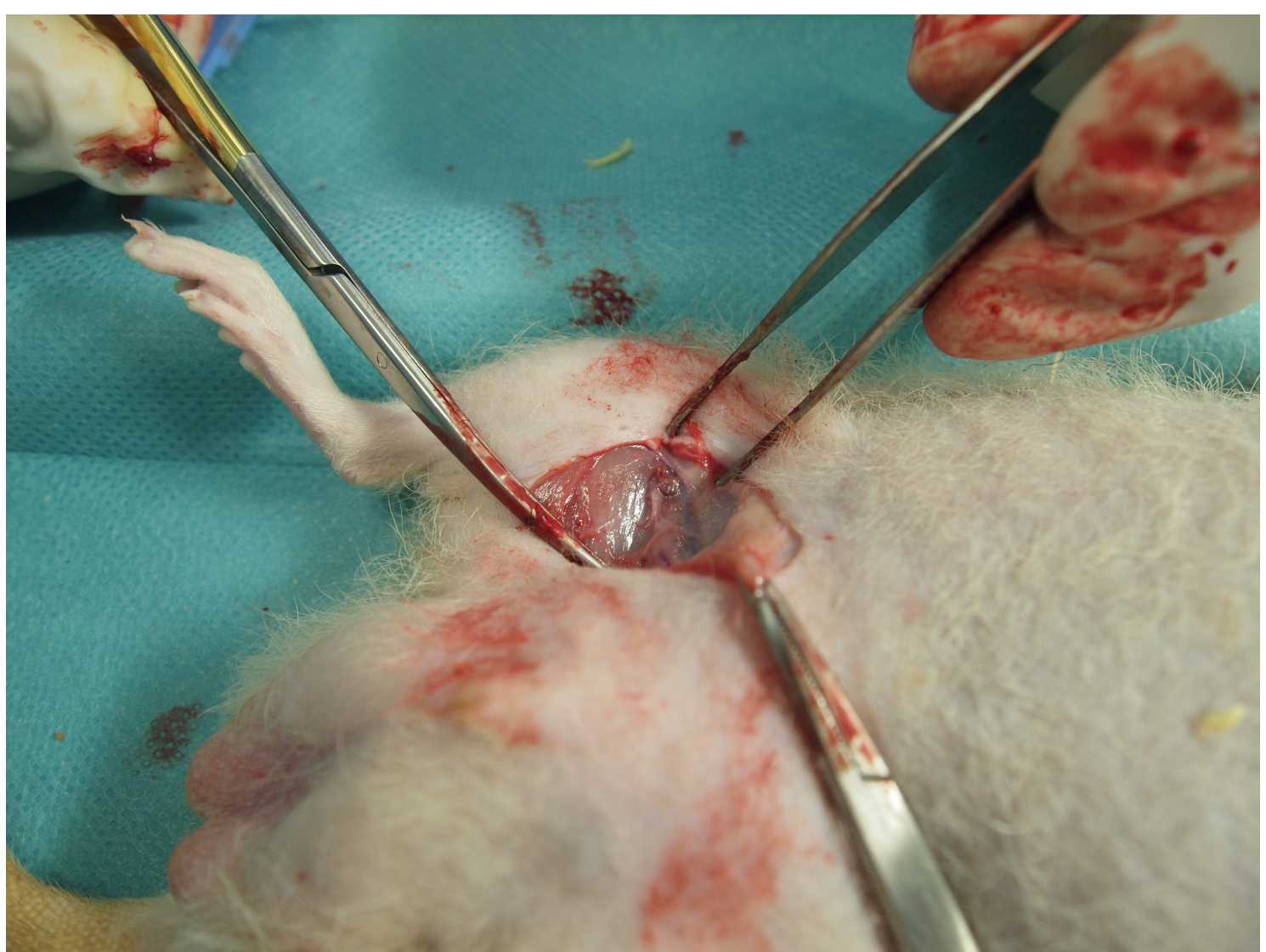

Ilustración 84. Aspecto macroscópico de injerto inguinal durante el proceso de extracción en lado derecho. 


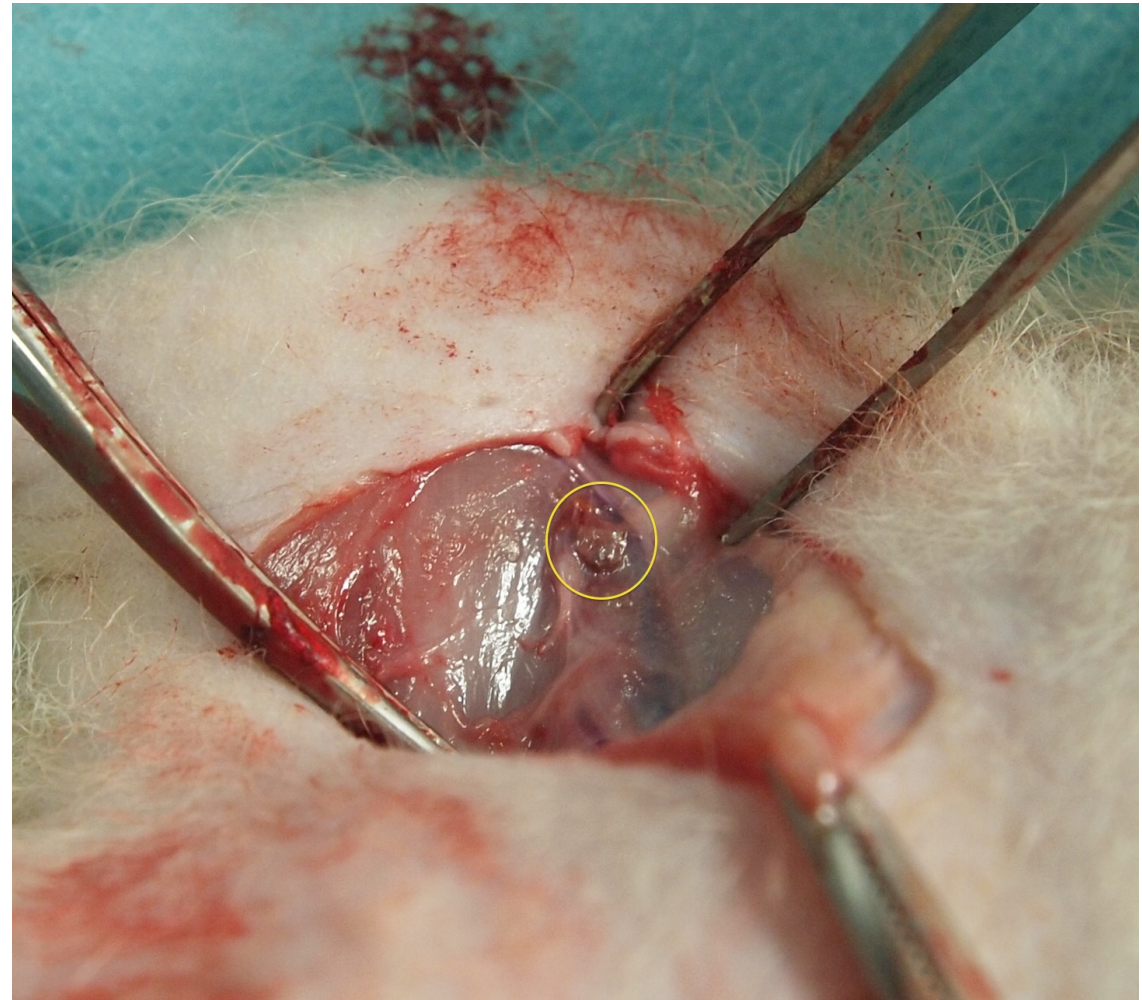

Ilustración 85. Aumento de la anterior con círculo en color amarillo rodeando el injerto. Se observa de manera muy visible la arteria nutricia próxima al injerto.

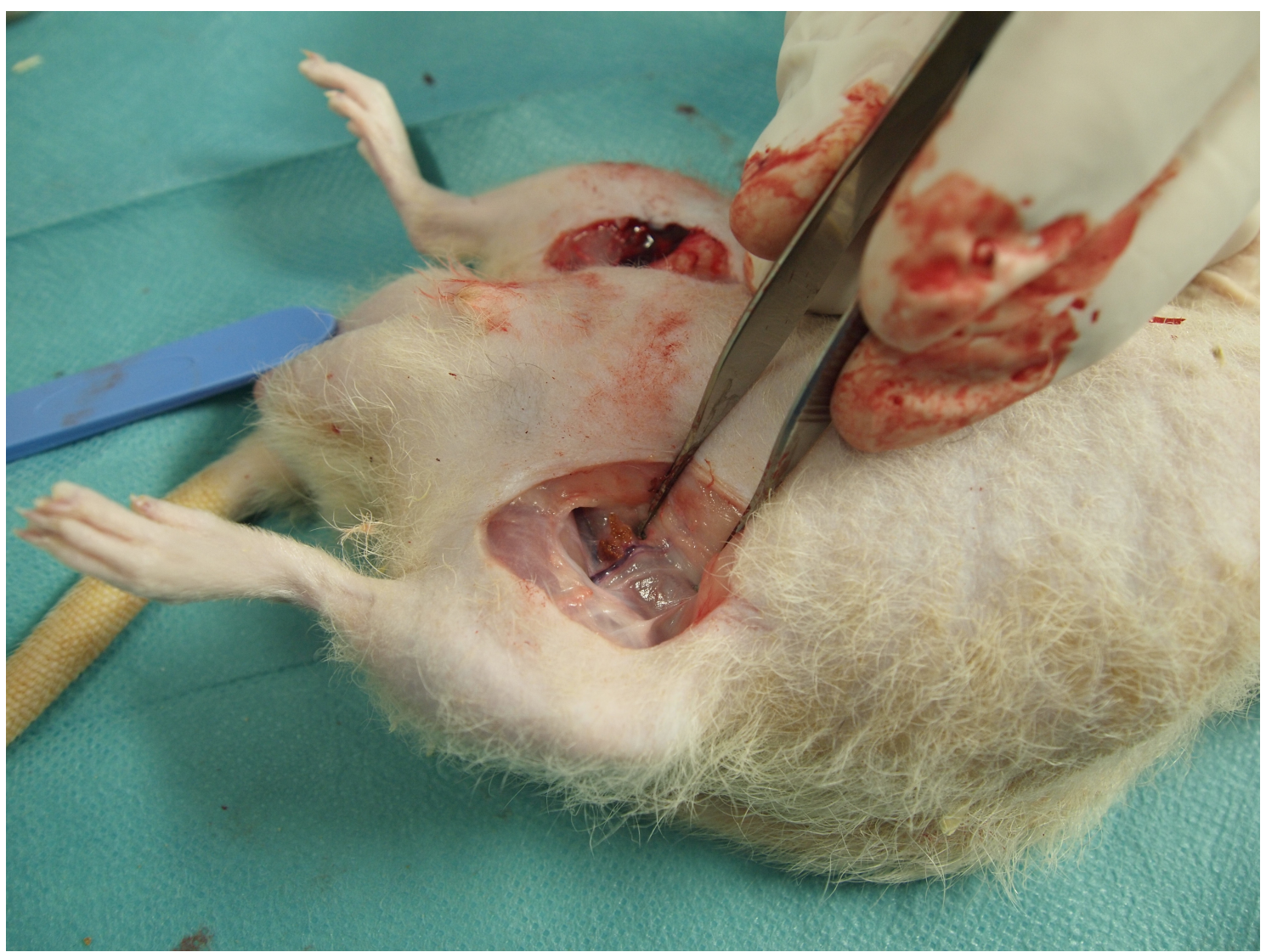

Ilustración 86. Aspecto macroscópico del injerto durante la extracción en el lado izquierdo. 


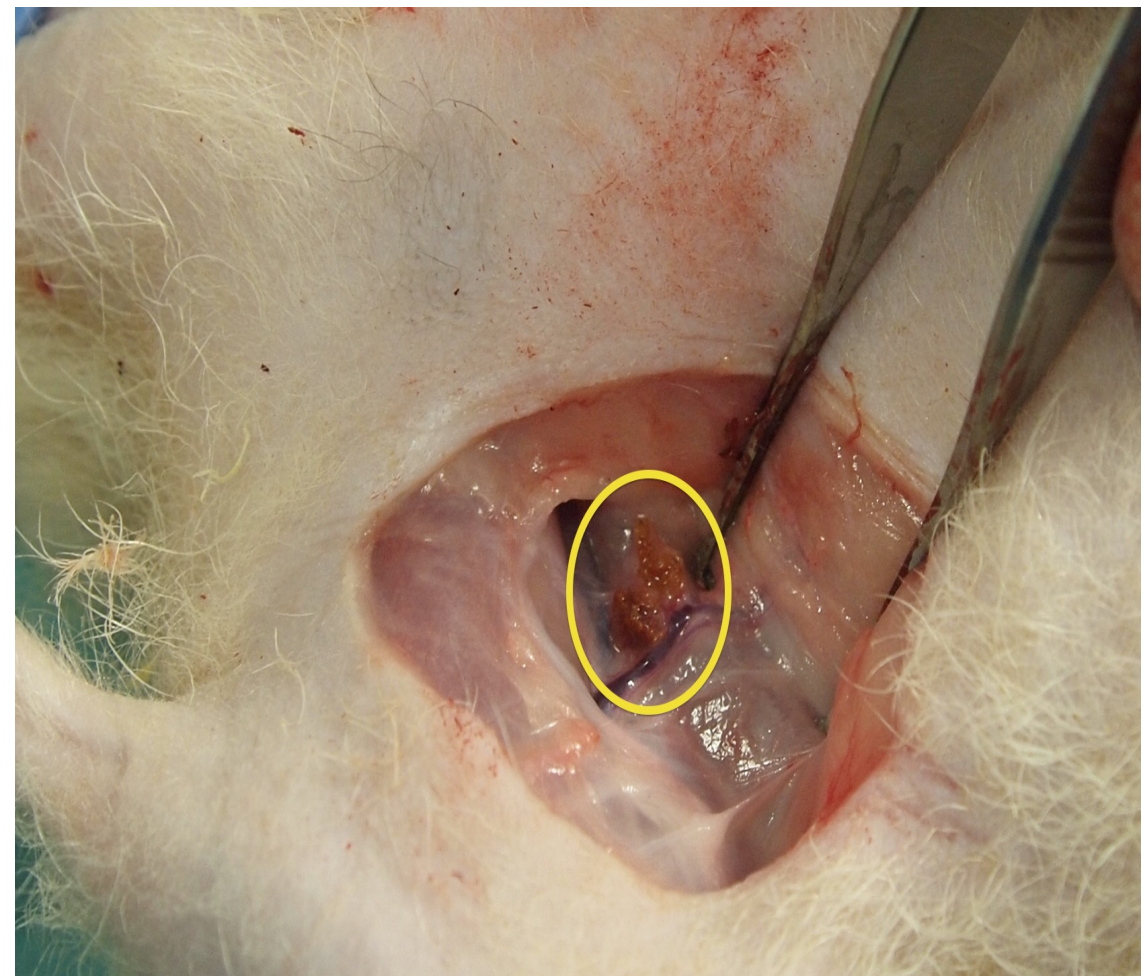

Ilustración 87. Aumento de la imagen anterior con círculo en color amarillo rodeando el injerto. Se observa de manera muy visible la arteria nutricia próxima al injerto.

\subsection{VALORACIÓN MICROSCÓPICA.}

A nivel microscópico se procede a realizar análisis histológico de dos muestras de cada grupo, a las que se somete a tinción de VK, Giemsa y H-E. Se pretende estudiar la composición cualitativa de dicho injerto fundamentalmente identificando los grupos en los que se observan núcleos de osificación para establecer una correlación con los injertos mandibulares.

De todos los grupos, solamente se observa zonas de calcificación evidentes en los cortes pertenecientes a las muestras del grupo III, es decir aquellos en los que el injerto está compuesto por la matriz y células diferenciadas en medio osteogénico durante 21 días de cultivo, lo cual se ha podido apreciar gracias a las tinciones realizadas con VK (ilustración 94 y 95). El resto de grupos no presenta signos evidentes de osificación en ninguna de las tinciones realizadas (ilustración 88-93). Llama especialmente la atención 
la neovascularización observada en algunos cortes, en los que no se ha producido formación ósea, pero sí se observan espacios vasculares neoformados relacionados a restos de scaffold (ilustración 89 y 90).

Se van a estudiar los animales $n^{\circ} 2,5,7$ y 10 tanto en el lado derecho como en el lado izquierdo.

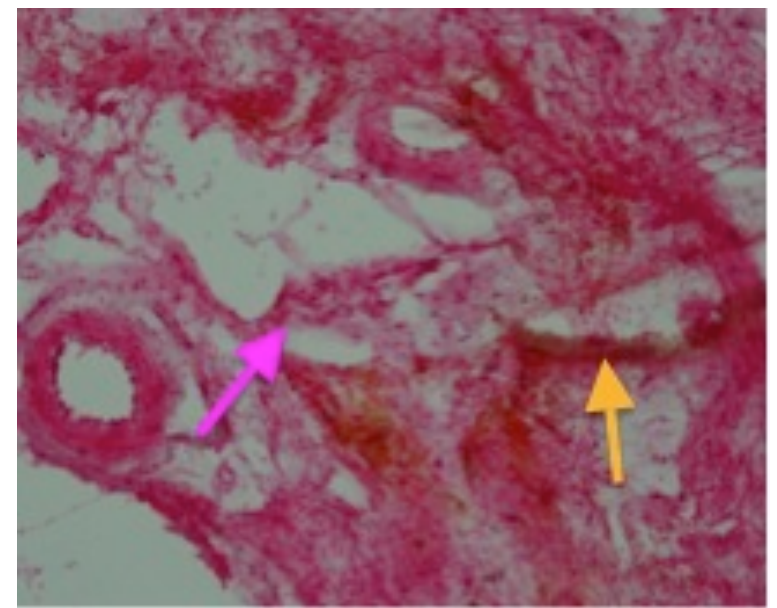

Ilustración 88. Corte profundo (17) de rata $\mathrm{n}^{\circ} 2$ lado derecho, perteneciente al grupo I. Tinción con VK a 10 aumentos. Se observa restos del scaffold $(\rightarrow)$, tejido fibrosos $(\rightarrow)$ con una coloración marronácea debido a restos de hemosiderina. Ningún indicio de calcificación.

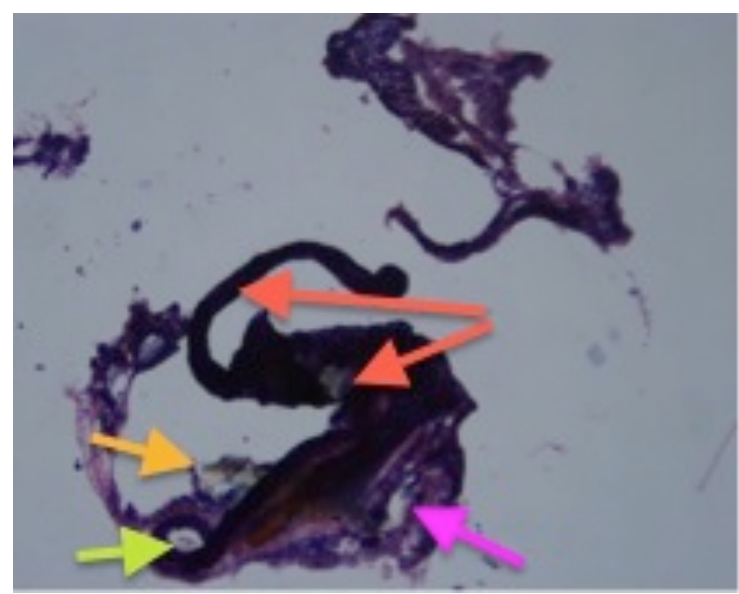

Ilustración 89. Corte profundo (18) de rata $n^{02}$ lado derecho (grupo I). Tinción Giemsa a 4 aumentos. Se observa espacio vascular $(\rightarrow)$, Éste es un punto muy importante que hay que destacar, ya que la estructura porosa de la matriz permite la neovascularización en su interior, hecho fundamental para permitir el aporte de nutrientes y oxígeno, que facilitará la neoformación ósea. Tejido musculoesquelético $(\rightarrow)$, restos de scaffold $(\rightarrow)$. Se aprecia tejido fibroso laxo $(\rightarrow)$, pero no centros de osificación. 


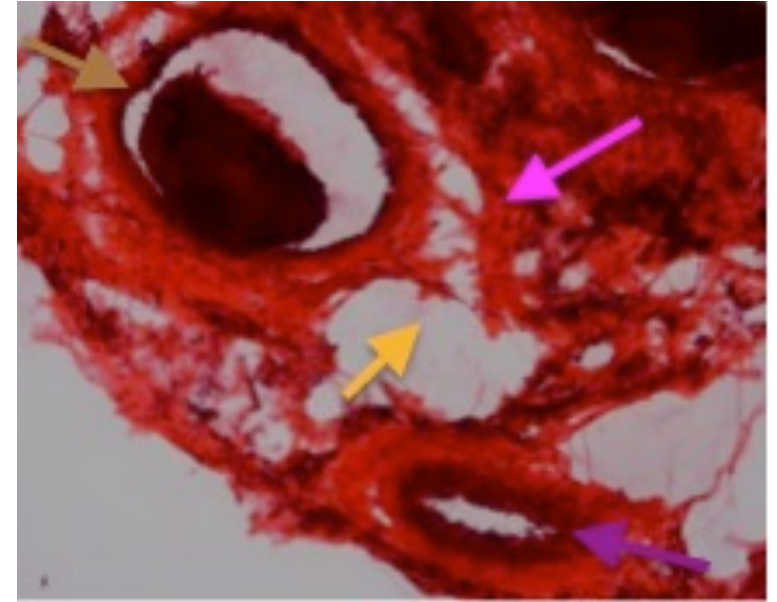

Ilustración 90. Corte profundo (20) de rata n⿳2 lado izquierdo (grupo II). Tinción H-E. Apreciamos vena con material fibrino-hemático en su interior $(\rightarrow)$, arteria $(\rightarrow)$ : muy relevante la aparición de espacios vasculares, que nos indica que el tamaño del poro del scaffold es adecuado para la formación de nuevos vasos, procedente de los tejidos adyacentes del huésped. Abundante tejido fibroso $(\rightarrow)$ y restos de scaffold en zonas vacías $(\rightarrow)$ donde intuimos se ha producido un desprendimiento del scaffold durante el proceso de la preparación del corte.

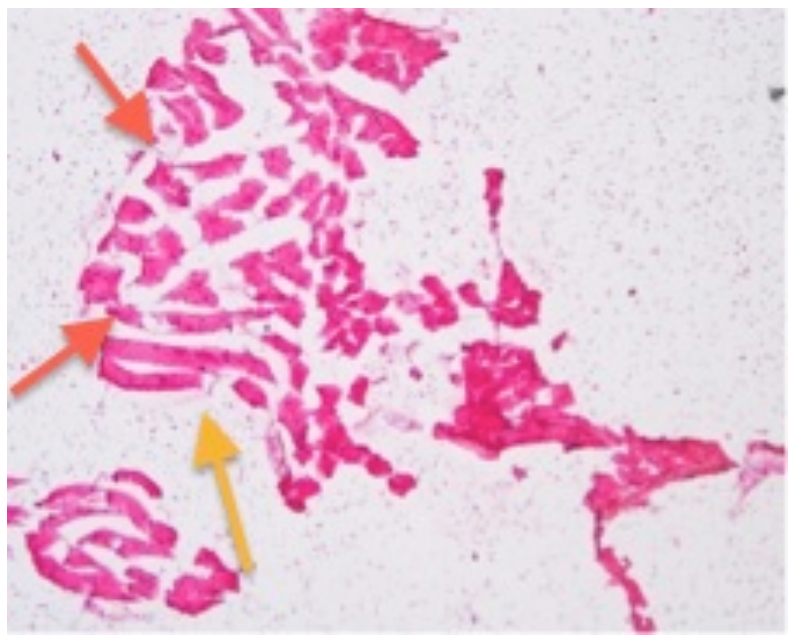

Ilustración 91. Corte profundo (17) de rata 5 lado izquierdo (grupo II) Tinción VK a 4 aumentos. No se observa la coloración característica de centros de calcificación. Solamente tejido musculoesquelético $(\rightarrow)$ y espacios huecos con lo que podrían ser restos de scaffold $(\rightarrow)$.

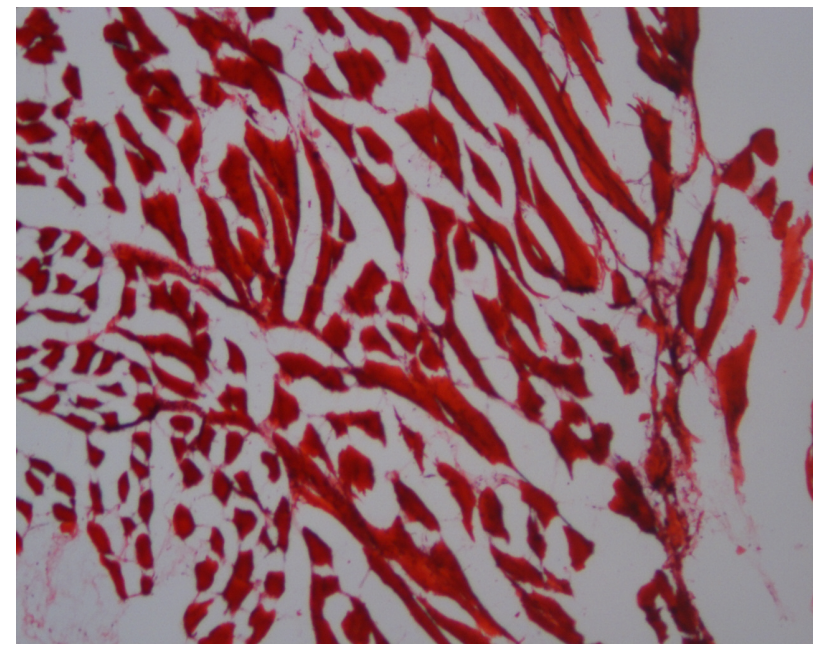

Ilustración 92. Corte profundo (20) de rata $\mathbf{n}^{0} 10$ lado izquierdo (grupo IV). Tinción con H-E. Solo se observa tejido musculo-esquelético. 


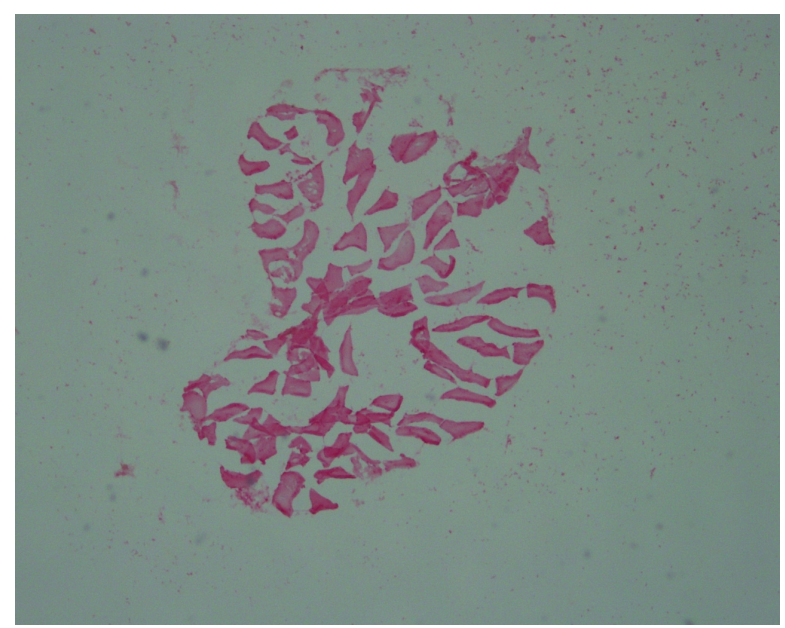

Ilustración 93. Corte intermedio (16) de rata $n^{0} 7$ lado izquierdo (grupo IV). Tinción con VK a 4 aumentos. Solo se observa músculo, no se aprecia ningún núcleo de calcificación.

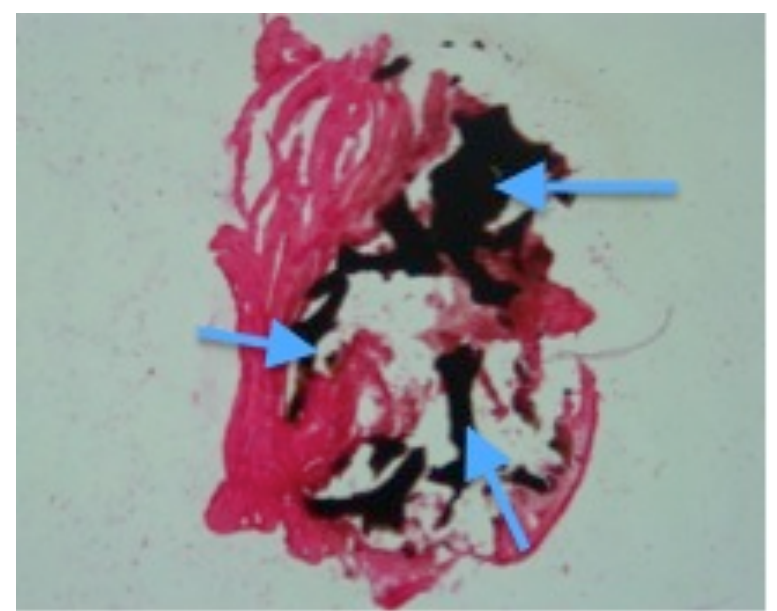

Ilustración 94. Corte superficial $\left(n^{\circ} 3\right)$ de rata $n^{07}$ lado derecho (grupo III). Tinción con VK positivo a 4 aumentos en el que se observa claramente la tinción muy marcada que nos indica zonas de calcificación $(\rightarrow), \mathrm{y}$ por tanto existe diferenciación hacia linaje osteoblástico.

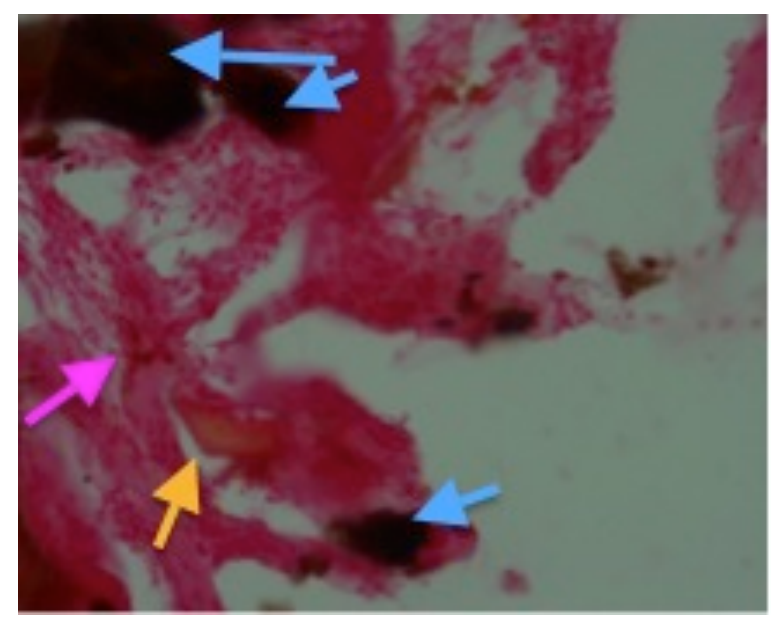

Ilustración 95. Corte profundo de rata $\mathbf{n}^{0} 7$ lado derecho (grupo III). tinción VK positiva a 20 aumentos. Se observa marcada tinción de color negro azulado indicando zonas de calcificación $(\rightarrow)$. Se observan restos de scaffold $(\rightarrow)$, así como tejido fibroso $(\rightarrow)$. 



\section{V.DISCUSIÓN}





\section{DISCUSIÓN DE LA METODOLOGÍA}

\subsection{MODELO ANIMAL}

La aplicación de cualquier tratamiento o técnica en seres humanos necesita obligatoriamente su evaluación en estudios preclínicos con animales de experimentación. En el caso que nos ocupa, la regeneración ósea, antes de llevar a cabo investigación en animales grandes es necesario profundizar en el estudio en modelos animales filogenéticamente inferiores que nos permita validar unas condiciones fisiológicas en los procesos de regeneración. La elección de un correcto modelo animal es fundamental para el éxito de los estudios preclínicos. La opción de roedores para estudios del comportamiento de materiales con finalidad reparativa en el hueso está sobradamente contrastado en la literatura (Schmitz y Hollinger, 1986; Liebschner, 2004). En nuestro estudio, la utilización de un modelo murino, concretamente la rata, representa una serie de ventajas, ya que la alta actividad metabólica de estos animales y como consecuencia su alta tasa de remodelación ósea, los hace ideales para modelos de regeneración, pudiendo obtener los resultados de generación tisular en un corto plazo de tiempo, así como la comparación de los resultados obtenidos con los de otros trabajos, debido a la estandarización de los estudios en regeneración ósea experimental. Aunque algunos autores (Urist y cols. 1982) expresan ciertas dudas en la utilización de estos animales precisamente por el alto índice metabólico y por ello, el elevado potencial osteogénico.

Otro factor muy importante en la elección de nuestro animal de experimentación fue la necesidad de utilizar ratas con aplasia del timo, y por tanto, con su sistema defensivo disminuido, de tal manera que pudiéramos llevar a cabo la implantación de células de 
origen humano sin generar una respuesta inmunológica que pudiera condicionar los procesos de recuperación postquirúrgicos y evitar así un rechazo al injerto implantado.

De este modo poder valorar si la celularidad de las muestras obtenidas de los defectos mandibulares creados tras la implantación, tienen un origen humano o su procedencia es la del propio animal. Para este cometido, lo ideal hubiera sido llevar a cabo un análisis inmunohistoquímico de las muestras y poder determinar así, si el origen del hueso neoformado es humano o del propio huésped, pero por motivos de índole económico no pudimos realizar dicha comprobación. A pesar de ello está justificada la elección de dicho animal ya que este trabajo continua la línea de investigación iniciada en el año 2009 por la Dra. Gallego, permitiéndonos comparar los resultados de ambos trabajos. Además de comprobar los procesos de regeneración ósea a nivel mandibular, quisimos comprobar el comportamiento de los injertos fuera de la mandíbula a nivel inguinal. Una vez escogido nuestro modelo de rata atímica desnuda, observamos que presenta una serie de ventajas, debido a que la obtención del injerto a partir de la exodoncia de cordales en humanos no genera ninguna morbilidad y es algo que no supuso ninguna dificultad, sin embargo, someter a los animales a dos cirugías (la primera para la extracción del injerto) podría suponer un riesgo para el animal. Del mismo modo, para conseguir una expansión celular del cultivo in vitro, previa a la implantación, para conseguir tal número de células, nos obliga a acudir a cortical humana, puesto que necesitaríamos intervenir a un alto número de animales de esta especie realizando extirpaciones de fémur completo, ya que necesitaríamos la medular de dicho hueso para realizar las preparaciones celulares que necesitamos. Por todo ello, en nuestro estudio vamos a utilizar rata mutante atímica desnuda, cuyo uso está contrastado en numerosos estudios, como los realizados en evaluación de xenoinjertos (Bäuerle Y cols, 2006; Buursma y cols, 2005; Dauchy y cols, 2004), regulación de la 
carcinogénesis (Chen y cols, 2002; Siegall y cols, 1994; Svechnikova y cols, 2003), terapia tumoral (Burch y cols, 2005; Dauchy y cols, 2004; Sauer y cols, 2005) o angiogénesis tumoral (Amirkhosravi y cols, 1998; Cabrera y cols, 2006).

\subsection{MODELO QUIRÚRGICO}

Los defectos óseos experimentales en calota de animales es un procedimiento muy frecuente para los estudios de regeneración de hueso (Gupta y cols, 2008). En el caso de la rata requiere la realización de defectos óseos críticos en calota de $8 \mathrm{~mm}$ (Takagi y Urist, 1982; Schmitz, y cols, 1990), lo cual supone un inconveniente técnico al tener que aproximarse a estructuras muy comprometidas como la duramadre. No obstante, cuando queremos determinar la máxima efectividad del material injertado en cirugía cráneomaxilofacial, debemos realizar el estudio sobre mandíbula (Boyne, 1980), ya que presenta una serie de características que la hacen única en el territorio maxilofacial, como es su movilidad y el estrés mecánico al que se ve sometida por la potente acción muscular y las cargas masticatorias. Esto hace que los procesos de reparación ósea sean especialmente complejos cuando afectan a la mandíbula (Kaban y Glowacki, 1981). Otras técnicas emplean procedimientos quirúrgicos interrumpiendo la continuidad de la mandíbula, utilizando modelos de distracción ósea mandibular, lo cual genera un procedimiento difícilmente reproducible por la dificultad técnica que representa $(\mathrm{Hu}$ y cols, 2007)

La finalidad de la cirugía es poder acceder al hueso mandibular y generar un defecto crítico, es decir no autorregenerable, que permita la colocación de nuestro injerto. De est modo, pretendemos evaluar las propiedades osteorregenerativas de nuestros injertos. El limitado acceso quirúrgico en nuestro modelo animal genera una serie de dificultades 
que nos llevan a considerar la creación de un defecto sin interrupción de la continuidad del hueso (Schmitz y Hollinger, 1986), por tanto un defecto circular intraóseo de $4 \mathrm{~mm}$ de diámetro situado a nivel del ángulo mandibular, en continuidad con la rama ascendente (Kaban y Glowacki, 1981). La realización de este tipo de defecto de $4 \mathrm{~mm}$ en los estudios de regeneración ósea en ratas, ha sido contrastado por distintos autores y utilizado en distintos ensayos siendo un modelo fiable que presenta varias ventajas, entre ellas, la preservación de la continuidad mandibular, comentada anteriormente. Además es un defecto que no muestra capacidad autorreparativa: está constatada la invasión por tejido cicatricial impidiendo la regeneración ósea en defectos mandibulares de $4 \mathrm{~mm}$ e impidiendo el reposicionamiento del periostio, lo cual evita los posibles efectos osteorregenerativos no atribuibles a la matriz (Jones y cols, 1996; Lorente y cols, 1992). Otra ventaja que ofrece la realización de este tipo de defecto, es que la acción del potente músculo masetero genera una barrera que confiere estabilidad al injerto, evitando movilizaciones que pudieran afectar a la prosperidad del injerto.

\subsection{SCAFFOLD}

Tanto la experiencia clínica como diferentes estudios, nos muestran las ventajas de utilizar hueso autólogo fresco como el mejor de los injertos para reparar los defectos óseos. Sin embargo, existen distintos problemas a la hora de usar autoinjertos en la región craneofacial como es la morbilidad de la zona donante, así como la limitación en la cantidad de hueso disponible, fundamentalmente en niños. Además, el contorno irregular con zonas anguladas del injerto dificulta el posicionamiento y estabilidad del mismo. Otro aspecto negativo en el uso de este tipo de injertos es la impredecibilidad en la reabsorción de los mismos (Mulliken y cols, 1980). Pero realmente ¿qué es lo que se 
necesita para que se produzca un crecimiento de hueso? Desde un punto de vista biológico se necesitan células, matriz extracelular, puentes de unión intercelular, interacción de la matriz extracelular con las propias células y factores de crecimiento. Pero además, es necesario un medio capaz de soportar los componentes anteriormente citados y que imite del mejor modo posible, la estructura tridimensional del hueso que va a remplazar. La matriz extracelular, que hasta hace poco tiempo no recibía el protagonismo que ahora presenta, es primordial para la organización de los distintos tejidos y participa de forma dinámica en la interacción entre células, y entre células y las distintas moléculas que forman dicha matriz, contribuyendo a la migración, proliferación, diferenciación, morfología, metabolismo y la consecuente muerte celular (Uitto, y cols, 1989).

La matriz extracelular proporciona un soporte estructural y un ambiente físico necesarios para que las células residentes en el tejido puedan estabilizarse en él, crecer, migrar y responder a distintos estímulos (Langer y cols, 1993; Kneser y cols, 2002) proporcionado señales específicas a las células para que puedan interactuar con el ambiente (Yim y cols, 2005). También proporciona al tejido propiedades mecánicas como la rigidez o elasticidad específica para cada tipo de tejido; por ejemplo las fibras de colágeno tipo I organizadas en los tendones presentan un rigidez muy alta que les confiere resistencia, mientras que las fibras de colágeno de la piel presentan una distribución que confiere a la piel dureza y elasticidad.

Otra función muy importante de la matriz extracelular es que actúa también como reservorio de factores de crecimiento permitiendo su actividad, como por ejemplo el proteoglicano de sulfato de heparina que facilita la actividad de $\beta-F G F$ (factor de crecimiento fibroblástico- $\beta$ ) (Schönherr y cols, 2000). Además la matriz extracelular debe permitir su degradación facilitando la neovascularización y el remodelado del 
tejido en respuesta a los procesos dinámicos de reparación.

Por lo tanto el mejor scaffold que existe es la matriz extracelular. Por eso el desarrollo de cualquier scaffold persigue imitar en lo máximo posible las funciones de dicha matriz extracelular. De aquí la gran importancia que tiene el diseño del scaffold en los procedimientos de ingeniería tisular (Spector y cols, 2006; Muschler y cols, 2004; De Santis y cols, 2015).

Muchos han sido los scaffolds utilizados por distintos autores en distintos ensayos, tanto naturales como sintéticos, lo cual nos da una idea de la complejidad y exigencias que un scaffold ideal debe poseer. No obstante, todos ellos deben poseer una serie de propiedades esenciales:

- Biocompatibilidad. Cualquier material implantado debe evitar la posibilidad de provocar ningún tipo de rechazo en el huésped (Hutmacher y cols, 2000; Agrawal y cols 2001; Leong y cols, 2003; Yang y cols, 2001). En nuestro estudio utilizamos una matriz de origen humano (scaffold Meana) que implantaremos en el animal de experimentación, pero pensando en un futuro uso clínico, lo que se pretende es elaborar una matriz a partir de material autólogo utilizando albúmina del plasma sanguíneo del propio paciente, asegurándonos de este modo la compatibilidad del material, eliminando el riesgo de respuesta inmune por parte del huésped (Meana y cols, 2008; Gallego y cols, 2010).

- Estructura arquitectónica. El scaffold debe poseer una estructura porosa. En este punto el tamaño del poro juega un papel fundamental para permitir el crecimiento celular, así como facilitar un suficiente aporte vascular. Está bien aceptado el uso de poros con un tamaño que oscila entre 200-900 $\mu \mathrm{m}$ 
(Yang y cols, 2001; Maquet y cols, 1997; Freed y cols, 1998; Burg y cols, 2000; Zadpoor, 2015). En nuestro trabajo, el scaffold utilizado presenta un tamaño de poro de $300 \mu \mathrm{m}$, que es un tamaño que permite la estabilidad, crecimiento y proliferación celular. Las pruebas de microscopía electrónica de barrido llevados a cabo en los trabajos de la Dra. Gallego nos permite confirmar la existencia de grupos de osteoblastos alojados en los poros del scaffold, apreciándose numerosos puentes intercelulares. No obstante, otros autores como Holly en el año 2000 defiende un concepto totalmente distinto, en el que cree que el crecimiento óseo sólo se producirá utilizando matrices tridimensionales con macroporos en un rango de 1,2 a 2,0 mm (Holly y cols, 2000). Ciertamente este concepto de porosidad ofrece ciertas ventajas en cuanto a permitir el crecimiento de vasos en el interior, pero desde el punto de vista de sus propiedades mecánicas no es el más conveniente, por eso este concepto no está muy extendido. Podemos confirmar la presencia de elementos vasculares en el interior de los injertos, constatado gracias al estudio histológico de los injertos implantados heterotópicamente, lo que nos indica que el tamaño del poro del scaffold utilizado, aunque se podría considerar pequeño, permite la neovascularización del nuevo tejido.

- Propiedades de la superficie. El scaffold debe poseer unas propiedades químicas que favorezca la adhesión celular, así como propiedades topográficas que favorezcan la proliferación celular, modulando los procesos de osteoconducción (Lange y cols, 2002; Assinelli y cols, 2003; Shadjou y cols, 2015). El scaffold que utilizamos, gracias al uso de albúmina y glutaraldehido, permite la adhesión celular (comprobada mediante 
microscopía electrónica de barrido) y el crecimiento y proliferación celular (confirmado mediante distintas técnicas de análisis histológico e inmunohistoquímico: tinción de VK, H-E, fosfatasa alcalina). Este aspecto también está contrastado en los trabajos de la tesis doctoral de la Dra. Gallego (Gallego, 2009). El glutaraldehido es una sustancia no apropiada para la fabricación de matrices, y aunque favorece la adhesión celular, hace que la matriz sea poco degradable y el remanente sea muy tóxico para las células (Hollander y cols, 2004). Una opción para situar células en el interior es mezclar la albúmina con partículas de carbonato cálcico, lo cual obliga a tratar la mezcla con soluciones ácidas para eliminar dichas partículas, permaneciendo el glutaraldehido residual que sigue siendo muy tóxico. En la matriz de nuestro experimento se elimina la sustancia entrecruzante (glutaraldehido) mediante un proceso de liofilización, que además favorece la porosidad del material (Meana y cols, 2008).

- Propiedades mecánicas. El scaffold debe tener la suficiente resistencia mecánica para soportar la presión hidrostática y mantener el espacio necesario para el crecimiento celular y la producción de matriz extracelular, soportando el estrés continuo al que es sometido el tejido óseo (Leong y cols, 2003; Hutmacher y cols, 2000; Shamaz y cols, 2015). El scaffold Meana presenta una gran resistencia y elasticidad, ya que una vez liofilizada la mezcla albúmina-agente entrecruzante, se vuelve a hidratar mediante el empleo de distintas concentraciones decrecientes de etanol, obteniendo un soporte flexible y poroso, que puede ser cortado con facilidad sin riesgo de fractura (Meana y cols, 2008), obteniendo la forma y tamaño del injerto que 
necesitamos para reparar el daño tisular, en nuestro caso pequeños cilindros con base de $4 \mathrm{~mm}$ de diámetro correspondiente al diámetro del defecto creado y altura de $2 \mathrm{~mm}$ para poderlo posicionar en la zona del defecto. Sin embargo, podemos encontrar limitaciones en el uso de este scaffold en aquellas zonas donde se requiera soportar altas cargas, ya que su dureza es limitada, como por ejemplo en grandes segmentos mandibulares, donde estaría más indicado el uso de matrices basadas en materiales fosfatocálcicos o metálicos que tengan mayor dureza.

- Biodegradabilidad. La degradación del scaffold debe ser apropiada al crecimiento del nuevo tejido, de manera que cuando el daño sea totalmente reparado el scaffold debe haber sido totalmente degradado (Langer y cols, 1993). Este concepto se conoce como creeping substitution y hace referencia a la capacidad que tiene el scaffold para ser sustituido por tejido neoformado a medida que va desapareciendo (Huang y cols, 2014). La naturaleza proteica del scaffold Meana, juega un papel primordial en su biodegradabilidad, ya que las proteínas del suero generan señales que activan a los macrófagos que participan en su degradación y permitiendo que dichas sustancias de degradación generadas se eliminen por el organismo sin producir ningún tipo de toxicidad. El Scaffold utilizado muestra una respuesta inflamatoria muy moderada en la zona del trasplante con una degradación paulatina y controlada del material, como hemos podido observar en los resultados histológicos donde no apreciamos signos de reacción inflamatoria aguda ni crónica, ni reacción granulomatosa a cuerpo extraño. Mientras la estructura del scaffold original es degradada, se produce 
la integración de la nueva matriz extracelular producida por células sembradas en el scaffold o provenientes del propio huésped, generándose un nuevo tejido que puede reproducir las funciones del tejido originalmente dañado.

En resumen el scaffold Meana ofrece una serie de ventajas que lo diferencian de otros utilizados previamente (Meana y cols, 2008):

- Aporta una estructura tridimensional para las células, aportando a la vez señales de adhesión. Además permite la neovascularización, favoreciendo la formación del nuevo tejido. Esto confiere al producto, una composición idónea para el desarrollo de modelos de ingeniería tisular.

- Es un scaffold que permite el cultivo "in vitro" durante largos periodos de tiempo (hasta 6 meses), sin pérdida de la estructura tridimensional. Esto permite el desarrollo de modelos de diferenciación "in vitro".

- Es un material biológico actualmente empleado en clínica a través de diferentes ensayos y proyectos de investigación (Redondo y cols, 2010; Gómez y cols, 2011).

- El producto original es de muy fácil obtención a partir de concentrados de albúmina o extracción hemática (venopunción).

- La posibilidad de construir un soporte para ingeniería tisular a partir de pequeñas cantidades de plasma, nos ofrece la posibilidad de obtener estas estructuras partiendo de productos biológicos autólogos, es decir, obtenidos del propio paciente al que va a ser implantados, evitando de esta manera el uso de materiales alogénicos, que pueden llegar a producir rechazo inmunológico en el paciente, así como el rechazo social que algunos en algunos casos provoca. 


\subsection{OBTEOBTENCIÓN DE MSC}

Desde los primeros trabajos de Peck y cols. en la década de los 60, que aislaron y cultivaron células mesnquimales obtenidas a partir de tejido óseo (Peck y cols, 1964), se han descrito distintas técnicas para tal fin como la digestión enzimática con colagenasa (Beresford y cols, 1983; Luben y cols, 1976), la clonación (Aubin y cols, 1982) o el aislamiento mecánico (Gallagher y cols, 1983; Williams y cols, 1980). Una vez establecido el cultivo celular, la caracterización es un procedimiento obligatorio para poder confirmar la presencia, proliferación y diferenciación celular (Shima y cols, 2015). Esta caracterización se basa en la producción de ciertas sustancias asociado a este tipo de células como el colágeno de tipo I (Eyre y cols, 1980), la actividad de la fosfatasa alcalina (Ashton y cols, 1985) y la producción de osteocalcina (Casser-Bette y cols, 1990; Auf'mkolk B, y cols, 1985) y osteonectina, (Whitson y cols, 1984), así como respuesta celular a prostaglnadina E (Luben y cols, 1976; Nijweide y cols, 1982), y la capacidad osteogénica (Whitson y cols, 1984; Casser-Bette y cols, 1990; Majeska y cols, 1985). Por otra parte, la morfología de las células cultivadas, no siempre se diferencian bien de otras células mesenquimales, lo que obliga a llevar a cabo procedimientos bioquímicos y morfológicos de caracterización celular. En nuestro trabajo utilizamos la misma metodología llevada a cabo por la Dra. Gallego quien realizó un estudio histoquímico mediante tinción de Hematoxilina-Eosina que objetivó la presencia de células osteoblásticas. También confirma mediante tinción de Von Kossa la producción de matriz osteoide. La detección de la actividad de fosfatasa alcalina confirmó el fenotipo osteoblástico del cultivo. Por último el análisis mediante microscopía electrónica de barrido muestra la presencia homogénea de células en todo el scaffold, tanto a nivel de superficie como en todo su espesor, así como nódulos de 
calcificación. El uso de microscopía electrónica de barrido como herramienta para el análisis de cultivos celulares de osteoblastos, ha sido estudiado por distintos autores como Malicev y cols. en 2008, y Bassi y cols. en 2015 que estudian la presencia de osteoblastos sembrados sobre hidroxiapatita. En otros trabajos como los de Wagner en 2007, se estudia el comportamiento de osteoblastos humanos sembradas sobre distintas matrices (Wagner y cols, 2007; Zhang y cols, 2015). En todos estos trabajos se observa, gracias al uso de microscopía electrónica de barrido, en mayor o menor medida, la presencia de osteoblastos bien asentados sobre la matriz con la presencia de uniones intercelulares y núcleos de calcificación.

\subsection{ANÁLISIS RADIOLÓGICO.}

Durante muchos años se ha utilizado el estudio de densidades radiológicas para evaluar los procesos de regeneración ósea mediante el empleo de distintos biomateriales. Hasta la década de los 90, mediante el estudio de radiografía convencional, se utilizaban criterios de difícil reproducción basados en escalas de aluminio (Bloxom y cols, 1986), en los que a las distintas radiopacidades se les asignaba un valor numérico de tal manera que pudieran someterse a un estudio estadístico, obteniendo así resultados cuantificables (Kawai y cols, 1988; Lasa y cols, 1995).

Hoy en día, gracias a la evolución tecnológica, disponemos de distintas pruebas radiológicas más fiables, que nos permiten un estudio más preciso. Las tomografías convencionales en dos dimensiones están evolucionando, permitiéndonos obtener reconstrucciones volumétricas en tres dimensiones que se pueden extender a la adquisición de imágenes en cuatro o cinco dimensiones. Estos conceptos de cuarta y quinta dimensión hacen referencia a la capacidad que poseen determinados software de 
procesamiento de imágenes de obtener, a través del uso de la combinación de tomografía computerizada y tomografía por emisión de positrones, así como mediante el detector ultrarrápido de tomografía computerizada cardiaca, información de la actividad metabólica incluso en tiempo real.

En nuestro trabajo obtenemos imágenes de tomografía computerizada en formato DICOM (Digital Imagning and Communications in Medicine) que es el formato de imagen que actualmente se utiliza con más frecuencia. Existen multitud de programas informáticos en el mercado que permiten el tratamiento de dichas imágenes. Nosotros hemos escogido la plataforma OsiriX® compatible con MacOS (Apple $囚)$. Este programa desarrollado a principios de la década de los 2000 en la Universidad de UCLA, presenta la capacidad de realizar reconstrucciones multiplanares o MPR (multiplnar reconstruction), así como visualizaciones tridimensionales mediante proyecciones de máxima intensidad o MIP (Máximum Intensity Projection) (Rosset y cols, 2004; Rosset, y cols, 2006; Rosset, y cols, 2005). Actualmente, OsiriX® está siendo utilizado, en sus últimas verisones, de manera muy extendida en el diagnóstico médico en la práctica clínica habitual.

Uno de los objetivos fundamentales que nos marcamos al inicio de este trabajo, fue conseguir unos protocolos para el estudio de los procesos regenerativos mediante el análisis de las densidades radiológicas de los defectos, para lo cual se pretendió evaluar la densidad mineral ósea (DMO) (Hohlweg-Majert y cols, 2011). En este trabajo medimos la densidad media de un volumen correspondiente al defecto creado a partir de la medición de las densidades medias de las distintas áreas que conforman dicho volumen. En este sentido casi todos los trabajos que hemos encontrado presentan los análisis de densidad radiológica mediante el estudio de las densidades medias de un área determinado; la mayor parte de los trabajos encontrados se refieren al ámbito de la 
cirugía implantológica dental, en la que se pretende diagnosticar las zonas del hueso del paciente, que presenten mayor densidad ósea, para seleccionar las zonas más adecuadas para la colocación de implantes dentales (Homolka y cols, 2002; Aranyarachkul y cols, 2005; Turkiyilmaz y cols, 2007; Meyer, 2009; Hao y cols, 2014).

En otros trabajos como los de Hee Jung Kim y cols. en 2011, centran el estudio de la reparación del defecto acotando el análisis de la densidad radiológica a un área que corresponde al centro de la lesión, obviando los márgenes de la misma y evitando así incluir en el análisis de las densidades radiológicas zonas de hueso intacto del huésped que pudieran modificar, interferir y sesgar los resultados obtenidos.

En distintos trabajos publicados en modelo animal, utilizan testigos radiológicos que se introducen en el animal cerca de las zonas del defecto para poder comparar la atenuación de los rayos sufrida en el interior del defecto con dichos testigos. Consideramos que dichos testigos podrían distorsionar la zona del defecto por su proximidad y además la gran morbilidad que implica utilizar fantomas densitométricos, hecho descartable en cualquier procedimiento de investigación clínica en seres humanos. Otros estudios utilizan la selección arbitraria de distintos puntos dentro del defecto y a partir de éstos calculan la media de densidad de dichos puntos, utilizando dichos valores para la comparativa entre los distintos grupos. Precisamente el hecho de ser seleccionados de forma arbitraria es poco fiable teniendo en cuenta que el proceso de regeneración dentro de un defecto no es uniforme en todos los puntos del defecto.

En otros estudios se analiza la densidad media en volumen (estudios volumétricos), que teóricamente correspondería al defecto y se realiza la comparativa a partir de dichos resultados. Entendemos que en un volumen existen zonas que corresponden al hueso neoformado pero también a zonas con otros tejidos adyacentes al hueso, como músculo, que generarían una media de densidad mucho más baja al considerar todos estos tejidos. 
Nuestro modelo se basa en el que ha sido el gold standard para la medición de la densidad mineral ósea de un volumen a partir de la tomografía computerizada cuantitativa: QCT: quantitative computed tomography (Georgescu y cols, 2010). La QCT permite obtener valores de densidad de un determinado volumen de hueso; en sus inicios utilizaba fantomas de calibración con materiales de distinta densidad que producían una atenuación de la radiación similar a la que produce las distintas densidades de hueso obteniendo así unos valores de densidad mineral ósea específica que podría equipararse a las unidades Housnsfield. Hoy en día, el desarrollo de nuevos programas de análisis de imagen permite el estudio de las densidades en determinadas áreas de interés, pero también gracias a las reconstrucciones volumétricas, en volúmenes donde podemos medir la densidad media.

En nuestro modelo intentamos estudiar un VOI (volumen of interest) determinado que coincida con el tamaño del defecto y que se encuentra situado en el lugar del defecto. Para ello hacemos el estudio en los tres planos del espacio, analizando un ROI (región of interest) de $0,032 \mathrm{~cm}^{2}$ para el plano axial, de $0,032 \mathrm{~cm}^{2}$ para el plano coronal y de $0,125 \mathrm{~cm}^{2}$ para el plano sagital. La mayor dificultad fue situar el área a estudiar en la posición donde teóricamente se encuentra el defecto. No obstante la menor mineralización del hueso neoformado nos permitió determinar el área concreta. Además tomamos valores arbitrarios dentro del defecto para saber que estábamos en la localización precisa y lo comparamos con un valor también arbitrario separado del defecto que nos indicaba siempre una densidad mayor correspondiente a hueso intacto. De este modo teníamos una gran seguridad de escoger el área correcta. Para obtener mediciones fiables se procedió a medir en dos ocasiones cada una de las áreas de interés y se hizo por tres observadores diferentes, sistemática llevada a cabo en numerosos trabajos publicados. No obstante la elección de un $R O I$ determinado para su análisis 
densitométrico radiológico no está exento de la problemática de incluir en él tejidos blandos adyacentes, lo cual falsearía la media de densidad a la baja. Por eso no sería descartable el centrar el estudio a una zona más reducida que el tamaño del defecto creado para incluir en él solamente tejido óseo, intentando acotar la zona de estudio al centro de la lesión (Kim HJ y cols, 2011). 


\section{DISCUSIÓN DE LOS RESULTADOS}

En el trabajo que nos ocupa, hemos llevado a cabo un estudio experimental de regeneración ósea en rata atímica, en el que se pretende analizar las diferencias osteorregenerativas en los defectos críticos mandibulares creados en dichos animales, comparando los distintos grupos establecidos en función del injerto implantado en cada uno de los grupos, estableciendo así los siguientes grupos:

- Grupo I: scaffold con células en medio de expansión durante 1 día ( $S M+$ células 1 día).

- Grupo II: CONTROL: solo scaffold. (SM).

- Grupo III: scaffold con células cultivadas durante 21 días en medio osteogénico (SM+células 21 diferenciadas).

- Grupo IV: scaffold con células cultivadas 21 días en medio no osteogénico ( $S M+$ células 21 días).

Lo primero que hay que analizar, antes de entrar en el análisis de los resultados propiamente dichos, es la variabilidad que existe entre las mediciones realizadas, tanto a nivel interobservador (el grado de concordancia de las mediciones realizadas por dos o más observadores diferentes) como intraobservador (el grado de concordancia de las diferentes mediciones realizadas por el mismo observador). Para ello, hemos utilizado una herramienta estadística que es el coeficiente de variación (CV). Como norma general cuando el coeficiente de variación entre las distintas mediciones es inferior al $10 \%$ se considera preciso, cuando este coeficiente se encuentra en el intervalo entre 10 y $25 \%$ se considera aceptable. Cuando el coeficiente de variación se encuentra por encima del $25 \%$ sólo lo podríamos tomar como tendencia y se considera desechable. En 
nuestro caso, ninguno de los valores medios de los coeficientes de variación supera el $25 \%$. No obstante se observan los coeficientes de variación más elevados en función del área estudiada, lo que nos indica que la reproductibilidad de la metodología de la medición es más sencilla en el área denominado área 1 (corte sagital), que en el área 2 (corte coronal) y encontramos mayor variabilidad en las mediciones en el área 3 (corte axial). Esto es debido a que el posicionamiento del área de estudio en los cortes coronal y axial es más complicado, ya que dicha superficie tiene dimensiones similares al tamaño de la mandíbula en el mismo corte por lo que mínimas variaciones en el posicionamiento del área de estudio generará importantes variaciones en las densidades radiológicas, lo que nos llevaría a incluir en el área de estudio densidad aire fuera del propio hueso mandibular (se están calculando densidades radiológicas medias de áreas correspondientes al tamaño del defecto en cada uno de los planos).

En el estudio ortotópico se produce una mayor regeneración ósea en el grupo III, que en el I y II sin existir diferencias significativas entre ellos. Sin embargo, el grupo IV presentó un menor proceso de regeneración ósea estadísticamente significativo. Estos datos obtenidos a partir del estudio radiológico coinciden con el análisis histológico que se realiza de las muestras, donde en estos tres primeros grupos, a partir del análisis realizado mediante tinción de $\mathrm{H}-\mathrm{E}$, se observan distintas zonas de osificación en mayor o menor medida. Sin embargo, en los pertenecientes al grupo IV apenas se observan células osteoblásticas ni procesos de calcificación, y sí restos de scaffold y gran cantidad de tejido fibroso.

Llama la atención la poca o nula influencia que parece tener el tipo de células que sembramos en el scaffold, hasta el punto de que el scaffold por sí solo genera unos niveles de osteoformación muy similares a cuando se utiliza el scaffold con células cultivadas un día en medio osteogénico o cuando se usa scaffold con células cultivadas 
durante 21 días en medio osteogénico. Estos resultados hay que interpretarlos con cautela, ya que la valoración del proceso regenerativo se lleva a cabo en un momento muy determinado que es la semana número 12, por tanto, con los datos obtenidos a partir de nuestro trabajo, desconocemos cómo serían los procesos de regeneración si hubiéramos realizado el análisis en las primeras semanas y cómo se van igualando dichos procesos regenerativos a medida que va pasando el tiempo. En distintos trabajos publicados, realizan el análisis de regeneración en distintos momentos: en las semanas iniciales $\left(3^{\mathrm{a}}\right.$ o $4^{\mathrm{a}}$ semana) en las que parece que el contenido del scaffold sí es determinante, de manera que el uso de células cultivadas en medio osteogénico sí generaría una diferencia mayor, observando una mayor rapidez en la regeneración al inicio que en un momento intermedio (semana 10 a la 15), en la que se empieza a ver que las diferencias entre los grupos va desapareciendo, y en un momento más tardío, como en la semana 40, en la que se produce una reparación prácticamente completa de ese defecto crítico y por tanto no existen diferencias (Hee Jung Kim y cols, 2011). En nuestro estudio, la reparación del defecto es parcial en todos los casos de los 3 primeros grupos (I, II yIII), pero cabría esperar una regeneración completa del defecto si se concediera más tiempo antes del sacrificio. Este trabajo deja abiertas distintas vías de estudio, como es intentar conocer la diferencia del comportamiento de dichos scaffolds con los distintos contenidos celulares en distintos momentos del tiempo, así como la capacidad osteoinductiva y osteoconductiva de la matriz a lo largo del tiempo. Por tanto, más que el uso de un determinado contenido celular en el interior del scaffold lo que parece realmente determinante es el scaffold en sí mismo, que por sus particularidades estructurales, su composición y su arquitectura tridimensional, parece ofrecer un lugar ideal para permitir el crecimiento celular en su interior, permiteindo que células del huésped aniden en él, lo colonicen y formen el nuevo tejido. 
Sin embargo, hay uno de los cuatro grupos estudiados que presenta unos resultados significativamente menores de regeneración que el resto, que es el grupo IV que es aquel en el que utilizamos como injerto el scaffold con un cultivo celular durante 21 días en medio de expansión no osteogénico. La interpretación que hacemos de este resultado se basa en la potencialidad de las células sembradas en el scaffold, ya que al no favorecer su diferenciación en el cultivo in vitro parece que es influenciado por el ambiente del huésped en donde se produciría una diferenciación hacia linaje fibrablástico, observándose, por tanto, gran cantidad de tejido conectivo laxo en el interior del defecto, apareciendo únicamente pequeñas zonas de tejido óseo inmaduro alejados del centro del defecto, originado por el tejido del huésped en el proceso de reparación de la herida quirúrgica. Pero ¿por qué no se ha producido en este caso una regeneración por lo menos similar a la que observamos en el caso del grupo II (scaffold solo)? Una explicación posible, la atribuimos a la competencia que se establece entre las células del tejido huésped que rodea el defecto, donde parece que ha tenido más fuerza la presencia del tejido fibroso que el tejido óseo a la hora de generar el estímulo necesario para la diferenciación del injerto, coincidiendo con lo publicado por Harris y Cooper en el año 2004.

También el no encontrar diferencias significativas en los tres primeros grupos nos plantea una serie de incógnitas ¿Tiene o no tiene influencia la composición del injerto en la regeneración final, hasta el punto de que el scaffold sin ningún tipo de preparado celular, puede generar una cantidad hueso similar a la obtenida con aquella en la que se ha producido un estímulo para la diferenciación de las células a células óseas (osteoinducción)? Se nos presentan distintas dudas debido al modelo del estudio que hemos establecido, en cuanto a los momentos del análisis de la regeneración, ya que es posible que en las primeras semanas el defecto del grupo I ( $S M+$ células 1 día) y 
especialmente el del grupo III ( $S M+$ células 21 días diferenciadas), podría tener un mayor grado de regeneración que el del grupo II (control), y que a medida que va pasando el tiempo los procesos regenerativos se van igualando. Del mismo modo nos queda la duda de hasta qué punto se produciría el cierre completo del defecto crítico si el análisis se hubiera llevado a cabo en la semana 40 por ejemplo, donde posiblemente el proceso regenerativo podría ser completo en el grupo I o III y no total en el grupo II. No obstante, son dudas que se pueden despejar en futuros estudios que continúen con esta línea de investigación. Ahora bien ¿el tejido óseo neoformado de los grupo I y III es de origen humano, es del propio animal o es una mezcla de ambos? No podemos contestar a esta pregunta ya que no se ha podido realizar un estudio inmunohistoquímico (expresión de la Vimentina Humana) a las distintas muestras por limitaciones de orden fundamentalmente económicas. En distintos trabajos, como el publicado por Chen y cols. en el año 2002, se plantea la duda de si el tejido óseo formado procede de las células donantes, o de las propias células del huésped sometidas a un proceso de osteoinducción por parte de las primeras. Para averiguarlo, en distintos trabajos publicados en la literatura se procede al marcaje de las células mesenquimales implantadas o se realiza el estudio de la expresión de genes osteoblásticos, demostrando que son las células donantes las que mayor responsabilidad adquieren en el proceso de regeneración ósea, secretando factores inductivos que atraen células del huésped promoviendo su diferenciación osteogénica (Lee y cols 2000; Cowan y cols 2004). En el trabajo iniciado por la Dra. Gallego, planteaba la comparativa del uso de un scaffold con células sembradas de origen humano en defectos críticos vs esos mismos defectos sin ningún tipo de scaffold, donde demostró una mayor regeneración en los injertos donde se había utilizado matriz (Gallego y cols, 2010). En dicho trabajo se pudo identificar el origen del hueso neoformado mediante la expresión de la Vimentina 
Humana, demostrando la presencia de células humanas en el scaffold. Precisamente un objetivo secundario que nos marcamos en este estudio fue el estudio satélite de estos mismos injertos localizados en una ubicación fuera de la mandíbula y alejado de cualquier componente óseo que pudiera influir en la formación ósea dentro del scaffold. De los cuatro grupos estudiados solamente se observó tejido óseo en los pertenecientes al grupo III (scaffold con células cultivadas durante 21 días en medio osteogénico), además la cantidad de tejido óseo formado era significativamente menor al encontrado en el estudio ortotópico mandibular. A partir de esta situación interpretamos que aunque el scaffold es capaz de estabilizar las células previamente cultivadas, y que en este caso, la diferenciación generada previa a la implantación del injerto es capaz de generar crecimiento óseo con células de origen humano, lo verdaderamente influyente es el uso de una matriz con unas características muy concretas que favorecen el crecimiento óseo. En el estudio de la Dra. Gallego no se evaluó el grado de influencia de la matriz en si misma en el proceso regenerativo. En nuestro estudio hemos observado, gracias al estudio satélite a nivel inguinal, que la matriz es capaz de favorecer la osteoformación de tejido óseo humano y no perteneciente al huésped al usar los injertos con cultivo celular de 21 días en medio osteogénico, pero que cuando el scaffold no contiene ningún preparado celular, es capaz de llevar a cabo una regeneración ósea similar a cuando contiene células diferenciadas (cuando se analizan los procesos regenerativos en la semana 12) cuando es injertado, lógicamente, en un defecto en el propio hueso. Otra característica muy importante que hemos podido confirmar es la capacidad que presenta el scaffold para favorecer la neovascularización, gracias a que el tamaño del poro utilizado en este scaffold permite el crecimiento de elementos vasculares en el interior del injerto, como hemos podido confirmar en el estudio heterotópico mediante el análisis histológico de los grupos I y II, mediante 
tinción de Giemsa y H-E, que si bien en estos grupos no se ha producido un crecimiento óseo, tiene gran relevancia el hallazgo de esos componentes vasculares, fundamentales para la viabilidad del injerto a largo plazo. Por lo que parece que lo más influyente a la hora de producirse la regeneración del defecto es la propia matriz, que por sus características la convierten en un lugar muy favorable para la migración, asentamiento y crecimiento de las células óseas, así como un lugar favorecedor de la neovascularización del injerto.

Existe cierta controversia en cuanto a las ventajas del uso de células diferenciadas total o parcialmente hacia el linaje osteoblástico respecto al uso de células no diferenciadas. Distintos estudios apuntan la necesidad de utilizar células indiferenciadas para que tras su implantación no sólo evolucionen hacia la estirpe osteoblástica, sino que lo haga también hacia la estirpe endotelial favoreciendo de este modo el proceso de angiogénesis, fundamental para favorecer la regeneración ósea (Silva y cols. 2005; Trabanelli y cols, 2015), de este modo los procesos de angiogénesis y osteogénesis se pueden ver mutuamente beneficiados al utilizar células en este estado de indiferenciación. Otros estudios como los realizadas en calota de conejo por Dudas y cols, 2006 o fémur de conejo por Peterson y cols, 2005 y Yoon y cols, 2007 observaron que las células sometidas a osteoinducción presentaban una mayor actividad reparativa en comparación con las células no diferenciadas. Otros estudios como los de Van der Doder y cols. 2003, llegan a una situación intermedia en la que consideran que lo ideal es aprovechar las ventajas de los dos tipos de células (diferenciadas previamente y no diferenciadas) realizando un cultivo celular en medio osteogénico de forma rápida y transitoria. 
El scaffold utilizado en nuestro trabajo es una herramienta muy prometedora en los procedimientos de Ingeniería Tisular Ósea (ITO) para la reparación de determinados defectos críticos en el hueso. Sus propiedades osteoinductivas y osteoconductivas, sus características estructurales, mecánicas, de biocompatibilidad y biodegradabilidad, así como la facilidad de obtención a partir del propio paciente, lo convierten en una alternativa muy importante a la hora de escoger la matriz más apropiada para ser utilizada en los procesos de regeneración ósea. No obstante, aunque el scaffold es un pilar básico en ITO, es muy importante encontrar un equilibro eadecuado entre el resto de los pilares que conformarn las estrategias de ingeniería tisular como son las células y las moléclulas de señalización especfíficas. Es por ello que todos los esfuerzos deben ir dirigdos al perfeccionamiento de los biomateriales utilizados, el desarrollo de nuevos sitemas de biorreactores, que permitan reproducir in vitro condiciones microambientales lo más parecidas posibles al tejido óseo in vivo, desarrollando nuevos métodos de neovascularización así como la obtención de fuentes seguras de células osteogénicas, aplicando todos estos avances a los requerimientos específicos de cada enfermedad. Además, otro objetivo muy importante es el desarrollo de nuevas estrategias de evaluación de los procesos osteorregenerativos mediante métodos no invasivos de obtención de imágenes y su posterior interpretación. Nosotros presentamos en nuestro trabajo un método novedoso para poder cuantificar los procesos de regeneración ósea, obteniendo resultados fiables y reproducibles. No obstante esta metodología necesita ser perfeccionada y contrastada en futuros trabajos que continúen en esta línea de investigación. 


\section{CONCLUSIONES}



Las conclusiones obtenidas de nuestro estudio son las que procedo a enumerar a continuación:

1. Tanto histológicamente como radiológicamente existe evidencia de formación ósea, sin que se halla producido la regeneración completa de los defectos óseos creados. Posiblemente 12 semanas sean insuficientes para completar un proceso de regeneración ósea.

2. La presencia de células osteoblásticas en el injerto, en comparación a la no presencia de células, parece no tener influencia en el proceso de regeneración ósea en la semana 12. La presencia de células no diferenciadas en el injerto sí puede influir negativamente en la formación ósea al poderse diferenciar en la dirección de distintos linajes celulares no deseados.

3. El scaffold, por sus características estructurales y químicas, favorece la migración, asentamiento y crecimiento de las células óseas.

4. El scaffold reúne una serie de condiciones que permite el cultivo celular in vitro y su posterior implantación en el huésped, favoreciendo el crecimiento celular, la neovascularización del injerto y la consiguiente formación de tejido óseo.

5. Los injertos con células diferenciadas durante 21 días en medio osteogénico implantadas en la región inguinal de ratas atímicas, evidenció formación ósea, con algunos núcleos de mineralización, evaluado a las 12 semanas pos-injerto. 
6. La metodología que hemos establecido en este estudio para medir la regeneración ósea a través de las densidades radiológicas es fiable y reproducible, aunque necesitará ser contrastada en futuros estudios. 


\section{BIBLIOGRAFÍA}



1. Aaron RK, Ciombor DM. Acceleration of experimental endochondral ossification by biophysical stimulation of the progenitor cell pool. J Orthop Res. 1996;14:582-9.

2. Abukawa H, Papadaki M, Abulikemu M, Leaf J, Vacanti JP, Kaban LB, Troulis MJ. The engineering of craniofacial tissues in the laboratory: a review of biomaterials for scaffolds and implant coatings.Dent Clin North Am. 2006 Apr;50(2):205-16.

3. Agrawal, C.M., Ray, R.B., "Biodegradable polymeric scaffolds for musculoskeletal tissue engineering”, J. Biomed. Mat. Res. 2001; 55:2, 141150.

4. Alkhalil M, Smajilagić A, Redžić A Human dental pulp mesenchymal stem cells isolation and osteoblast differentiation. Med Glas (Zenica). 2015 Feb;12(1):27-32.

5. Altankov G, Thom V, Groth T, Jankova K, Jonsson G, Ulbricht M. Modulating the biocompatibility of polymer surfaces with poly(ethylene glycol): effect of fibronectin. J Biomed Mater Res. 2000 Oct;52(1):219-30.

6. Amirkhosravi, A., Meyer, T., Warnes, G., Amaya, M., Malik Z, Biggerstaff, J.P., et al. (1998). Pentoxifylline inhibits hypoxia-induced upregulation of tumor cell tissue factor and vascular endotelial growth factor. Thromb. Haemost, 80, 598-602.

7. Aranyarachkul P, Caruso J, Gantes B, Schulz E, Riggs M, Dus I, Yamada JM, Crigger M. Bone density assessments of dental implant sites: 2. Quantitative cone-beam computerized tomography. Int J Oral Maxillofac Implants. 2005 May-Jun;20(3):416-24.

8. Asahara T, Kawamoto A. Endothelial progenitor cells for postnatal vasculogenesis. Am J Physiol Cell Physiol. 2004 Sep;287(3):C572-9.

9. Ashton BA, Abdullah F, Cave J, Williamson M, Sykes BC, Couch M et al. Characterization of cells with high alkaline phosphatase activity derived from human bone and marrow: preliminary assesment of their osteogenicity. Bone 1985: 6: 313- 9 .

10. Ashton BA, Allen TD, Howlett CR, Eaglesom CC, Hattori A, Owen M. Formation of bone and cartilage by marrow stromal cells in diffusion chambers in vivo. Clin Orthop Relat Res. 1980 Sep;(151):294-307.

11. Assinelli, C., Morra, M., Bruzzone, G., Carpi, A., Di Santi, G., Giardino, R., Fini, M., "Surface chemistry effects of topographic modification of titanium dental implant surfaces: 1. Surface analysis", Int. J. Oral \& Maxillofac. Impl. 2003; 18:1, 46-50.

12. Assmus B, Schächinger V, Teupe C, Britten M, Lehmann R, Döbert N, Grünwald F, Aicher A, Urbich C, Martin H, Hoelzer D, Dimmeler S, Zeiher AM. Transplantation of Progenitor Cells and Regeneration Enhancement in Acute Myocardial Infarction (TOPCARE-AMI). Circulation. 2002 Dec 10;106(24):3009-17.

13. Association, A.V.M., AVMA Guidelines on Euthanasia. 2007. 
14. Aubin JE, Bonnelye E. Osteoprotegerin and its ligand: A new paradigm for regulation of osteoclastogénesis and bone resorption. Osteopros Int. 2000; 11(11):905-13.

15. Aubin JE, Heersche JNM, Merrilees MJ, Sodek J. Isolation of bone cell clones with differences in growth, hormone respon- ses, and extracellular matrix production. J Cell Biol 1982; 92: 456-61.

16. Aubin JE, Liu F. The osteoblasts lineage. En: Bilezikian JP, Raisz LG, Rodan GA, eds. Principles of Bone Biology. San Diego, California: Academic Press;1996. p. 51-67.

17. Aubin JE. Advances in the osteoblast lineage. Biochem Cell Biol. 1998; 76:899-910.

18. Aufmkolk B, Hauschka PV, Schwartz ER. Characterization of human bone cells in culture. Calcif Tissue Int 1985; 37: 228- 35.

19. Azizi SA, Krynska B. Derivation of neuronal cells from fetal normal human astrocytes (NHA). Methods Mol Biol. 2013;1078:89-96.

20. Bancroft GN, Mikos AG. In: Ikada Y, Ohshima N, editores. Tissue Engineering for Therapeutic Use. $5^{\mathrm{a}}$ ed. Amsterdam: Elservier; 2001. Pp. 15163.

21. Baron R. Anatomy and Biology of Bone Matrix and Cellular Elements. Chapter 1. General Principles of Bone Biology. Primer on the metabolic bone diseases and disorders of mineral metabolism, fifth ed. 2003. American society for bone and mineral researche, Washington, DC. Pp 1-8.

22. Barone A, Aldini NN, Fini M, Giardino R, Calvo Guirado JL, Covani U. Xenograft versus extraction alone for ridge preservation after tooth removal: a clinical and histomorphometric study. J Periodontol. 2008 Aug;79(8):1370-7.

23. Barrett R, Ornelas L, Yeager N, Mandefro B, Sahabian A, Lenaeus L, Targan SR, Svendsen CN, Sareen D. Reliable generation of induced pluripotent stem cells from human lymphoblastoid cell lines. Stem Cells Transl Med. 2014 Dec;3(12):1429-34.

24. Bassi G, Guilloton F, Menard C, Di Trapani M, Deschaseaux F, Sensebé L, Schrezenmeier H, Giordano R, Bourin P, Dominici M, Tarte K, Krampera M. Effects of a ceramic biomaterial on immune modulatory properties and differentiation potential of human mesenchymal stromal cells of different origin. Tissue Eng Part A. 2015 Feb;21(3-4):767-81.

25. Bauer TW, Muschler GF. Bone graft materials. An over- view of the basic science. Clin Orthop 2000; 371:10-27.

26. Bäuerle, T., Peterschmitt, J., Hilbig, H., Kiessling, F., Armbruster, F.P., and Berger, M.R. (2006). Treatment of bone metástasis induced by MDA-MB-231 breast cancer cells with an antibody against bone sialoprotein. Intl. J. Oncol., $28,573-83$.

27. Becerra J, Andrades JA, Santamaría JA, Cifuentes M, Guerado E. Bone regeneration, cell therapy and tissue engineering].Med Clin (Barc). 2001 Jan 13;116(1):23-34.

28. Behairy Y, Jasty M. Bone grafts and bone substitutes in hip and knee surgery. 
Orthop Clin North Am 1999;30:661-71.

29. Bergsma JE, de Bruijn WC, Rozema FR, Bos RR, Boering G. Late degradation tissue response to poly(L-lactide) bone plates and screws. Biomaterials. 1995 Jan;16(1):25-31.

30. Berridge MV, O'Kech N, McNeilage LJ, Heslop BF, Moore R. Rat mutant (NZNU) showing "nude" characteristics. Transplantation. 1979 Jun;27(6):4103.

31. Bhatia M. AC133 expression in human stem cells. Leukemia. 2001 Nov;15(11):1685-8.

32. Bittira B, Kuang JQ, Al-Khaldi A, Shum-Tim D, Chiu RC. In vitro preprogramming of marrow stromal cells for myocardial regeneration. Ann Thorac Surg. 2002;74:1154-60.

33. Blau HM, Brazelton TR, Weimann JM. The evolving concept of a stem cell: entity or function? Cell. 2001 Jun 29;105(7):829-41.

34. Block, Michael S ; Kent, John N. Sinus augmentation for dental implants: The use of autogenous bone. Journal of Oral and Maxillofacial Surgery, 1997, Vol.55(11), pp.1281-1286.

35. Blocklet D, Toungouz M, Berkenboom G, Lambermont M, Unger P, Preumont N, Stoupel E, Egrise D, Degaute JP, Goldman M, Goldman S. Myocardial homing of nonmobilized peripheral-blood CD34+ cells after intracoronary injection. Stem Cells. 2006 Feb;24(2):333-6.

36. Bloom, Fawcett. Textbook of histology. En: Chpmen, Hall, editores. 12 ed. 1994; 194-224.

37. Bloxom Rm, Manson-Hing Lr. The Accuaracy Of An X-Ray Film QualityAssurance Step-Edge Test. Oral Surg Oral Med Oral Pathol 1986; 62: 449-58.

38. Boden SD, Kang J, Sandhu H, Heller JG. Use of recombinant human bone morphogenetic protein-2 to achieve posterolateral lumbar spine fusion in humans: a prospective, randomized clinical pilot trial: 2002 Volvo Award in clinical studies. Spine (Phila Pa 1976). 2002 Dec 1;27(23):2662-73.

39. Bolander ME, Balian G. The use of demineralized bone matrix in the repair of segmental defects. Augmentation with extracted matrix proteins and a comparison with autologous grafts. J Bone Joint Surg [Am] 1986; 68: 12641274.

40. Boquest AC, Day BN, Prather RS. Flow cytometric cell cycle analysis of cultured porcine fetal fibroblast cells. Biol Reprod. 1999 Apr;60(4):1013-9.

41. Bosch P, Musgrave D, Ghivizzani S, Latterman C, Day CS, Huard J. The efficiency of muscle-derived cell-mediated bone formation. Cell Transplant. 2000;9:463-70.

42. Bosch P, Musgrave DS, Lee JY, Cummins J, Shuler T, Ghivizzani TC, Evans T, Robbins TD, Huard J. Osteoprogenitor cells within skeletal muscle. J Orthop Res. 2000;18:933-44.

43. Böstman O, Hirvensalo E, Mäkinen J, Rokkanen P. Foreign-body reactions to fracture fixation implants of biodegradable synthetic polymers. J Bone Joint Surg Br. 1990;72:592-6. 
44. Böstman $O$, Hirvensalo E, Vainionpää S, Vihtonen K, Tórmälä P, Rokkanen $P$. Degradable polyglycolide rods for the internal fixation of displaced bimalleolar fractures. Int Orthop. 1990;14(1):1-8.

45. Boyce T, Edwards J, Scarborough N. Allograft bone. The influence of processing on Safety and performance. Orthop Clin North Am 1999; 30:57181.

46. Boyne PJ, James RA. Grafting of the maxillary sinus floor with autogenous marrow and bone. J Oral Surg. 1980 Aug;38(8):613-6.

47. Boyne PJ, Nath R, Nakamura A. Human recombinant BMP-2 in osseous reconstruction of simulated cleft palate defects. Br J Oral Maxillofac Surg 1998;36:84-90.

48. Boyne PJ. Animal studies of the application of rhBMP-2 in maxilofacial reconstruction. Bone 1996;19 (Suppl):83S-92S.

49. Bradley JA, Sarawar SR, Porteous C, Wood PJ, Cård S, Ager A, Bolton EM, Bell EB. Allograft rejection in CD4+ T cell-reconstituted athymic nude ratsthe nonessential role of host-derived CD8+ cells. Transplantation. 1992 Feb;53(2):477-82.

50. Brekke JH. A rationale for delivery of osteoinductive proteins.Tissue Eng. 1996 Summer;2(2):97-114.

51. Bresford J, Gallagher J, Gowen $\mathrm{M}$ el al. Human bone cells in culture: a novel system for the investigation of bone cell meta- bolism. Cli Sci 1983; 64: 33-42.

52. Brighton CT, Lorich DG, Kupcha R, Reilly TM, Jones AR, Woodbury RA 2nd. The pericyte as a possible osteoblast progenitor cell. Clin Orthop. 1992;275:287-99.

53. Brighton CT, Wang W, Seldes R, Zhang G, Pollack SR. Signal transduction in electrically stimulated bone cells. J Bone Joint Surg Am. 2001;83: 1514-23.

54. Brooks CG, Webb PJ, Robins RA, Robinson G, Baldwin RW, Festing MF. Studies on the immunobiology of $\mathrm{rnu} / \mathrm{rnu}$ "nude" rats with congenital aplasia of the thymus. Eur J Immunol. 1980 Jan;10(1):58-65.

55. Bruder SP, Fox BS. Tissue engineering of bone. Cell based strategies. Clin Orthop. 1999;367 Suppl:S68-83.

56. Burch, S., Bogaards, A., Siewerdsen, J., Moseley, D., Yee, A., Finkelstein, J., et al. (2005). Photodynamic therapy for the treatment of metastatic lesions in bone: Studies in rat and porcine models. Journal of Biomedical Optics, 10, 034011-1-13.

57. Burchardt H. The biology of bone graft repair. Clin Orthop 1983;42:28-42.

58. Burg, K.J., Porter, S., Kellam, J.F., "Biomaterial developments for bone tissue engineering Biomaterials". 2000; 21:23, 2347-2359.

59. Burwell RG. Studies in the transplantation of bone. 8. Treated composite homograft-autografts of cancellous bone: an analysis of inductive mechanisms in bone transplantation. J Bone Joint Surg Br. 1966;48:532-66.

60. Burwell RG. The fate of bone graft. In: Apley AG, editor. Recent advances in orthopaedics. London: Williams and Wilkins; 1969. p 115-207. 
61. Buursma, A.R., Beerens, A.M.J., de Vries, E.F.J., van Waarde, A., Rots, M.G., Hospers, G.A.P. et al. (2005). The human norepinephrine transporter in combination with $11 \mathrm{C}$-m-Hydroxyephedrine as a reporter gene/reporter probe for PET of gene therapy. J. Nucl. Med., 46, 2068-75.

62. Cabrera, G., Porvasnik, S.L., DiCorleto, P.E., Siemionow, M. And Goldman, C.K. (2006). Intra-arterial adenoviral mediated tumor transfection in a novel model of cancer gene therapy. Mol. Cancer, 5, 32.

63. Canalis E, Economides AN, Gazzerro E. Bone morphogenetic proteins, their antagonists, and the skeleton. Endocr Rev. 2003 Apr;24(2):218-35.

64. Cancedda R, Bianchi G, Derubeis A, Quarto R. Cell therapy for bone disease: a review of current status. Stem Cells. 2003;21(5):610-9.

65. Cancedda R, Mastrogiacomo M, Bianchi G, Derubeis A, Muraglia A, Quarto R. Bone marrow stromal cells and their use in regenerating bone. Novartis Found Symp. 2003;249:133-43; discussion 143-7, 170-4, 239-41.

66. Canfield AE, Doherty MJ, Ashton BA. Osteogenic potential of vascular pericytes. En: Davies JE ed. Bone Engineering. Toronto: Davies JE ed.; 2000. p. 143-51.

67. Canosa Sevillano, Pérez Blanco R. Diferentes alternati- vas de reconstrucción, biológicas y con biomateriales, de los defectos óseos. Rev Ortop Traumatol 1992; 36IB:128-34.

68. Caplan AI, Bruder SP. Mesenchymal stem cells: building blocks for molecular medicine in the 21st century. Trends Mol Med. 2001;7:259-64.

69. Caplan AI, Goldberg VM. Principles of tissue engineered regeneration of skeletal tissues. Clin Orthop Relat Res. 1999 Oct;(367 Suppl):S12-6.

70. Caplan AI. Mesenchymal stem cells. J Orthop Res. 1991;9:641-50.

71. Carter DR, Beaupre GS, Giori NJ, Helms JA. Mechanobiology of skeletal regeneration. Clin Orthop. 1998;355 Suppl:S41-55.

72. Casser-Bette M, Murray AB, Closs EI, Erfle V, Schmidt J. Bone formation by osteoblast-like cells in a three-dimensional cell culture. Calcif Tissue Int 1990; 46: 46-56.

73. Chapel A, Bertho JM, Bensidhoum M, Fouillard L, Young RG, Frick J, Demarquay C, Cuvelier F, Mathieu E, Trompier F, Dudoignon N, Germain C, Mazurier C, Aigueperse J, Borneman J, Gorin NC, Gourmelon P, Thierry D. Mesenchymal stem cells home to injured tissues when co-infused with hematopoietic cells to treat a radiation-induced multi-organ failure syndrome. $\mathrm{J}$ Gene Med. 2003 Dec;5(12):1028-38.

74. Chen S, Fang W, Ye F, Liu Y, Quian J, Shan S. Effect on left ventricular function of intracoronary transplantation of autologous bone marrow mesenchymal stem cell in patients with acute myocardial infarction. Am J Cardiol 2004;94:92-5.

75. Chen Y, Cheung KM, Kung HF, Leong JC, Lu WW, Luk KD. In vivo new bone formation by direct transfer of adenoviral-mediated bone morphogenetic protein-4 gene. Biochem Biophys Res Commun. 2002 Oct 18;298(1):121-7.

76. Chen Y., Douglass, T., Jeffes, E.W.B., Xu, Q., Williams, C.C., Arpajirakul, N. 
Living T9 glioma cells expressing membrane macrophage colonystimulatingfactor produce immediate tumor destruction by polymorphonuclear leukocytes and macrophages via a "paraptosis"-induced pathway that promotes systemic immunity against intracranial T9 gliomas. Blood, 2002; 100, 1373-80.

77. Civitelli R, Beyer EC, Warlow PM, Robertson AJ, Geist ST, Steinberg TH. Conexin 43 mediates direct intercellular communication in human osteoblastic cells networks. J Clin Invest 1993;91:1888-96.

78. Close B, Banister K, Baumans V, Bernoth EM, Bromage N, Bunyan J, Erhardt W, Flecknell P, Gregory N, Hackbarth $\mathrm{H}$, Morton D, Warwick C. Recommendations for euthanasia of experimental animals: Part 2. DGXT of the European Commission. Lab Anim. 1997 Jan;31(1):1-32.

79. Close B, Banister K, Baumans V, Bernoth EM, Bromage N, Bunyan J, Erhardt W, Flecknell P, Gregory N, Hackbarth H, Morton D, Warwick C. Recommendations for euthanasia of experimental animals: Part 1. DGXI of the European Commission. Lab Anim. 1996 Oct;30(4):293-316.

80. Collas P, Le Guellec K, Taskén K. The A-kinase-anchoring protein AKAP95 is a multivalent protein with a key role in chromatin condensation at mitosis. $\mathrm{J}$ Cell Biol. 1999 Dec 13;147(6):1167-80.

81. Connolly J, Guse R, Lippiello L, Dehne R. Development of an osteogenic bone-marrow preparation. J Bone Joint Surg Am. 1989;71:684-91.

82. Connolly JF, Guse R, Tiedeman J, Dehne R. Autologous marrow injection as a substitute for operative grafting of tibial nonunions. Clin Orthop. 1991; 266:259-70.

83. Connolly JF, Guse R, Tiedeman J, Dehne R. Autologous marrow injection for delayed unions of the tibia: a preliminary report. J Orthop Trauma. 1989; 3:276-82.

84. Cook, J.L., Iklé, D.N. and Routes, B.A. (1995). Natural killer cell ontogeny in the athymic rat. Journal of Immunology, 155, 5512- 8.

85. Cowan CM, Shi YY, Aalami OO, Chou YF, Mari C, Thomas R, Quarto N, Contag $\mathrm{CH}, \mathrm{Wu} \mathrm{B}$, Longaker MT. Adipose-derived adult stromal cells heal critical-size mouse calvarial defects. Nat Biotechnol. 2004 May;22(5):560-7. Epub 2004 Apr 11.

86. D, Kajstura J, Chimenti S, Jakoniuk I, Anderson SM, Li B, Pickel J, McKay R, Nadal-Ginard B, Bodine DM, Leri A, Anversa P. Bone marrow cells regenerate infarcted myocardium. Nature. 2001 Apr 5;410(6829):701-5.

87. D'Ippolito G, Schiller PC, Ricordi C, Roos BA, Howard GA. Age-related osteogenic potential of mesenchymal stromal stem cells from human vertebral bone marrow. J Bone Miner Res. 1999;14:1115-22.

88. Damien CJ, Parson JR, Prewett AB, Rietveld DC, Zimmerman MC. Investigation of an organic delivery System for demineralized bone matrix in a delayed-healing cranial defect model. J Biomed Mat Res 1994; 28: 553-61.

89. Dauchy, R. T., Dauchy, E. M., Sauer, L. A., Blask, D. E., Davidson, L. K., Krause, J. A., et al. (2004). Differential inhibition of fatty acid transport in tissue-isolated steroid receptor negative human breast cancer xenografts perfused in situ with isomers of conjugated linoleic acid. Cancer Letters, 209, 
$7-15$.

90. De Santis R, Russo A, Gloria A, D'Amora U, Russo T, Panseri S, Sandri M, Tampieri A, Marcacci M, Dediu VA, Wilde CJ, Ambrosio L. Towards the Design of 3D Fiber-Deposited Poly( $\varepsilon$-caprolactone)/lron-Doped Hydroxyapatite Nanocomposite Magnetic Scaffolds for Bone Regeneration. J Biomed Nanotechnol. 2015 Jul;11(7):1236-46.

91. De Ugarte DA, Morizono K, Elbarbary A, Alfonso Z, Zuk PA, Zhu M, Dragoo JL, Ashjian P, Thomas B, Benhaim P, Chen I, Fraser J, Hedrick MH. Comparison of multi-lineage cells from human adipose tissue and bone marrow. Cells Tissues Organs. 2003;174:101-9.

92. Dennis JE, Caplan AI.Porous ceramic vehicles for rat-marrow-derived (Rattus norvegicus) osteogenic cell delivery: effects of pre-treatment with fibronectin or laminin. J Oral Implantol. 1993;19(2):106-15; discussion 136-7.

93. Dennis JE, Merriam A, Awadallah A, Yoo JU, Johnstone B, Caplan AI. A quadripotential mesenchymal progenitor cell isolated from the marrow of an adult mouse. J Bone Miner Res. 1999 May;14(5):700-9.

94. Dimitriou R, Mataliotakis GI, Angoules AG, Kanakaris NK, Giannoudis PV. Complications following autologous bone graft harvesting from the iliac crest and using the RIA: a systematic review. Injury. 2011 Sep;42 Suppl 2:S3-15.

95. Dominici M, Le Blanc K, Mueller I, Slaper-Cortenbach I, Marini F, Krause D, Deans R, Keating A, Prockop Dj, Horwitz E. Minimal criteria for defining multipotent mesenchymal stromal cells. The International Society for Cellular Therapy position statement. Cytotherapy. 2006;8(4):315-7.

96. Drobny GP, Long JR, Karlsson T, Shaw W, Popham J, Oyler N, Bower P, Stringer J, Gregory D, Mehta M, Stayton PS. Structural studies of biomaterials using double-quantum solid-state NMR spectroscopy. Annu Rev Phys Chem. 2003;54:531-71.

97. Drosse I, Volkmer E, Capanna R, De Biase P, Mutschler W, Schieker M. Tissue engineering for bone defect healing: an update on a multi-component approach.Injury. 2008 Sep;39 Suppl 2:S9-20.

98. Drosse I, Volkmer E, Seitz S, Seitz H, Penzkofer R, Zahn K, Matis U, Mutschler W, Augat P, Schieker M. Validation of a femoral critical size defect model for orthotopic evaluation of bone healing: a biomechanical, veterinary and trauma surgical perspective. Tissue Eng Part C Methods. 2008 Mar;14(1):79-88.

99. Ducy P, Zhang R, Geoffroy V, Ridall AL, Karsenty G. Osf2/Cbfa1: a transcriptional activator of osteoblast differentation. Cell. 1997 May 30;89(5):747-54.

100.Dudas JR, Marra KG, Cooper GM, Penascino VM, Mooney MP, Jiang S, Rubin JP, Losee JE. The osteogenic potential of adipose-derived stem cells for the repair of rabbit calvarial defects. Ann Plast Surg. 2006 May;56(5):543-8.

101. Eggers $\mathrm{CH}$, Meeder PJ. Biological principles of autogenous bone grafting. Injury 1994; 25: 17-21.

102. Estrada C, Paz A, López L. Ingeniería de tejido óseo: consideraciones básicas. EIA 2006; 5: 93-100. 
103. Evans MJ, Kaufman MH. Establishment in culture of pluripotential cells from mouse embryos. Nature. 1981 Jul 9;292(5819):154-6.

104. Eyre DS. Collagen: molecular diversity in the body's protein scaffold. Science 1980; 207: 15-22. Miller EJ. Collagen chemistry. In Piez, KAS (Ed), Extracellular matrix biochemistry. Amnsterdam: Elsevier 1984; pg.: 41-89.

105. Ferrari G, Cusella-De Angelis G, Coletta M, Paolucci E, Stornaiuolo A, Cossu G, Mavilio F. Muscle regeneration by bone marrow-derived myogenic progenitors.Science. 1998 Mar 6;279(5356):1528-30.

106. Festing MFW, May D, Connors TA, Lovell, D and Sparrow, S. An athymic nude mutation in the rat. Nature, 1978; 274, 5669, 365-6.

107. Fleming JE Jr, Cornell CN, Muschler GF. Bone cells and matrices in orthopedic tissue engineering. Orthop Clin North Am. 2000;31:357-74.

108. Fliedner TM. The role of blood stem cells in hematopoietic cell renewal. Stem Cells. 1998;16(6):361-74.

109. Fodor WL. Tissue engineering and cell based therapies, from the bench to the clinic: the potential to replace, repair and regenerate. Reprod Biol Endocrinol. 2003 Nov 13;1:102.

110. Ford WL, Sparshott SM, Rolstad B. Do nude rats display any alloaggresston? Transplant Proc, 1983; 15:1658-59.

111. Fossum S, Smith ME, Bell EB, Ford WL. The architecture of rat lymph nodes. III. The lymph nodes and lymph-borne cells of the congenitally athymic nude rat (rnu). Scand J Immunol. 1980;12(5):421-32.

112. Freed, L.E., Vunjak-Novakovic, G. Culture of organized cell communities. Adv. Drug. Deliv. Rev. 1998; 33:1-2 15-30.

113. Friedenstein AJ, Petrakova KV, Kurolesova AI, Frolova GP. Heterotopic of bone marrow. Analysis of precursor cells for osteogenic and hematopoietic tissues. Transplantation. 1968 Mar;6(2):230-47.

114. Friedstein AJ. Determined and inducible osteogenic precursor cells. En: Elliott K, Fitzsimmons DW (eds): Hard tissue growth, repair and remineralization. Ciba Fundation Symposium $\mathrm{N}^{\mathrm{o}}$ 11. Amsterdam, Associated Scientific Publisheres, 1973: 169.

115. Friedstein AJ. Gorskaja J, Kulagina N. Fibroblast precursors in normal and irradiated mouse hematopoietic organs. Exp Hematol , 1976; 4:267-74.

116. Fuchs E, Tumbar T, Guasch G. -Socializing with the neighbors: stem cells and their niche. Cell. 2004 Mar 19;116(6):769-78.

117. Gallagher JA, Beresford JN, Sharrard M, Gowen M, Foser J, MacDonald BR et al. Human bone cells in culture. A novel system for the investigation of osteoblast function. Calcif Tissue Int 1983; 35 (Suppl), A24.

118. Gallea S, Lallemand F, Atfi A, Rawadi G, Ramez V, Spinella-Jaegle S, Kawai S, Faucheu C, Huet L, Baron R, Roman-Roman S. Activation of mitogenactivated protein kinase cascades is involved in regulation of bone morphogenetic protein-2-induced osteoblast differentiation in pluripotent C2C12 cells. Bone. 2001 May;28(5):491-8. 
119. Gallego L, Junquera L, Meana A, Alvarez-Viejo M, Fresno M. Ectopic bone formation from mandibular osteoblasts cultured in a novel human serumderived albumin scaffold. J Biomater Appl. 2010 Nov;25(4):367-81.

120. Gallego L, Junquera L, Meana A, García E, García V. Three-dimensional culture of mandibular human osteoblasts on a novel albumin scaffold: growth, proliferation, and differentiation potential in vitro. Int $\mathrm{J}$ Oral Maxillofac Implants. 2010 Jul-Aug;25(4):699-705.

121. Gallego, L, Junquera L, García E, García V, Alvarez-Viejo M, Costilla S, Fresno MF, Meana A. Repair of rat mandibular bone defects by alveolar osteoblasts in a novel plasma-derived albumin scaffold. Tissue Eng Part A, 2010. 16(4): p. 1179-87.

122. Garbuz, Donald S. ; Penner, Murray J. Role and results of segmental allografts for acetabular segmental bone deficiency. Orthopedic Clinics of North America, 1998, Vol.29(2), pp.263-275.

123. Garg NK, Gaur S, Sharma S. Percutaneous autogenous bone marrow grafting in 20 cases of ununited fracture. Acta Orthop Scand. 1993;64:671-2.

124. Garg NK, Gaur S. Percutaneous autogenous bone-marrow grafting in congenital tibial pseudarthrosis. J Bone Joint Surg Br. 1995;77:830-1.

125. Gasparoni A, Ciardelli L, Avanzini MA, Bonfichi M, di Mario M, Piazzi G, Martinotti L, Vanelli L, Rondini G, Chirico G. Immunophenotypic changes of fetal cord blood hematopoietic progenitor cells during gestation. Pediatr Res. 2000 Jun;47(6):825-9.

126. Gehron Robey P, Fedarko NS, Hefferan TE, Bianco P, Vetter UK, Grze W et al. Structure and molecular regulation of bone matrix proteins. J Bone Miner Res 1993;8:483-7.

127. Georgescu CE, Mihai A, Didilescu AC, Moraru R, Nimigean V, Nimigean VR, Tănase G. Cone beam computed tomography as a method of quantitative and qualitative analysis of alveolar crest in the frontal mandibular area. Rom J Morphol Embryol. 2010;51(4):713-7.

128. Gerson SL. Mesenchymal stem cells: no longer second class marrow citizens. Nat Med. 1999 Mar;5(3):262-4.

129. Gimble JM, Robinson CE, Wu X, Kelly KA. The function of adipocytes in the bone marrow stroma: an update. Bone. 1996;19:421-8.

130. Glowacki J, Kaban LB, Murray JE, Folkman J, Mulliken JB. Application of the biological principle of induced osteogenesis for craniofacial defects. Lancet. 1981 May 2;1(8227):959-62.

131. Goldberg VM, Stevenson S, Shaffer JW, Davy D, Klein L, Zika J, Field G. Biological and physical properties of auto- logous vascularized fibular grafts in dogs. J Bone Joint Surg 1990;72A:801-10.

132. Gómez C, Galán JM, Torrero V, Ferreiro I, Pérez D, Palao R, Martínez E, Llames S, Meana A, Holguín P. Use of an autologous bioengineered composite skin in extensive burns: Clinical and functional outcomes. A multicentric study. Burns. 2011 Jun;37(4):580-9.

133. Gray JC, Elves MW. Donor cells contribution to osteogénesis in experimental 
cancellous bone grafts. Clin Orthop 1982; 163:261-69.

134. Grayson WL, Bunnell BA, Martin E, Frazier T, Hung BP, Gimble JM. Stromal cells and stem cells in clinical bone regeneration. Nat Rev Endocrinol. 2015 Mar;11(3):140-50.

135. Griffith LG, Wu B, Cima MJ, Powers MJ, Chaignaud B, Vacanti JP. In vitro organogénesis of liver tissue. Ann NY Acad Sci. 1997;831:382-97.

136. Groeneveld EH, Burger E H . Bone morphogenetic proteins in human bone regeneration. Eur J Endocrinol 2000; 142: 9-21.

137. Gross U, Strunz V. The interface of various glasses and glass ceramics with a bony implantation bed. J Biomed Mater Res. 1985 Mar;19(3):251-71.

138. Groth T, Altankov G, Kostadinova A, Krasteva N, Albrecht W, Paul D. Altered vitronectin receptor (alphav integrin) function in fibroblasts adhering on hydrophobic glass. J Biomed Mater Res. 1999 Mar 5;44(3):341-51.

139. Gupta DM, Kwan MD, Slater BJ, Wan DC, Longaker MT. Applica- tions of an athymic nude mouse model of nonhealing critical- sized calvarial defects. J Craniofac Surg 2008;19:192-197.

140. Gutierrez-Aranda I, Ramos-Mejia V, Bueno C, Munoz-Lopez M, Real PJ, Mácia A, Sanchez L, Ligero G, Garcia-Parez JL, Menendez P. Human induced pluripotent stem cells develop teratoma more efficiently and faster than human embryonic stem cells regardless the site of injection. Stem Cells. 2010 Sep;28(9):1568-70.

141. Hadjiargyrou M, McLeod K, Ryaby JP, Rubin C. Enhancement of fracture healing by low intensity ultrasound. Clin Orthop Relat Res. 1998 Oct;(355 Suppl):S216-29.

142. Hall B. The embryonic development of bone. Sci Am 1988; 76: 174-81.

143. Hall PA, Watt FM.Stem cells: the generation and maintenance of cellular diversity. 1989 Aug;106(4):619-33.

144. Halvorsen YC, Wilkison WO, Gimble JM. Adipose-derived stromal cellstheir utility and potential in bone formation. Int J Obes Relat Metab Disord. 2000; 24 Suppl 4:S41-4.

145. Ham AW. Some histophysiological problems peculiar to calcified tissue. J Bone Joint Surg Am 1952;34:701.

146. Hao Y, Zhao W, Wang Y, Yu J, Zou D. Assessments of jaw bone density at implant sites using 3D cone-beam computed tomography. Eur Rev Med Pharmacol Sci. 2014;18(9):1398-403.

147. Harada S, Rodan GA. Control of osteoblast function and regulation of bone mass. Nature. 2003 May 15; 423 (6937): 349-55.

148. Harris CT, Cooper LF. Comparison of bone graft matrices for human mesenchymal stem cell-directed osteogenesis. J Biomed Mater Res A 2004;68:747-55.

149. Haynesworth SE, Goshima J, Goldberg VM, Caplan AI. Characterization of cells with osteogenic potential from human marrow. Bone. 1992;13(1):81-8.

150. Healey JH, Zimmerman PA, McDonnell JM, Lane JM. Percutaneous bone 
marrow grafting of delayed union and nonunion in cancer patients. Clin Orthop. 1990;256:280-5.

151. Heersche JNM. Mesenchymal stem cells and their involvement in bone remodeling, repair, and regeneration. En: Zarb G, Leckholm U, Albrektsson T, Tenenbaum H eds. Aging, Osteoporosis, and Dental Implants. Carol Stream: Quintessence Publishing Co.; 2002. p. 17-23.

152. Hennessey JV, Chromiak JA, DellaVentura S, Reinert SE, Puhl J, Kiel DP, Rosen CJ, Vandenburgh H, MacLean DB. Growth hormone administration and exercise effects on muscle fiber type and diameter in moderately frail older people. J Am Geriatr Soc. 2001;49:852-8.

153. Hohlweg-Majert B, Pautke C, Deppe H, Metzger MC, Wagner K, Schulze D. Qualitative and quantitative evaluation of bony structures based on DICOM dataset. J Oral Maxillofac Surg. 2011 Nov;69(11):2763-70.

154. Hollander P y Haltton PV. Biopolymer methods in Tissue Engineering, ed., pg. 11 , Humana Press, 2004.

155. Holly, C.E., Schoichet, M.S., Davies, J.E., "Engineering three-dimensional bone tissue in vitro using biodegradable scaffolds: Investigating initial cellseeding density and culture period” J. Biomed. Mat. Res. 2000; 51:3 376-382.

156. Homolka P, Beer A, Birkfellner W, Nowotny R, Gahleitner A, Tschabitscher $\mathrm{M}$, Bergmann $\mathrm{H}$. Bone mineral density measurement with dental quantitative CT prior to dental implant placement in cadaver mandibles: pilot study. Radiology. 2002 Jul;224(1):247-52.

157. Hornicek FJ, Gebhardt MC, Sorger J1, Mankin HJ. Tumor reconstruction. Orthop Clin North Am 1999; 30:673-84.

158. Hoschi k, Komori T, Ozawa H. Morphological characterization of skeletal cells in Cbfa1-deficient mice. Bone 1999 Dec; 25(6):639-51.

159. Hu J, Qi MC, Zou SJ, Li JH, Luo E. Callus formation enhanced by BMP-7 ex vivo gene therapy during distraction osteogenesis in rats.J Orthop Res. 2007 Feb;25(2):241-51.

160. Huang GJ, Cunha-Cruz J, Rothen M, Spiekerman C, Drangsholt M, Anderson L, Roset GA. A prospective study of clinical outcomes related to third molar removal or retention. Am J Public Health. 2014 Apr;104(4):728-34.

161. Huard C, Moisset PA, Dicaire A, Merly F, Tardif F, Asselin I, Tremblay JP. Transplantation of dermal fibroblasts expressing MyoD1 in mouse muscles. Biochem Biophys Res Commun. 1998;248:648-54.

162. Hutmacher D, Hürzeler MB, Schliephake H. A review of material properties of biodegradable and bioresorbable polymers and devices for GTR and GBR applications. Int J Oral Maxillofac Implants. 1996 Sep-Oct;11(5):667-78.

163. Hutmacher, D.W, "Scaffolds in tissue engineering bone and cartilage", Biomaterials. 2000; 21:24 2529- 2543.

164. Hutmacher, D.W, Scaffolds in tissue engineering bone and cartilage. Biomaterials, 2000; 21:24 2529- 2543.

165. Ilizarov GA. Clinical application of the tension-stress effect for limb lengthening. Clin Orthop Relat Res. 1990 Jan;(250):8-26. 
166. Jackson KA, Majka SM, Wang H, Pocius J, Hartley CJ, Majesky MW, Entman ML, Michael LH, Hirschi KK, Goodell MA. Regeneration of ischemic cardiac muscle and vascular endothelium by adult stem cells. J Clin Invest. 2001 Jun;107(11):1395-402.

167. Jadlowiec JA, Celil AB, Hollinger JO. Bone tissue engineering: recent advances and promising therapeutic agents. Expert Opin Biol Ther. 2003 Jun;3(3):409-23.

168. Jakob M, Démarteau O, Schäfer D, Hintermann B, Dick W, Heberer M, Martin I. Specific growth factors during the expansion and redifferentiation of adult human articular chondrocytes enhance chondrogenesis and cartilaginous tissue formation in vitro. J Cell Biochem. 2001 Mar 26;81(2):368-77.

169. James J, Steijn-Myagkaya GL. Death of osteocytes. Electron microscopy after in vitro ischaemia. J Bone Joint Surg Br. 1986 Aug;68(4):620-4.

170. Jiang X, Gittens SA, Chang Q, Zhang X, Chen C, Zhang Z. The use of tissueengineered bone with human bone morphogenetic protein-4-modified bonemarrow stromal cells in repairing mandibular defects in rabbits. Int J Oral Maxillofac Surg. 2006 Dec;35(12):1133-9.

171. Jiang Y, Jahagirdar BN, Reinhardt RL, Schwartz RE, Keene CD, OrtizGonzalez XR, Reyes M, Lenvik T, Lund T, Blackstad M, Du J, Aldrich S, Lisberg A, Low WC, Largaespada DA, Verfaillie CM. Pluripotency of mesenchymal stem cells derived from adult marrow. Nature. 2002;418:41-9.

172. Jiang Y, Vaessen B, Lenvik T, Blackstad M, Reyes M, Verfaillie CM. Multipotent progenitor cells can be isolated from postnatal murine bone marrow, muscle, and brain. Exp Hematol. 2002 Aug;30(8):896-904.

173. Johner R. Dependence of bone healing on defect size. Helv Chir Acta 1972; 39:409 11 .

174. Jones GT1, Jian XC, Laskin DM. The effect of L-dopa on the healing of a rat mandibular defect . J Oral Maxillofac Surg. 1996 Apr;54(4):470-3.

175. Juliette van den Dolder, Paul H.M. Spauwen, and John A. Jansen. Evaluation of Various Seeding Techniques for Culturing Osteogenic Cells on Titanium Fiber Mesh. Tissue Engineering. April 2003, 9(2): 315-325.

176. Kaban LB, Glowacki J, Murray JE. Repair of experimental mandibular bony defects in rats. Surg Forum. 1979;30:519-21.

177. Kaban LB, Glowacki J. Induced osteogenesis in the repair of experimental mandibular defects in rats. J Dent Res. 1981 Jul;60(7):1356-64.

178. Kadiyala S, Young RG, Thiede MA, Bruder SP. Culture expanded canine mesenchymal stem cells possess osteochondrogenic potential in vivo and in vitro. Cell Transplant. 1997;6:125-34.

179. Kaihara S, Borenstein J, Koka R, Lalan S, Ochoa ER, Ravens M, Pien H,Cunningham B, Vacanti JP. Silicon micromachining to tissue engineer branched vascular channels for liver fabrication. Tissue Eng. 2000;6:105-17.

180. Kale AA, Di Cesare PE. Osteoinductive agents. Basic science and clinical applications. Am J Orthop 1995; 24: 752-761.

181. Kanczler JM, Oreffo RO. Osteogenesis and angiogenesis: the potential for 
engineering bone. Eur Cell Mater 2008;15:100-14.

182. Kang HJ, Kim HS, Zhang SY, Park KW, Cho HJ, Koo BK, Kim YJ, Soo Lee D, Sohn DW, Han KS, Oh BH, Lee MM, Park YB. Effects of intracoronary infusion of peripheral blood stem-cells mobilised with granulocyte-colony stimulating factor on left ventricular systolic function and restenosis after coronary stenting in myocardial infarction: the MAGIC cell randomised clinical trial. Lancet. 2004 Mar 6;363(9411):751-6.

183. Kawai T, Urist Mr. Quantitative Computation Of Induced Heterotopic Bone Formation By An Image Analysis Sistem. Clin Orthop 1988; 233:262-7.

184. Kehat I, Khimovich L, Caspi O, Gepstein A, Shofti R, Arbel G, Huber I, Satin $\mathrm{J}$, Itskovitz-Eldor J, Gepstein L. Electromechanical integration of cardiomyocytes derived from human embryonic stem cells. Nat Biotechnol. 2004 Oct;22(10):1282-9.

185. Khan SN, Cammisa FP Jr, Sandhu HS, Diwan AD, Girardi FP, Lane JM. The biology of bone grafting. J Am Acad Orthop Surg. 2005 Jan-Feb;13(1):77-86.

186. Kim HJ, Park SS, Oh SY, Kim H, Kweon OK, Woo HM, Kim WH. Effect of acellular dermal matrix as a delivery carrier of adipose-derived mesenchymal stem cells on bone regeneration. J Biomed Mater Res B Appl Biomater. 2012 Aug;100(6):1645-53.

187. Kjønniksen I, Nesland JM, Pihl A, Fodstad O. Nude rat model for studying metastasis of human tumor cells to bone and bone marrow. J Natl Cancer Inst. 1990 Mar 7;82(5):408-12.

188. Kjønniksen I, Storeng R, Pihl A, McLemore TL, Fodstad O. A human tumor lung metastasis model in athymic nude rats. Cancer Res. 1989 Sep 15;49(18):5148-52.

189. Klein-Nulend J, Roelofsen J, Sterck JG, Semeins CM, Burger EH. Mechanical loading stimulates the release of transforming growth factor-beta activity by cultured mouse calvariae and periosteal cells. J Cell Physiol. 1995;163:115-9.

190. Kneser, U., Schaefer, D.J., Munder, B., Klemt, C., Andree, C., Stark, G.B. Tissue engineering of bone, Min. Invas. Ther. \& Allied Technol,2002; 11:2, 107-116.

191. Komori T, Yagi h, Nomura S, Yamaguchi A, Sasaki K, Deguchi K, Shimizu Y, Bronson RT, Gao YH, Inada M, Sato M, Okamoto R, Kitamura Y, Yoshiki $\mathrm{S}$, Kishimoto T. Targeneted discruption of Cbfal results in a complete lack of bone formation owing to maturational arrest of osteoblasts. Cell. 1997 May 30; 89(5):755-64.

192. Kopen GC, Prockop DJ, Phinney DG. Marrow stromal cells migrate throughout forebrain and cerebellum, and they differentiate into astrocytes after injection into neonatal mouse brains.Proc Natl Acad Sci U S A. 1999 Sep 14;96(19):10711-6.

193. Körbling M, Estrov Z. Adult stem cells for tissue repair - a new therapeutic concept? N Engl J Med. 2003 Aug 7;349(6):570-82.

194. Kulkarni RK, Pani KC, Neuman C, Leonard F. Polylactic Acid for Surgical Implants. Archives of Surgery 1966; 93(5):839-\&. 
195. Kurz LT1, Garfin SR, Booth RE Jr. Harvesting autogenous iliac bone grafts. A review of complications and techniques. Spine (Phila Pa 1976). 1989 Dec;14(12):1324-31.

196. Lacey DL, Timms E, Tan HL, Kelley MJ, Dunstan CR, Burguess TL et al. Osteoprotegerin ligand is a cytokine that regulates osteoclasts differentiation and activation. Cell 1998;93:165-76.

197. Lagasse E1, Connors H, Al-Dhalimy M, Reitsma M, Dohse M, Osborne L, Wang X, Finegold M, Weissman IL, Grompe M. Purified hematopoietic stem cells can differentiate into hepatocytes in vivo.Nat Med. 2000 Nov;6(11):122934.

198. Lane NE, Sanchez S, Modin GW, Genant HK, Pierini E, Arnaud CD. Parathyroid hormone treatment can reverse corticosteroid-induced osteoporosis. Results of a randomized controlled clinical trial. J Clin Invest. 1998;102:1627-33.

199. Lange, R., Luthen, F., Beck, U., Rychly, Baumann, J., A., Nebe, B., "Cellextracellular matrix interaction and physico-chemical characteristics of titanium surfaces depend on the roughness of the material", Biomol. Eng. 2002; 19:2-6 255-261.

200. Langer, R., Vacanti, J. P., -Tissue Engineering, Science, 1993;260:5110, 920-926.

201. Lanyon L. Osteocytes, strain detection, bone remodeling and remodeling. Calcified Tissue Int 1993;53:102-7.

202. Lasa C, Hollinger J, Drohan W, Macphee M. Dlivery Of Demineralized Bone Power Fibrin Sealant. Plast Reconsr Surg 1995; 96: 1409-18.

203. Laurencin CT, Ferriter PJ, Millis MB. Oblique proximal tibial osteotomy for the correction of tibia vara in the young. Clin Orthop Relat Res. 1996 Jun;(327):218-24.

204. Lee YM, Park YJ, Lee SJ, Ku Y, Han SB, Choi SM, Klokkevold PR, Chung $\mathrm{CP}$. Tissue engineered bone formation using chitosan/tricalcium phosphate sponges. J Periodontol. 2000 Mar;71(3):410-7.

205. Leong, K.F., Cheah, C.M., Chua, C.K. Solid freeform fabrication of threedimensional scaffolds for engineering replacement tissues and organs. Biomaterials. 2003; 24:13 3262-2378.

206. Leri A, Kajstura J, Anversa P. Cardiac stem cells and mechanisms of myocardial regeneration. Physiol Rev. 2005 Oct;85(4):1373-416.

207. Lewandowska K, Balachander N, Sukenik CN, Culp LA. Modulation of fibronectin adhesive functions for fibroblasts and neural cells by chemically derivatized substrata. J Cell Physiol. 1989 Nov;141(2):334-45.

208. Lewandrowski KU, Tomford WW, Schomacker KT, Deutsch TF, Mankin HJ. Improved osteoinduction of cortical bone allograf $\mathrm{s}$ : a study of the effects of laser perforation and partial demineralization. J Orthop Res 1997; 15: 748-756.

209. Liebschner MA. Biomechanical considerations of animal models used in tissue engineering of bone. Biomaterials. 2004 Apr;25(9):1697-714.

210. Lind M, Bünger C. Factors stimulating bone formation. Eur Spine J. 2001 
Oct;10 Suppl 2:S102-9.

211. Logeart-Avramoglou D, Anagnostou F, Bizios R, Petite H. Engineering bone: challenges and obstacles. J Cell Mol Med, 2005; 9: 72-84.

212. Lorente CA, Song BZ, Donoff RB. Healing of bony defects in the irradiated and unirradiated rat mandible. J Oral Maxillofac Surg. 1992 Dec;50(12):13059.

213. Luben RA, Wong GL, Cohn DV. Biochemical characterization with parathormone and calcitonin of isolated bone cells: provi- sional identification of osteoclasts and osteoblasts. Endocrinology 1976; 99: 526-34.

214. Maekawa Y, Anzai T, Yoshikawa T, Sugano Y, Mahara K, Kohno T, Takahashi T, Ogawa S. Effect of granulocyte-macrophage colony-stimulating factor inducer on left ventricular remodeling after acute myocardial infarction. J Am Coll Cardiol. 2004 Oct 6;44(7):1510-20.

215. Mainil-Varlet P, Rieser F, Grogan S, Mueller W, Saager C, Jakob RP. Articular cartilage repair using a tissue-engineered cartilage-like implant: an animal study. Osteoarthritis Cartilage. 2001;9 Suppl A:S6-15.

216. Maiorana C, Beretta M, Battista Grossi G, Santoro F, Scott Herford A, Nagursky $\mathrm{H}$, Cicciù $\mathrm{M}$. Histomorphometric evaluation of anorganic bovine bone coverage to reduce autogenous grafts resorption: preliminary results. Open Dent J. 2011 Apr 25;5:71-8.

217. Majeska RJ, Rodan GA. Culture and activity of osteoblast and osteoblast-like cells. In Butler WT (Ed) The chemistry and bio- logy ofmineralized tissues. Birmingham Ebsco Media, Inc 1985; pg.: 279-8.

218. Majors AK, Boehm CA, Nitto H, Midura RJ, Muschler GF. Characterization of human bone marrow stromal cells with respect to osteoblastic differentiation. J Orthop Res. 1997;15:546-57.

219. Makino S, Fukuda K, Miyoshi S, Konishi F, Kodama H, Pan J, Sano M, Takahashi T, Hori S, Abe H, Hata J, Umezawa A, Ogawa S. Cardiomyocytes can be generated from marrow stromal cells in vitro. J Clin Invest. 1999 Mar;103(5):697-705.

220. Malicev E, Marolt D, Kregar Velikonja N, Kreft ME, Drobnic M, Rode M. Growth and differentiation of alveolar bone cells in tissue-engineered constructs and monolayer cultures. Biotechnol Bioeng 2008;100:773-81.

221. Manolagas, M.D, Ph. D, and Robert L. Jilka, Ph.D. Bone Marrow, Cytokines, and Bone Remodeling. Emerging Insights into the Pathophysiology of Osteoporosis N Engl J Med 1995; 332:305-311.

222. Maquet V. Jerome R. Design of macroporous biodegradable polymer scaffolds for cell transplantation. Mat. Science Forum. 1997; 250, 15- 42.

223. Marks SCJr, Popoff SN. Bone cell biology: the regulation of development, structure and function in the skeleton. Am j Anat 1988;183:1-44.

224. Martin GR. Isolation of a pluripotent cell line from early mouse embryos cultured in medium conditioned by teratocarcinoma stem cells. Proc Natl Acad Sci U S A. 1981 Dec;78(12):7634-8.

225. Masi L, Brandi ML. Physiopathological basis of bone turnover. Q J Nucl Med. 
2001 Mar;45(1):2-6.

226. Mathews, J. Bone estructure and ultrastructure. En: Urist M (ed): Fundamental and Clinical Bone Physiology. Philadelphia: Lippincott, JB, 1980: 4.

227. Mavrakos AE, Iafrati MD, Doleman SE, Klagsbrun M. Growth factors in bone matrix. Isolation of multiple types by affinity chromatography on heparin Sepharose. J Biol Chem. 1986 Sep 25;261(27):12665-74.

228. McKay R. Stem cells, hype and hope. Nature. 2000;406:361-4.

229. McNiece I, Briddell R. Ex vivo expansion of hematopoietic progenitor cells and mature cells. Exp Hematol. 2001;29:3-11.

230. Meana A, García E, García V, Jorcano JL, del Río M, Larcher F, Duarte B, Holguin A. Method for preparing three-dimensional structures for tissue engineering. WO 2008/119855

231. Meijer GJ, de Bruijn JD, Koole R, van Blitterswijk CA. Cell-based bone tissue engineering. PLoS Med. 2007 Feb;4: 260-4.

232. Meyer J. Visualization of osseointegration of maxilla and mandible dental implants. Int J Comput Assist Radiol Surg. 2010 Jan;5(1):69-76.

233. Meyer U, Joos U, Wiesmann HP. Biological and biophysical principles in extracorporal bone tissue engineering. Part I. Int J Oral Maxillofac Surg. 2004 Jun;33(4):325-32.

234. Meyer U, Joos U, Wiesmann HP.Biological and biophysical principles in extracorporal bone tissue engineering. Part III. Int J Oral Maxillofac Surg. 2004 Oct;33(7):635-41.

235. Minamide A, Boden SD, Viggeswarapu M, Hair GA, Oliver C, Titus L. Mechanism of bone formation with gene transfer of the cDNA encoding for the intracellular protein LMP-1. J Bone Joint Surg Am. 2003;85:1030-9.

236. Mohan S, B ayli nk D J. B on e g rowth fac tors . C lin Or t h o p 1991; 30-48.

237. Morrison SJ, Uchida N, Weissman IL. The biology of hematopoietic stem cells. Annu Rev Cell Dev Biol. 1995;11:35-71.

238. Motoki DS, Mulliken, JB. The healing of bone and cartilage. Clin Plast Surg $1990 ; 17: 527-44$.

239. Mulliken JB, Glowacki J, Kaban LB, Folkman J, Murray JE. Use of demineralized allogeneic bone implants for the correction of maxillocraniofacial deformities. Ann Surg 1981; 194: 366-372.

240. Mulliken JB, Glowacki J. Induced osteogenesis for repair and con- struction in the craniofacial region. Plast Reconstr Surg 1980;65: 553-560.

241. Mundy GR. Cytokines and growth factors in the regulation of bone remodeling. J Bone Miner Res 1993;8:505-10.

242. Muschler GF, Boehm C, Easley K. Aspiration to obtain osteoblast progenitor cells from human bone marrow: the influence of aspiration volume. J Bone Joint Surg Am. 1997;79:1699-709. Erratum in: J Bone Joint Surg Am. 1998; 80:302.

243. Muschler GF, Midura RJ, Nakamoto C. Practical modeling concepts for 
connective tissue stem cell and progenitor compartment kinetics. J Biomed Biotechnol. 2003;2003:170-93.

244. Muschler GF, Midura RJ. Connective tissue progenitors: practical concepts for clinical applications. Clin Orthop. 2002;395:66-80.

245. Muschler GF, Nakamoto C, Griffith LG. Engineering principles of clinical cell-based tissue engineering. J Bone Joint Surg Am. 2004 Jul;86-A(7):154158.

246. Muschler GF, Nitto H, Boehm CA, Easley KA. Age- and gender-related changes in the cellularity of human bone marrow and the prevalence of osteoblastic progenitors. J Orthop Res. 2001;19:117-25.

247. Muschler GF, Nitto H, Matsukura Y, Boehm C, Valdevit A, Kambic H, Davros W, Powell K, Easley K. Spine fusion using cell matrix composites enriched in bone marrow-derived cells. Clin Orthop. 2003;407:102-18.

248. Muschler GF1, Nakamoto C, Griffith LG. Engineering principles of clinical cell-based tissue engineering. J Bone Joint Surg Am. 2004 Jul;86-A(7):154158.

249. Nijweide PJ, Van Iperen-van Gent AS, Kawilarang-de Haas EWM, Van der Plas A, Wassenaar AM. Bone formation and calcification by isolated osteoblastlike cells. J Cell Biol 1982; 93: 318-23.

250. O’Driscoll SW. Articular cartilage regeneration using periosteum. Clin Orthop. 1999;367 Suppl:S186-203.

251. Odorico JS, Kaufman DS, Thomson JA. Multilineage differentiation from human embryonic stem cell lines. Stem Cells. 2001;19(3):193-204.

252. Ogawa M. Changing phenotypes of hematopoietic stem cells. Exp Hematol. 2002 Jan;30(1):3-6.

253. Orlic D, Kajstura J, Chimenti S, Limana F, Jakoniuk I, Quaini F, Nadal-Ginard B, Bodine DM, Leri A, Anversa P. Mobilized bone marrow cells repair the infarcted heart, improving function and survival. Proc Natl Acad Sci U S A. 2001 Aug 28;98(18):10344-9.

254. Ortiz Cruz EJ, Campo Loarte J, Martínez Marín, Canosa Sevillano R. Estructura y organización de un banco de hue- sos y tejidos. Rev Ortop Traumatol 2000; 44:127-38.

255. Owen M, Friedenstein AJ. Stromal stem cells: marrow-derived osteogenic precursors. Ciba Found Symp. 1988;136:42-60.

256. Parfitt AM. Bone remodeling: relationship to the amount and structure of bone, and the pathogenesis and prevention of fractrues. En: Riggs BL, Melton LJ (eds): Osteoporosis: etiology, diagnosis and management. New York: Raven Press, 1993.

257. Parikh SN. Gene therapy: principles and clinical applications in orthopedics. Orthopedics. 2004;27:294-305.

258. Peck WA, Birge, S.I, Fedak SA. Bone cells: biochemical and biological studies after enzymatic isolation. Science 1964; 146: 147.

259. Pera MF1, Reubinoff B, Trounson A. Human embryonic stem cells. J Cell Sci. 
2000 Jan;113 ( Pt 1):5-10.

260.Peterson B, Zhang J, Iglesias R, Kabo M, Hedrick M, Benhaim P, Lieberman JR. Healing of critically sized femoral defects, using genetically modified mesenchymal stem cells from human adipose tissue. Tissue Eng. 2005 JanFeb;11(1-2):120-9.

261. Pittenger MF, Mackay AM, Beck SC, Jaiswal RK, Douglas R, Mosca JD, Moorman MA, Simonetti DW, Craig S, Marshak DR. Multilineage potential of adult human mesenchymal stem cells. Science. 1999 Apr 2;284(5411):143-7.

262. Pittenger MF, Mosca JD, McIntosh KR. Human mesenchymal stem cells: progenitor cells for cartilage, bone, fat and stroma. Curr Top Microbiol Immunol. 2000;251:3-11.

263. Prêle CM, Horton MA, Caterina P, Stenbeck G. Identification of the molecular mechanisms contributing to polarized trafficking in osteoblasts. Exp Cell Res. 2003 Jan 1;282(1):24-34.

264. Prockop DJ. Marrow stromal cells as stem cells for nonhematopoietic tissues. Science. 1997;276:71-4.

265. Prósper F, Verfaillie CM. Adult stem cells. An Sist Sanit Navar. 2003 SepDec;26(3):345-56.

266. Reddi AH. Bone morphogenetic proteins: an unconven- tional approach to isolation of first mammalian mor- phogens. Cytokine Growth Factor Rev 1997; 8: $11-20$.

267. Redondo LM, Sánchez A. Regeneración de cavidades óseas quísticas de 1ls maxilares mediante bioimplante de células MSV-H asociadas a matriz de suero entrecruzada (BIOMAX-VA-2010).

268. Reyes M, Verfaillie CM. Characterization of multipotent adult progenitor cells, a subpopulation of mesenchymal stem cells. Ann NY Acad Sci. 2001; 938:231-5.

269. Richardson JB, Gardner TN, Hardy JR, Evans M, Kuiper JH, Kenwright J. Dynamisation of tibial fractures. J Bone Joint Surg Br. 1995 May;77(3):412-6.

270. Ringe J, Kaps C, Burmester GR, Sittinger M. Stem cells for regenerative medicine: advances in the engineering of tissues and organs. Naturwissenschaften. 2002;89:338-51.

271. Robey PG. Stem cells near the century mark. J Clin Invest. 2000 Jun;105(11):1489-91.

272. Rosset, A. Informatics in radiology (infoRAD): navigating the fifth dimension: innovative interface for multidimensional multimodality image navigation. Radiographics, 2006; 26(1): p. 299-308.

273. Rosset, A., L. Spadola, and O. Ratib, OsiriX: an open-source software for navigating in multidimensional DICOM images. J Digit Imaging, 2004; 17(3): p. 205-16.

274. Rosset, C., A. Rosset, and O. Ratib, General consumer communication tools for improved image management and communication in medicine. J Digit Imaging, 2005; 18(4): p. 270-9. 
275. Rossignoli F1, Caselli A, Grisendi G, Piccinno S, Burns JS, Murgia A, Veronesi E, Loschi P, Masini C, Conte P, Paolucci P, Horwiz EM, Dominici $\mathrm{M}$. Isolation, characterization, and transduction of endometrial decidual tissue multipotent mesenchymal stromal/stem cells from menstrual blood. Biomed Res Int. 2013;2013:901821.

276. Rubin C, Bolander M, Ryaby JP, Hadjiargyrou M. The use of low-intensity ultrasound to accelerate the healing of fractures. J Bone Joint Surg Am. 2001;83:259-70.

277. Rutenberg MS, Hamazaki T, Singh AM, Terada N. Stem cell plasticity, beyond alchemy. Int J Hematol. 2004 Jan;79(1):15-21.

278. Ryaby JT. Clinical effects of electromagnetic and electric fields on fracture healing. Clin Orthop Relat Res. 1998 Oct;(355 Suppl):S205-15.

279. Rygaard, T., Brünner, N., Groen, N. and Spang-Thompson, M. (Eds). (1987). Immune-deficient animals in biomedical research. Basel:Karger.

280. Salak R, Fox CF. Tissue engineering. Granlibakken, Lake Tahoe. Proc workshop; New York: liss; 1988.

281. Salem HK, Thiemermann C Mesenchymal stromal cells: current understanding and clinical status..Stem Cells. 2010 Mar 31;28(3):585-96. doi: 10.1002/stem.269.

282. Salgado AJ1, Coutinho OP, Reis RL. Bone tissue engineering: state of the art and future trends. Macromol Biosci. 2004 Aug 9;4(8):743-65.

283. San Roman J, Sanchez P, Villa A, Sanz-Ruíz R, Fernández-Santos ME, Gimeno F, Ramos B, Arnold R. Comparison of Different Bone MarrowDerived Stem Cell Approaches in Reperfused STEMI. A Multicenter, Prospective, Randomized,Open-Labeled TECAM Trial. JACC. 2015. Vol 65 $n^{\circ}$ 22; 2372-2382

284. Sanchez JF, Crooks DR, Lee CT, Schoen CJ, Amable R, Zeng X, FlorivalVictor T, Morales N, Truckenmiller ME, Smith DR, Freed WJ. GABAergic lineage differentiation of AF5 neural progenitor cells in vitro. Cell Tissue Res. 2006 Apr;324(1):1-8.

285. Sánchez PL, San Román JA, Villa A, Fernández ME, Fernández-Avilés F. Contemplating the bright future of stem cell therapy for cardiovascular disease. Nat Clin Pract Cardiovasc Med. 2006 Mar;3 Suppl 1:S138-51.

286. Sánchez-Ramos J, Song S, Cardozo-Pelaez F, Hazzi C, Stedeford T, Willing A, Freeman TB, Saporta S, Janssen W, Patel N, Cooper DR, Sanberg PR. Adult bone marrow stromal cells differentiate into neural cells in vitro. Exp Neurol. 2000 Aug;164(2):247-56.

287. Sarawar SR, Yang CP, Bell EB. T-cell receptor-bearing cells from athymic nude rats respond to alloantigen in vitro but are defective in vivo. Immunology. $1991 \mathrm{Jul} ; 73(3): 334-41$.

288. Sauer, L.A., Dauchy, R.T., Blask, D.E., Krause, J.A., Davidson, L.K. and Dauchy, E.M. (2005). Eicosapentaenoic acid suppresses cell proliferation in MCF-7 human breast cancer xenografts in nude rats via a pertussis toxinsensitive signal transduction pathway. J. Nutr., 135, 2124-9. 
289. Schenk RK. Biology of fractrue repari. En: Browner BD, Jupiter JB, Levine AM, Traften PG (eds): Skeletal Trauma.Philadelphia: Saunders, 1992: 31.

290. Schmitz JP, Hollinger JO. A simple instrument for achieving accurate alignment and pre-insertion stability with mandibular bone plates. Plast Reconstr Surg. 1986 Dec;78(6):822-3.

291. Schmitz JP, Hollinger JO. The critical size defect as an experimental model for craniomandibulofacial nonunions. Clin Orthop Relat Res. 1986 Apr;(205):299-308.

292. Schmitz JP, Schwartz Z, Hollinger JO, Boyan BD. Characterization of rat calvarial nonunion defects.Acta Anat (Basel). 1990;138(3):185-92.

293. Schonau E, Rauch F. Markers of bone and collagen metabolism. Problems and perspectives in Pediatrics. Horm Res 1997;48:50-9.

294. Schönherr E, Hausser HJ. Extracellular matrix and cytokines: a functional unit. 2000; Dev Immunol 7(2-4):89-101.

295. Shadjou N, Hasanzadeh M. Bone tissue engineering using silica-based mesoporous nanobiomaterials:Recent progress. Mater Sci Eng C Mater Biol Appl. 2015 Oct 1;55:401-9.

296. Shamblott MJ, Axelman J, Wang S, Bugg EM, Littlefield JW, Donovan PJ, Blumenthal PD, Huggins GR, Gearhart JD. Derivation of pluripotent stem cells from cultured human primordial germ cells. Proc Natl Acad Sci U S A. 1998 Nov 10;95(23):13726-31.

297. Shamaz BH, Anitha A, Vijayamohan M, Kuttappan S, Nair S, Nair MB. Relevance of fiber integrated gelatin-nanohydroxyapatite composite scaffold for bone tissue regeneration. Nanotechnology. 2015 Sep 16;26(40):405101.

298. Shima WN, Ali AM, Subramani T, Mohamed Alitheen NB, Hamid M, Samsudin AR, Yeap SK. Rapid growth and osteogenic differentiation of mesenchymal stem cells isolated from human bone marrow. Exp Ther Med. 2015 Jun;9(6):2202-2206.

299. Siegall, C. B., Liggitt, D., Chace, D., Tepper, M. A., and Fell, H. P. (1994). Prevention of immunotoxin-mediated vascular leak syndrome in rats with retention of antitumor activity. PNAS, 91, 9514-9518.

300. Silva GV, Litovsky S, Assad JA, Sousa AL, Martin BJ, Vela D, Coulter SC, Lin J, Ober J, Vaughn WK, Branco RV, Oliveira EM, He R, Geng YJ, Willerson JT, Perin EC. Mesenchymal stem cells differentiate into an endothelial phenotype, enhance vascular density, and improve heart function in a canine chronic ischemia model. Circulation. 2005 Jan 18;111(2):150-6.

301. Simmons DJ. Fracture healing perpectives. Clin Orthop 1985; 200:100-13.

302. Spector M. Biomaterials-based tissue engineering and regenerative medicine solutions to musculoskeletal problems. Swiss Med Wkly. 2006; 136(1920):293-301.

303. Stamm C, Westphal B, Kleine HD, Petzsch M, Kittner C, Klinge H, Schümichen C, Nienaber CA, Freund M, Steinhoff G. Autologous bonemarrow stem-cell transplantation for myocardial regeneration. Lancet. 2003 Jan 4;361(9351):45-6. 
304. Stevenson S. Biology of bone grafts. Orthop Clin Nort Am 1999;30:543-52.

305. Storeng RT, Kjønniksen I, Pihl A, Haug E, Fodstad O. Athymic rats in preclinical immunodiagnostic studies. Anticancer Res. 1991 MarApr;11(2):649-55.

306. Suckow, M.A., Weisbroth, S.H. and Franklin, C.L. (2006). (Eds). The Laboratory Rat. Amsterdam: Elsevier.

307. Svechnikova, I., Gray, S.G., Kundrotiene, J., Ponthan, F., Kogner, P. and Ekstrom, T.J. (2003). Apoptosis and tumor remission in liver tumor xenografts by 4-phenylbutyrate. Intl. J. Oncol., 22, 579-88.

308. Takagi K, Urist MR. The role of bone marrow in bone morphogenetic proteininduced repair of femoral massive diaphyseal defects. Ann Surg. 1982 Jul;196(1):100-9.

309. Takahashi K, Tanabe K, Ohnuki M, Narita M, Ichisaka T, Tomoda K, Yamanaka S. Induction of pluripotent stem cells from adult human fibroblasts by defined factors. Cell. 2007 Nov 30;131(5):861-72.

310. Taylor GI. Reconstructive surgery of facial bones. Part 1: Free composite osteocutaneous grafts for jaw reconstruction. Stark RB 8ed): Plastic surgery of the head and neck. Churchill, Livingstone, 1987;1109.

311. Tiyapatanaputi P, Rubery PT, Carmouche J, Schwarz EM, O'keefe RJ, Zhang X. A novel murine segmental femoral graft model. J Orthop Res. 2004 Nov;22(6):1254-60.

312. Tomita S, Li RK, Weisel RD, Mickle DA, Kim EJ, Sakai T, Jia ZQ. Autologous transplantation of bone marrow cells improves damaged heart function. Circulation. 1999 Nov 9;100(19 Suppl):II247-56.

313. Trabanelli S, La Manna F, Romano M, Salvestrini V, Cavo M, Ciciarello M, Lemoli RM, Curti A. The Human Mesenchymal Stromal Cell-Derived Osteocyte Capacity to Modulate Dendritic Cell Functions Is Strictly Dependent on the Culture System. J Immunol Res. 2015;2015:526195.

314. Tsai M, Tam SY, Wedemeyer J, Galli SJ. Mast cells derived from embryonic stem cells: a model system for studying the effects of genetic manipulations on mast cell development, phenotype, and function in vitro and in vivo.Int $\mathrm{J}$ Hematol. 2002 May;75(4):345-9.

315. Tsuruga E, Takita H, Itoh H, Wakisaka Y, Kuboki Y. Pore size of porous hydroxyapatite as the cell-substratum controls BMP-induced osteogenesis.J Biochem. 1997 Feb;121(2):317-24.

316. Turkyilmaz I, Tözüm TF, Tumer C. Bone density assessments of oral implant sites using computerized tomography. J Oral Rehabil. 2007 Apr;34(4):267-72.

317. Turner CH, Owan I, Alvey T, Hulman J, Hock JM. Recruitment and proliferative responses of osteoblasts after mechanical loading in vivo determined using sustained-release bromodeoxyuridine. Bone. 1998;22:463-9.

318. Uitto J, Olsen DR, Fazio MJ (1989) Extracellular matrix of the skin: 50 years of progress. J Invest Dermatol 92(4 Suppl):61S-77S.

319. Uludag H, D'Augusta D, Golden J, Li J, Timony G, Riedel R, Wozney JM. Implantation of recombinant human bone morphogenetic proteins with 
biomaterial carriers: A correlation between protein pharmacokinetics and osteoinduction in the rat ectopic model. J Biomed Mater Res. 2000 May;50(2):227-38.

320. Urist MR, Lietze A, Mizutani H, Takagi K, Triffitt JT, Amstutz J, DeLange R, Termine J, Finerman GA.A bovine low molecular weight bone morphogenetic protein (BMP) fraction. Clin Orthop Relat Res. 1982 Jan-Feb;(162):219-32.

321.-Urist MR. Bone-Formation by autoinduction. Science 1965;150:893-9.

322. Verfaillie CM. Adult stem cells: assessing the case for pluripotency. Trends Cell Biol. 2002 Nov;12(11):502-8.

323. Viggeswarapu M, Boden SD, Liu Y, Hair GA, Louis-Ugbo J, Murakami H, Kim HS, Mayr MT, Hutton WC, Titus L. Adenoviral delivery of LIM mineralization protein-1 induces new-bone formation in vitro and in vivo. $\mathrm{J}$ Bone Joint Surg Am. 2001;83:364-76.

324. Vos, JG, Kreeftenberg, JG, Kruut, BC, Kruizinga, W, Steerenberg, P. The athymic nude rat: II. Immunological characteristics. Clinical Immunology and Immunopathology. 1980; 15, 229-37.

325. Wagers AJ, Weissman IL. Plasticity of adult stem cells. Cell. 2004 Mar 5;116(5):639-48.

326. Wagner M, Kiapur N, Wiedmann-Al-Ahmad M, Hübner U, Al-Ahmad A, SchönR, Schmelzeisen R, Mülhaupt R, Gellrich NC. Comparative in vitro study of the cell proliferation of ovine and human osteoblast-like cells on conventionally and rapid prototyping produced scaffolds tailored for application as potential bone replacement material. J Biomed Mater Res A 2007;83:1154-64.

327. Wagner W, Wein F, Seckinger A, Frankhauser M, Wirkner U, Krause U, Blake J, Schwager C, Eckstein V, Ansorge W, Ho AD. Comparative characteristics of mesenchymal stem cells from human bone marrow, adipose tissue, and umbilical cord blood. Exp Hematol. 2005 Nov;33(11):1402-16.

328. Wakitani S, Saito T, Caplan AI. Myogenic cells derived from rat bone marrow mesenchymal stem cells exposed to 5-azacytidine. Muscle Nerve. 1995 Dec;18(12):1417-26.

329. Wang JS, Shum-Tim D, Galipeau J, Chedrawy E, Eliopoulos N, Chiu RC. Marrow stromal cells for cellular cardiomyoplasty: feasibility and potential clinical advantages. J Thorac Cardiovasc Surg. 2000 Nov;120(5):999-1005.

330. Weissman IL. Translating stem and progenitor cell biology to the clinic: barriers and opportunities. Science. 2000 Feb 25;287(5457):1442-6.

331. Whang PG, Wang JC. Bone grafs substitutes for spinal fusión. Spine J. 2003 Mar Apr;3(2):155-65.

332. Whitson SW, Harrison W, Dunlap MK, Bowers DE, Fisher LW, Gheron RP. Fetal bovine cells synthesize bone-spe- cific matrix proteins. J Cell Biol Med 1984; 99: 318-23.

333. Williams DC, Boder GB, Toomey RE, Paul DC, Hillman CC, King KL. Mineralization and metabolic response in se- rially passaged adult, rat bone cells. Calcif Tissue Int 1980; 30: 233-46. 
334. Winter A, Breit S, Parsch D, Benz K, Steck E, Hauner H, Weber RM, Ewerbeck V, Richter W. Cartilage-like gene expression in differentiated human stem cell spheroids: a comparison of bone marrow-derived and adipose tissue-derived stromal cells. Arthritis Rheum. 2003;48:418-29.

335. Yamaguchi A, Komori T, Sud T. Regulation of osteoblast differentation mediated by bone morphogenetic proteins, hedgehogs and Cbfa1. Endocr Rev. 2000 Aug;21(4):393-411.

336. Yamanaka S, Takahashi K. Induction of pluripotent stem cells from mouse fibroblast cultures. Tanpakushitsu Kakusan Koso. 2006 Dec;51(15):2346-51.

337. Yang S, Leong KF, Du Z, Chua CK. The design of scaffolds for use in tissue engineering. Part I. Traditional factors. Tissue Eng. 2001 Dec;7(6):679-89.

338. Yim EK, Reano RM, Pang SW, Yee AF, Chen CS, Leong KW. Nanopatterninduced changes in morphology and motility of smooth muscle cells. Biomaterials 2005; 26(26):5405-5413.

339. Yoon E, Dhar S, Chun DE, Gharibjanian NA, Evans GR. In vivo osteogenic potential of human adipose-derived stem cells/poly lactide-co-glycolic acid constructs for bone regeneration in a rat critical-sized calvarial defect model. Tissue Eng. 2007 Mar;13(3):619-27.

340. Yoon ST, Boden SD. Osteoinductive molecules in orthopaedics: basic science and preclinical studies. Clin Orthop Relat Res. 2002 Feb;(395):33-43.

341. Younger EM, Chapman MW. Morbidity at bone graft donor sites. J Orthop Traum 1989; 3:192-5.

342. Zadpoor AA. Bone tissue regeneration: the role of scaffold geometry. Biomater Sci. 2015 Feb 20;3(2):231-45.

343. Zeng H, Chittur KK, Lacefield WR. Analysis of bovine serum albumin adsorption on calcium phosphate and titanium surfaces. Biomaterials. 1999 Feb;20(4):377-84.

344. Zhang S, Prabhakaran MP, Qin X, Ramakrishna S. Biocomposite scaffolds for bone regeneration: Role of chitosan and hydroxyapatite within poly-3hydroxybutyrate-co-3-hydroxyvalerate on mechanical properties and in vitro evaluation. J Mech Behav Biomed Mater. 2015 Jul 15;51:88-98.

345. Zuk PA, Zhu M, Ashjian P, De Ugarte DA, Huang JI, Mizuno H, Alfonso ZC, Fraser JK, Benhaim P, Hedrick MH. Human adipose tissue is a source of multipotent stem cells. Mol Biol Cell. 2002 Dec;13(12):4279-95.

346. Zuk PA, Zhu M, Mizuno H, Huang J, Futrell JW, Katz AJ, Benhaim P, Lorenz HP, Hedrick MH. Multilineage cells from human adipose tissue: implications for cell-based therapies. Tissue Eng. 2001;7:211-28. 